ESRI

SURVEY AND

STATISTICAL

REPORT SERIES

NUMBER 107

September 2021

\section{IDENTIFICATION OF SKILS GAPS AMONG PERSONS WITH DISABILITIES AND THEIR EMPLOYMENT PROSPECTS}

\section{Elish Kelly and Bertrand Maître}

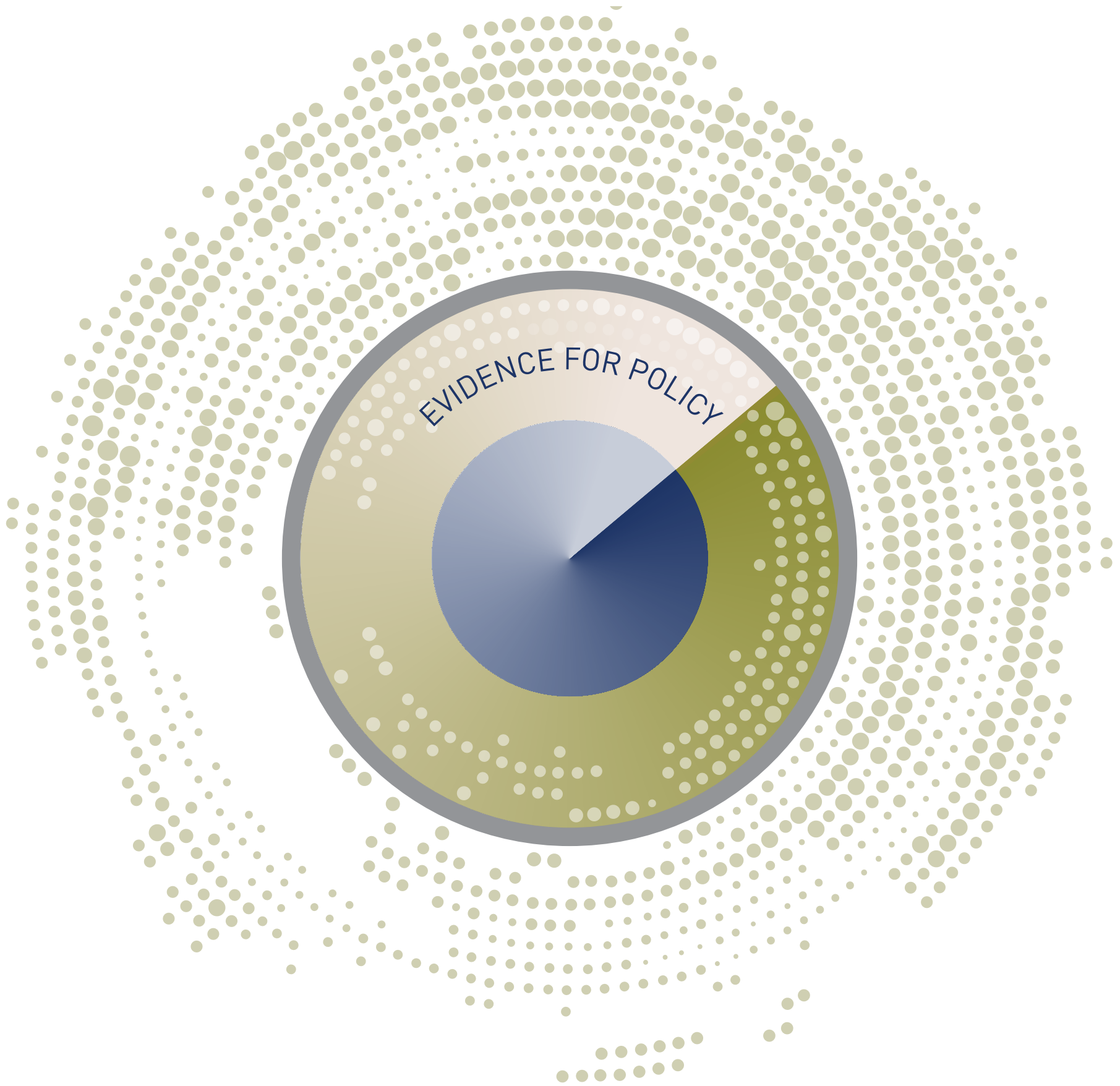




\section{IDENTIFICATION OF SKILLS GAPS \\ AMONG PERSONS WITH DISABILITIES \\ AND THEIR EMPLOYMENT PROSPECTS}

Elish Kelly

Bertrand Maître

September 2021

ESRI SURVEY AND STATISTICAL REPORT SERIES NUMBER 107

Available to download from www.esri.ie

(C) The Economic and Social Research Institute

Whitaker Square, Sir John Rogerson's Quay, Dublin 2

https://doi.org/10.26504/sustat107

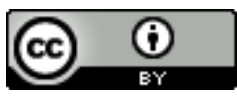

This Open Access work is licensed under a Creative Commons Attribution 4.0 International License (https://creativecommons.org/licenses/by/4.0/), which permits unrestricted use, distribution, and reproduction in any medium, provided the original work is properly credited. 


\section{ABOUT THE ESRI}

The mission of the Economic and Social Research Institute (ESRI) is to advance evidence-based policymaking that supports economic sustainability and social progress in Ireland. ESRI researchers apply the highest standards of academic excellence to challenges facing policymakers, focusing on 12 areas of critical importance to 21st Century Ireland.

The Institute was founded in 1960 by a group of senior civil servants led by Dr T. K. Whitaker, who identified the need for independent and in-depth research analysis to provide a robust evidence base for policymaking in Ireland.

Since then, the Institute has remained committed to independent research and its work is free of any expressed ideology or political position. The Institute publishes all research reaching the appropriate academic standard, irrespective of its findings or who funds the research.

The quality of its research output is guaranteed by a rigorous peer review process. ESRI researchers are experts in their fields and are committed to producing work that meets the highest academic standards and practices.

The work of the Institute is disseminated widely in books, journal articles and reports. ESRI publications are available to download, free of charge, from its website. Additionally, ESRI staff communicate research findings at regular conferences and seminars.

The ESRI is a company limited by guarantee, answerable to its members and governed by a Council, comprising 14 members who represent a cross-section of ESRI members from academia, civil services, state agencies, businesses and civil society. The Institute receives an annual grant-in-aid from the Department of Public Expenditure and Reform to support the scientific and public interest elements of the Institute's activities; the grant accounted for an average of 30 per cent of the Institute's income over the lifetime of the last Research Strategy. The remaining funding comes from research programmes supported by government departments and agencies, public bodies and competitive research programmes.

Further information is available at www.esri.ie 


\section{THE AUTHORS}

Elish Kelly is a Senior Research Officer at the ESRI, an Adjunct Associate Professor at Trinity College Dublin (TCD) and is a Research Fellow at the Institute of Labor Economics (IZA) in the University of Bonn. Bertrand Maître is a Senior Research Officer at the Economic and Social Research Institute (ESRI) and an Adjunct Associate Professor at Trinity College Dublin (TCD).

\section{ACKNOWLEDGEMENTS}

The research undertaken in this report was funded by the National Disability Authority (NDA) as part of its Disability Research Programme with the ESRI. We would like to thank those individuals within the NDA who provided support and assistance during the project, including reviewing earlier drafts of the research. In particular, David Hallinan, Rosalyn Tamming and Aideen Hartney. We are also grateful to Deirdre Lynch, Jim Dalton, and Eva O'Regan from the Central Statistics Office (CSO) for providing Research Microdata Files (RMFs) for the analyses carried out in this study, along with addressing our data queries during the research process. Thanks is extended to the OECD and Eurostat for providing us with access to the PIAAC and EU-SILC 2018 data. ${ }^{1}$ We are also grateful to our colleagues Selina McCoy and Seán Lyons for their useful reviews and comments on earlier drafts of the report. Finally, our thanks go to Alan Barrett, Director of the ESRI, Helen Russell, Head of the Social Research Division within the ESRI, Peter May, Member of the Disability Research Programme Steering Group, and to the independent peerreviewer for their useful reviews of the report.

This report has been accepted for publication by the Institute, which does not itself take institutional policy positions. The report has been peer reviewed prior to publication. The authors are solely responsible for the content and the views expressed. The views and opinions expressed in this publication remain those of the authors and do not represent the views or opinions of the National Disability Authority. 



\section{TABLE OF CONTENTS}

EXECUTIVE SUMMARY

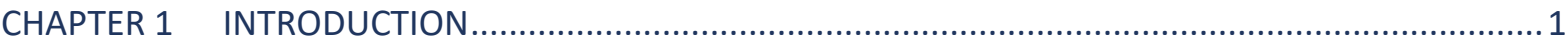

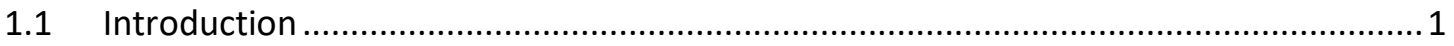

1.2 Educational change .................................................................................. 1

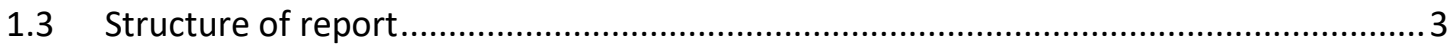

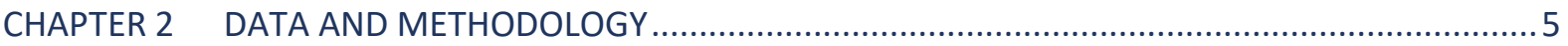

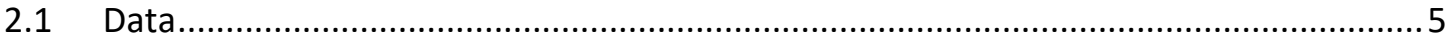

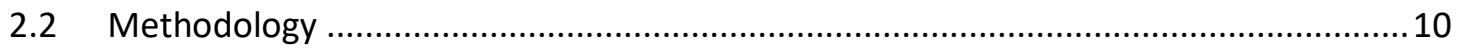

CHAPTER 3 SURVEY ON INCOME AND LIVING CONDITIONS (SILC): 2004, 2011 AND 2019 ............11

3.1 Introduction .......................................................................................... 11

3.2 Socio-demographic characteristics............................................................. 11

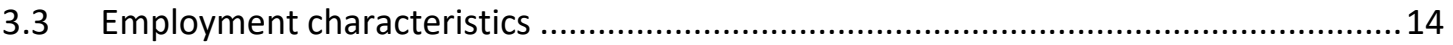

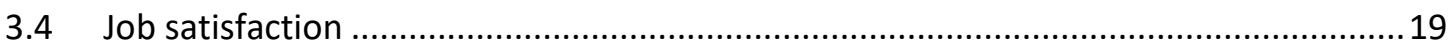

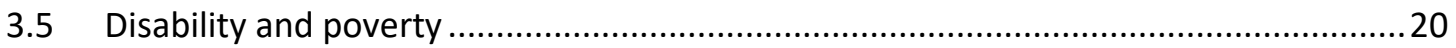

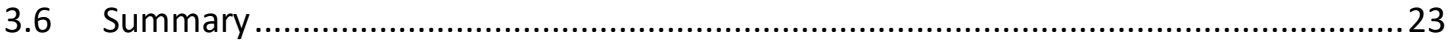

CHAPTER 4 PROGRAMME FOR THE INTERNATIONAL ASSESSMENT OF ADULT

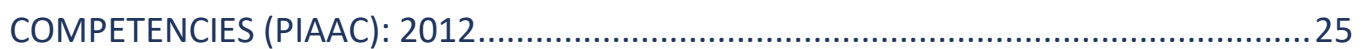

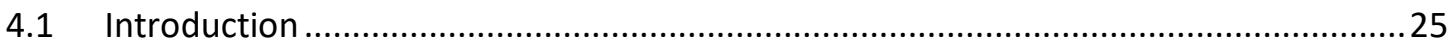

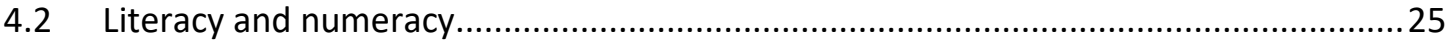

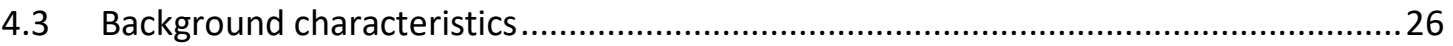

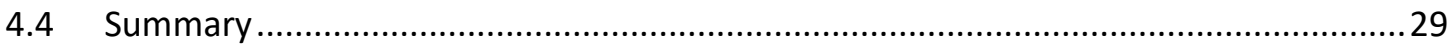

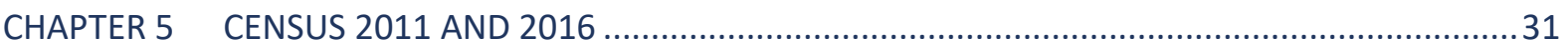

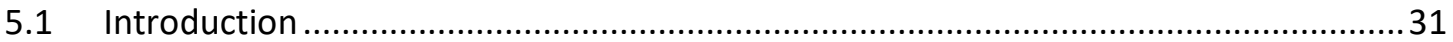

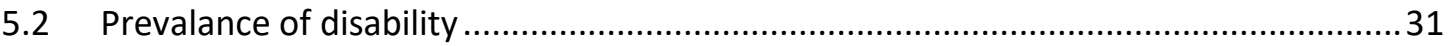

5.3 Demographic profile ................................................................................ 35

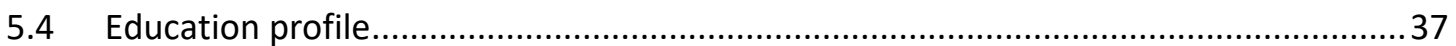

5.5 Computer and internet access.................................................................. 42

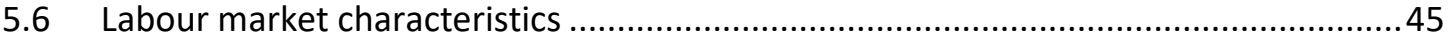

5.7 Impact of disability on likelihood of being an employee .......................................53

5.8 Impact of disability on probability of self-employment .........................................59

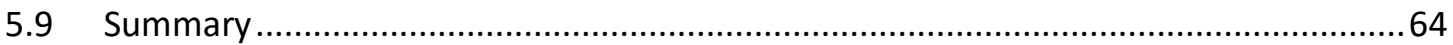


vi I Identification of skills gaps among persons with disabilities and their employment prospects

CHAPTER 6 EUROPEAN UNION STATISTICS ON INCOME AND LIVING CONDITIONS (EUSILC): 2018 .67

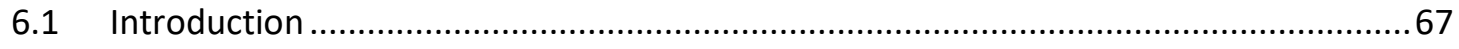

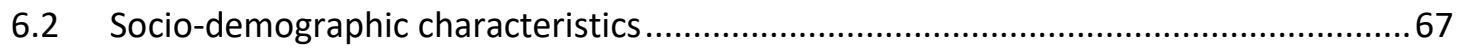

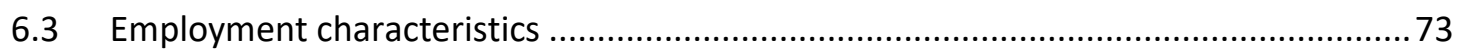

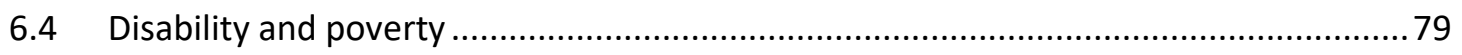

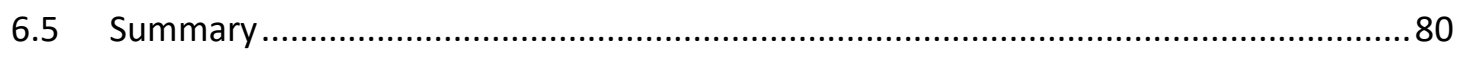

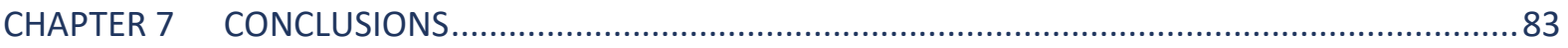

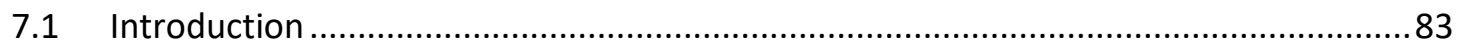

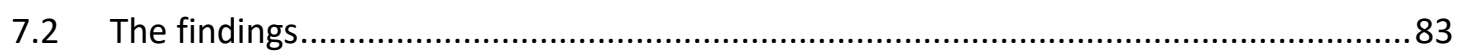

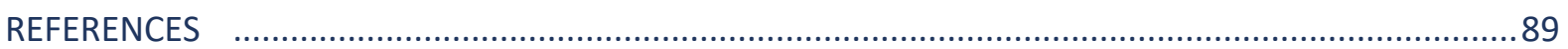

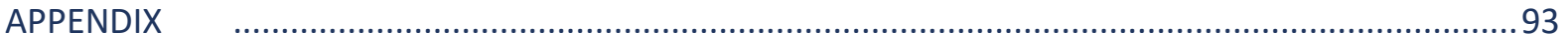




\section{LIST OF TABLES}

Table 2.1 Prevalence of disability among working age population (15-64 years of age) (\%)

Table 2.2 Prevalence of disability among working age population (15-64 years of age): type (\%)

Table 2.3 Prevalence of everyday difficulties among those with disabilities of working age (15-64 years of age): 2011 and 2016 (\%). 6

Table 4.1 Literacy and numeracy skills of working age adults in Ireland (average score): 2012.

Table 4.2 Personal characteristics of working age people with and without a permanent disability in Ireland: 2012 (\%)

Table 4.3 Education profile of people with and without a permanent disability in Ireland: $2012(\%)$

Table 4.4 Employment status of people with and without a permanent disability in Ireland: 2012 (\%)

Table 5.1

Prevalence of disability among working age population (15-64 years of age) (\%) ......32

Table 5.2 Prevalence of everyday difficulties among those with disabilities of working age (15-64 years of age): 2011 and 2016 (\%)...................................................................

Table 5.3 Number of disabilities among people with a disability: 2011 and 2016 (\%) ................33

Table 5.4 Prevalence of secondary disabilities by disability type group: 2011 and 2016 (\%)

Table 5.5 Number of disabilities by everyday difficulties: 2011 and 2016 (\%) ................................ 35

Table 5.6 Demographic profile of people with and without disabilities: 2016 (\%)........................36

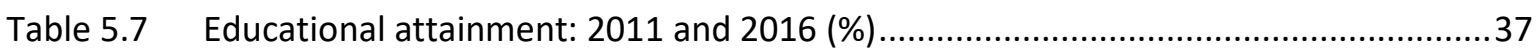

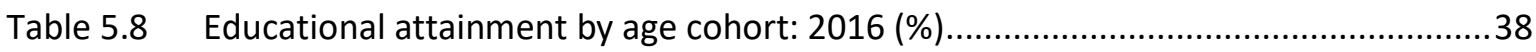

Table 5.9 Educational attainment by disability type: 2011 and 2016 (\%) ....................................39

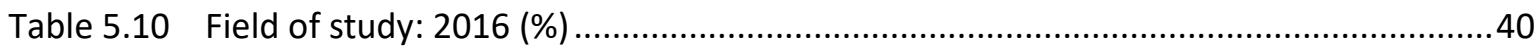

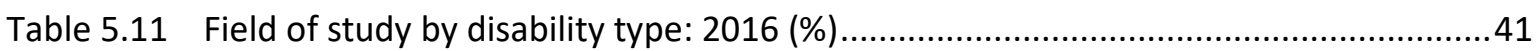

Table 5.12 Personal computer (PC) usage and internet access: 2016 (\%) ...................................42

Table 5.13 Personal computer (PC) usage and internet access by age cohort: 2016 (\%) ..............43

Table 5.14 Personal computer (PC) and internet access by disability type: 2016 (\%) ...................44

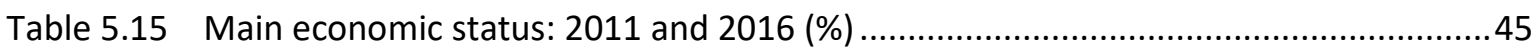

Table 5.16 Main economic status by disability type: 2011 and 2016 (\%)......................................46

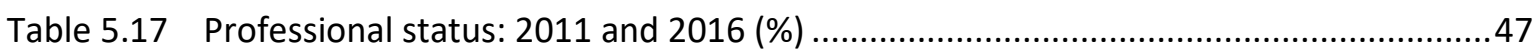

Table 5.18 Professional status by disability type: 2011 and 2016 (\%) .......................................... 48

Table 5.19 Occupational distribution: 2011 and 2016 (\%)......................................................... 49

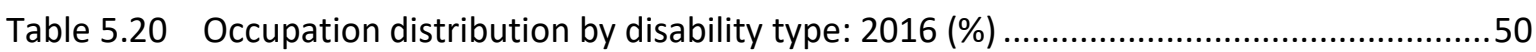

Table 5.21 Economic sector of employment: 2011 and 2016 (\%) ...............................................51

Table 5.22 Economic sector of employment by disability type: 2016 (\%) .......................................52

Table 5.23 Impact of disability on a person's probability of being an employee: 2016

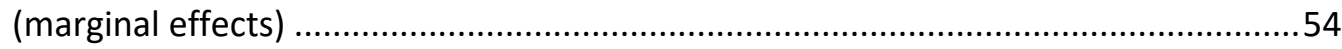

Table 5.24 Impact of disability on a person's probability of being an employee by gender: 2016 (marginal effects) .... 
Table 5.25 Impact of disability type on a person's probability of being an employee: 2016 (marginal effects)

Table 5.26 Impact of disability type on a person's probability of being an employee by gender: 2016 (marginal effects)

Table 5.27 Impact of disability on a person's probability of self-employment: 2016 (marginal effects)

Table 5.28 Impact of disability on a person's probability of self-employment by gender: 2016 (marginal effects)

Table 5.29 Impact of disability type on a person's probability of self-employment: 2016 (marginal effects)

Table 5.30 Impact of disability type on a person's probability of self-employment by gender: 2016 (marginal effects) ....

Table 6.1 Ratio of representation of people with disabilities by age group: $2018 \ldots \ldots \ldots \ldots \ldots \ldots \ldots . . . . .71$

Table A.1 Demographic profile of people with and without disabilities: 2011 (\%)......................93

Table A.2 Educational attainment by age cohort: 2011 (\%)....................................................94

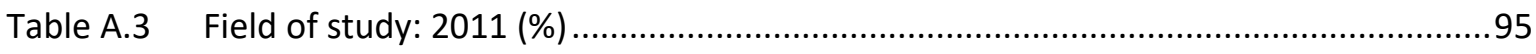

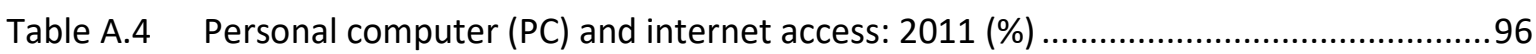

Table A.5 Personal computer (PC) and internet access by disability type: 2011 (\%)...................96

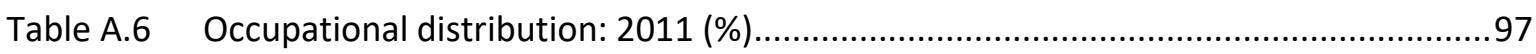

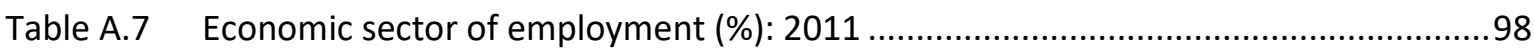

Table A.8 Impact of disability on a person's probability of being an employee: 2011

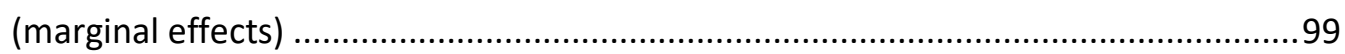

Table A.9 Impact of disability on a person's probability of being an employee by gender: 2011 (marginal effects)

Table A.10 Impact of disability type on a person's probability of being an employee: 2011 (marginal effects)

Table A.11 Impact of disability type on a person's probability of being an employee by gender: 2011 (marginal effects)

Table A.12 Impact of disability on a person's probability of being an employee, with individuals with an intellectual disability excluded and controlling for educational attainment: 2016 (marginal effects)

Table A.13 Impact of disability type on a person's probability of being an employee, with individuals with an intellectual disability excluded and controlling for educational attainment: 2016 (marginal effects)

Table A.14 Impact of number of disabilities on a person's probability of employment: 2016 (marginal effects)

Table A.15 Impact of disability on a person's probability of being an employee by age cohort: 2016 (marginal effects).

Table A.16 Impact of age on a person's probability of being in employment by disability status: 2016 (marginal effects).

Table A.17 Impact of disability on a person's probability of self-employment: 2011 (marginal effects)

Table A.18 Impact of disability on a person's probability of self-employment by gender: 2011 (marginal effects) 
Table A.19 Impact of disability type on a person's probability of self-employment: 2011 (marginal effects)

Table A.20 Impact of disability type on a person's probability of self-employment by gender: 2011 (marginal effects)

Table A.21 Impact of disability on a person's probability of self-employment, with individuals with an intellectual disability excluded and controlling for educational attainment: 2016 (marginal effects)

Table A.22 Impact of disability type on a person's probability of self-employment, with individuals with an intellectual disability excluded and controlling for educational attainment: 2016 (marginal effects)

Table A.23 Country abbreviations in EU-SILC

\section{LIST OF FIGURES}

Figure 3.1 Degree of disability and prevalence of disability by gender: 2004-2019 (\%)..............12

Figure 3.2 Age composition of people with and without disabilities: 2004-2019 (\%) ..................12

Figure 3.3 Educational attainment by disability status: 2004-2019 (\%).....................................13

Figure 3.4 Educational attainment for people aged $21-34$ by disability status:

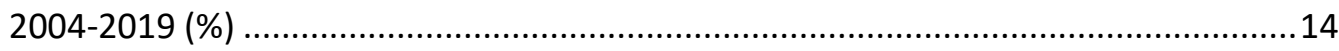

Figure 3.5 Principal economic status by disability status: 2004-2019 (\%) ................................. 15

Figure 3.6 Level of employment by education level and disability status: 2004-2019 (\%) ...........16

Figure 3.7 Full-time work by disability status and severity: 2004-2019 (\%) ................................17

Figure 3.8 Occupation by disability: SILC 2004-2019 (\%) ........................................................ 18

Figure 3.9 Managerial position for working people by disability: SILC 2004-2019 (\%) )................19

Figure 3.10 Mean job satisfaction by gender and disability status: SILC 2013-2018 (\%) ................ 20

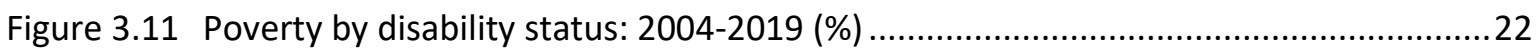

Figure 3.12 Deprivation by work status and disability: 2004-2019 (\%)........................................23

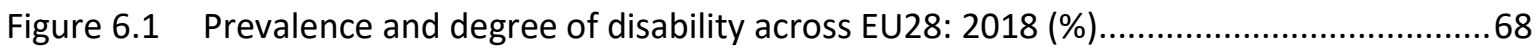

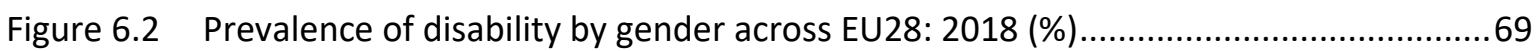

Figure 6.3 Age composition of people with a disability across EU28: 2018 (\%) .......................... 70

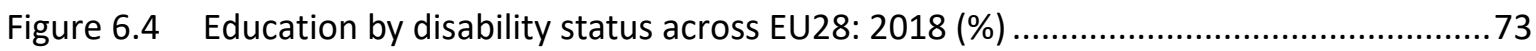

Figure 6.5 Employment rate by disability status across EU28: 2018 (\%) .................................... 74

Figure 6.6 Working status by disability status across EU28: 2018 (\%) ........................................ 75

Figure 6.7 Full-time vs part-time employment by disability status across EU28: 2018 (\%) ...........76

Figure 6.8 Full-time employment by severity of disability across EU28: 2018 (\%) .......................77

Figure 6.9 Managerial position for working people by disability across EU28: 2018 (\%) ..............78

Figure 6.10 Job satisfaction for working people by disability across EU28: 2018 (\%).....................79

Figure 6.11 At risk of poverty by work status and disability across EU28: 2018 (\%) .......................80 



\section{ABBREVIATIONS}

CAPI Computer Assisted Personal Interviewing

CATI Computer Assisted Telephone Interviewing

CSO Central Statistics Office

ESRI Economic and Social Research Institute

EU-SILC European Union Statistics on Income and Living Conditions

FET $\quad$ Further Education and Training

IZA Institute of Labor Economics

NDA National Disability Authority

LFS Labour Force Survey

OECD Organisation for Economic Co-operation and Development

PIAAC Programme for the International Assessment of Adult Competencies

SILC Survey on Income and Living Conditions

TCD Trinity College Dublin 



\section{EXECUTIVE SUMMARY}

\section{RESEARCH CONTEXT}

In 2013, the Irish Government published its National Disability Strategy Implementation Plan 2013-2015. As part of this strategy, a number of goals were set around participation, including job access for people with disabilities. This specific objective recommended a number of actions, including the commitment to publish a comprehensive employment strategy (CES) for people with disabilities. This strategy, the Comprehensive Employment Strategy for People with Disabilities, was published in 2015 for the period 2015-2024. The objective of this strategy, which is cross-governmental, is to support people with disabilities in accessing the labour market.

Building on existing actions in the CES, the National Disability Authority (NDA) commissioned the Economic and Social Research Institute (ESRI) to undertake quantitative research into the workplace skills and abilities of persons with disabilities. To undertake this research, a number of nationally representative data sources were utilised to characterise the skills/educational endowments and gaps among persons with disabilities compared to those without. Specifically, data from the Survey on Income and Living Conditions (SILC), the Programme for the International Assessment of Adult Competencies (PIAAC), the Census of Population, and the European Union Statistics on Income and Living Conditions (EU-SILC) were examined. Where the data permitted, we differentiated those with a disability by type, everyday difficulties (e.g. difficulty dressing), and/or severity level. We also examined the employment characteristics of people with disabilities compared to persons without, and investigated the impact of having a disability on an individual's employment prospects. What follows is a summary of the principal findings from this research, including some discussion on future directions.

\section{MAIN FINDINGS}

In spite of using different datasets, years and measurement of disabilities, a common set of findings emerge from the study. Both SILC and Census data showed that, overall, the proportion of working age people with disabilities has been relatively stable over time. Within SILC, the proportion of the working age population with a disability went from 15 per cent in 2004 to 13 per cent in 2019, with very little difference by gender or by severity level. The Census data also showed the rate of disability to be stable over time, going from 11 per cent in 2011 to 11.5 per cent in 2016.

The EU-SILC data revealed that the prevalence of disability varied extensively across European countries. At 12 per cent, Ireland had the fifth lowest prevalence of disability across the EU28 in 2018, while it was almost 30 per cent in Estonia. While it was outside of the scope of this project to explain the level of prevalence 
of disabilities for each country, one possibility for the variation observed may relate to the fact that in the data used in this study, the measure of disability is a subjective measure and is self-defined. Given this, the variation observed across countries may be due to cultural differences in people's propensity to report health issues. Other hypotheses are outlined in Chapter 6.

Based on the Census data, the main types of disability in Ireland, and which have remained stable between 2011 and 2016, are 'difficulty with pain, breathing or any other chronic illness or condition' (5.4 per cent), 'difficulty with basic physical activities such as walking, climbing stairs, reaching, lifting or carrying' (3.6 per cent), and a 'psychological or emotional condition' (2.9 per cent). Over a third of those people that reported having a disability in 2016 had more than one disability.

\section{Education}

The analysis of the 2012 OECD Programme for the International Assessment of Adult Competencies (PIAAC) survey showed that people with permanent disability and not in employment or education/training had lower scores of literacy and numeracy compared to those without such a disability. They respectively had an average literacy score of 212 and 269 while for numeracy they had an average score of 188 and 258 respectively.

Both SILC and the Census showed that a much smaller percentage of people with disabilities have a third-level qualification compared to working age people without disabilities. While the data indicate that this percentage has increased over time, the education gap between people with and without disabilities remains. Part of the reason for this is due to the older age profile of people with disabilities. Nevertheless, the study revealed that a much smaller percentage of young people with disabilities have a third-level qualification compared to those without.

The over-representation of people with disabilities with lower education levels is a common feature across European countries. However, Ireland is found to be quite distinctive as it has the second highest proportion of working-age people with disabilities with at least a post-secondary education (42 per cent), compared to the EU28 average (25 per cent). This reflects Ireland's higher levels of education overall.

There was substantial variation in educational attainment levels across disability types. Only 6 per cent of people that reported having an intellectual disability in 2016 had a third-level qualification, which was much lower compared to those with a psychological or emotional condition (29.2 per cent), those with deafness or a serious hearing impairment (28.6 per cent), and those with blindness or a serious vision impairment (27.1 per cent). 


\section{Employment}

According to the Census, only a third of the working age people (16-64 years) with disabilities indicated that their main economic status in 2016 was employment. This compares with two-thirds of those without disabilities.

There was considerable variation in the percentages in employment by disability types. In particular, only 14.7 per cent of individuals with an intellectual disability were working in 2016. The same was true of those with 'difficulty with basic physical activities such as walking, climbing stairs, reaching, lifting or carrying' (18.1 per cent) and those that have 'difficulty in learning, remembering or concentrating' (20.7 per cent). On the other hand, a larger proportion of those that reported having 'deafness or a serious hearing impairment' (45.7 per cent) or 'blindness or a serious vision impairment' (34 per cent) were in employment.

Analysis of the Census also showed that having a disability was found to have a negative impact on an individual's likelihood of being in employment and that the negative effect was stronger for men than for women. The Census analysis showed also that the negative effect was greater for employees than for the self-employed. Again, the impact varies by disability type and people with a 'psychological or emotional condition' or 'difficulty with basic physical activities such as walking, climbing stairs, reaching, lifting or carrying' are most severely impacted.

The analysis of the SILC data revealed that while the proportion of people in employment fell during the Great Recession regardless of disability status, by 2019 people with disabilities had still not benefitted from the economic recovery to the same extent as those without as they were not back at their pre-recession employment levels.

An EU comparison shows that Ireland does not perform well in relation to the working status of people with disabilities, as it has the fourth lowest employment rates for people with disabilities (36 per cent). Among working age people with disabilities it has also a much lower proportion of people working full-time (66 per cent vs 74 per cent for the EU28). It also has one of the largest employment gaps between people with and without disabilities. Moreover, unlike most European countries, the severity of disability in Ireland is not strongly associated with working status. This suggests that in Ireland the barriers to work could be related to other factors other than the severity of disability.

The analysis of the Census data showed that people with an intellectual disability are less likely to be managers, directors or senior officials; or in professional occupations or associate professional and technical occupations. On the other hand, people with deafness or a serious hearing impairment or with blindness or a serious vision impairment were found to be more likely to be in these positions. 
The SILC examination revealed that people with disabilities are much more likely to experience poverty and social exclusion than people without disabilities. This is also true in all European countries. While being employed helps to considerably reduce the risk of poverty for all people, working people with disabilities are still experiencing higher poverty risks than working people without disabilities. Again, this is true in all European countries.

Ireland has one of the lowest at risk of poverty rates for employed people without disabilities, but, on average, it is much higher for people with disabilities. The poverty gap is even greater in Ireland, and is one of the largest across EU countries, when we compare people without disabilities and people with disabilities that are unemployed or inactive.

\section{FURTHER RESEARCH}

The analyses conducted in this study highlighted the gaps in education and labour market outcomes between people with and without disabilities, and also poverty outcomes. To deepen our understanding of the consequences of these differences it would be important to explore and compare the earnings of employed people with and without disabilities, as well as all other sources of income. This would provide a good insight about whether there is earnings inequality between people with and without disabilities that share the same characteristics. In addition, this can provide valuable information about the role that social protection can play to support the income of working people with disabilities that are exposed to much greater risk of poverty than working people without disabilities.

What is also needed to gain a better understanding of the experiences of those with disabilities in the labour market, including those trying to gain entry, is qualitative research. Specifically, such research should engage with key stakeholders, including persons with lived experience of disability. Such research was outside of the scope of the current study, but supplementation of the quantitative research conducted in this report with qualitative analysis has the potential to provide additional, and deeper, insights for policymakers that could assist in the development of supports needed by people with disabilities to progress towards employment. Such work could also involve case studies with employers to better understand what might be needed for them to grow their employment of people with disabilities. This type of examination was recently undertaken by the OECD in a study on the employment of persons with disabilities in Ireland. ${ }^{2}$

The advancements that have taken place within the education system to support people with disabilities over the last decade are noted. Nevertheless, the analysis 
undertaken in this report still highlights that a much smaller proportion of young people with disabilities have third-level qualifications compared to their counterparts with no disabilities. Previous research has identified the lack of transition support from second-level to further education and training or employment identified as a big issue (Scanlon et al., 2020). This is coupled with the lack of career guidance for many students with disabilities prior to leaving school. Work around improving transition supports is ongoing through the CES, but there is room for further qualitative research to explore some barriers more fully.

Again, while it is noted that considerable progress has been made within the education system over the last decade to support those with disabilities, the opportunities need to be there for these individuals when they go to transition into the labour market. Otherwise, the full return on such investments that have been made, and continue to be made, by the education sector will not be achieved, and this, ultimately, will be a cost borne by individuals with disabilities. 



\section{CHAPTER 1}

\section{Introduction}

\section{$1.1 \quad$ INTRODUCTION}

In 2013, the Irish Government published its National Disability Strategy Implementation Plan 2013-2015, which aimed to promote the social inclusion of people with disabilities. The strategy also set out a wide range of other goals around participation, including job access for people with disabilities. This specific objective recommended a number of actions, including the commitment to publish a Comprehensive Employment Strategy (CES) for people with disabilities. This strategy was published in 2015 for the period 2015-2024. The objective of this strategy, which is cross-governmental, is to support people with disabilities in accessing the labour market.

Building on existing actions in the CES, the NDA seeks insight into the workplace skills and abilities of persons with disabilities, including how this varies by disability type. In this report, we use a number of nationally representative data sources to characterise the skills/educational endowments and gaps among persons with disabilities compared to those without disabilities. Where the data permits, we differentiate those with a disability by type, everyday difficulties and/or severity level. We also examine the employment characteristics of people with disabilities compared to persons without a disability. In addition, we examine the impact of having a disability on an individual's likelihood of being in employment, along with how this varies by disability type.

\subsection{EDUCATIONAL CHANGE}

It is important to note key changes in the Irish school and broader educational system, which provide context for our analysis and results. The same is true with regards to the labour market, and changes that have taken place here over the last decade or so. For example, the effect of the Great Recession on employment and the labour market recovery since this time period, the move away from sheltered workshops to more mainstream employment for people with disabilities, etc. Much of this has been covered in detail in the Government's 2015-2024 CES. Therefore, in this section we focus on outlining educational changes that have taken place.

Since the early 1990s, there have been significant changes to Irish policy and legislation around special education. At this point, Irish policy began to be influenced by international policy developments, where human rights-based (instead of needs-based) principles were being endorsed. In particular, the Convention on the Rights of the Child created obligations for governments that 
ratified it in relation to the rights of all children, including those with disabilities (Stevens and O'Moore, 2009; McCoy et al., 2016). As recently as the 1990s, legal actions by parents seeking educational rights for children with severe disabilities prompted appropriate provision for these students and a shift towards inclusive schools. The Education for Persons with Special Educational Needs (EPSEN) Act set out important changes - although not all implemented - followed by a series of changes in resource allocation, culminating in the removal of the requirement for students to be diagnosed in order to access supports in schools (Kenny et al., 2020).

Internationally, it is increasingly argued that the identification of special educational needs and disabilities is not a straightforward process and that there are tensions and complexities that must be recognised (Griffin and Shevlin, 2008; McCoy et al., 2016). Analysis of Growing Up in Ireland cohort data provides a special education prevalence rate of 25 per cent at mid-primary school level, with this evidence highlighting the difficulties in using government administrative data sources in cross-national comparative statistics (McCoy et al., 2016). In particular, international evidence points to variation in prevalence depending on the resource allocation systems in place, with resource allocation based on learners' profile and SEN diagnosis being linked to the over-identification of SEN students in schools (Kenny et al., 2020). Resource allocation systems to support students with disabilities differ too in further and higher education systems within and across countries, making cross-national comparison of prevalence and outcomes difficult.

Policy at further and higher education has placed an emphasis on widening access for under-represented groups, including people with a disability. The Fund for Students with Disabilities (FSD) provides funding to higher education and further education institutions to enable service and support provision for students with disabilities. The funding is allocated based on the number of students with a disability in the preceding year. The fund is currently managed by the Higher Education Authority (HEA) for the higher education sector (HEA, 2017), and by SOLAS for the further education sector. Data collected as part of the FSD illustrates an increase in the prevalence of disability among higher education students. In 2015, 7.8 per cent of new higher education entrants had a disability, increasing to 12.3 per cent in 2019 (McCoy et al., forthcoming). The scale of change over time is notable. Students with a disability accounted for 1.1 per cent of the total undergraduate population in the academic year 1998/1999 (McCoy et al., 2010). The HEA reports the percentage of students with a disability among all new entrants to higher education reached 10 per cent in 2016/2017 (HEA, 2021). In terms of the further education and training sector, it is more difficult to assess change over time in the proportion of learners with a disability. In 2019, 7.3 per cent of all learners enrolled in FET had at least one type of disability (SOLAS, 2020). 


\subsection{STRUCTURE OF REPORT}

The remainder of this report is structured as follows. Chapter 2 sets out the data and methodologies utilised in this study. Each of the following four chapters looks at the education and employment issues outlined above using various nationally representative datasets: the Survey on Income and Living Conditions (SILC) is examined in Chapter 3, the Programme for the International Assessment of Adult Competencies (PIAAC) data in Chapter 4, the Census data in Chapter 5, and the European Union Statistics on Income and Living Conditions (EU-SILC) in Chapter 6. Finally, the main conclusions identified in the study are summarised in Chapter 7. 



\section{CHAPTER 2}

\section{Data and Methodology}

\section{$2.1 \quad$ DATA}

\subsubsection{Overview}

The various data sources that we drew upon in compiling this report are as follows:

- $\quad$ Census: 2011 and 2016;

- $\quad$ OECD Programme for the International Assessment of Adult Competencies (PIAAC) Survey: 2012;

- Survey on Income and Living Conditions (SILC): 2004, 2011 and 2019; and

- $\quad$ European Union Statistics on Income and Living Conditions (EU-SILC): 2018. In reading this report, one needs to be bear in mind that the results derived from these data sources are not directly comparable. This is due to, for example, the utilisation of different data collection techniques (face-to-face, phone, etc.), variation in the data collection time points, differences in the nature of the data (survey data, census data), and differences in the disability question asked in the questionnaires that underlie each data source.

\subsubsection{Labour Force Survey data}

We also intended to examine Labour Force Survey (LFS) data from 2011 and 2016, and we expected to see similar disability findings to those in the Census because of the same disability questions being asked in both questionnaires at the same time points (2011 and 2016). However, the results in Table 2.1 show that there is considerable variation in the prevalence of disability reported between the two data sources. The SILC figure for 2011, which is based on a different disability question to that asked in the Census and LFS, is closer to the Census result than the LFS figure is. ${ }^{3}$ The same discrepancy in results between the Census and LFS is evident for disability by type (Table 2.2) and everyday difficulties (Table 2.3). There are several potential reasons for these discrepancies. One is the data collection mode used: the LFS is a large-scale, nationwide survey of private households in Ireland, while the Census is a complete enumeration of every person living in Ireland. The LFS data are captured using a combination of face-to-face and telephone data collection techniques, while the Census is a self-completion questionnaire. Given that the sampling frame for the LFS is all private households, individuals living in institutions, including disability residential services, are not 
included. Another contributing factor is likely to be the high percentage of proxy responses in the LFS: the proportion of proxy answers for the population aged 15 and over in the LFS in Quarter 2, 2011 and Quarter 2, 2016 was 47 per cent and 49 per cent, respectively. A Eurostat comparative study on disability and employment based on the EU-LFS (Eurostat, 2015), which all national LFSs contribute to, found that proxy answers on behalf of other household members tended to underestimate health issues (longstanding problem or basic activity difficulty).

TABLE 2.1 PREVALENCE OF DISABILITY AMONG WORKING AGE POPULATION (15-64 YEARS OF AGE) (\%)

\begin{tabular}{|l|r|c|}
\hline & 2011 & 2016 \\
\hline Census & 11.0 & 11.5 \\
\hline LFS & 7.1 & 7.4 \\
\hline SILC & 12.9 & - \\
\hline
\end{tabular}

Source: $\quad$ Results derived by authors using Census, LFS (Q2) and SILC microdata.

TABLE 2.2 PREVALENCE OF DISABILITY AMONG WORKING AGE POPULATION (15-64 YEARS OF AGE): TYPE (\%)

\begin{tabular}{|c|c|c|c|c|}
\hline & 2011 & 2011 & 2016 & 2016 \\
\hline Type & LFS & Census & LFS & Census \\
\hline Blindness or a serious vision impairment & 2.8 & 0.8 & 2.3 & 0.8 \\
\hline Deafness or a serious hearing impairment & 4.7 & 1.2 & 3.7 & 1.2 \\
\hline $\begin{array}{l}\text { Difficulty with basic physical activities such as walking, } \\
\text { climbing stairs, reaching, lifting or carrying }\end{array}$ & 30.0 & 3.5 & 29.3 & 3.6 \\
\hline Intellectual disability & 7.6 & 1.2 & 8.3 & 1.3 \\
\hline Difficulty in learning, remembering or concentrating & 6.5 & 2.3 & 8.4 & 2.5 \\
\hline Psychological or emotional condition & 14.2 & 2.3 & 15.3 & 2.9 \\
\hline $\begin{array}{l}\text { Difficulty with pain, breathing or any other chronic illness } \\
\text { or condition }\end{array}$ & 59.3 & 5.1 & 59.9 & 5.4 \\
\hline
\end{tabular}

TABLE 2.3 PREVALENCE OF EVERYDAY DIFFICULTIES AMONG THOSE WITH DISABILITIES OF WORKING AGE (15-64 YEARS OF AGE): 2011 AND 2016 (\%)

\begin{tabular}{|l|c|c|c|c|}
\hline & \multicolumn{2}{|c|}{2011} & \multicolumn{2}{|c|}{2016} \\
\hline Everyday Difficulties: & LFS & Census & LFS & Census \\
\hline Difficulty dressing & 8.2 & 12.6 & 8.9 & 13.3 \\
\hline Difficulty going outside & 15.8 & 17.3 & 17.0 & 18.7 \\
\hline Difficulty work/study & 48.9 & 35.6 & 52.0 & 36.0 \\
\hline Difficulty other activities & 36.1 & 29.5 & 37.9 & 30.6 \\
\hline
\end{tabular}

Source: $\quad$ Results derived by authors using Census and LFS (Q2).

Given the discrepancy found between the LFS and Census disability rates, and for the reasons for the variation in the findings identified here, we do not present any examinations from the LFS but focus instead on the other four outlined data 
sources: SILC, PIAAC, Census and EU-SILC. Additional information on each of these data sources is presented next.

\subsubsection{Data sources overview}

\subsubsection{Survey on Income and Living Conditions (SILC)}

The SILC is a voluntary survey of private households. Since June 2003, the survey has been conducted every year by the CSO. ${ }^{4}$ The main aim of SILC is to collect information about the income and living conditions of households for the purpose of monitoring poverty and social exclusion. The SILC collects individual and household information across a wide range of topics, such as household and individual income, living conditions, housing conditions, labour market status, education, health, etc. In 2004 the total completed sample size was 5,477 households and 14,272 individuals. In 2011, it was 4,333 households and 11,005 individuals, and in 2019 it was 4,183 households and 10,698 individuals.

The measure of disability in the SILC data is based on the answer to a single question asked to all household members aged 16 and over. The question is: 'For at least the last 6 months have you been limited in activities people usually do, because of a health problem?'. There are three possible answers; 'Yes, strongly limited', 'Yes, limited', 'Not limited'. People answering that they are strongly limited or limited are considered as having a disability. The measure of disability is therefore a subjective self-evaluation for having or not having limitations in daily activities as well as the extent to which people experience such limitations.

\subsubsection{Programme for the International Assessment of Adult Competencies Survey (PIAAC)}

The OECD Programme for the International Assessment of Adult Competencies (PIAAC) is an international survey of adults' skills and competencies. The survey was carried out in Ireland between August 2011 and March 2012.5 It was administered by the Central Statistics Office (CSO) on behalf of the Department of Education and Skills (DES). In total, 5,983 adults aged 16-65 completed the survey, which was a 72 per cent response rate. All respondents were interviewed in their home.

The survey assessed literacy and numeracy skills, along with the ability to solve problems in technology-rich environments. The PIAAC also collected information on how adults' skills were used at work, at home and in the community. In addition, the survey collected a rich array of background information on its participants, 
such as their gender, age, nationality, disability status, educational attainment (including that of their mother and father), employment situation, etc.

During the PIAAC survey interview, respondents were asked if among a list of statements (full-time employed, part-time employed, unemployed, student etc.) which one best described their current situation and, if more than one statement applied to them, which one best described the way they see themselves. People answering 'Permanently disabled' are therefore identified as people with disabilities. This is a very restrictive definition of disability as not only does it exclude those with a disability that are employed or in education/training etc but also the labelling 'permanently' might identify mostly people with severe health conditions.

\subsubsection{Census data}

The Census of Population is conducted every five years in Ireland, covering all persons and households, which is approximately 4.76 million persons and 1.76 million households. ${ }^{6}$ The Census is a self-completed questionnaire, and usually takes place in April. The type of individual-level information captured includes age, gender, household composition, marital status, place of birth, nationality, ethnicity, religion, Irish language, disability, health, education, economic status, occupation, industry and place of work. In relation to the household data, this includes accommodation type, year accommodation constructed, nature of occupancy, rent paid, number of rooms, heating/water/ sewerage facilities, cars, and personal computer and internet access. There are 4,588,252 individuals in the 2011 Census microdata file, and 4,761,865 in the 2016 Census dataset.

In the Census, a respondent is defined as having a disability if he/she replied 'yes' to any of the categories in the following two questions:

1. Do you have any of the following long-lasting conditions or difficulties [Yes/No]?

(i) Blindness or serious visual impairment, (ii) Deafness or a serious hearing impairment, (iii) Difficulty with basic physical activities such as walking, climbing stairs, reaching, lifting or carrying, (iv) An intellectual disability, (v) Difficulty with learning, remembering or concentrating, (vi) A psychological or emotional condition, (vii) Difficulty with pain, breathing, or any other chronic illness or condition. 
2. If yes to any of the categories specified in Question 1, do you have any difficulty in doing any of the following:

(i) Dressing, bathing or getting around inside the home, (ii) Going outside the home alone to shop or visit a doctor's surgery, (iii) Working at a job or business or attending school or college, (iv) Participating in other activities, for example leisure or using transport.

These are also the two questions used in the Census to identify disability type (1) and everyday difficulties (2).

\subsubsection{European Union Statistics on Income and Living Conditions (EU-SILC)}

SILC (see above) is the Irish component of the broad EU-SILC survey. The purpose of the EU-SILC is to provide comparable cross-sectional and longitudinal microdata to monitor income, poverty, social exclusion and living conditions across Europe. The topics covered in the EU-SILC are identical to the ones in the SILC, as the survey collects the following information on households and individuals: income, poverty, social exclusion, housing, labour market, education and health. The EU-SILC was launched in 2003 with only six Member States (Belgium, Denmark, Greece, Ireland, Luxembourg and Austria) and Norway. These countries were then joined over time by other EU Member States and non-EU Member States (Iceland and Switzerland for example). For this analysis, we use the 2018 data, which include 28 Member States. The number of households in 2018 varies from 3,823 in Malta to 24,305 in Greece (4,382 in Ireland), and the number of individuals from 9,815 in Malta to 56,660 in Greece (11,131 in Ireland). The measure of disability in the EU-SILC is identical to the one in the Irish SILC data (see above).

\subsubsection{Benefits of each data source}

While the demographic, education and labour market information collected in the SILC and Census are somewhat similar, the SILC data allowed us to descriptively examine the impact of disability severity levels, along with poverty and deprivation levels among individuals with and without disabilities. The main reason for using the Census data is that the data enabled us to distinguish between disability type in our analyses, along with examining everyday difficulties. In addition, the large number of respondents, and therefore observations in the microdata, permitted us to econometrically investigate the impact of having a disability on a person's likelihood of being in employment, and to identify how this varied by professional status (employee or self-employment), disability type and gender. The main benefit of the PIAAC data is that the data allowed us to identify the literacy and numeracy levels of individuals with and without disabilities. However, we could not conduct an econometric analysis of employment with these data because the sample size was too small. Finally, the EU-SILC data allowed us to identify and compare the situation in Ireland for people with disabilities with the situation for such individuals in other EU countries. 


\subsection{METHODOLOGY}

Both descriptive and econometric techniques are utilised in this report. Where possible, we analysed more than one time point for each data source used in the study. This was undertaken in order to identify if changes were taking place over time in the various education and labour market characteristics examined. However, it was not feasible to do this with the PIAAC data, as 2012 is the most recent time point for which such data exist. We also only focused on the most recent EU-SILC data available to us, which was 2018, for our cross-county comparative analysis work. For the other two data sources - the SILC and Census, we selected 2011 as the earlier time point for our analyses and then selected the most recent time point for which data were available: 2016 for the Census and 2019 for the SILC. With the SILC data, we also examined 2004 in order to provide a longer-term horizon for the analyses conducted with those data.

Using the Census data, econometric techniques were employed to isolate the individual impact of having a disability on someone's employment likelihood while simultaneously controlling for a range of other factors that can impact this outcome. For example, factors such as an individual's age, educational attainment, gender, geographic location, etc. In examining the impact that having a disability has on a person's likelihood of being in employment, we are modelling the choice between two discrete alternatives - being in employment or not. Probit models are used to estimate such binary outcomes.

In this analysis, we focus on the working population aged 15 to 64. Initially, we examine the impact of having a disability on someone's likelihood of being an employee compared to those with no disability (i.e. the reference group), ${ }^{7}$ and then we run separate models to identify its impact on self-employment. In addition to examining the overall impact of having a disability on a person's probability of being in employment, we also investigate how its impact varies by type of disability. Finally, we estimate separate male and female models in order to identify if the impact of having a disability varies by gender.

The reference group, also known as the reference category, is the group against which the estimated result(s) for the group (groups) of interest is (are) being compared. For example, those with a disability (group of interest) are compared against those with no disability (reference group) in the employment analyses. For the age control that is included in our employment models, those aged 15-19, 20-24, 25-34, 45-54 and 55-64 are compared with those aged 35-44 (reference group). Each control variable in our estimated models (e.g. gender, ethnicity) has a reference category: the reference category is specified in each results table. 


\section{CHAPTER 3}

\section{Survey on Income and Living Conditions (SILC): 2004, 2011 and 2019}

\section{$3.1 \quad$ INTRODUCTION}

In this chapter we explore the relationship between disability and employment using the Irish SILC data for the years 2004, 2011 and 2019. We use the first and last available years of SILC data (2004 and 2019) as well as 2011 as a comparison with the Census of Population data. We therefore cover a period of pre-recession (2004), recession (2011) and recovery (2019). The SILC is the primary data source to measure and monitor poverty and social exclusion in Ireland (Government of Ireland, 2007; DEASP, 2019; 2020).

The measure of disability in the SILC data was described in Chapter 2: it is a subjective self-evaluation for having limitations in daily activities, in addition to the extent to which people experience such limitations.

The structure of this chapter is organised as follows. First, we compare people aged 16-64 with and without disabilities across a range of demographic characteristics, such as age, gender and education. We then explore the differences in labour market characteristics of both populations, including labour market outcomes by disability severity level. Finally, we look at poverty exposure for people with disabilities, and the crucial role of employment status as a protective factor against poverty. In this chapter, we present descriptive results only, while in the Census of Population chapter we present, in addition to descriptives, econometric results.

\subsection{SOCIO-DEMOGRAPHIC CHARACTERISTICS}

An analysis of the SILC data shows that there has been very little change in the prevalence of disability among the working age population between 2004 and 2019, as it went from 15 per cent to 13 per cent, with no change between 2011 and 2019. Almost a third of people with disabilities have very strong limitations in their activities, and this has changed very little between 2004 and 2019.

As can be seen from Figure 3.1, there was a slightly higher proportion of females with disabilities in 2004: 15.9 per cent for females compared to 14.5 per cent for males. This result was due to slightly more females experiencing greater limitations. However, the gender difference in overall level of disability and severity level disappeared over time. 
FIGURE 3.1 DEGREE OF DISABILITY AND PREVALENCE OF DISABILITY BY GENDER: 2004$2019(\%)$

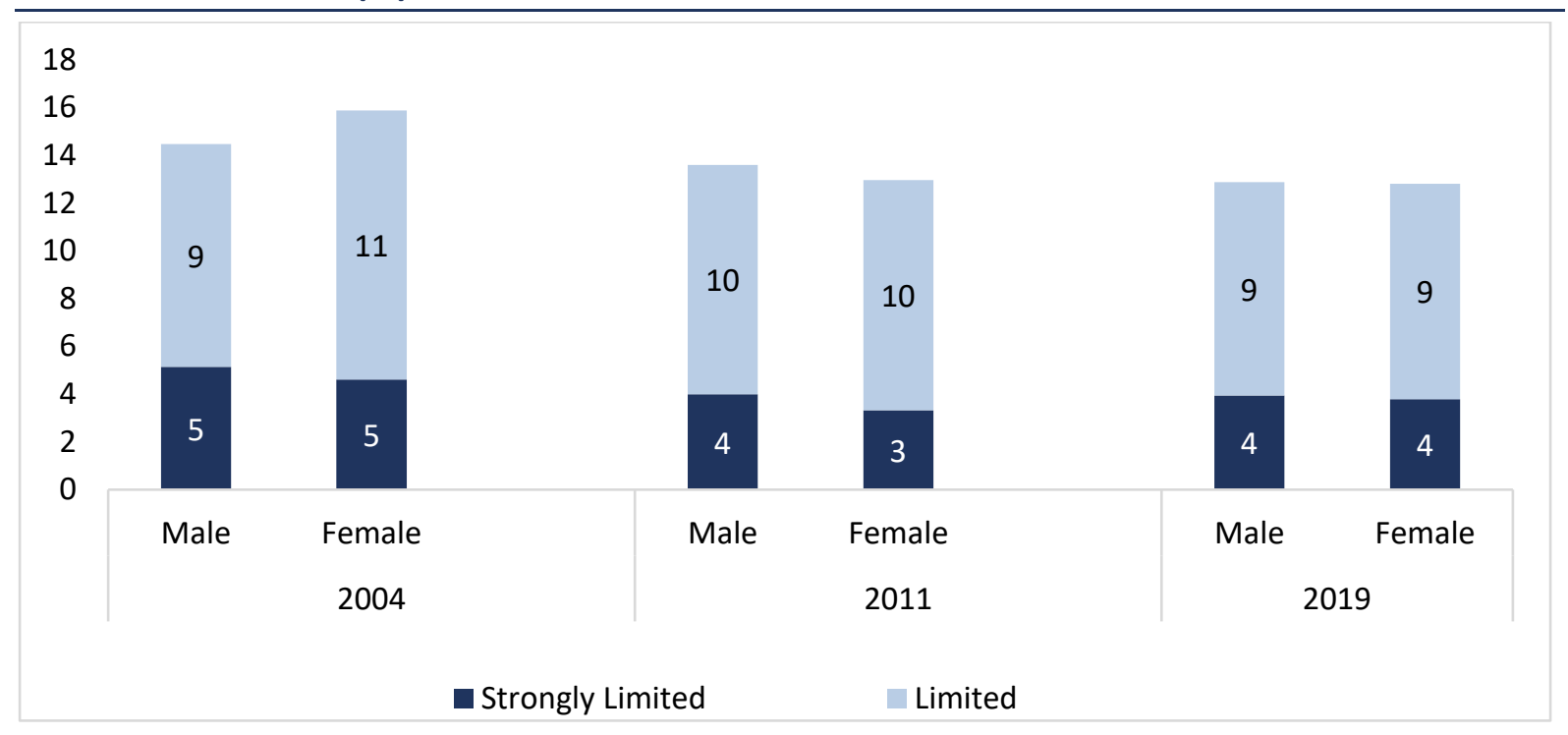

Sources: SILC 2004-2011-2019.

Note: Working age population (16-64 years of age).

In Figure 3.2 we present the age distribution of people by disability status. The main differences in the age composition between people without and with disabilities appear at both ends of the age distribution. There are proportionally twice as many people aged 16 to 34 among people without disabilities than there are among people with disabilities. The situation is reversed though for the older age group. Specifically, there are over twice as many people aged 55 to 64 among people with disabilities than there are among those without.

FIGURE 3.2 AGE COMPOSITION OF PEOPLE WITH AND WITHOUT DISABILITIES: 2004-2019 (\%)

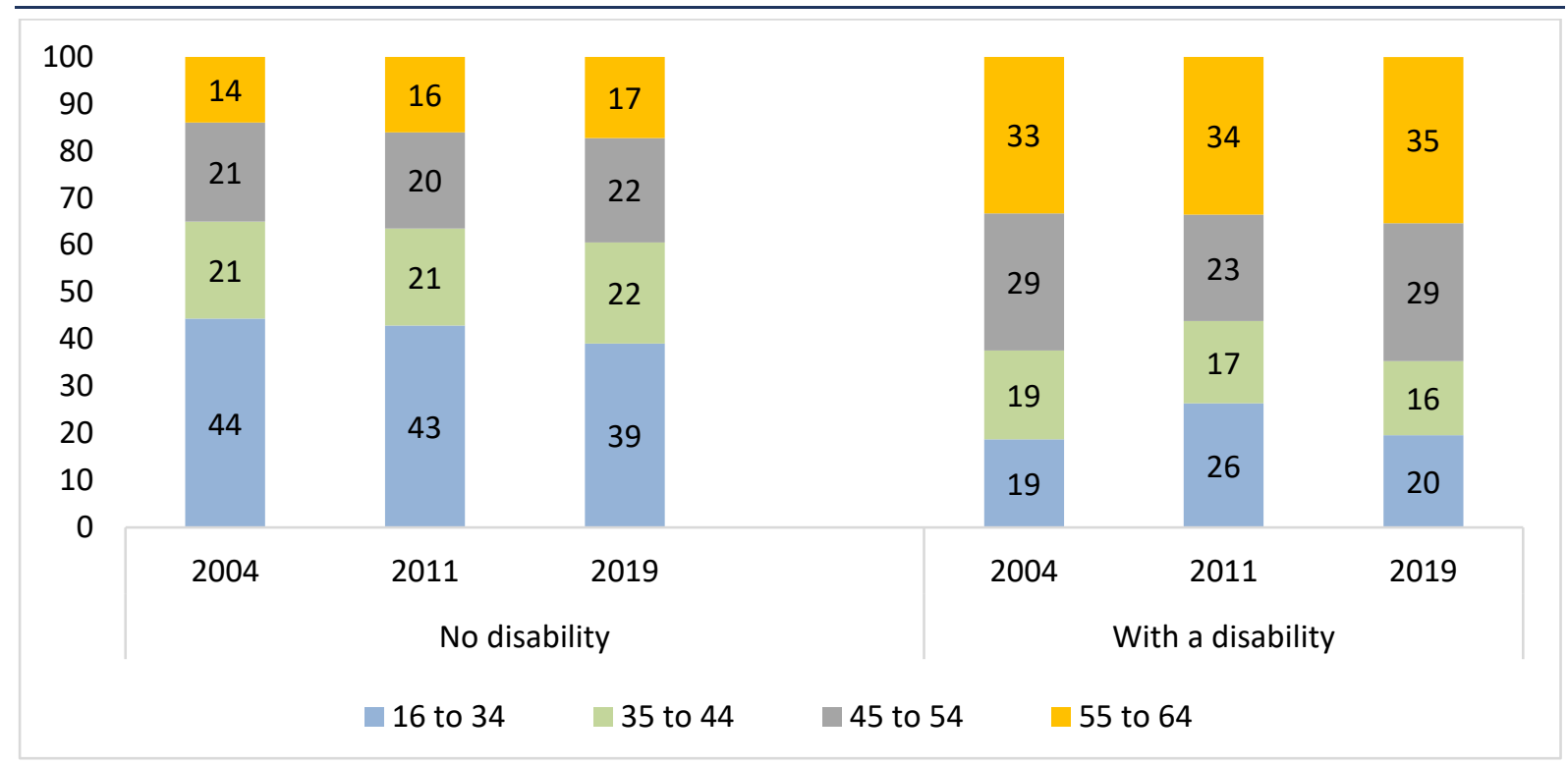

Sources: SILC 2004-2011-2019.

Note: Working age population (16-64 years of age). 
The 2016 Census shows that higher educational attainment decreases with age for the total population (CSO, 2017). As we can see in Figure 3.3, and will also be seen in Chapter 5, this is impacting on the distribution of educational attainment of those with disabilities because of its older age structure.

Regardless of disability, between 2004 and 2019 there has been a reduction in the proportion of people with primary or lower education and an increase in the proportion with post-secondary and above qualifications. However, the rise in the latter has been much greater among those without disabilities than those with. Most people with disabilities have secondary levels of education, and this has not changed very much over time. This was also the case for people without disabilities until 2011, but by 2019 the majority of these individuals had a post-secondary or higher level of education: it reached 57 per cent in 2019 compared to 39 per cent among those with disabilities. Since 2004, the education gap between people with and without disabilities for at least a post-secondary education has increased: in 2004 there is a 13 percentage point difference, but by 2019 the difference had increased to 18 percentage points.

\section{FIGURE 3.3 EDUCATIONAL ATTAINMENT BY DISABILITY STATUS: 2004-2019 (\%)}

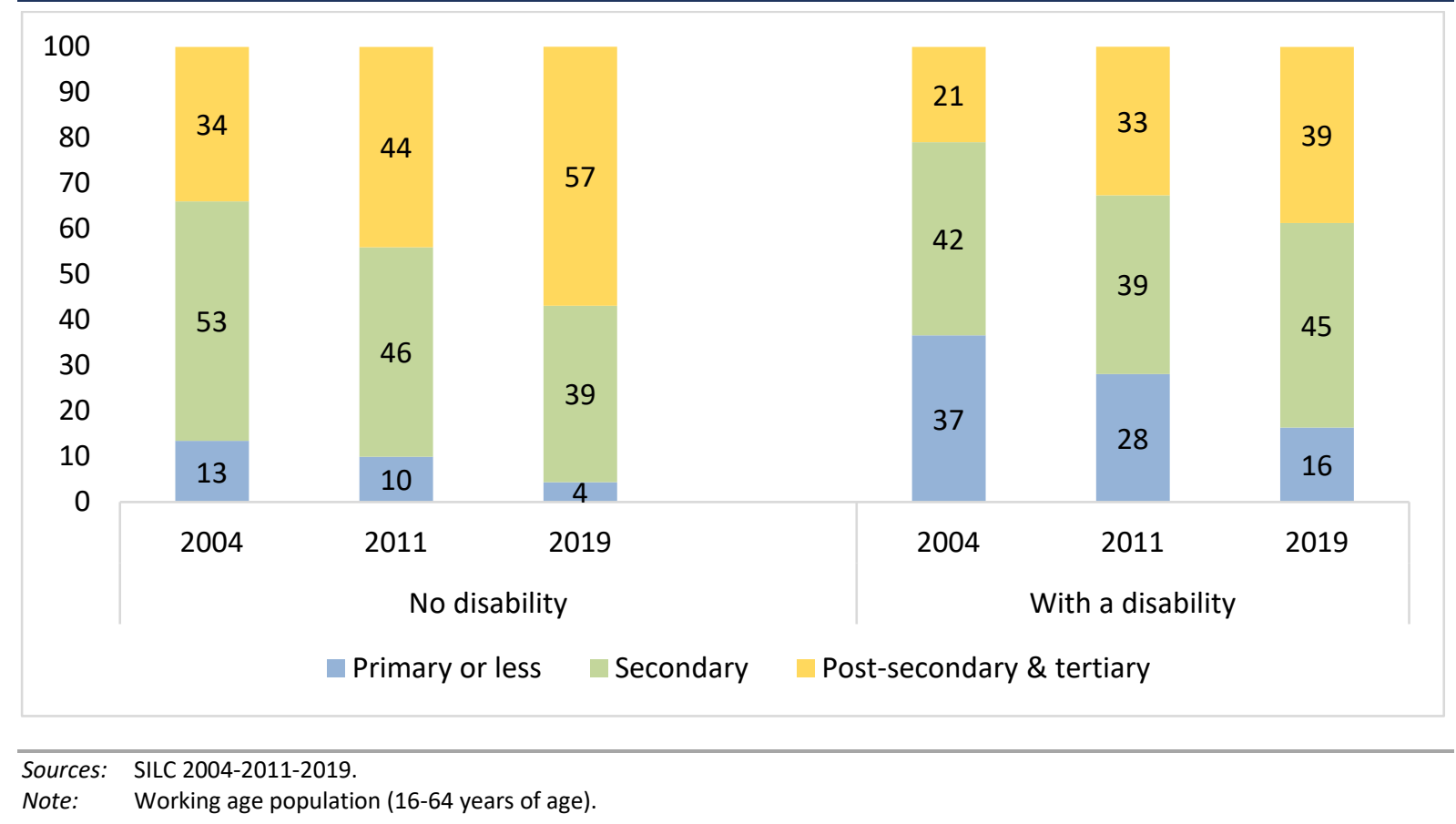

While the results from Figure 3.3 are interesting, it is difficult to compare the education levels of individuals with and without disabilities because of their very different age profiles (Figure 3.2). Therefore, in order to compare more like with like, we report in Figure 3.4 the education level attained by a young age group 
(aged 21 to 34), which is the age group most likely to have completed postsecondary or tertiary education. ${ }^{8}$

As was seen in Figure 3.3, there has been a large increase in the proportion of people aged 21 to 34 with at least post-secondary education level, regardless of disability status (Figure 3.4). However, while for young people aged 21 to 34 without disabilities the proportion increased from half of this group in 2004 to two-thirds in 2019, it went from over a third in 2004 to half of people with disabilities in 2019. As a result, the education gap for at least post-secondary education between young people without and with disabilities remained the same in 2019 as it was in 2004.

\section{FIGURE 3.4 EDUCATIONAL ATTAINMENT FOR PEOPLE AGED 21-34 BY DISABILITY STATUS: 2004-2019 (\%)}

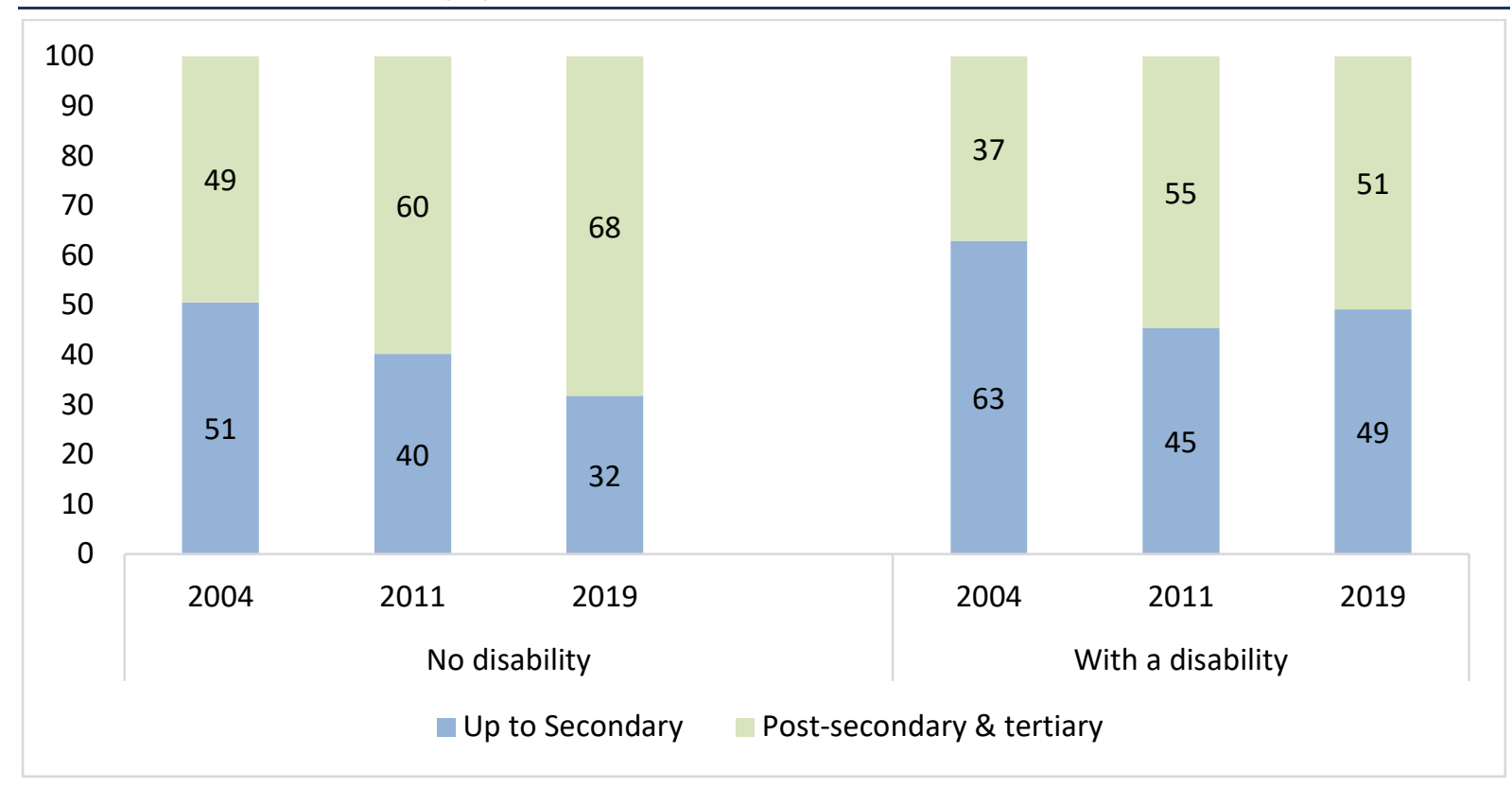

Sources: SILC 2004-2011-2019.

Note: $\quad$ Working age population (16-64 years of age).

\subsection{EMPLOYMENT CHARACTERISTICS}

During the SILC interviews, respondents are asked to describe their principal economic status (PES) with regard to employment, unemployment, etc. ${ }^{9}$

On average, two-thirds of people without disabilities define themselves as being at work, while it is less than a third for people with disabilities (Figure 3.5). Both groups experienced the negative consequences of the Great Recession in 2011 with falling proportions at work (and corresponding increases in unemployment)

$8 \quad$ We grouped together 'primary or lower' and 'secondary' educational attainment levels in order to have enough cases to comply with CSO statistical disclosure rules.

9 The PES is a subjective self-determination measure of a person's economic status (employed, unemployed, retired, student, etc.). It differs from the International Labour Organization's (ILO's) measure of employment: for further information on the ILO's employment measure, see: Microsoft Word - BLS Article 2007-1 Ralf English.doc (ilo.org). 
before the numbers rose again in 2019 (and unemployment fell). However, while the proportion of people without disabilities working in 2019 surpassed its 2004 level (70 per cent compared to 65 per cent), the percentage at work for those with disabilities had not returned to its pre-Recession level of 33 per cent in 2004. Thus, the employment recovery for people with disabilities was much slower than for those without after the Great Recession.

The proportion of people on home duties fell over time regardless of disability status. ${ }^{10}$ On average, there are one-and-a-half times more people with disabilities on home duties than is the case for those without. While the proportion of people with disabilities on home duties fell by half between 2004 and 2019, there was a corresponding increase in the proportion indicating their PES to be illness/ disability: this latter percentage went from 27 per cent in 2004 to 37 per cent in 2019. This result, however, could be due to a change in people's perception with regard to their PES where individuals with disabilities no longer describe themselves as being on home duties but being ill or disabled.

FIGURE 3.5 PRINCIPAL ECONOMIC STATUS BY DISABILITY STATUS: 2004-2019 (\%)

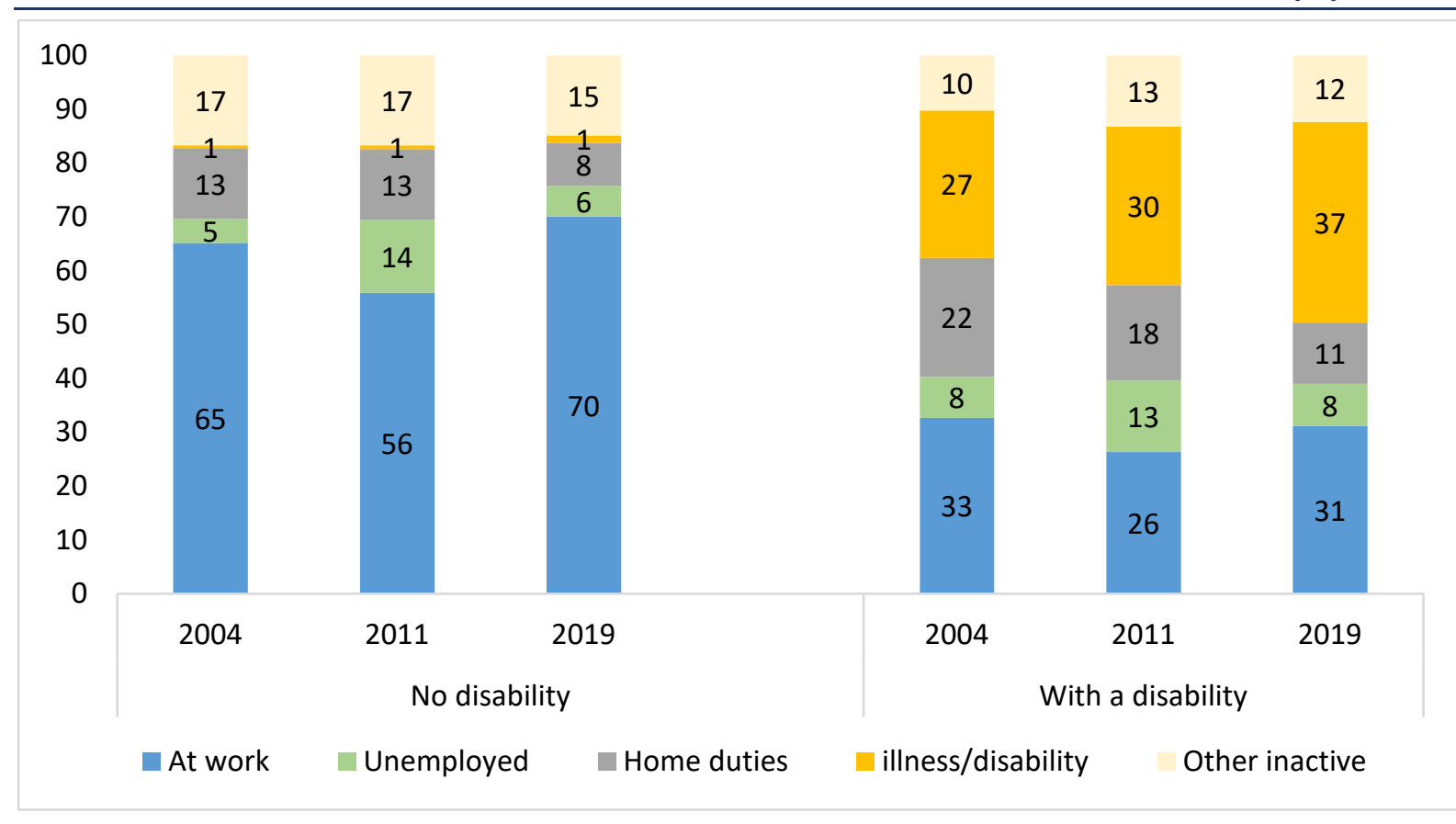

Sources: SILC 2004-2011-2019.

Note: Working age population (16-64 years of age).

In Figure 3.6 we compare the proportion of people that are working by education level, in order to see if the working gap seen in Figure 3.5 between those without and with disabilities decreases as education levels increase. 
As expected, the proportion of people at work is larger among those with higher levels of educational attainment regardless of disability status. Without any exception, all groups experienced the negative labour market impact of the Great Recession, with the numbers at work falling between 2004 and 2011. The distribution of the proportion of people at work across education and disability takes the form of a $\mathrm{U}$ shape over time. While approximately half of people without disabilities with secondary or less levels of education are at work, this is only between one-quarter and one-fifth for people with disabilities. This educational gap narrows but still exists as we move to higher levels of educational attainment. For people without disabilities with at least a post-secondary qualification, on average eight out of ten are at work while it is only one-in-two for people with disabilities. As observed in Figure 3.6, we again note here that across all education levels, by 2019 people without disabilities had recovered to pre-recession levels of employment while this was not the case for people with disabilities.

\section{FIGURE 3.6 LEVEL OF EMPLOYMENT BY EDUCATION LEVEL AND DISABILITY STATUS: 2004-2019 (\%)}

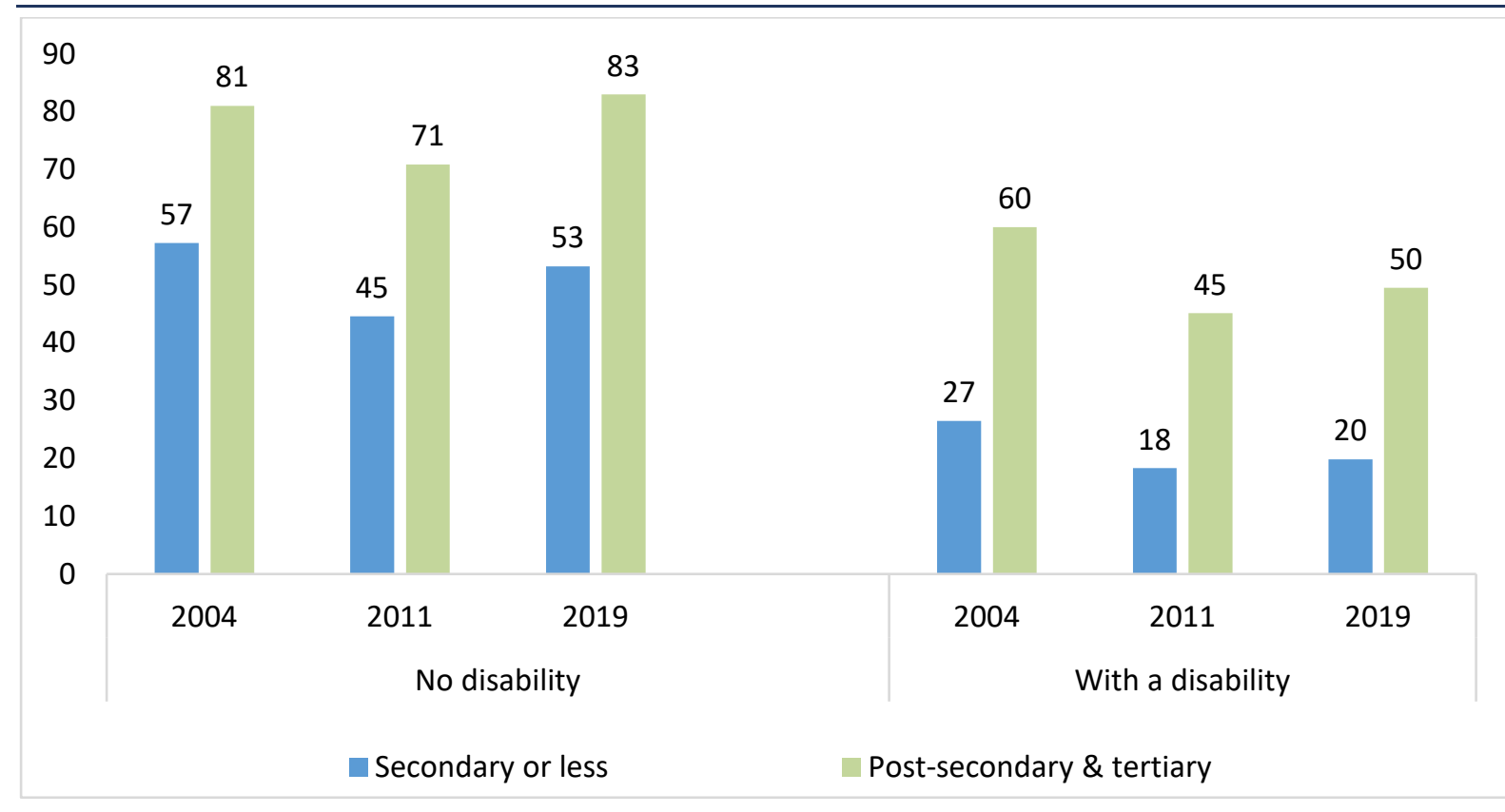

Sources: SILC 2004-2011-2019.

Note: $\quad$ Working age population (16-64 years of age).

Among working people, those without disabilities are more likely to work full-time than individuals with disabilities regardless of the limitation severity (Figure 3.7), and very little changed in this regard between 2004 and 2019. In 2004, 80 per cent of working people without disabilities worked full-time while it was 69 per cent for those with disabilities (includes limited and strongly limited). These percentages fell during the Great Recession for both groups, but in 2019 they returned to similar pre-recession levels.

Working people with disabilities with a strong limitation are less likely to work fulltime than those with limitations only. With the exception of 2011, there was no 
change between 2004 and 2019 in those working full-time by severity level: it was 62-63 per cent for people with strong limitations in 2019 and 70 per cent for those with limitations only, although still lower than for those without disabilities.

FIGURE 3.7 FULL-TIME WORK BY DISABILITY STATUS AND SEVERITY: 2004-2019 (\%)

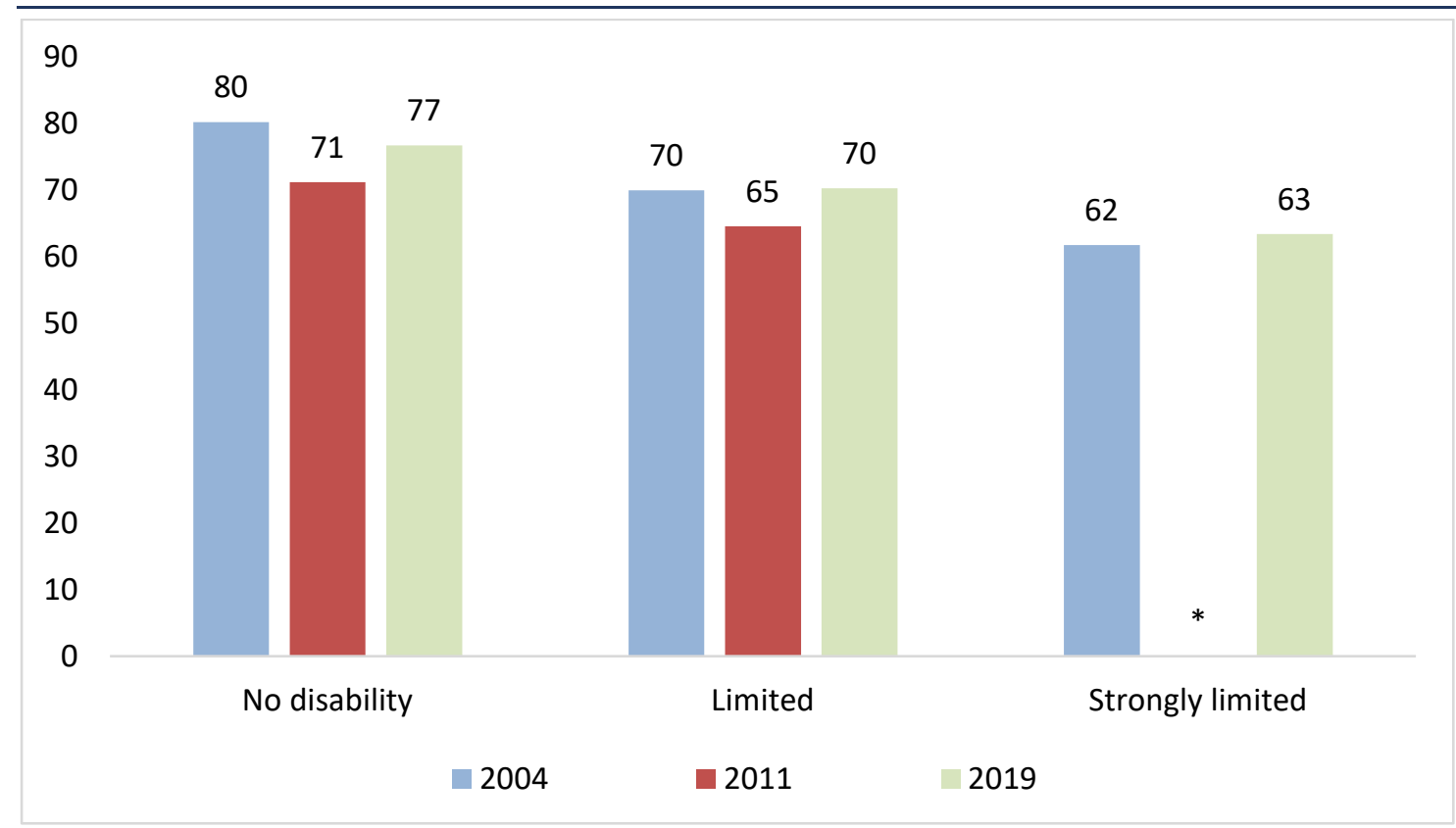

Sources: SILC 2004-2011-2019.

Note: Working age population (16-64 years of age).

* The percentage cannot be reported as the number of observations does not comply with CSO statistical disclosure rules.

In Figure 3.8 we report the occupational gradients for working people with and without disabilities.

The largest occupational groups for people without disabilities are 'Managers and administrators and professionals' and 'Other'. With the exception of 2011, 'Managers and administrators and professionals' represent approximately one-fifth of occupations (21 per cent in 2004 and 23 per cent in 2019) and 'other' one-quarter of occupations ( 24 per cent in 2004 and 25 per cent in 2019). The corresponding figures for people with disabilities are 12 per cent and 16 per cent in 2011 and 2019 for 'Managers and administrators and professionals', and 32 per cent in 2011 and 2019 for 'other'. The percentage distribution across the other occupations is quite even and narrow and there is very little difference too by disability status. Thus, there are fewer people with disabilities in higher occupations (Managers and admin and professional) and more in the lower occupations (Plant and machine operatives), with very little change over time in these proportions. 
FIGURE 3.8 OCCUPATION BY DISABILITY: SILC 2004-2019 (\%)

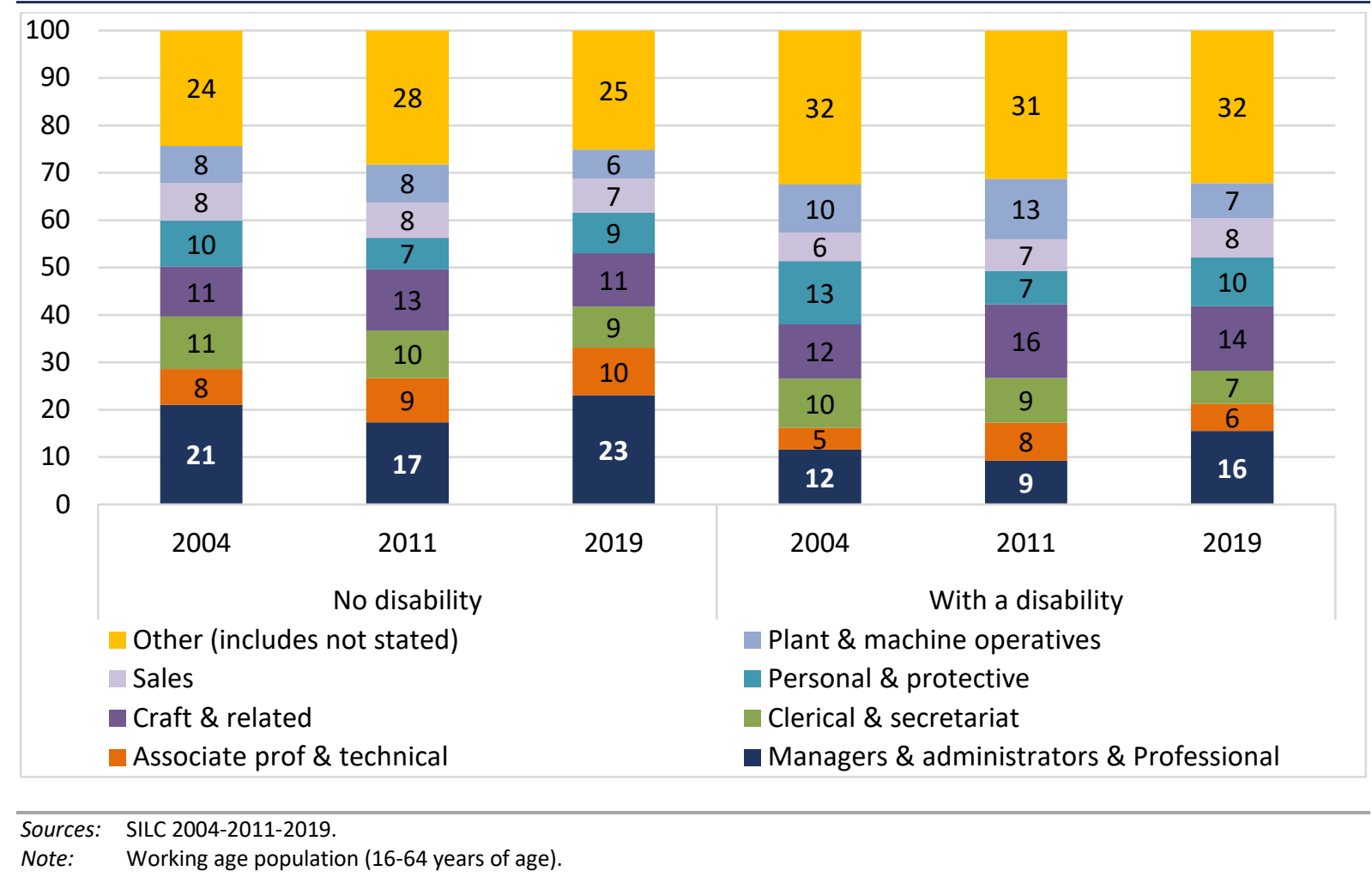

As seen previously in this chapter (Figures 3.2 and 3.3), the older age profile of those with disabilities can explain their under-representation among the top occupations in comparison with people without disabilities because they have lower levels of education. For this reason, we compare in Figure 3.9 the proportion of people with the same education level that are in managerial positions. At the lowest level of education and compared to people with disabilities, there is a slightly greater proportion of people without disabilities in managerial positions. It varies from 13-17 per cent for the former while it is 16-19 per cent for the latter. We observe for both groups smaller percentages of those with low levels of educational attainment being in a managerial position, and this has fallen over time. Interestingly, for people with higher levels of education the gap between people with and without disabilities in managerial positions was quite large in 2004. Indeed, the proportion of people without disabilities in a managerial position was 40 per cent while it was 30 per cent for those with disabilities. However, the gap narrowed over time, and it was 35 per cent for both groups in 2019. 
FIGURE 3.9 MANAGERIAL POSITION FOR WORKING PEOPLE BY DISABILITY: SILC 2004$2019(\%)$

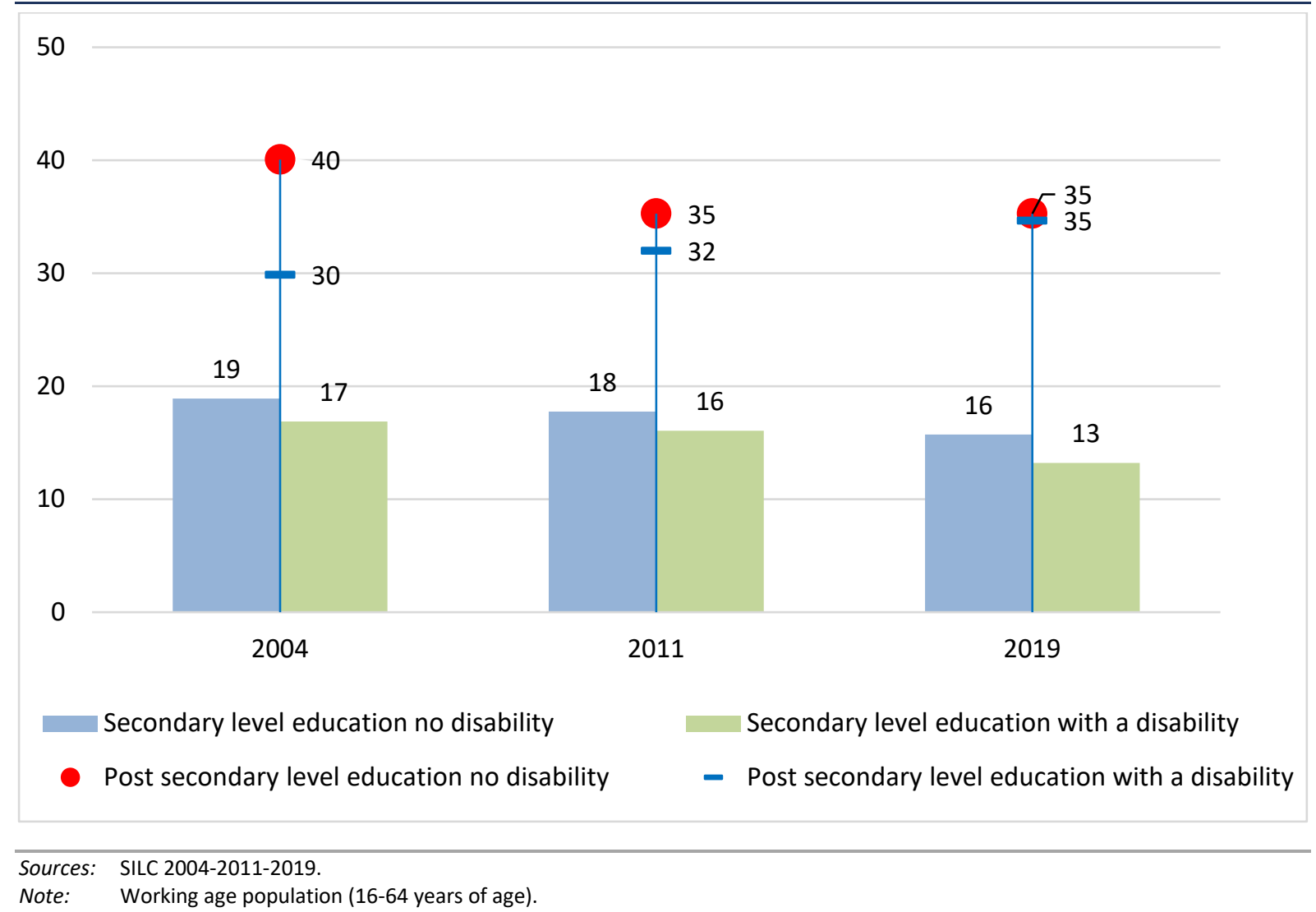

\subsection{JOB SATISFACTION}

Every year, the SILC survey includes an ad hoc module that collects information on a special topic. ${ }^{11}$ In 2013 there was a module on well-being, which was repeated and expanded in 2018 to also examine material deprivation and housing difficulties. Both modules included a question asking people to score their job satisfaction, with the score varying from 0 (not at all satisfied) to 10 (completely satisfied). ${ }^{12}$ In Figure 3.10, we report mean job satisfaction by disability status and gender over time.

Overall, in both 2013 and 2018, people reported having positive job satisfaction, with mean values for people with and without disabilities above the mid-point value of 5. Job satisfaction has also increased over time, and females tend to report higher levels of job satisfaction.

With regards to disability status, those without disabilities report higher levels of job satisfaction compared to those with disabilities. The gap in job satisfaction between males without and with disabilities has increased slightly between 2013

11 The ad hoc module is implemented through regulations by the European Commission. All EU countries participating in the EU-SILC implement these ad hoc modules with their regular annual SILC surveys.

12 The interpretation of the job satisfaction results has to be treated with caution due to the relative high proportion of missing values ( 36 per cent in 2013 and 38 per cent in 2018). 
and 2018. However, while there was also a gap between females by disability status in 2013, the gap reversed in 2018 as females with disabilities reported much higher mean job satisfaction than their counterparts without disabilities.

FIGURE 3.10 MEAN JOB SATISFACTION BY GENDER AND DISABILITY STATUS: SILC 2013-2018 (\%)

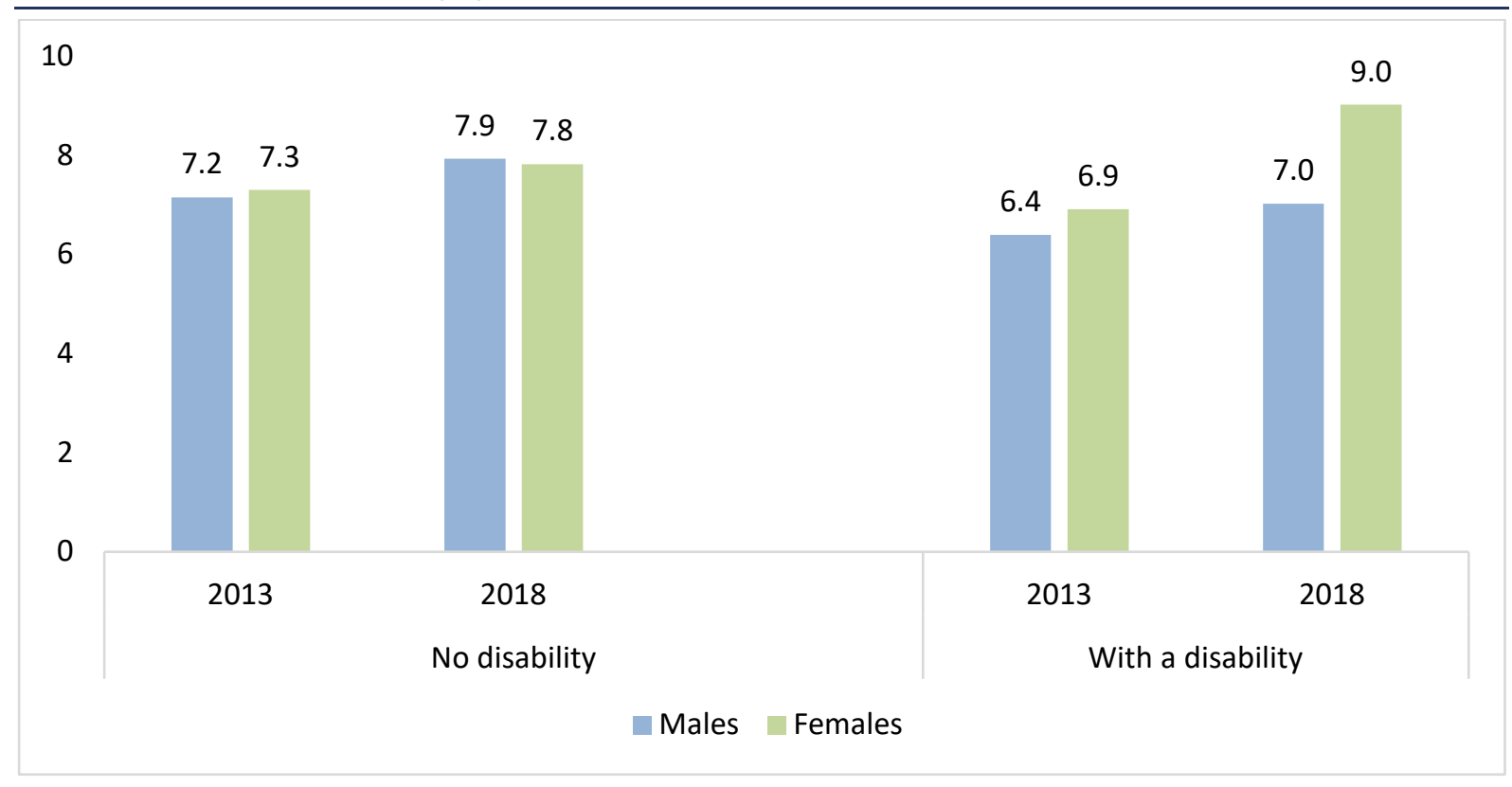

Sources: SILC 2004-2011-2019.

Note: $\quad$ Working age population (16-64 years of age).

\subsection{DISABILITY AND POVERTY}

The Irish government uses several instruments to monitor poverty and social exclusion. It also sets poverty targets, as enshrined in the recent document Roadmap for Social Inclusion 2020-2025 (DEASP, 2020). There are three main poverty measures that the government uses: At Risk of Poverty (AROP), basic deprivation and consistent poverty. The AROP measure identifies individuals living in a household with an income below 60 per cent of the national median equivalised household disposable income. ${ }^{13}$ The measure of basic deprivation captures the inability for people in a household to afford two or more of 11 basic goods and services. ${ }^{14}$ The consistent poverty measure is an overlap of the AROP and basic deprivation poverty measures. Specifically, people are living in consistent poverty if they are living in a household with an income below 60 per cent of the

13 We use the national scale where the first adult (person aged 14 and over) gets a value of 1 , any additional adults a value of 0.66 and each child (aged less than 14) gets a value of 0.36 . The equivalised household income is the total disposable household income divided by the total number of 'equivalent adults'. The total disposable household income is the total gross household income minus tax and social insurance contributions.

14 The 11 items are: unable to afford two pairs of strong shoes; a warm waterproof overcoat; new (not second-hand) clothes; a meal with meat, chicken or fish (or vegetarian equivalent) every second day; a roast joint or its equivalent once a week; no heating at some stage in the last year through lack of money; being able to keep the home adequately warm; unable to buy presents for family or friends at least once a year; to replace any worn out furniture; to have family or friends for a drink or meal once a month; a morning, afternoon or evening out in the last fortnight for entertainment. 
national median household income and are lacking two or more basic goods and services.

In Figure 3.11 we report the prevalence of poverty across the three poverty measures. Looking first at the AROP (income poor) instrument, with the exception of 2011 we see that the AROP for people with disabilities is twice that of people without. It was respectively 32 per cent and 15 per cent in 2004 and 23 per cent and 11 per cent in 2019..$^{15}$

In 2004, before the economic crisis, the level of deprivation was slightly lower than the AROP for all people regardless of disability status but, at the same time, it was higher for people with disabilities. The negative impact of the Great Recession on people's standard of living was such that the level of deprivation increased quite substantially for all groups. Specifically, it increased to 22 per cent and 36 per cent respectively for people without and with disabilities. However, during the recovery period, while the deprivation rate for people without disabilities fell by 8 percentage points to stand at 14 per cent in 2019, it stayed at the same level for people with disabilities. Thus, unlike for people without disabilities, those with a disability did not benefit from the economic recovery. Previous research found also that the employment rate gap between people with and without disabilities narrowed during the recession period (McGinnity et al. 2014).

Finally, with the exception of 2011, people with disabilities are around three times more likely to experience consistent poverty than people without. For both groups, the consistent poverty rate in 2019 is almost identical to that in 2004. In 2019, it was 13 per cent for people with disabilities and 4 per cent for those without. 


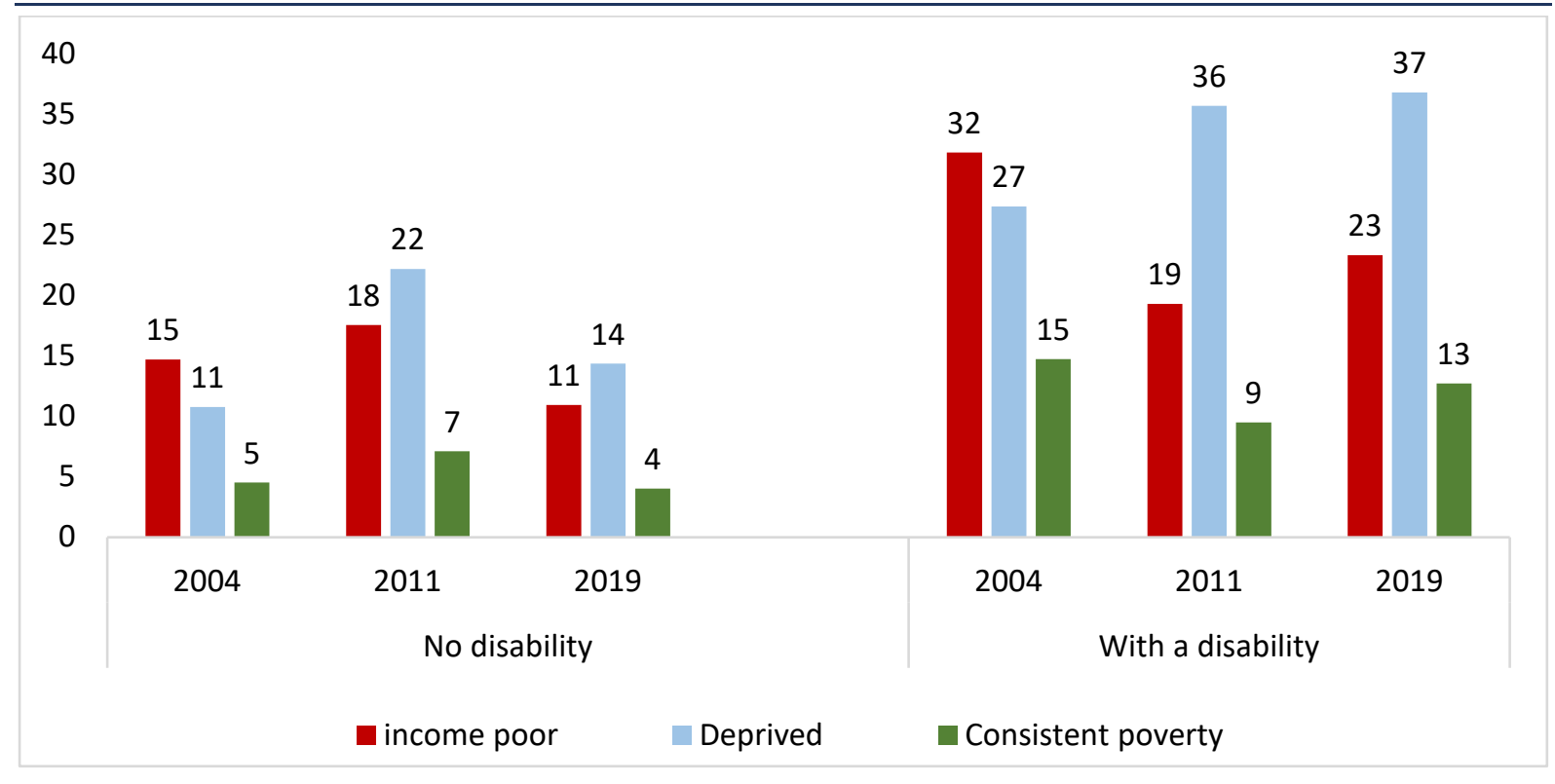

Sources: SILC 2004-2011-2019.

Note: Working age population (16-64 years of age).

As we can see in Figure 3.12, regardless of disability status, working people have lower deprivation than unemployed or inactive people but with some variation among working people. Indeed, regardless of disability status, people working part-time are experiencing deprivation rates that are one-and-a-half to over two times the deprivation rates of people working full-time. Moreover, working status does not protect people with disabilities from poverty to the same extent as people without. Indeed, over the period, the deprivation rate for working people with disabilities is at least twice that of working people without disabilities and this is true for both full-time and part-time workers. In the most recent year, in 2018, the rate was 7 per cent for full-time workers without disabilities while it was 16 per cent for full-time workers with disabilities. It was respectively 15 per cent for parttime workers without disabilities and 26 per cent for part-time workers with disabilities. More striking is that the deprivation rates for full-time workers with disabilities was much higher than for part-time workers without disabilities in 2004 and was identical in 2018.

The deprivation gap by disability also persists for people that are unemployed or inactive. Moreover, the deprivation rate for unemployed or inactive people with disabilities increased consistently over the time period examined, going from 34 per cent in 2004 to 42 per cent in 2019. With the exception of 2011, when the deprivation gap is the lowest between those with and without disabilities that are unemployed/inactive, the deprivation rate for this group with disabilities is almost twice that of their counterparts without. In fact, in 2019 the deprivation rate for unemployed/inactive people without disabilities was slightly lower than working people with disabilities. 


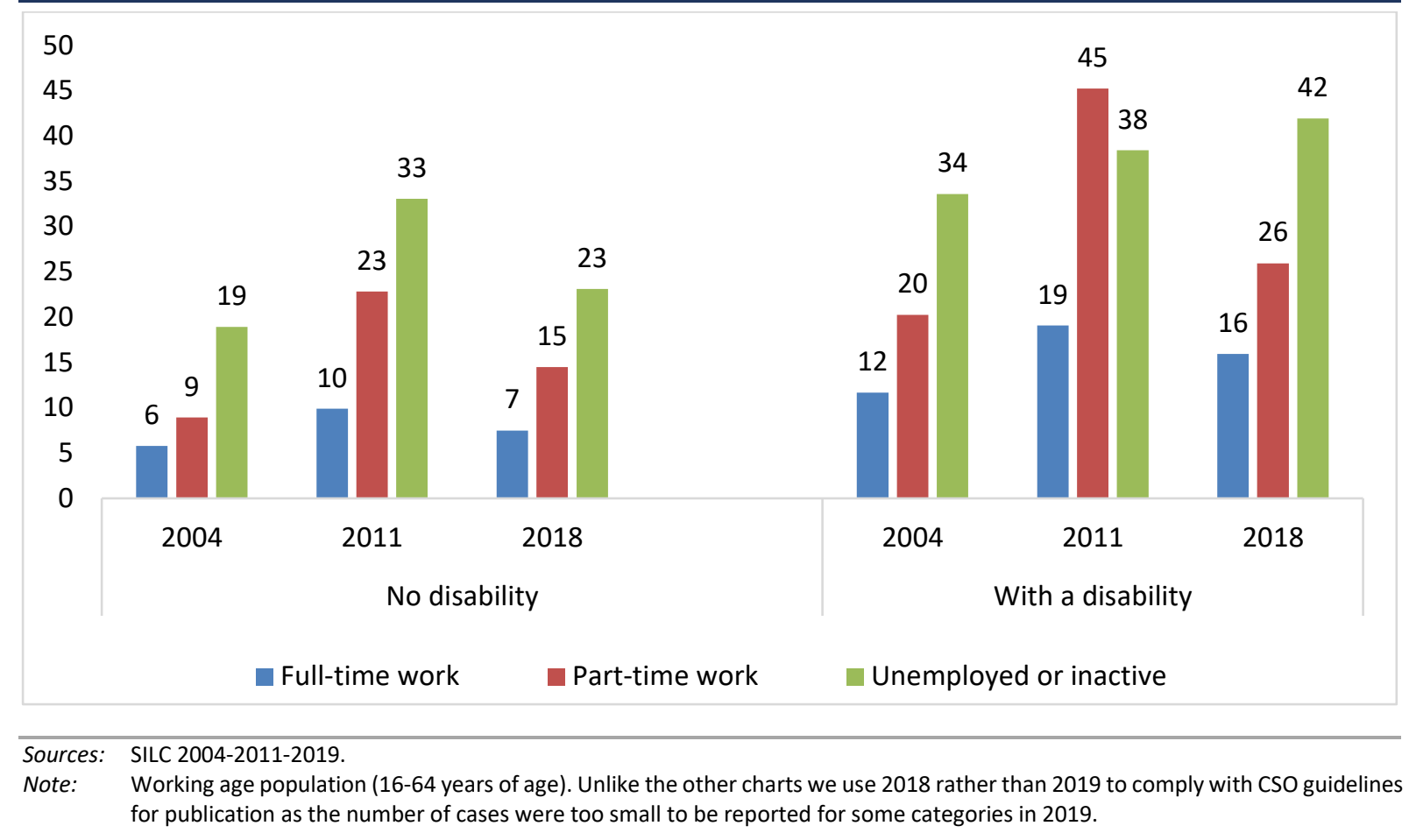

\subsection{SUMMARY}

The SILC data analysis showed that the proportion of people with disabilities has been relatively stable between 2004 and 2019: it went from 15 per cent to 13 per cent, with very little difference by gender or by level of difficulty.

In relation to educational attainment, we found that the proportion of people with at least a post-secondary education level increased between 2004 and 2019 regardless of disability. However, in spite of this increase, the education gap for higher education between people without disabilities and those with increased over time, going from 13 percentage points in 2004 to 18 percentage points in 2019. The education gap persisted even when we focussed on the younger age group of people aged 16 to 34 .

An examination of the respondents' principal economic status over the period (2004 to 2019) showed that while over two-thirds of individuals without disabilities were working, it was only a third for those with disabilities. Moreover, while the proportion of people at work fell during the Great Recession regardless of disability status, the 2019 figures suggest that people with disabilities did not benefit from the economic recovery to the same extent as those without, as they were not back at their pre-recession employment levels by 2019 .

Focusing on working people, the SILC analysis showed that people with disability were less likely to work full-time than those without disabilities. In addition, those with strong limitations were also found to be less likely to work full-time than those with less limitations. People with disabilities were less likely to be in managerial 
positions than those without. However, this gap disappeared over time for those with at least a post-secondary education level.

Finally, the SILC examination found that people with disabilities were much more likely to experience poverty and social exclusion than those without. While being at work helps to reduce considerably the risk of poverty for all people, working people with disabilities were still experiencing higher poverty risks than those working without disabilities. 


\section{Programme for the International Assessment of Adult Competencies (PIAAC): 2012}

\section{$4.1 \quad$ INTRODUCTION}

In this chapter, we use the OECD Programme for the International Assessment of Adult Competencies (PIAAC) survey to assess the literacy and numeracy skills of people aged 16 to 65 with disabilities in Ireland. The information relates to 2012, which is the last time that the PIAAC survey was conducted. We also examine some background characteristics of those people with and without disabilities.

The pilot survey for the PIAAC Cycle 2 was due to take place in Ireland during April 2021 but was cancelled because of the onset of COVID-19: the timetable for Ireland's participation in the 2021-2022 round of PIAAC is currently being reviewed. ${ }^{16}$

\subsection{LITERACY AND NUMERACY}

In asking participants their current employment situation, one response option was 'permanently disabled', ${ }^{17}$ therefore it excludes those who are employed, caring or studying who have a disability. Using this information, we find that participants that reported having a permanent disability in the 2012 Irish PIAAC survey, which was 3.6 per cent of respondents, had lower sores of literacy and numeracy compared to those that did not report having such a disability (Table 4.1). In relation to literacy, all Irish adults had an average score on the literacy scale of $266 .{ }^{18}$ For those that reported a permanent disability, their score was 212 , which compared with 269 for those that did not report having such a disability. With regards to numeracy, the average score for all Irish adults was 255 in 2012. ${ }^{19}$ Those with a permanent disability had a considerably lower average score of 188, which compared with 258 for those with no permanent disability.

For further information, see: https://www.cso.ie/en/surveys/piaaccycle2.

The other response categories were: full-time employed (self-employed, employee), part-time employed (selfemployed, employee), unemployed, student/pupil, apprentice/internship, in retirement or early retirement, in compulsory military or community service, fulfilling domestic tasks or looking after children/family, and other.

This compared to the study average of 270 for all 24 countries that participated in the 2012 PIAAC survey.

This compared to an average score of 266 for all countries that took part in the PIAAC survey in 2012. 
TABLE 4.1 LITERACY AND NUMERACY SKILLS OF WORKING AGE ADULTS IN IRELAND (AVERAGE SCORE): 2012

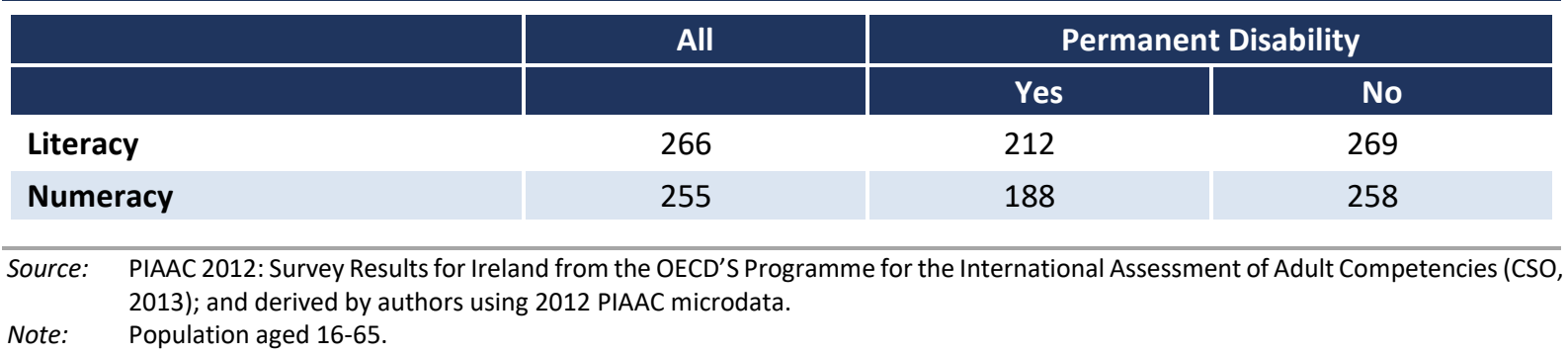

\subsection{BACKGROUND CHARACTERISTICS}

In examining some of the background characteristics of those that reported having a permanent disability (Table 4.2), a higher proportion were male (57 per cent): this compared with 49 per cent of males that did not report having a permanent disability. The average age of those with a permanent disability was 51 compared to 40 among those with no such disability. Eighty-seven per cent of those that reported having a permanent disability were born in Ireland compared to 79 per cent of those without a permanent disability. Part of the reason for this difference will be due to the older age profile of those with a permanent disability. This older age profile of individuals with a permanent disability will also impact some of the other findings presented in this section. For example, their educational attainment compared to those without a permanent disability, and that of their mother and father, computer usage, ever in paid work, etc.

TABLE 4.2 PERSONAL CHARACTERISTICS OF WORKING AGE PEOPLE WITH AND WITHOUT A PERMANENT DISABILITY IN IRELAND: 2012 (\%)

\begin{tabular}{l|l|l|}
\hline & \multicolumn{2}{|c|}{ Permanent Disability } \\
\hline Gender: & Yes & No \\
\hline Male & 56.8 & 48.8 \\
\hline Female & 43.2 & 51.2 \\
\hline Age (average) & 51 & 40 \\
\hline Born in Ireland & 87.3 & 78.7 \\
\hline Presence of children (Yes) & 63 & 60 \\
\hline Native English speaker & 95.6 & 87.0 \\
\hline
\end{tabular}

Source: $\quad$ Results derived by authors using 2012 PIAAC microdata.

Note: $\quad$ Population aged 16-65. 
In relation to educational attainment, ${ }^{20}$ a much larger percentage of those that reported having a permanent disability achieved no higher than lower secondary (Table 4.3): 73 per cent ${ }^{21}$ compared to 26.8 per cent of those without a permanent disability reported having lower secondary or less levels of educational attainment. As with the findings from the Census, this will be partly due to the older age profile of those with a permanent disability, with older age cohorts known to have lower levels of educational attainment compared to their younger counterparts because of increased participation in third-level education over time. ${ }^{22}$

With regard to the educational attainment levels of the parents of respondents, ${ }^{23}$ 82 per cent of the parents of those that reported having a permanent disability had not obtained an upper secondary education: this compared to 49 per cent of the parents of those without a permanent disability. In particular, 85 per cent (86 per cent) of the mothers (fathers) of those with a permanent disability had a secondlevel or less educational attainment compared with 59 per cent ( 63 per cent) of the mothers (fathers) of those without a permanent disability.

Those with a permanent disability were found to have lower levels of computer usage: 47 per cent had never used a computer compared to only 9 per cent of those without a permanent disability.

In relation to educational attainment, the 'low', medium' and 'high' categories are as follows: i) Low: no formal qualification or below ISCED 1, ISCED 1, ISCED 2, and ISCED 3C shorter than two years; ii) Medium: ISCED 3C two years or more, ISCED 3A-B, ISCED 3 (without distinction A-B-C, 2y+), ISCED 4C, ISCED 4A-B, and ISCED 4 (without distinction A-B-C); and iii) High: ISCED 5B, ISCED 5A, Bachelor's degree, ISCED 5A, Master's degree, and ISCED 6. A description of each ISCED level is as follows: i) ISCED 0 Early childhood education ('less than primary' for educational attainment); ii) ISCED 1 Primary education; iii) ISCED 2 Lower secondary education; iv) ISCED 3 Upper secondary education; v) ISCED 4 Post-secondary non-tertiary education; vi) ISCED 5 Short-cycle tertiary education; vii) ISCED 6 Bachelor's or equivalent; viii) ISCED 7 Master's or equivalent; and ix) ISCED 8 Doctoral or equivalent. Given the small number of individuals with a permanent disability that reported having 'medium' and 'high' levels of education attainment (Table 4.3), the percentage with 'low' levels of educational attainment needed to be rounded (to 73 per cent) in order to prevent identification of the percentage of those with 'high' levels of educational attainment (given the small number with such educational attainment and, therefore, the unreliability of the result). 
TABLE 4.3 EDUCATION PROFILE OF PEOPLE WITH AND WITHOUT A PERMANENT DISABILITY IN IRELAND: 2012 (\%)

\begin{tabular}{|l|c|c|}
\hline & \multicolumn{2}{|c|}{ Permanent Disability } \\
\hline & Yes & No \\
\hline Only one language & 93.8 & 91.3 \\
\hline Respondent's educational attainment: & & 26.8 \\
\hline Low & 73.0 & 40.6 \\
\hline Medium & {$[21.0]$} & 32.6 \\
\hline High & $*$ & 21 \\
\hline Age finished education & 18 & \\
\hline Mother's educational attainment: & & 58.8 \\
\hline ISCED 1, 2, and 3C short & 85.4 & \\
\hline Father's educational attainment: & & 62.7 \\
\hline ISCED 1, 2, and 3C short & 85.7 & 48.9 \\
\hline Neither parent has attained upper secondary & 81.6 & 8.8 \\
\hline Never used a computer & 46.7 & \\
\hline
\end{tabular}

Source: $\quad$ Results derived by authors using 2012 PIAAC microdata.

Note: $\quad$ Population aged 16-65

[ ] The percentages in square brackets ([]) are based on smaller numbers of individuals and should be treated with caution.

* Number of respondents used to calculate this percentage is too small for the result to be reliable. Therefore, the result is not presented.

In relation to employment status (Table 4.4), 96 per cent of those that reported having a permanent disability were out of the labour force. ${ }^{24}$ This compared with 63 per cent of those without a permanent disability being in employment and 27 per cent out of the labour force. Nevertheless, 83 per cent of those with a permanent disability indicated that they had been in paid employment at some stage in their life.

TABLE 4.4 EMPLOYMENT STATUS OF PEOPLE WITH AND WITHOUT A PERMANENT DISABILITY IN IRELAND: 2012 (\%)

\begin{tabular}{|l|c|c|}
\hline & \multicolumn{2}{|c|}{ Permanent Disability } \\
\hline & Yes & No \\
\hline Employment Status & $*$ & 63.0 \\
\hline Employed & - & 10.0 \\
\hline Unemployed & 96.0 & 27.0 \\
\hline Out of labour force & - & $*$ \\
\hline Not known & 83.4 & 77.0 \\
\hline Ever in paid work & & \\
\hline
\end{tabular}

Source: $\quad$ Results derived by authors using 2012 PIAAC microdata.

Note: $\quad$ Population aged 16-65. * Number of respondents used to calculate this percentage is too small for the results to be reliable Therefore, the result is not presented. - No observations.

24 By definition this classification excludes people in employment, unemployment, caring or studying. See footnote 17 for more details. 


\subsection{SUMMARY}

When we examined the PIAAC data, we found that individuals that reported having a permanent disability in the 2012 Irish PIAAC survey had lower scores of literacy and numeracy compared to those that did not have such a disability. In relation to literacy, those that reported a permanent disability had an average score of 212 on the literacy scale compared with 269 for those without such a disability. Regarding numeracy, those with a permanent disability had a considerably lower average score of 188 compared with 258 for those with no permanent disability. 



\section{CHAPTER 5}

\section{Census 2011 and 2016}

\section{$5.1 \quad$ INTRODUCTION}

In this chapter, we use the 2011 and 2016 Census data to examine the prevalence of disability in Ireland among the working age population (aged 15-64), overall and also by disability type and everyday difficulties. We then present a brief demographic profile of people with and without disabilities before going on to analyse their education profile. We also examine their labour market characteristics, such as their professional status, main economic status, sector of employment and occupation. We conclude this chapter by analysing the impact of having a disability on a person's likelihood of being in employment - an employee or self-employed, including how this differs by type of disability. We also examine if there is variation in these results by gender.

While we conducted these various examinations using 2011 and 2016 Census data, for the most part the report focuses on the 2016 data. Nevertheless, significant changes that took place between 2011 and 2016 are presented and highlighted in the text.

How respondents are identified as having a disability in the Census data-including the disability type and everyday difficulties data that are collected - was outlined in Chapter 2. It is important to note that the seven disability types in the Census data are not mutually exclusive. In completing the Census questionnaire, a person might indicate that they have blindness or serious visual impairment and also that he/she has an intellectual disability and/or some of the other disability types. Thus, the results presented in this report for each disability type also include individuals that reported having a secondary disability. The same applies with the everyday difficulties categories (i.e. they are not mutually exclusive).

\subsection{PREVALANCE OF DISABILITY}

In 2016, 11.5 per cent of the working age population reported having a disability in Ireland, which is almost identical to the proportion of this group that reported having a disability in the 2011 Census (Table 5.1). The main types of disability among this cohort of individuals were: i) 'difficulty with pain, breathing or any other chronic illness or condition' (5.4 per cent); ii) 'difficulty with basic physical activities such as walking, climbing stairs, reaching, lifting or carrying' (3.6 per cent); iii) a 'psychological or emotional condition' (2.9 per cent); and iv) 'difficulty in learning, remembering or concentrating' ( 2.5 per cent). These were also the main forms of disability reported by the working age population in the 2011 Census. 
TABLE 5.1 PREVALENCE OF DISABILITY AMONG WORKING AGE POPULATION (15-64 YEARS OF AGE) (\%)

\begin{tabular}{|l|r|r|}
\hline & 2011 & 2016 \\
\hline Disability: & & 11.5 \\
\hline Yes & 11.0 & 88.5 \\
\hline No & 89.0 & $3,117,746$ \\
\hline Total: & $3,073,269$ & 0.8 \\
\hline $\begin{array}{l}\text { Type: } \\
\text { Blindness or a serious vision impairment }\end{array}$ & 1.2 \\
\hline $\begin{array}{l}\text { Deafness or a serious hearing impairment } \\
\text { Difficulty with basic physical activities such as walking, climbing } \\
\text { stairs, reaching, lifting or carrying }\end{array}$ & 3.8 & 3.6 \\
\hline $\begin{array}{l}\text { Intellectual disability } \\
\text { Difficulty in learning, remembering or concentrating }\end{array}$ & 1.2 \\
\hline $\begin{array}{l}\text { Psychological or emotional condition } \\
\text { Difficulty with pain, breathing or any other chronic illness or } \\
\text { condition }\end{array}$ & 3.5 & 2.5 \\
\hline \begin{tabular}{l} 
Total: \\
\hline
\end{tabular} & 2.3 & 2.9 \\
\hline
\end{tabular}

Source: $\quad$ Results derived by authors using 2011 and 2016 Census microdata.

In terms of everyday difficulties (Table 5.2), 36 per cent of the working age population that reported having a disability in 2016 indicated that they had difficulty undertaking work/study. This was followed by difficulty undertaking other activities (30.6 per cent), and difficulty going outside (18.7 per cent). Again, similar results were reported in 2011.

TABLE 5.2 PREVALENCE OF EVERYDAY DIFFICULTIES AMONG THOSE WITH DISABILITIES OF WORKING AGE (15-64 YEARS OF AGE): 2011 AND 2016 (\%)

\begin{tabular}{|l|c|c|}
\hline & $\mathbf{2 0 1 1}$ & $\mathbf{2 0 1 6}$ \\
\hline Everyday Difficulties: & & \\
\hline Difficulty dressing & 12.6 & 13.3 \\
\hline Difficulty going outside & 17.3 & 18.7 \\
\hline Difficulty work/study & 35.6 & 36.0 \\
\hline Difficulty other activities & 29.5 & 30.6 \\
\hline Total: & 338,208 & 359,657 \\
\hline
\end{tabular}

Source: $\quad$ Results derived by authors using 2011 and 2016 Census microdata.

As can be seen from Table 5.3, quite a number of people with disabilities tend to have more than one type of disability. Of those people of working age that reported a disability in 2016, over a third had more than one disability. Specifically, 22.4 per cent reported having two disabilities, 8 per cent three disabilities, 3.3 per cent four disabilities and the remaining 1.8 per cent reported having between five and seven disabilities. 
TABLE 5.3 NUMBER OF DISABILITIES AMONG PEOPLE WITH A DISABILITY: 2011 AND 2016 (\%)

\begin{tabular}{|c|c|c|}
\hline Number of Disabilities & $\mathbf{2 0 1 1}$ & $\mathbf{2 0 1 6}$ \\
\hline $\mathbf{1}$ & 66.8 & 64.6 \\
\hline $\mathbf{2}$ & 21.5 & 22.4 \\
\hline $\mathbf{3}$ & 7.1 & 8.0 \\
\hline $\mathbf{4}$ & 2.9 & 3.3 \\
\hline $\mathbf{5}$ & 1.2 & 1.3 \\
\hline $\mathbf{7}$ & 0.3 & 0.3 \\
\hline
\end{tabular}

Source: Results derived by authors using 2011 and 2016 Census microdata.

Note: Working age population (15-64 years of age).

Of those that reported being 'blind or having a serious visual impairment' in 2016, the next most common disabilities for these individuals were 'difficulty with pain, breathing or any other chronic illness or condition' (30.2 per cent), and 'difficulty with basic physical activities such as walking, climbing stairs, reaching, lifting or carrying' (30 per cent). This was also the case for those that reported being 'deaf or having a serious hearing impairment' in the 2016 Census: 23.6 per cent and 20.8 per cent respectively reported 'difficulty with pain, breathing or any other chronic illness or condition', and 'difficulty with basic physical activities such as walking, climbing stairs, reaching, lifting or carrying' as their next most frequent disabilities (Table 5.4).

'Difficulty with pain, breathing or any other chronic illness or condition' was the second most recurrent disability reported by those with 'difficulty with basic physical activities such as walking, climbing stairs, reaching, lifting or carrying', and those with a 'psychological or emotional condition'. For those with an 'intellectual disability', 66.8 per cent reported difficulty in 'learning, remembering or concentrating'; while for those with 'difficulty in learning, remembering or concentrating', the next most common disability was an 'intellectual disability' (34.5 per cent).

TABLE 5.4 PREVALENCE OF SECONDARY DISABILITIES BY DISABILITY TYPE GROUP: 2011 AND 2016 (\%)

\begin{tabular}{|c|c|c|}
\hline & 2011 & 2016 \\
\hline \multicolumn{3}{|l|}{ Blindness or a serious vision impairment: } \\
\hline Deafness or a serious hearing impairment & 12.7 & 13.3 \\
\hline $\begin{array}{l}\text { Difficulty with basic physical activities such as walking, climbing stairs, reaching, } \\
\text { lifting or carrying }\end{array}$ & 28.0 & 30.0 \\
\hline Intellectual disability & 12.2 & 13.2 \\
\hline Difficulty in learning, remembering or concentrating & 19.8 & 21.6 \\
\hline Psychological or emotional condition & 14.6 & 16.8 \\
\hline Difficulty with pain, breathing or any other chronic illness or condition & 28.2 & 30.2 \\
\hline \multicolumn{3}{|l|}{ Deafness or a serious hearing impairment: } \\
\hline Blindness or a serious vision impairment & 8.4 & 8.8 \\
\hline
\end{tabular}


TABLE 5.4 CONTD.

\begin{tabular}{|c|c|c|}
\hline & 2011 & 2016 \\
\hline $\begin{array}{l}\text { Difficulty with basic physical activities such as walking, climbing stairs, reaching, } \\
\text { lifting or carrying }\end{array}$ & 19.7 & 20.8 \\
\hline Intellectual disability & 7.6 & 8.2 \\
\hline Difficulty in learning, remembering or concentrating & 13.7 & 14.9 \\
\hline Psychological or emotional condition & 9.7 & 11.1 \\
\hline Difficulty with pain, breathing or any other chronic illness or condition & 22.6 & 23.6 \\
\hline \multicolumn{3}{|l|}{$\begin{array}{l}\text { Difficulty with basic physical activities such as walking, climbing stairs, reaching, } \\
\text { lifting or carrying: }\end{array}$} \\
\hline Blindness or a serious vision impairment & 6.3 & 6.5 \\
\hline Deafness or a serious hearing impairment & 6.6 & 6.9 \\
\hline Intellectual disability & 11.0 & 11.5 \\
\hline Difficulty in learning, remembering or concentrating & 19.4 & 21.8 \\
\hline Psychological or emotional condition & 15.5 & 18.8 \\
\hline Difficulty with pain, breathing or any other chronic illness or condition & 54.3 & 58.8 \\
\hline \multicolumn{3}{|l|}{ Intellectual disability: } \\
\hline Blindness or a serious vision impairment & 8.2 & 7.9 \\
\hline Deafness or a serious hearing impairment & 7.6 & 7.5 \\
\hline $\begin{array}{l}\text { Difficulty with basic physical activities such as walking, climbing stairs, reaching, } \\
\text { lifting or carrying }\end{array}$ & 32.7 & 31.7 \\
\hline Difficulty in learning, remembering or concentrating & 66.2 & 66.8 \\
\hline Psychological or emotional condition & 32.0 & 33.8 \\
\hline Difficulty with pain, breathing or any other chronic illness or condition & 24.0 & 23.5 \\
\hline \multicolumn{3}{|l|}{ Difficulty in learning, remembering or concentrating: } \\
\hline Blindness or a serious vision impairment & 6.8 & 6.7 \\
\hline Deafness or a serious hearing impairment & 7.0 & 7.0 \\
\hline $\begin{array}{l}\text { Difficulty with basic physical activities such as walking, climbing stairs, reaching, } \\
\text { lifting or carrying }\end{array}$ & 29.8 & 31.1 \\
\hline Intellectual disability & 34.1 & 34.5 \\
\hline Psychological or emotional condition & 29.8 & 33.6 \\
\hline Difficulty with pain, breathing or any other chronic illness or condition & 28.7 & 30.6 \\
\hline \multicolumn{3}{|l|}{ Psychological or emotional condition: } \\
\hline Blindness or a serious vision impairment & 4.9 & 4.5 \\
\hline Deafness or a serious hearing impairment & 4.9 & 4.5 \\
\hline $\begin{array}{l}\text { Difficulty with basic physical activities such as walking, climbing stairs, reaching, } \\
\text { lifting or carrying }\end{array}$ & 23.3 & 23.2 \\
\hline Intellectual disability & 16.1 & 15.0 \\
\hline Difficulty in learning, remembering or concentrating & 29.2 & 29.0 \\
\hline Difficulty with pain, breathing or any other chronic illness or condition & 27.8 & 29.2 \\
\hline \multicolumn{3}{|l|}{ Difficulty with pain, breathing or any other chronic illness or condition: } \\
\hline Blindness or a serious vision impairment & 4.3 & 4.4 \\
\hline Deafness or a serious hearing impairment & 5.1 & 5.2 \\
\hline $\begin{array}{l}\text { Difficulty with basic physical activities such as walking, climbing stairs, reaching, } \\
\text { lifting or carrying }\end{array}$ & 36.8 & 38.8 \\
\hline Intellectual disability & 5.4 & 5.6 \\
\hline Difficulty in learning, remembering or concentrating & 12.6 & 14.2 \\
\hline Psychological or emotional condition & 12.5 & 15.7 \\
\hline
\end{tabular}

Source: $\quad$ Results derived by authors using 2011 and 2016 Census microdata.

Note: $\quad$ Working age population (15-64 years of age). 
Table 5.5 shows the number of disabilities by everyday difficulties. Of the 13.3 per cent of individuals that reported having difficulty dressing in 2016 (Table 5.2), just over 80 per cent had more than one disability. This percentage was smaller for the other everyday difficulties and was the smallest, although still quite large, among the 36 per cent that reported having difficulty attending work, study or college: almost 60 per cent of this group had more than one disability.

TABLE 5.5 NUMBER OF DISABILITIES BY EVERYDAY DIFFICULTIES: 2011 AND 2016 (\%)

\begin{tabular}{|c|c|c|c|c|}
\hline & $\begin{array}{c}\text { Difficulty } \\
\text { Dressing }\end{array}$ & $\begin{array}{c}\text { Difficulty } \\
\text { Going Outside }\end{array}$ & $\begin{array}{c}\text { Difficulty } \\
\text { Work/Study }\end{array}$ & $\begin{array}{c}\text { Difficulty } \\
\text { Other Activities }\end{array}$ \\
\hline Number of Disabilities - 2011: & & & & \\
\hline $\mathbf{1}$ & 21.8 & 27.0 & 44.0 & 38.3 \\
\hline $\mathbf{3}$ & 35.6 & 33.2 & 32.3 & 34.7 \\
\hline $\mathbf{4}$ & 19.3 & 19.7 & 13.4 & 7.5 \\
\hline $\mathbf{5}$ & 13.0 & 11.6 & 6.4 & 3.5 \\
\hline $\mathbf{6}$ & 7.3 & 6.0 & 2.9 & 1.0 \\
\hline $\mathbf{7}$ & 2.2 & 1.7 & 0.8 & 0.3 \\
\hline Total: & 0.8 & 0.7 & 0.3 & 72,580 \\
\hline $\mathbf{1}$ & 28,650 & 39,479 & 87,367 & 35.3 \\
\hline $\mathbf{2}$ & & & & 35.2 \\
\hline $\mathbf{3}$ & 19.2 & 25.1 & 40.3 & 16.3 \\
\hline $\mathbf{4}$ & 36.1 & 33.6 & 33.3 & 8.2 \\
\hline $\mathbf{5}$ & 20.5 & 21.0 & 15.2 & 3.6 \\
\hline $\mathbf{7}$ & 14.1 & 12.3 & 7.2 & 1.0 \\
\hline
\end{tabular}

Source: Results derived by authors using 2016 Census microdata.

Note: Working age population (15-64 years of age).

\subsection{DEMOGRAPHIC PROFILE}

We can see from Table 5.6 that there was no gender difference among the working age population with and without disabilities in 2016, but the former were older: 50.8 per cent were aged 45 to 64 compared to 34.6 per cent of those without disabilities falling into this age bracket. ${ }^{25}$

A larger percentage of individuals without disabilities reported that their health was good/very good: 93 per cent compared to 55.3 per cent among those with disabilities. Slightly larger percentages of people with disabilities classified their ethnicity as White and nationality as being Irish in 2016. A smaller percentage of people with disabilities were married compared to those without disabilities, while 
a higher proportion were divorced/separated. There was no difference in the geographic locations dwelt in by those people with and without disabilities. ${ }^{26}$

TABLE 5.6 DEMOGRAPHIC PROFILE OF PEOPLE WITH AND WITHOUT DISABILITIES: 2016 (\%)

\begin{tabular}{|c|c|c|}
\hline & \multicolumn{2}{|c|}{2016} \\
\hline & No Disability & Disability \\
\hline \multicolumn{3}{|l|}{ Gender: } \\
\hline Male & 49.5 & 49.3 \\
\hline Female & 50.5 & 50.7 \\
\hline \multicolumn{3}{|l|}{ Age: } \\
\hline $15-19$ & 10.0 & 7.9 \\
\hline $20-24$ & 9.0 & 6.9 \\
\hline $25-34$ & 22.0 & 14.7 \\
\hline $35-44$ & 24.5 & 19.7 \\
\hline $45-54$ & 19.7 & 23.2 \\
\hline $55-64$ & 14.9 & 27.6 \\
\hline \multicolumn{3}{|l|}{ Health: } \\
\hline Good/Very Good & 93.0 & 55.3 \\
\hline Fair & 3.5 & 33.1 \\
\hline Bad/Very Bad & 0.2 & 10.4 \\
\hline Not Stated & 3.3 & 1.1 \\
\hline \multicolumn{3}{|l|}{ Ethnicity: } \\
\hline White & 91.4 & 95.5 \\
\hline Other & 5.5 & 3.7 \\
\hline Not Stated & 3.1 & 0.9 \\
\hline \multicolumn{3}{|l|}{ Nationality: } \\
\hline Irish & 82.4 & 88.3 \\
\hline Non-Irish & 16.1 & 11.1 \\
\hline Not Stated & 1.5 & 0.7 \\
\hline \multicolumn{3}{|l|}{ Marital Status: } \\
\hline Single & 46.7 & 48.5 \\
\hline Married & 46.7 & 38.5 \\
\hline Divorced/Separated & 5.3 & 10.6 \\
\hline Widowed & 1.2 & 2.3 \\
\hline \multicolumn{3}{|l|}{ Geographic Location: } \\
\hline Border & 7.9 & 7.9 \\
\hline West & 9.4 & 8.9 \\
\hline Mid-West & 9.7 & 10.5 \\
\hline
\end{tabular}

26 Some of the demographic findings observed in this section for individuals with disabilities, specifically their selfreported general health status, nationality, ethnicity and marital status, may be due to their older age profile. Nevertheless, in an econometric model that we estimated to examine the factors associated with having a disability, these characteristics were each found to have an independent impact from age on being disabled. Specifically, having fair or bad/very bad general health, and being Irish, White, and single were each found to have a positive impact on being disabled separately from the positive impact of being older. Results available from the authors on request. 
TABLE 5.6 CONTD.

\begin{tabular}{|l|c|c|}
\hline & \multicolumn{2}{|c|}{2016} \\
\hline South-East & No Disability & Disability \\
\hline South-West & 8.5 & 9.4 \\
\hline Dublin & 14.4 & 14.7 \\
\hline Mid-East & 29.8 & 28.3 \\
\hline Midland & 14.4 & 14.1 \\
\hline
\end{tabular}

Source: Results derived by authors using 2016 Census microdata.

Note: Working age population (15-64 years of age).

\subsection{EDUCATION PROFILE}

In examining the educational attainment levels of the working age population with and without disabilities, ${ }^{27}$ the first point to note is that a much smaller percentage of those with disabilities have a third-level qualification: 29.6 per cent in 2016 compared to 47.0 per cent among those without disabilities (Table 5.7). There was an increase in the percentage of people with disabilities that had a third-level qualification between 2011 and 2016: almost a 6 percentage point increase (from 24.0 to 29.6 per cent), with the numbers with a primary or lower qualification decreasing by this amount over this time period (from 24.2 to 18.2 per cent).

TABLE 5.7 EDUCATIONAL ATTAINMENT: 2011 AND 2016 (\%)

\begin{tabular}{|l|c|c|c|c|}
\hline & \multicolumn{2}{|c|}{2011} & \multicolumn{2}{c|}{2016} \\
\hline & No Disability & Disability & No Disability & Disability \\
\hline Primary or Lower & 7.5 & 24.2 & 5.0 & 18.2 \\
\hline Lower Secondary & 16.0 & 21.8 & 13.0 & 20.3 \\
\hline Upper Secondary & 31.3 & 26.0 & 29.2 & 27.7 \\
\hline Third-level & 41.3 & 24.0 & 47.0 & 29.6 \\
\hline Not Stated & 3.8 & 4.0 & 5.8 & 4.2 \\
\hline
\end{tabular}

Source: $\quad$ Results derived by authors using 2011 and 2016 Census microdata.

Note: $\quad$ Working age population (15-64 years of age) that have ceased education.

${ }^{1}$ This includes those with a Further Education and Training (FET) qualification.

Part of the explanation for why those with disabilities do not have higher levels of educ ational attainment could be due to their older age profile (see Section 3.2), whom we know have lower levels of education compared to more recent generations. However, even when we examine educational attainment levels by age cohort in 2016 (Table 5.8), we can see that a much smaller percentage of young people (aged 15 to 29) with disabilities had a third-level qualification: 30.8 per cent compared to 46.8 per cent among those without disabilities. They also had higher levels of primary or lower qualifications: 12.5 per cent compared to 2.4 per cent among people without disabilities. This third-level education gap among young

27 In line with the CSO, only those that have ceased education are contained in the educational attainment and Field of Study statistics. 
people with and without disabilities in 2016 is almost identical to that among their

older counterparts (Table 5.8). ${ }^{28}$

TABLE 5.8 EDUCATIONAL ATTAINMENT BY AGE COHORT: 2016 (\%)

\begin{tabular}{l|c|c|}
\hline & \multicolumn{2}{|c|}{$\mathbf{1 5 - 2 9}$ Years of Age } \\
\hline & No Disability & Disability \\
\hline Primary or lower & 2.4 & 12.5 \\
\hline Lower secondary & 7.5 & 15.3 \\
\hline Upper Secondary & 34.8 & 37.5 \\
\hline Third-level & 46.8 & 30.8 \\
\hline Not Stated & 8.4 & 3.9 \\
\hline & & $30-64$ Years of Age \\
\hline & No Disability & Disability \\
\hline Primary or lower & 5.5 & 19.0 \\
\hline Lower secondary & 14.2 & 20.9 \\
\hline Upper Secondary & 28.1 & 26.3 \\
\hline Third-level & 47.0 & 29.5 \\
\hline Not Stated & 5.2 & 4.3 \\
\hline Source: Results derived by authors using 2016 Census microdata. & \\
Note: & \multicolumn{2}{|c|}{ Working age population (15-64 years of age) that have ceased education. } \\
\hline
\end{tabular}

There is variation in educational attainment levels by disability type (Table 5.9). The percentage of those with a primary or lower qualification has fallen across all disability types between 2011 and 2016, while the proportion with a third-level qualification has increased. However, there is substantial variation in the fall/ increase in these two education levels across all disability type groups.

We can see from Table 5.9 that only 6 per cent of those with an 'intellectual disability' reported having a third-level qualification in 2016. This is only an increase of 1.6 percentage points on the 2011 figure. Those with 'difficulty in learning, remembering or concentrating' also reported low levels of third-level education (16.6 per cent). Those with 'difficulty with pain, breathing or any other chronic illness or condition' (32.2 per cent), a 'psychological or emotional condition' (29.2 per cent), and 'deafness or a serious hearing impairment' (28.6 per cent) report the highest levels of third-level educational attainment. Nevertheless, the percentages are still somewhat lower compared to individuals with no disabilities (47 per cent). 
TABLE 5.9 EDUCATIONAL ATTAINMENT BY DISABILITY TYPE: 2011 AND 2016 (\%)

\begin{tabular}{|c|c|c|c|c|c|c|c|c|}
\hline & $\begin{array}{c}\text { No } \\
\text { Disability }\end{array}$ & $\begin{array}{l}\text { Blindness or } \\
\text { a serious } \\
\text { vision } \\
\text { impairment }\end{array}$ & $\begin{array}{l}\text { Deafness or } \\
\text { a serious } \\
\text { hearing } \\
\text { impairment }\end{array}$ & $\begin{array}{l}\text { Difficulty with basic } \\
\text { physical activities such as } \\
\text { walking, climbing stairs, } \\
\text { reaching, lifting or carrying }\end{array}$ & $\begin{array}{l}\text { Intellectual } \\
\text { Disability }\end{array}$ & $\begin{array}{l}\text { Difficulty in } \\
\text { learning, } \\
\text { remembering or } \\
\text { concentrating }\end{array}$ & $\begin{array}{l}\text { Psychological or } \\
\text { emotional } \\
\text { condition }\end{array}$ & $\begin{array}{l}\text { Difficulty with pain, } \\
\text { breathing or any } \\
\text { other chronic illness } \\
\text { or condition }\end{array}$ \\
\hline \multicolumn{9}{|l|}{ 2011: } \\
\hline Primary or Lower & 7.5 & 27.1 & 25.8 & 31.7 & 59.7 & 40.8 & 24.7 & 23.2 \\
\hline Lower Secondary & 16.0 & 19.6 & 22.2 & 23.7 & 16.4 & 21.5 & 21.7 & 21.2 \\
\hline Upper Secondary & 31.3 & 25.7 & 23.9 & 23.6 & 11.2 & 20.0 & 27.3 & 25.7 \\
\hline Third-level & 41.3 & 22.7 & 23.7 & 16.3 & 4.4 & 12.3 & 22.7 & 26.5 \\
\hline Not Stated & 3.8 & 4.9 & 4.4 & 4.7 & 8.3 & 5.5 & 3.6 & 3.4 \\
\hline \multicolumn{9}{|l|}{ 2016: } \\
\hline Primary or Lower & 5.0 & 21.3 & 19.5 & 24.6 & 53.9 & 34.1 & 18.4 & 16.7 \\
\hline Lower Secondary & 13.0 & 19.4 & 21.8 & 23.6 & 16.9 & 20.7 & 19.7 & 20.2 \\
\hline Upper Secondary & 29.2 & 26.9 & 25.5 & 26.4 & 14.1 & 22.9 & 28.8 & 27.2 \\
\hline Third-level & 47.0 & 27.1 & 28.6 & 20.1 & 6.0 & 16.6 & 29.2 & 32.2 \\
\hline Not Stated & 5.8 & 5.2 & 4.7 & 5.3 & 9.0 & 5.8 & 3.8 & 3.7 \\
\hline
\end{tabular}

Source: Results derived by authors using 2011 and 2016 Census microdata.

Note: Working age population (15-64 years of age) that have ceased education. 
When we examine the fields of study pursued by people with disabilities in $2016,{ }^{29}$ we can see that the areas chosen are quite similar to those without disabilities (Table 5.10). The top fields are social sciences, business and law (27.6 per cent), engineering, manufacturing and construction (13.9 per cent), arts and humanities (11.7 per cent) and health (10.6 per cent).

TABLE $5.10 \quad$ FIELD OF STUDY: $2016(\%)$

\begin{tabular}{|l|c|c|}
\hline & No Disability & Disability \\
\hline Education & 8.8 & 7.3 \\
\hline Arts and Humanities & 7.9 & 11.7 \\
\hline Social Sciences, Business and Law & 30.7 & 27.6 \\
\hline Science, Mathematics, Statistics & 5.1 & 4.7 \\
\hline Computing & 5.4 & 5.5 \\
\hline Engineering, Manufacturing and Construction & 15.6 & 13.9 \\
\hline Agriculture and Veterinary & 2.6 & 2.4 \\
\hline Health & 10.3 & 10.6 \\
\hline Social Services & 3.0 & 4.5 \\
\hline Services (including other subjects) & 6.6 & 7.1 \\
\hline Not Stated & 4.0 & 4.8 \\
\hline
\end{tabular}

Source: Results derived by authors using 2016 Census microdata.

Note: Working age population (15-64 years of age) with a third-level qualification (education ceased).

When we examine the fields of study pursued by disability type in $2016^{30}$ (Table 5.11), we can see that the main courses undertaken across all disability types are the same: social sciences, business and law, engineering, manufacturing and construction, arts and humanities, and health. 
TABLE 5.11 FIELD OF STUDY BY DISABILITY TYPE: 2016 (\%)

\begin{tabular}{|c|c|c|c|c|c|c|c|c|}
\hline & $\begin{array}{c}\text { No } \\
\text { Disability }\end{array}$ & $\begin{array}{l}\text { Blindness or } \\
\text { a serious } \\
\text { vision } \\
\text { impairment }\end{array}$ & $\begin{array}{l}\text { Deafness or } \\
\text { a serious } \\
\text { hearing } \\
\text { impairment }\end{array}$ & $\begin{array}{l}\text { Difficulty with basic } \\
\text { physical activities } \\
\text { such as walking, } \\
\text { climbing stairs, } \\
\text { reaching, lifting or } \\
\text { carrying }\end{array}$ & $\begin{array}{c}\text { Intellectual } \\
\text { Disability }\end{array}$ & $\begin{array}{l}\text { Difficulty in } \\
\text { learning, } \\
\text { remembering or } \\
\text { concentrating }\end{array}$ & $\begin{array}{l}\text { Psychological } \\
\text { or emotional } \\
\text { condition }\end{array}$ & $\begin{array}{l}\text { Difficulty with } \\
\text { pain, breathing or } \\
\text { any other chronic } \\
\text { illness or } \\
\text { condition }\end{array}$ \\
\hline Education & 8.8 & 6.2 & 7.6 & 6.9 & 4.3 & 5.4 & 6.6 & 7.8 \\
\hline Arts and Humanities & 7.9 & 11.2 & 9.2 & 10.0 & 13.9 & 12.7 & 16.7 & 10.7 \\
\hline Social Sciences, Business and Law & 30.7 & 28.8 & 27.8 & 26.1 & 19.8 & 23.7 & 28.2 & 27.5 \\
\hline Science, Mathematics, Statistics & 5.1 & 4.6 & 4.1 & 3.4 & 4.3 & 4.0 & 5.3 & 4.8 \\
\hline Computing & 5.4 & 6.1 & 5.1 & 4.7 & 5.7 & 6.1 & 5.8 & 5.3 \\
\hline $\begin{array}{l}\text { Engineering, Manufacturing and } \\
\text { Construction }\end{array}$ & 15.6 & 15.7 & 19.0 & 15.0 & 14.8 & 15.7 & 10.2 & 13.5 \\
\hline Agriculture and Veterinary & 2.6 & 2.6 & 2.6 & 2.3 & 4.2 & 3.4 & 1.8 & 2.2 \\
\hline Health & 10.3 & 8.2 & 8.9 & 10.9 & 5.8 & 7.9 & 9.4 & 12.4 \\
\hline Social Services & 3.0 & 3.7 & 4.0 & 5.6 & 5.5 & 5.2 & 4.6 & 4.6 \\
\hline Services (including other subjects) & 6.6 & 6.5 & 6.6 & 8.0 & 10.1 & 9.0 & 7.1 & 6.9 \\
\hline Not Stated & 4.0 & 6.6 & 5.3 & 7.2 & 11.6 & 6.8 & 4.3 & 4.4 \\
\hline
\end{tabular}

Source: $\quad$ Results derived by authors using 2016 Census microdata.

Note: Working age population (15-64 years of age) with a third-level qualification (education ceased). 


\subsection{COMPUTER AND INTERNET ACCESS}

Given that we are moving towards a more digitalised society, we are able to examine personal computer (PC) usage and internet access with the Census data. When we do this, we can see from Table 5.12 that a smaller percentage of people of working age with disabilities used a PC, and also had access to the internet, in 2016: ${ }^{31} 66.5$ per cent used a PC compared to 76 per cent of people without disabilities, while the corresponding figures for internet access were 77.6 per cent and 86.8 per cent, respectively.

TABLE 5.12 PERSONAL COMPUTER (PC) USAGE AND INTERNET ACCESS: 2016 (\%)

\begin{tabular}{l|c|c|}
\hline PC Usage: & No Disability & Disability \\
\hline Yes & 76.0 & 66.5 \\
\hline No & 18.5 & 27.7 \\
\hline Not Stated & 5.5 & 5.9 \\
\hline Broadband Internet Access: & No Disability & Disability \\
\hline Yes & 78.9 & 69.4 \\
\hline Yes, Other than Broadband & 7.9 & 8.2 \\
\hline No & 8.1 & 17.1 \\
\hline Not Stated & 5.2 & 5.4 \\
\hline Source: Results derived by authors using 2016 Census microdata. & & \\
Note: $\quad$ Working age population (15-64 years of age). & & \\
\hline
\end{tabular}

As can be seen from Table 5.13, some of these differences are due to the older age profile of people with disabilities. Specifically, when we examine PC usage among those aged 15-24, we can see that the gap in usage between those with and without disabilities is much smaller compared to their older counterparts aged 55-64: 3.6 percentage points compared to 14.1 percentage points. The gap in internet access is also much smaller among the younger age cohort with and without disabilities. 
TABLE 5.13 PERSONAL COMPUTER (PC) USAGE AND INTERNET ACCESS BY AGE COHORT: $2016(\%)$

\begin{tabular}{|c|c|c|}
\hline & \multicolumn{2}{|c|}{ 15-24 Years of Age } \\
\hline & No Disability & Disability \\
\hline \multicolumn{3}{|l|}{ PC Usage: } \\
\hline Yes & 76.4 & 72.8 \\
\hline No & 18.1 & 21.7 \\
\hline \multirow[t]{2}{*}{ Not Stated } & 5.4 & 5.5 \\
\hline & No Disability & Disability \\
\hline \multicolumn{3}{|l|}{ Broadband Internet Access: } \\
\hline Yes & 82.1 & 79.1 \\
\hline Yes, Other than Broadband & 7.3 & 7.8 \\
\hline No & 5.6 & 8.1 \\
\hline \multirow[t]{3}{*}{ Not Stated } & 5.0 & 5.0 \\
\hline & \multicolumn{2}{|c|}{ 55-64 Years of Age } \\
\hline & No Disability & Disability \\
\hline \multicolumn{3}{|l|}{ PC Usage: } \\
\hline Yes & 75.4 & 61.3 \\
\hline No & 19.1 & 32.4 \\
\hline \multirow[t]{2}{*}{ Not Stated } & 5.6 & 6.3 \\
\hline & No Disability & Disability \\
\hline \multicolumn{3}{|l|}{ Broadband Internet Access: } \\
\hline Yes & 74.0 & 61.8 \\
\hline Yes, Other than Broadband & 7.4 & 7.4 \\
\hline No & 13.4 & 25.0 \\
\hline Not Stated & 5.2 & 5.8 \\
\hline
\end{tabular}

Source: $\quad$ Results derived by authors using 2016 Census microdata.

Note: Working age population (15-64 years of age).

When we examine PC usage and internet access by disability type (Table 5.14), a smaller percentage of those with an intellectual disability had access to a PC in 2016 (55.7 per cent) compared to the other disability types. The same is true for internet access: it is lower among those with an intellectual disability (65.5 per cent). ${ }^{32}$ As with the overall results, some of these disability type results will be due to the older age profile of people with disabilities. 
TABLE 5.14 PERSONAL COMPUTER (PC) AND INTERNET ACCESS BY DISABILITY TYPE: 2016 (\%)

\begin{tabular}{|c|c|c|c|c|c|c|c|c|}
\hline & $\begin{array}{c}\text { No } \\
\text { Disability }\end{array}$ & $\begin{array}{l}\text { Blindness } \\
\text { or a serious } \\
\text { vision } \\
\text { impairment }\end{array}$ & $\begin{array}{l}\text { Deafness or } \\
\text { a serious } \\
\text { hearing } \\
\text { impairment }\end{array}$ & $\begin{array}{l}\text { A difficulty with basic } \\
\text { physical activities such as } \\
\text { walking, climbing stairs, } \\
\text { reaching, lifting or carrying }\end{array}$ & $\begin{array}{l}\text { Intellectual } \\
\text { Disability }\end{array}$ & $\begin{array}{l}\text { Difficulty in } \\
\text { learning, } \\
\text { remembering or } \\
\text { concentrating }\end{array}$ & $\begin{array}{l}\text { Psychological } \\
\text { or emotional } \\
\text { condition }\end{array}$ & $\begin{array}{l}\text { Difficulty with } \\
\text { pain, breathing or } \\
\text { any other chronic } \\
\text { illness or } \\
\text { condition }\end{array}$ \\
\hline \multicolumn{9}{|l|}{ PC Usage: } \\
\hline Yes & 76.0 & 61.1 & 66.9 & 60.7 & 55.7 & 59.9 & 62.3 & 67.7 \\
\hline No & 18.5 & 31.6 & 28.0 & 32.4 & 32.4 & 30.6 & 29.3 & 27.1 \\
\hline Not Stated & 5.5 & 7.3 & 5.1 & 6.9 & 6.9 & 9.6 & 8.4 & 5.2 \\
\hline \multicolumn{9}{|l|}{ Broadband Internet Access: } \\
\hline Yes & 78.9 & 64.6 & 69.3 & 63.5 & 58.7 & 63.3 & 65.7 & 70.1 \\
\hline Yes, other than Broadband & 7.9 & 7.7 & 8.0 & 8.1 & 6.8 & 7.9 & 8.2 & 8.4 \\
\hline No & 8.1 & 20.9 & 18.2 & 22.1 & 22.2 & 19.7 & 18.1 & 16.7 \\
\hline Not Stated & 5.2 & 6.8 & 4.5 & 6.4 & 12.3 & 9.2 & 8.0 & 4.8 \\
\hline
\end{tabular}

Source: Results derived by authors using 2016 Census microdata.

Note: Working age population (15-64 years of age) that have ceased education 


\subsection{LABOUR MARKET CHARACTERISTICS}

In 2016, a third of the working age people with disabilities indicated that their main economic status was in employment (Table 5.15). This compares with two-thirds of those without disabilities. Almost 13 per cent of people with disabilities reported being unemployed in 2016 compared to 9 per cent of those without disabilities. There was very little change in these two economic status categories among people with disabilities between 2011 and 2016. A slightly larger percentage were unemployed in 2011, but the fall in the proportion unemployed between then and 2016 was not as large as it was among people without disabilities ( 2 percentage points compared to 4 percentage points among those without disabilities).

TABLE 5.15 MAIN ECONOMIC STATUS: 2011 AND 2016 (\%)

\begin{tabular}{|c|c|c|c|c|}
\hline & \multicolumn{2}{|c|}{2011} & \multicolumn{2}{|c|}{2016} \\
\hline & No Disability & Disability & No Disability & Disability \\
\hline Working & 60.6 & 31.2 & 66.2 & 33.9 \\
\hline Unemployed & 13.6 & 14.6 & 9.0 & 12.6 \\
\hline Student & 13.8 & 9.3 & 14.1 & 11.0 \\
\hline Retired & 2.2 & 4.5 & 2.1 & 4.0 \\
\hline All Others ${ }^{1}$ & 9.9 & 40.4 & 8.7 & 38.5 \\
\hline
\end{tabular}

Source: Results derived by authors using 2011 and 2016 Census microdata.

Note: Working age population (15-64 years of age).

1 'All Others' captures those looking after home/family, those unable to work due to permanent sickness or disability and 'others': these are the other principal economic status category options on the Census questionnaire, which are merged into 'all others' in the Census microdata.

When we examine main economic status by disability type (Table 5.16), we can see that only 14.7 per cent of individuals with an 'intellectual disability' were working in 2016. A small percentage of those with 'difficulty with basic physical activities such as walking, climbing stairs, reaching, lifting or carrying' (18.1 per cent) and 'difficulty in learning, remembering or concentrating' (20.7 per cent) were also in employment in 2016. On the other hand, a larger proportion of those that reported having 'deafness or a serious hearing impairment' (45.7 per cent) or having 'blindness or a serious vision impairment' (34 per cent) were working. Similar results are observed in 2011, in terms of the disability types that were more or less likely to be in employment. 
TABLE 5.16 MAIN ECONOMIC STATUS BY DISABILITY TYPE: 2011 AND 2016 (\%)

\begin{tabular}{|c|c|c|c|c|c|c|c|}
\hline & $\begin{array}{l}\text { Blindness or a } \\
\text { serious vision } \\
\text { impairment }\end{array}$ & $\begin{array}{l}\text { Deafness or a } \\
\text { serious hearing } \\
\text { impairment }\end{array}$ & $\begin{array}{l}\text { Difficulty with basic physical } \\
\text { activities such as walking, } \\
\text { climbing stairs, reaching, } \\
\text { lifting or carrying }\end{array}$ & $\begin{array}{l}\text { Intellectual } \\
\text { Disability }\end{array}$ & $\begin{array}{l}\text { Difficulty in } \\
\text { learning, } \\
\text { remembering or } \\
\text { concentrating }\end{array}$ & $\begin{array}{l}\text { Psychological } \\
\text { or emotional } \\
\text { condition }\end{array}$ & $\begin{array}{l}\text { Difficulty with } \\
\text { pain, breathing or } \\
\text { any other chronic } \\
\text { illness or condition }\end{array}$ \\
\hline \multicolumn{8}{|l|}{ 2011: } \\
\hline Working & 32.6 & 41.3 & 17.5 & 15.0 & 20.0 & 21.8 & 31.3 \\
\hline Unemployed & 15.9 & 15.5 & 11.3 & 11.2 & 16.2 & 15.6 & 12.5 \\
\hline Student & 8.5 & 5.1 & 3.2 & 16.4 & 19.2 & 7.9 & 6.2 \\
\hline Retired & 5.1 & 7.7 & 6.3 & 1.5 & 2.4 & 2.7 & 5.0 \\
\hline All others & 37.9 & 30.3 & 61.8 & 55.9 & 42.2 & 52.0 & 45.0 \\
\hline \multicolumn{8}{|l|}{ 2016: } \\
\hline Working & 34.0 & 45.7 & 18.1 & 14.7 & 20.7 & 25.6 & 34.0 \\
\hline Unemployed & 13.8 & 12.7 & 11.0 & 11.1 & 14.0 & 14.3 & 10.7 \\
\hline Student & 9.7 & 5.2 & 3.7 & 20.1 & 21.7 & 12.1 & 6.8 \\
\hline Retired & 4.3 & 7.2 & 5.9 & 1.3 & 2.2 & 2.5 & 4.6 \\
\hline All others & 38.2 & 29.2 & 61.3 & 52.9 & 41.5 & 45.7 & 43.9 \\
\hline
\end{tabular}

Source: Results derived by authors using 2011 and 2016 Census microdata.

Note: Working age population (15-64 years of age) in employment. 
When we examine the professional status of working age people with and without disabilities in 2016 (Table 5.17), we can see that there is no significant difference in the percentages that are employees (approximately $85 / 86$ per cent) or selfemployed (approximately 14/15 per cent). In addition, there has been no significant change in these figures between 2011 and 2016.

TABLE 5.17 PROFESSIONAL STATUS: 2011 AND 2016 (\%)

\begin{tabular}{l|c|c|c|c}
\hline & \multicolumn{2}{|c|}{2011} & \multicolumn{2}{c}{2016} \\
\hline & No Disability & Disability & No Disability & Disability \\
\hline Employee & 83.9 & 83.0 & 85.5 & 84.7 \\
\hline Self-employed & 15.8 & 16.5 & 14.4 & 14.8 \\
\hline Assisting relative & 0.3 & 0.5 & 0.2 & 0.4 \\
\hline
\end{tabular}

Source: Results derived by authors using 2011 and 2016 Census microdata.

Note: Working age population (15-64 years of age) in employment.

However, there is some variation when we examine professional status by disability type (Table 5.18). In particular, in 2016 only 6.4 per cent of working age people with an intellectual disability were self-employed compared to $14.8 \mathrm{per}$ cent of all people with disabilities (Table 5.17). This was also the case in 2011. On the other hand, a higher percentage of people who reported having deafness or a serious hearing impairment in 2016 were self-employed (19.1 per cent) compared to the average figure for all people with and without disabilities.

It is also interesting to note that larger percentages of those with an 'intellectual disability' (92.6 per cent), with a 'psychological or emotional condition' (87.9 per cent), and that had 'difficulty with learning, remembering or concentrating' (86.9 per cent) were employees in 2016 compared to those with no disabilities (85.5 per cent). 
TABLE 5.18 PROFESSIONAL STATUS BY DISABILITY TYPE: 2011 AND 2016 (\%)

\begin{tabular}{|c|c|c|c|c|c|c|c|c|}
\hline & No Disability & $\begin{array}{l}\text { Blindness or a } \\
\text { serious vision } \\
\text { impairment }\end{array}$ & $\begin{array}{l}\text { Deafness or } \\
\text { a serious } \\
\text { hearing } \\
\text { impairment }\end{array}$ & $\begin{array}{l}\text { Difficulty with basic } \\
\text { physical activities such as } \\
\text { walking, climbing stairs, } \\
\text { reaching, lifting or carrying }\end{array}$ & $\begin{array}{c}\text { Intellectual } \\
\text { Disability }\end{array}$ & $\begin{array}{l}\text { Difficulty in } \\
\text { learning, } \\
\text { remembering or } \\
\text { concentrating }\end{array}$ & $\begin{array}{l}\text { Psychological } \\
\text { or emotional } \\
\text { condition }\end{array}$ & $\begin{array}{l}\text { Difficulty with } \\
\text { pain, breathing } \\
\text { or any other } \\
\text { chronic illness } \\
\text { or condition }\end{array}$ \\
\hline \multicolumn{9}{|l|}{ 2011: } \\
\hline Employee & 83.9 & 84.2 & 79.9 & 81.6 & 92.4 & 85.0 & 86.9 & 82.4 \\
\hline Self-Employed & 15.8 & 15.3 & 19.8 & 17.8 & 6.4 & 14.1 & 12.5 & 17.2 \\
\hline Assisting Relative & 0.3 & 0.5 & 0.4 & 0.6 & 1.2 & 0.9 & 0.6 & 0.4 \\
\hline \multicolumn{9}{|l|}{ 2016: } \\
\hline Employee & 85.5 & 85.2 & 80.5 & 83.2 & 92.6 & 86.8 & 87.9 & 84.2 \\
\hline Self-Employed & 14.4 & 14.2 & 19.1 & 16.3 & 6.4 & 12.5 & 11.6 & 15.5 \\
\hline Assisting Relative & 0.2 & [0.6] & 0.4 & 0.6 & 1.1 & 0.7 & 0.5 & 0.4 \\
\hline
\end{tabular}

Source: Results derived by authors using 2011 and 2016 Census microdata.

Note: Working age population (15-64 years of age) in employment. [] The percentages in square brackets ([]) are based on smaller numbers of individuals and should be treated with caution. 
Table 5.19 shows that there is not much variation in the occupational distribution among those of working age with and without disabilities. There has also been no substantial change in this distribution between 2011 and 2016.

TABLE 5.19 OCCUPATIONAL DISTRIBUTION: 2011 AND 2016 (\%)

\begin{tabular}{|c|c|c|c|c|}
\hline & \multicolumn{2}{|c|}{2011} & \multicolumn{2}{|c|}{2016} \\
\hline & No Disability & Disability & No Disability & Disability \\
\hline Managers, Directors, Senior Officials & 8.8 & 7.4 & 8.0 & 6.7 \\
\hline Professional Occupations & 19.0 & 15.5 & 19.5 & 16.3 \\
\hline Associate Professional and Technical Occupations & 11.9 & 10.9 & 11.9 & 11.4 \\
\hline Administrative and Secretarial Occupations & 11.5 & 12.0 & 10.7 & 12.1 \\
\hline Skilled Trades Occupations & 14.0 & 13.6 & 13.5 & 12.8 \\
\hline Caring, Leisure and Other Service Occupations & 7.2 & 8.3 & 7.6 & 9.0 \\
\hline Sales and Customer Service Occupations & 7.4 & 7.9 & 6.9 & 8.1 \\
\hline Process, Plant and Machine Operatives & 7.3 & 7.1 & 7.2 & 6.8 \\
\hline Elementary Occupations ${ }^{1}$ & 8.5 & 10.7 & 8.4 & 10.4 \\
\hline Not Stated & 4.5 & 6.7 & 6.3 & 6.4 \\
\hline $\begin{array}{ll}\text { Source: } & \text { Results derived by authors using } 2011 \text { and } 2016 \text { Census } \\
\text { Note: } & \text { Working age population (15-64 years of age) in employ } \\
& { }^{1} \text { Examples of elementary occupations include farm wor } \\
& \text { and couriers, window cleaners, security guards and rela }\end{array}$ & $\begin{array}{l}\text { crodata. } \\
\text { nt. }\end{array}$ & & 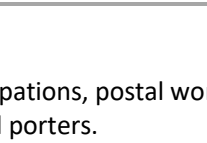 & gers \\
\hline
\end{tabular}

However, there is variation on the basis of disability type (Table 5.20). In particular, those with an intellectual disability were less likely to be managers, directors, or senior officials (2.4 per cent), or in professional occupations (3.8 per cent) or associate professional and technical occupations (5.0 per cent) in $2016 .{ }^{33}$ Instead, they were more likely to be in elementary occupations (19 per cent), sales and customer service occupations (11.3 per cent), and skilled trades occupations (11.3 per cent).

Individuals that had 'deafness or a serious hearing impairment' (7.5 per cent), 'difficulty with pain, breathing or any other chronic illness or condition' (7.4 per cent) or reported having 'blindness or a serious vision impairment' (6.9 per cent) were more likely to hold a manager, director, or senior official position. Individuals with these types of disability were also more represented in professional occupations (14 per cent, 19.3 per cent, and 14 per cent respectively), as were those with a 'psychological or emotional condition' (17.4 per cent), in 2016. Individuals that had 'difficulty with basic physical activities such as walking, climbing stairs, reaching, lifting or carrying' were more likely to be in administrative and secretarial (14.1 per cent) and skilled trades occupations (12.6 per cent), while those with 'difficulty in learning, remembering or concentrating' were more heavily represented in elementary ( 16.1 per cent) and skilled trades (15.6 per cent) occupations. 
TABLE 5.20 OCCUPATION DISTRIBUTION BY DISABILITY TYPE: 2016 (\%)

\begin{tabular}{|c|c|c|c|c|c|c|c|c|}
\hline & $\begin{array}{c}\text { No } \\
\text { Disability }\end{array}$ & $\begin{array}{l}\text { Blindness or a } \\
\text { serious vision } \\
\text { impairment }\end{array}$ & $\begin{array}{l}\text { Deafness or } \\
\text { a serious } \\
\text { hearing } \\
\text { impairment }\end{array}$ & $\begin{array}{l}\text { Difficulty with basic } \\
\text { physical activities such } \\
\text { as walking, climbing } \\
\text { stairs, reaching, lifting } \\
\text { or carrying }\end{array}$ & $\begin{array}{l}\text { Intellectual } \\
\text { Disability }\end{array}$ & $\begin{array}{l}\text { Difficulty in } \\
\text { learning, } \\
\text { remembering or } \\
\text { concentrating }\end{array}$ & $\begin{array}{l}\text { Psychological } \\
\text { or emotional } \\
\text { condition }\end{array}$ & $\begin{array}{l}\text { Difficulty with } \\
\text { pain, breathing } \\
\text { or any other } \\
\text { chronic illness } \\
\text { or condition }\end{array}$ \\
\hline $\begin{array}{l}\text { Managers, Directors, Senior } \\
\text { Officials }\end{array}$ & 8.0 & 6.9 & 7.5 & 5.9 & 2.4 & 4.4 & 5.4 & 7.4 \\
\hline Professional Occupations & 19.5 & 14.0 & 14.0 & 11.9 & 3.8 & 7.6 & 17.4 & 19.3 \\
\hline $\begin{array}{l}\text { Associate Professional and } \\
\text { Technical Occupations }\end{array}$ & 11.9 & 10.3 & 10.7 & 9.6 & 5.0 & 9.1 & 13.3 & 12.1 \\
\hline $\begin{array}{l}\text { Administrative and } \\
\text { Secretarial Occupations }\end{array}$ & 10.7 & 12.5 & 11.6 & 14.1 & 4.7 & 6.6 & 13.9 & 12.7 \\
\hline Skilled Trades Occupations & 13.5 & 14.3 & 17.5 & 12.6 & 11.3 & 15.6 & 8.5 & 11.7 \\
\hline $\begin{array}{l}\text { Caring, Leisure and Other } \\
\text { Service Occupations }\end{array}$ & 7.6 & 8.3 & 8.7 & 9.2 & 7.4 & 10.0 & 9.4 & 9.0 \\
\hline $\begin{array}{l}\text { Sales and Customer Service } \\
\text { Occupations }\end{array}$ & 6.9 & 8.3 & 5.9 & 7.6 & 11.3 & 10.0 & 10.6 & 7.4 \\
\hline $\begin{array}{l}\text { Process, Plant and Machine } \\
\text { Operatives }\end{array}$ & 7.2 & 4.5 & 8.2 & 7.7 & 6.0 & 7.8 & 4.9 & 6.7 \\
\hline Elementary Occupations & 8.4 & 12.6 & 10.4 & 10.6 & 19.0 & 16.1 & 9.7 & 8.8 \\
\hline Not Stated & 6.3 & 8.2 & 5.6 & 10.9 & 29.1 & 12.8 & 6.9 & 5.0 \\
\hline
\end{tabular}

Source: $\quad$ Results derived by authors using 2016 Census microdata.

Note: Working age population (15-64 years of age) in employment. 
As with occupation, there is very little difference in the economic sectors in which those with and without disabilities were employed in 2016 (Table 5.21), and there was no significant change between 2011 and 2016. There is also very little variation in the sectors that individuals with disabilities are employed in by disability type (Table 5.22). In 2016, the main sectors across all disability type groups were retail, health, and industry. ${ }^{34}$

TABLE 5.21 ECONOMIC SECTOR OF EMPLOYMENT: 2011 AND 2016 (\%)

\begin{tabular}{|l|c|c|c|c|}
\hline & \multicolumn{2}{|c|}{$\mathbf{2 0 1 1}$} & \multicolumn{2}{c}{$\mathbf{2 0 1 6}$} \\
\hline & No Disability & Disability & No Disability & Disability \\
\hline Agriculture & 4.3 & 4.8 & 3.8 & 3.8 \\
\hline Industry & 11.9 & 9.7 & 11.7 & 9.8 \\
\hline Construction & 4.9 & 4.0 & 5.2 & 13.4 \\
\hline Retail & 14.6 & 13.8 & 13.3 & 3.9 \\
\hline Transport & 4.3 & 4.3 & 4.0 & 6.2 \\
\hline Hotel & 5.8 & 5.6 & 5.9 & 4.5 \\
\hline Communication & 3.9 & 3.6 & 4.6 & 4.2 \\
\hline Finance & 5.8 & 4.5 & 5.1 & 5.1 \\
\hline Technical & 5.2 & 4.4 & 5.7 & 4.1 \\
\hline Administration & 3.4 & 3.8 & 3.5 & 6.2 \\
\hline Public Administration & 6.3 & 7.2 & 5.3 & 9.1 \\
\hline Education & 9.4 & 9.5 & 8.9 & 13.2 \\
\hline Health & 10.9 & 12.7 & 11.1 & 2.2 \\
\hline Arts & 1.7 & 2.1 & 1.7 & 2.4 \\
\hline Other Services & 2.3 & 2.6 & 2.3 & 7.8 \\
\hline Not Stated & 5.4 & 7.4 & 7.9 & \\
\hline
\end{tabular}

Source: Results derived by authors using 2011 and 2016 Census microdata.

Note: Working age population (15-64 years of age) in employment. 
TABLE 5.22 ECONOMIC SECTOR OF EMPLOYMENT BY DISABILITY TYPE: 2016 (\%)

\begin{tabular}{|c|c|c|c|c|c|c|c|c|}
\hline & $\begin{array}{c}\text { No } \\
\text { Disability }\end{array}$ & $\begin{array}{l}\text { Blindness or a } \\
\text { serious vision } \\
\text { impairment }\end{array}$ & $\begin{array}{l}\text { Deafness or } \\
\text { a serious } \\
\text { hearing } \\
\text { impairment }\end{array}$ & $\begin{array}{l}\text { Difficulty with basic } \\
\text { physical activities such as } \\
\text { walking, climbing stairs, } \\
\text { reaching, lifting or carrying }\end{array}$ & $\begin{array}{l}\text { Intellectual } \\
\text { Disability }\end{array}$ & $\begin{array}{l}\text { Difficulty in } \\
\text { learning, } \\
\text { remembering or } \\
\text { concentrating }\end{array}$ & $\begin{array}{l}\text { Psychological } \\
\text { or emotional } \\
\text { condition }\end{array}$ & $\begin{array}{l}\text { Difficulty with } \\
\text { pain, breathing } \\
\text { or any other } \\
\text { chronic illness } \\
\text { or condition }\end{array}$ \\
\hline Agriculture & 3.8 & 4.2 & 5.4 & 4.2 & 4.0 & 5.0 & 2.3 & 3.4 \\
\hline Industry & 9.8 & 10.5 & 12.0 & 8.8 & 6.9 & 8.9 & 8.2 & 9.6 \\
\hline Construction & 4.2 & 4.8 & 5.9 & 3.8 & 3.0 & 5.1 & 2.5 & 3.9 \\
\hline Retail & 13.4 & 13.0 & 12.3 & 12.6 & 16.4 & 15.0 & 14.0 & 12.8 \\
\hline Transport & 3.9 & 2.5 & 4.4 & 4.7 & 1.6 & 3.5 & 2.9 & 4.2 \\
\hline Hotel & 6.2 & 8.0 & 4.5 & 5.6 & 8.3 & 8.9 & 6.7 & 5.2 \\
\hline Communication & 4.5 & 4.7 & 3.3 & 2.9 & 2.0 & 3.7 & 5.7 & 4.8 \\
\hline Finance & 4.2 & 3.8 & 4.0 & 2.9 & 1.4 & 2.5 & 4.7 & 4.5 \\
\hline Technical & 5.1 & 5.0 & 4.9 & 4.1 & 2.1 & 3.5 & 5.7 & 5.4 \\
\hline Administration & 4.1 & 4.5 & 3.8 & 4.1 & 3.5 & 4.7 & 4.3 & 3.9 \\
\hline Public Administration & 6.2 & 6.6 & 7.2 & 7.0 & 2.6 & 4.2 & 6.3 & 6.5 \\
\hline Education & 9.1 & 7.4 & 8.2 & 8.6 & 6.0 & 6.3 & 9.8 & 10.2 \\
\hline Health & 13.2 & 11.0 & 12.2 & 13.5 & 11.5 & 10.5 & 13.2 & 14.7 \\
\hline Arts & 2.2 & 2.0 & 2.1 & 1.9 & 2.1 & 2.3 & 3.2 & 2.1 \\
\hline Other Services & 2.4 & 2.1 & 2.1 & 2.6 & 1.8 & 2.7 & 2.7 & 2.5 \\
\hline Not Stated & 7.8 & 10.0 & 7.8 & 12.8 & 26.6 & 13.3 & 7.7 & 6.4 \\
\hline
\end{tabular}

Source: Results derived by authors using 2016 Census microdata.

Note: Working age population (15-64 years of age) in employment. 


\subsection{IMPACT OF DISABILITY ON LIKELIHOOD OF BEING AN EMPLOYEE}

Using econometric techniques, in this section of the report we examine the impact that having a disability has on a person's likelihood of being in employment in 2016, overall and by disability type. ${ }^{35}$ We utilise econometric modelling in order to isolate the impact of having a disability on this outcome, separate from the other factors that can affect being employed, such as age, gender, etc.

In this context, we are modelling the choice between two discrete alternatives being in employment or not - and we use a probit model to estimate this binary outcome. We focus on the working population aged 15 to 64, with individuals that are self-employed or assisting relatives excluded from the analysis. ${ }^{36}$ Thus, we are focussing on employees in this examination. In the next section, we look at the impact of having a disability on someone's probability of being self-employed.

We initially ran a specification in which only a dummy variable that captures whether an individual has a disability was included. We then estimated a second specification in which we added self-reported general health; while in a third specification we augmented our model by adding a set of controls to capture the impact of gender, age, ethnicity, nationality, marital status, and geographic location on a person's likelihood of being an employee. ${ }^{37}$ The results from these three estimated specifications are presented in Table $5.23,{ }^{38}$ while the results broken down by gender are given in Table 5.24. We also estimated these three specifications with our disability dummy variable replaced with disability type variables. The results from these models, for all individuals of working age and separately by gender, are presented in Tables 5.25 and $5.26 .{ }^{39}$

Focussing initially on the impact of having a disability on being an employee, we can see from the results presented in Column 1 in Table 5.23 that it has a negative

35 See Appendix Tables A.8 - A.11 for the results for 2011.

36 Self-employed individuals are excluded from the analysis because the labour market faced by this group of workers differs from that of employees, as do, consequently, their behaviours.

37 The estimated coefficients produced through probit regression cannot be interpreted as measuring the impact on the dependent variable, in this case being in employment or not, of a one-unit increase (decrease) in an explanatory variable because of the non-linear nature of the estimation procedure. Given this, marginal effects are calculated after estimating the probit models, using the mean of the explanatory variable as the base, as marginal effects give a measure of the size of the relationship between the dependent (being in employment) and explanatory variable (e.g. disability).

38 Educational attainment was found to be colinear with intellectual disability. This issue prevents us from isolating the impact of having an intellectual disability on someone's likelihood of being in employment; therefore, educational attainment was not included in our estimated models. However, in Appendix Tables A.12 (disability dummy variable) and A.13 (disability type) we have estimated our employee model for 2016 with those with an intellectual disability excluded and educational attainment included. These models were estimated in order to examine the effect that controlling for educational attainment has on the impact of disability status on an individual's likelihood of being an employee. The inclusion of educational attainment either reduces or has no impact on the negative impact that having a disability has on this outcome.

39 Using the 2016 Census data, we also estimated another specification in which the number of disabilities that an individual has was included instead of either a disability dummy variable or disability type dummy variables: it was not possible to include this variable as a separate control in either the disability dummy variable or disability type models because of multicollinearity between the disability variables. As expected, the likelihood of being in employment, employee or self-employed, decreases with increasing number of disabilities (see Appendix Table A.14). 
effect: this trait on its own reduced an individual's probability of being an employee in 2016 by 19 percentage points compared to those with no disability (i.e. the reference category). When we add in a measure of a person's self-reported general health into our model (Column 2), we find that the impact of having a disability on the likelihood of being an employee continues to be negative, but the size of the effect declines to 12 percentage points. The effect declines further to 9.9 percentage points when we control for a range of other factors that can affect someone's likelihood of being an employee (Column 3).

The results for some of the other characteristics examined in specification 3 are worth noting. In particular, males were less likely to be employees in 2016 compared to females (reference category). Compared to people that reported good/very good health, those that indicated that their health was fair or bad/very bad were less likely to be working in 2016. This health effect is separate from the negative impact of having a disability on someone's likelihood of being an employee. Those aged 16-19 and 55-64 were considerably less likely to be working in 2016 compared to those aged 35-44. Finally, while those residing outside of Dublin were less likely to be employees, the largest negative effects were associated with residing in the Border region, the Midland, and the South-East.

TABLE 5.23 IMPACT OF DISABILITY ON A PERSON'S PROBABILITY OF BEING AN EMPLOYEE: 2016 (MARGINAL EFFECTS)

\begin{tabular}{|c|c|c|c|}
\hline & $\begin{array}{l}\text { Disability } \\
\text { (1) }\end{array}$ & $\begin{array}{c}\text { Self-Reported } \\
\text { General Health } \\
\text { (2) }\end{array}$ & $\begin{array}{l}\text { All Characteristics } \\
\text { (3) }\end{array}$ \\
\hline \multirow[t]{2}{*}{ Disability (Ref: No Disability): } & $-0.191 * * *$ & $-0.120 * * *$ & $-0.099 * * *$ \\
\hline & $(0.001)$ & $(0.001)$ & $(0.001)$ \\
\hline \multicolumn{4}{|c|}{ General Health (Ref: Very Good/Good): } \\
\hline \multirow[t]{2}{*}{ Fair } & & $-0.178^{* * *}$ & $-0.139 * * *$ \\
\hline & & $(0.002)$ & $(0.001)$ \\
\hline \multirow[t]{2}{*}{ Bad/Very Bad } & & $-0.283 * * *$ & $-0.239 * * *$ \\
\hline & & $(0.005)$ & $(0.005)$ \\
\hline \multicolumn{4}{|l|}{ Gender (Ref: Female): } \\
\hline \multirow[t]{2}{*}{ Male } & & & $-0.025 * * *$ \\
\hline & & & $(0.001)$ \\
\hline \multicolumn{4}{|l|}{ Age (Ref: Age 35-44): } \\
\hline \multirow[t]{2}{*}{$15-19$} & & & $-0.164 * * *$ \\
\hline & & & $(0.003)$ \\
\hline \multirow[t]{2}{*}{ 20-24 } & & & $-0.020 * * *$ \\
\hline & & & $(0.001)$ \\
\hline \multirow[t]{2}{*}{$25-34$} & & & $0.002 * *$ \\
\hline & & & $(0.001)$ \\
\hline \multirow[t]{2}{*}{ 45-54 } & & & $-0.032 * * *$ \\
\hline & & & $(0.001)$ \\
\hline \multirow[t]{2}{*}{$55-64$} & & & $-0.231 * * *$ \\
\hline & & & $(0.001)$ \\
\hline
\end{tabular}


TABLE 5.23 CONTD.

\begin{tabular}{|c|c|c|c|}
\hline & $\begin{array}{l}\text { Disability } \\
\text { (1) }\end{array}$ & $\begin{array}{c}\text { Self-Reported } \\
\text { General Health } \\
\text { (2) }\end{array}$ & $\begin{array}{c}\text { All Characteristics } \\
\text { (3) }\end{array}$ \\
\hline \multicolumn{4}{|l|}{ Ethnicity (Ref: Other): } \\
\hline \multirow[t]{2}{*}{ White } & & & $0.084 * * *$ \\
\hline & & & $(0.002)$ \\
\hline \multicolumn{4}{|c|}{ Nationality (Ref: Non-Irish): } \\
\hline \multirow[t]{2}{*}{ Irish } & & & $0.008^{* * *}$ \\
\hline & & & $(0.001)$ \\
\hline \multicolumn{4}{|c|}{ Marital Status (Ref: Single): } \\
\hline \multirow[t]{2}{*}{ Married } & & & $0.084 * * *$ \\
\hline & & & $(0.001)$ \\
\hline \multirow[t]{2}{*}{ Divorced/Separated } & & & $0.020 * * *$ \\
\hline & & & $(0.001)$ \\
\hline \multirow[t]{2}{*}{ Widowed } & & & $-0.025^{* * *}$ \\
\hline & & & $(0.002)$ \\
\hline \multicolumn{4}{|c|}{ Geographic Location (Ref: Dublin): } \\
\hline \multirow[t]{2}{*}{ Border } & & & $-0.060 * * *$ \\
\hline & & & $(0.001)$ \\
\hline \multirow[t]{2}{*}{ West } & & & $-0.027^{* * *}$ \\
\hline & & & $(0.001)$ \\
\hline \multirow[t]{2}{*}{ Mid-West } & & & $-0.041 * * *$ \\
\hline & & & $(0.001)$ \\
\hline \multirow[t]{2}{*}{ South-East } & & & $-0.058^{* * *}$ \\
\hline & & & $(0.001)$ \\
\hline \multirow[t]{2}{*}{ South-West } & & & $-0.010 * * *$ \\
\hline & & & $(0.001)$ \\
\hline \multirow[t]{2}{*}{ Mid-East } & & & $-0.023^{* * *}$ \\
\hline & & & $(0.001)$ \\
\hline \multirow[t]{2}{*}{ Midland } & & & $-0.065^{* * *}$ \\
\hline & & & $(0.001)$ \\
\hline Observations & $1,969,148$ & $1,969,148$ & $1,969,148$ \\
\hline Pseudo R-squared & 0.0190 & 0.0319 & 0.0893 \\
\hline
\end{tabular}

Source: $\quad$ Results derived by authors using 2016 Census microdata.

Note: $\quad$ Working age population (15-64 years of age) in employment (employees only). 'Not stated' cases controlled for in estimated specifications. 'Ref' $=$ reference category (i.e. the group against which the derived results are compared with). Standard errors in parentheses; ${ }^{* * *} p<0.01,{ }^{* *} p<0.05,{ }^{*} p<0.1$.

The negative impact of having a disability on being an employee is slightly larger among males (Table 5.24): it reduces their likelihood of being an employee by 
11.1 percentage points compared to 8.9 percentage points for females. ${ }^{40}$ Overall, we can see that having a disability is found to have a negative and significant impact on a person's probability of being an employee in 2016.

TABLE 5.24 IMPACT OF DISABILITY ON A PERSON'S PROBABILITY OF BEING AN EMPLOYEE BY GENDER: 2016 (MARGINAL EFFECTS)

\begin{tabular}{|c|c|c|c|}
\hline & $\begin{array}{l}\text { All } \\
\text { (3) }\end{array}$ & $\begin{array}{l}\text { Males } \\
\text { (3) }\end{array}$ & $\begin{array}{c}\text { Females } \\
\text { (3) }\end{array}$ \\
\hline \multirow[t]{2}{*}{ Disability (Ref: No Disability): } & $-0.099 * * *$ & $-0.111 * * *$ & $-0.089 * * *$ \\
\hline & $(0.001)$ & $(0.002)$ & $(0.002)$ \\
\hline
\end{tabular}

Source: $\quad$ Results derived by authors using 2016 Census microdata.

Note: Working age population (15-64 years of age) in employment (employees only).

Controls for gender, age, ethnicity, nationality, marital status, geographic location, and not stated cases included in estimated specifications. Standard errors in parentheses; *** $p<0.01, * * p<0.05, * p<0.1$.

We find that the impact of having a disability on a person's employment chances varies by type of disability (Table 5.25). In particular, those with a 'psychological or emotional condition' or those that have 'difficulty with basic physical activities such as walking, climbing stairs, reaching, lifting or carrying' are most severely impacted, with these two types of disability reducing a person's likelihood of being an employee by 11.6 and 11.5 percentage points respectively in 2016 (Column 3). The group of individuals that are next most heavily impacted are those with 'difficulty in learning, remembering or concentrating': this type of disability reduced an individual's likelihood of being an employee in 2016 by 9.3 percentage points. For all these disability types, the negative effect was slightly larger among males than females (Table 5.26).

40 We also examined the impact of disability by age cohort and found that the negative impact is larger among those aged 15-19 and 55-64 (see Appendix Table A.15), which is in line with the overall disability model presented in Table 5.23. In addition, we ran separate employment models, employee and self-employed, for people with and without a disability to examine if there was variation in the impact of age for both sub-populations. The results (Appendix Table A.16) show that the negative age effect for those aged 55-64 is marginally greater for those with a disability in both the employee and self-employed model, while the negative age impact for those aged 15-19 is much larger for those with a disability in the self-employment model. 
TABLE 5.25 IMPACT OF DISABILITY TYPE ON A PERSON'S PROBABILITY OF BEING AN EMPLOYEE: 2016 (MARGINAL EFFECTS)

\begin{tabular}{|c|c|c|c|}
\hline & $\begin{array}{l}\text { Disability Type } \\
\text { (1) }\end{array}$ & $\begin{array}{l}\text { Self-Reported } \\
\text { General Health } \\
\text { (2) }\end{array}$ & $\begin{array}{c}\text { All } \\
\text { Characteristics } \\
\text { (3) }\end{array}$ \\
\hline \multicolumn{4}{|l|}{ Disability Type (Ref: No Disability): } \\
\hline \multirow[t]{2}{*}{ Blindness or a serious vision impairment } & $-0.082^{* * *}$ & $-0.061 * * *$ & $-0.047^{* * *}$ \\
\hline & $(0.004)$ & $(0.004)$ & $(0.004)$ \\
\hline \multirow[t]{2}{*}{ Deafness or a serious hearing impairment } & $-0.096 * * *$ & $-0.081 * * *$ & $-0.041^{* * *}$ \\
\hline & $(0.003)$ & $(0.003)$ & $(0.003)$ \\
\hline \multirow[t]{2}{*}{$\begin{array}{l}\text { Difficulty with basic physical activities such } \\
\text { as walking, climbing stairs, reaching, lifting } \\
\text { or carrying }\end{array}$} & $-0.232 * * *$ & $-0.154 * * *$ & $-0.115^{* * *}$ \\
\hline & $(0.003)$ & $(0.003)$ & $(0.003)$ \\
\hline \multirow[t]{2}{*}{ Intellectual Disability } & $-0.063 * * *$ & $-0.057^{* * *}$ & $-0.041 * * *$ \\
\hline & $(0.004)$ & $(0.004)$ & $(0.004)$ \\
\hline \multirow[t]{2}{*}{$\begin{array}{l}\text { Difficulty in learning, remembering or } \\
\text { concentrating }\end{array}$} & $-0.130 * * *$ & $-0.107 * * *$ & $-0.093^{* * *}$ \\
\hline & $(0.003)$ & $(0.003)$ & $(0.003)$ \\
\hline \multirow[t]{2}{*}{ Psychological or emotional condition } & $-0.148 * * *$ & $-0.107^{* * *}$ & $-0.116 * * *$ \\
\hline & $(0.003)$ & $(0.003)$ & $(0.003)$ \\
\hline \multirow[t]{2}{*}{$\begin{array}{l}\text { Difficulty with pain, breathing or any other } \\
\text { chronic illness or condition }\end{array}$} & $-0.068 * * *$ & $-0.012^{* * *}$ & $-0.010 * * *$ \\
\hline & $(0.002)$ & $(0.001)$ & $(0.001)$ \\
\hline \multicolumn{4}{|l|}{ General Health (Ref: Very Good/Good): } \\
\hline \multirow[t]{2}{*}{ Fair } & & $-0.174 * * *$ & $-0.137^{* * *}$ \\
\hline & & $(0.002)$ & $(0.001)$ \\
\hline \multirow[t]{2}{*}{ Bad/Very Bad } & & $-0.227^{* * *}$ & $-0.197^{* * *}$ \\
\hline & & $(0.005)$ & $(0.005)$ \\
\hline \multicolumn{4}{|l|}{ Gender (Ref: Female): } \\
\hline \multirow[t]{2}{*}{ Male } & & & $-0.025^{* * *}$ \\
\hline & & & $(0.001)$ \\
\hline \multicolumn{4}{|l|}{ Age (Ref: Age 35-44): } \\
\hline \multirow[t]{2}{*}{$15-19$} & & & $-0.163^{* * *}$ \\
\hline & & & $(0.003)$ \\
\hline \multirow[t]{2}{*}{$20-24$} & & & $-0.020 * * *$ \\
\hline & & & $(0.001)$ \\
\hline \multirow[t]{2}{*}{$25-34$} & & & $0.002 * *$ \\
\hline & & & $(0.001)$ \\
\hline \multirow[t]{2}{*}{$45-54$} & & & $-0.032 * * *$ \\
\hline & & & $(0.001)$ \\
\hline \multirow[t]{2}{*}{$55-64$} & & & $-0.231 * * *$ \\
\hline & & & $(0.001)$ \\
\hline \multicolumn{4}{|l|}{ Ethnicity (Ref: Other): } \\
\hline \multirow[t]{2}{*}{ White } & & & $0.084^{* * *}$ \\
\hline & & & $(0.002)$ \\
\hline
\end{tabular}


TABLE 5.25 CONTD.

\begin{tabular}{|c|c|c|c|}
\hline & $\begin{array}{c}\text { Disability Type } \\
\text { (1) }\end{array}$ & $\begin{array}{l}\text { Self-Reported } \\
\text { General Health } \\
\text { (2) }\end{array}$ & $\begin{array}{c}\text { All } \\
\text { Characteristics } \\
\text { (3) }\end{array}$ \\
\hline \multicolumn{4}{|c|}{ Nationality (Ref: Non-Irish): } \\
\hline \multirow[t]{2}{*}{ Irish } & & & $0.008 * * *$ \\
\hline & & & $(0.001)$ \\
\hline \multicolumn{4}{|c|}{ Marital Status (Ref: Single): } \\
\hline \multirow[t]{2}{*}{ Married } & & & $0.082 * * *$ \\
\hline & & & $(0.001)$ \\
\hline \multirow[t]{2}{*}{ Divorced/Separated } & & & $0.020 * * *$ \\
\hline & & & $(0.001)$ \\
\hline \multirow[t]{2}{*}{ Widowed } & & & $-0.026 * * *$ \\
\hline & & & $(0.002)$ \\
\hline \multicolumn{4}{|c|}{ Geographic Location (Ref: Dublin): } \\
\hline \multirow[t]{2}{*}{ Border } & & & $-0.060 * * *$ \\
\hline & & & $(0.001)$ \\
\hline \multirow[t]{2}{*}{ West } & & & $-0.027^{* * *}$ \\
\hline & & & $(0.001)$ \\
\hline \multirow[t]{2}{*}{ Mid-West } & & & $-0.040 * * *$ \\
\hline & & & $(0.001)$ \\
\hline \multirow[t]{2}{*}{ South-East } & & & $-0.058 * * *$ \\
\hline & & & $(0.001)$ \\
\hline \multirow[t]{2}{*}{ South-West } & & & $-0.010 * * *$ \\
\hline & & & $(0.001)$ \\
\hline \multirow[t]{2}{*}{ Mid-East } & & & $-0.023^{* * *}$ \\
\hline & & & $(0.001)$ \\
\hline \multirow[t]{2}{*}{ Midland } & & & $-0.065^{* * *}$ \\
\hline & & & $(0.001)$ \\
\hline Observations & $1,969,148$ & $1,969,148$ & $1,969,148$ \\
\hline Pseudo R-squared & 0.0228 & 0.0343 & 0.0911 \\
\hline
\end{tabular}

Source: $\quad$ Results derived by authors using 2016 Census microdata.

Note: Working age population (15-64 years of age) in employment (employees only). 'Not stated' cases controlled for in estimated specifications. Standard errors in parentheses; ${ }^{* * *} p<0.01, * * p<0.05, * p<0.1$. 
TABLE 5.26 IMPACT OF DISABILITY TYPE ON A PERSON'S PROBABILITY OF BEING AN EMPLOYEE BY GENDER: 2016 (MARGINAL EFFECTS)

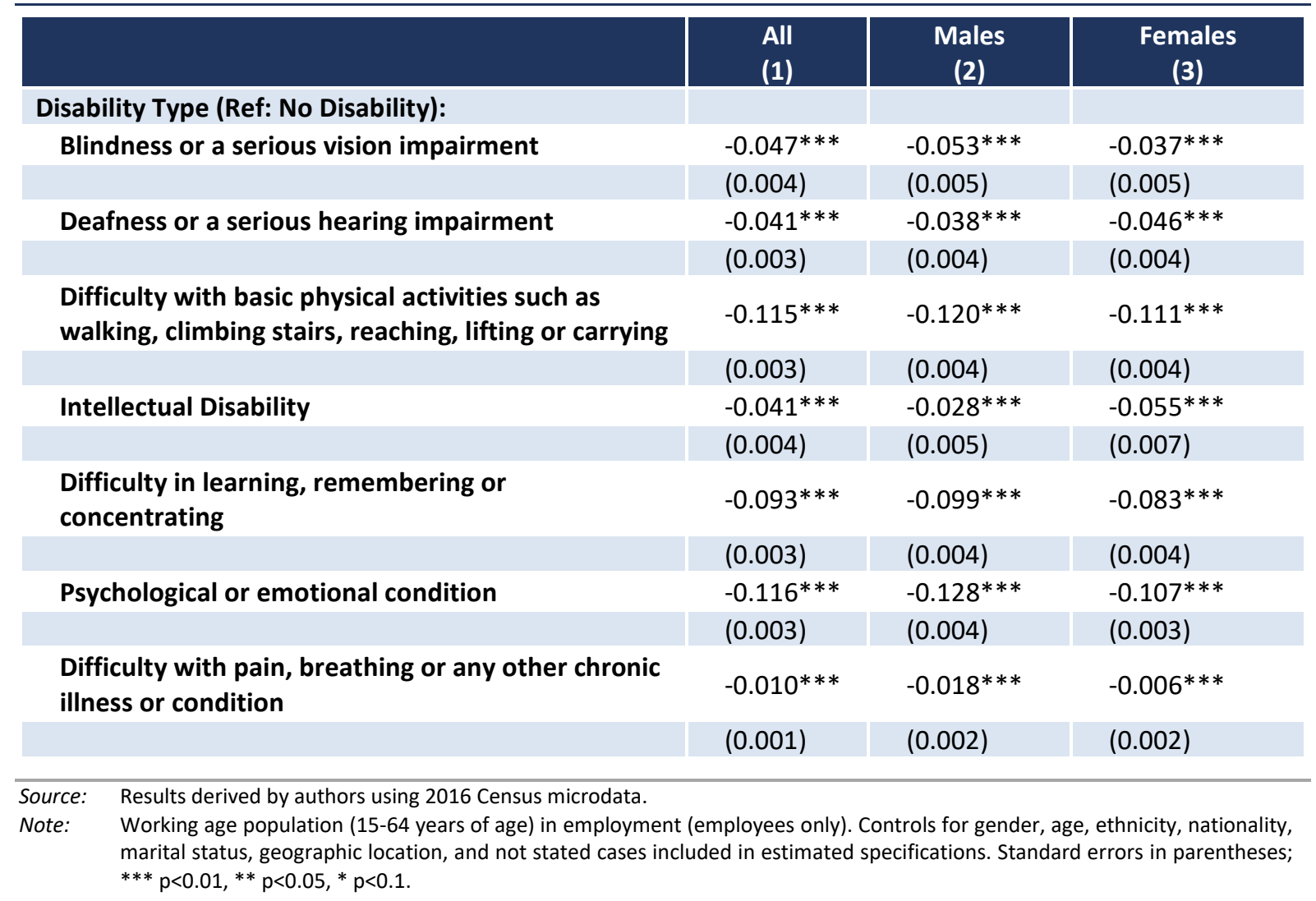

\section{$5.8 \quad$ IMPACT OF DISABILITY ON PROBABILITY OF SELF-EMPLOYMENT}

In this section, we examine the impact of having a disability on an individual's probability of being self-employed in 2016 , overall and by disability type. ${ }^{41}$ As with the employee examination in Section 5.7, we use econometric techniques to undertake this analysis, and also examine the impact separately for males and females.

Controlling for disability on its own, we can see from Table 5.27 that having a disability reduced a person's likelihood of being self-employed in 2016 by 10.7 percentage points. When we include a measure to capture a person's selfreported general health in our model (Column 2), we find that the negative impact of having a disability on self-employment falls to 5.8 percentage points. The impact declines further to 4.6 percentage points when we control for a range of other factors that can affect someone's likelihood of being self-employed (Column 3). When we compare this self-employment analysis with the employee examination

41 See Appendix Tables A.17 - A.20 for the results for 2011. In addition, see Appendix Tables A.21 and A.22 for the disability results (disability dummy variable and disability type) for 2016 when those with an intellectual disability are excluded from the models and educational attainment included. As with the employee model, the inclusion of educational attainment reduces the negativity impact of having a disability on someone's likelihood of being selfemployed, but the reduction is not as big as it is for the employee analysis. 
in Section 5.7 (Table 5.23), we can see that having a disability is not as severe on being self-employed as it is on being an employee.

In relation to some of the other characteristics controlled for in our third specification, we can see that those aged 25-34 are more likely to be self-employed compared to those aged 35-44, whereas all other age categories are less likely to be self-employed. Those resident in the Mid-West and South-West are equally as likely to be self-employed as those from Dublin, whereas those from the Border, South-East, West, Midland and Mid-East are less likely.

TABLE 5.27 IMPACT OF DISABILITY ON A PERSON'S PROBABILITY OF SELF-EMPLOYMENT: 2016 (MARGINAL EFFECTS)

\begin{tabular}{|c|c|c|c|}
\hline & $\begin{array}{c}\text { Disability } \\
\text { (1) }\end{array}$ & $\begin{array}{l}\text { Self-Reported } \\
\text { General Health } \\
\text { (2) }\end{array}$ & $\begin{array}{c}\text { All Characteristics } \\
\text { (3) }\end{array}$ \\
\hline \multirow[t]{2}{*}{ Disability (Ref: No Disability): } & $-0.107 * * *$ & $-0.058 * * *$ & $-0.046 * * *$ \\
\hline & $(0.003)$ & $(0.002)$ & $(0.002)$ \\
\hline \multicolumn{4}{|c|}{ General Health (Ref: Very Good/Good): } \\
\hline \multirow[t]{2}{*}{ Fair } & & $-0.112 * * *$ & $-0.077^{* * *}$ \\
\hline & & $(0.003)$ & $(0.003)$ \\
\hline \multirow[t]{2}{*}{ Bad/Very Bad } & & $-0.196 * * *$ & $-0.150 * * *$ \\
\hline & & $(0.012)$ & $(0.011)$ \\
\hline \multicolumn{4}{|l|}{ Gender (Ref: Female): } \\
\hline \multirow[t]{2}{*}{ Male } & & & $-0.002 *$ \\
\hline & & & $(0.001)$ \\
\hline \multicolumn{4}{|l|}{ Age (Ref: Age 35-44): } \\
\hline \multirow[t]{2}{*}{$15-19$} & & & $-0.128 * * *$ \\
\hline & & & $(0.019)$ \\
\hline \multirow[t]{2}{*}{$20-24$} & & & $-0.014 * * *$ \\
\hline & & & $(0.005)$ \\
\hline \multirow[t]{2}{*}{$25-34$} & & & $0.007 * * *$ \\
\hline & & & $(0.002)$ \\
\hline \multirow[t]{2}{*}{$45-54$} & & & $-0.021 * * *$ \\
\hline & & & $(0.001)$ \\
\hline \multirow[t]{2}{*}{$55-64$} & & & $-0.087 * * *$ \\
\hline & & & $(0.002)$ \\
\hline \multicolumn{4}{|l|}{ Ethnicity (Ref: Other): } \\
\hline \multirow[t]{2}{*}{ White } & & & $0.029 * * *$ \\
\hline & & & $(0.003)$ \\
\hline \multicolumn{4}{|l|}{ Nationality (Ref: Non-Irish): } \\
\hline \multirow[t]{2}{*}{ Irish } & & & $0.036 * * *$ \\
\hline & & & $(0.002)$ \\
\hline \multicolumn{4}{|l|}{ Marital Status (Ref: Single): } \\
\hline \multirow[t]{2}{*}{ Married } & & & $0.041 * * *$ \\
\hline & & & $(0.001)$ \\
\hline
\end{tabular}


TABLE 5.27 CONTD.

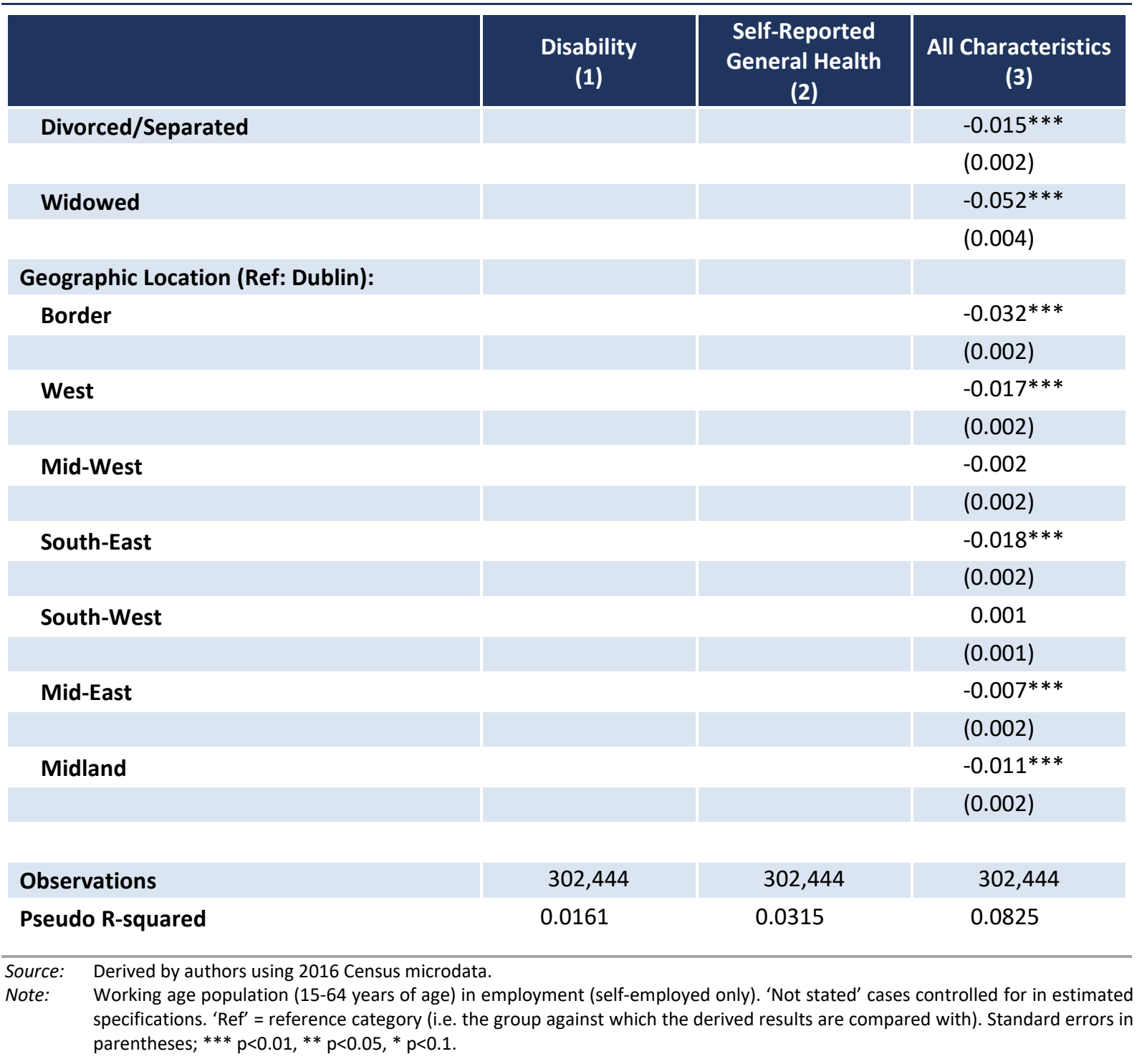

We can see from Table 5.28 that having a disability has a slightly larger negative impact on a male being self-employed than it has for a female.

TABLE 5.28 IMPACT OF DISABILITY ON A PERSON'S PROBABILITY OF SELF-EMPLOYMENT BY GENDER: 2016 (MARGINAL EFFECTS)

\begin{tabular}{l|l|l|l}
\hline & All & Males & \multicolumn{1}{c|}{ Females } \\
\hline Disability (Ref: No Disability): & $-0.046^{* * *}$ & $-0.051^{* * *}$ & $-0.034^{* * *}$ \\
\hline
\end{tabular}

Source: Derived by authors using 2016 Census microdata.

Note: Working age population (15-64 years of age) in employment (self-employed only). Controls for gender, age, ethnicity, nationality, marital status, geographic location and not stated cases included in estimated specifications.

Standard errors in parentheses; $* * * p<0.01, * * p<0.05, * p<0.1$.

Moving on to disability type (Table 5.29), those with a difficulties with basic physical activities such as walking, climbing stairs, reaching, lifting or carrying or a psychological or emotional condition had the lowest likelihood of being selfemployed in 2016: the former were 7 percentage points less likely to be self- 
employed, while those with a psychological or emotional condition were 5.7 percentage points less likely to be self-employed (Column 3). Both of these disabilities had a bigger negative impact for males, as did having blindness or a serious vision impairment and having deafness or a serious hearing impairment (Table 5.30).

TABLE 5.29 IMPACT OF DISABILITY TYPE ON A PERSON'S PROBABILITY OF SELFEMPLOYMENT: 2016 (MARGINAL EFFECTS)

\begin{tabular}{|c|c|c|c|}
\hline & $\begin{array}{l}\text { Disability Type } \\
\text { (1) }\end{array}$ & $\begin{array}{c}\text { Self-Reported } \\
\text { General Health } \\
\text { (2) }\end{array}$ & $\begin{array}{c}\text { All } \\
\text { Characteristics } \\
\text { (3) }\end{array}$ \\
\hline \multicolumn{4}{|l|}{ Disability Type (Ref: No Disability): } \\
\hline \multirow[t]{2}{*}{ Blindness or a serious vision impairment } & $-0.038 * * *$ & $-0.032 * * *$ & $-0.024 * * *$ \\
\hline & $(0.008)$ & $(0.007)$ & $(0.007)$ \\
\hline \multirow[t]{2}{*}{ Deafness or a serious hearing impairment } & $-0.036 * * *$ & $-0.030 * * *$ & $-0.015 * * *$ \\
\hline & $(0.005)$ & $(0.005)$ & $(0.004)$ \\
\hline \multirow[t]{2}{*}{$\begin{array}{l}\text { Difficulty with basic physical activities such as } \\
\text { walking, climbing stairs, reaching, lifting or carrying }\end{array}$} & $-0.147^{* * *}$ & $-0.094 * * *$ & $-0.070 * * *$ \\
\hline & $(0.007)$ & $(0.006)$ & $(0.005)$ \\
\hline \multirow[t]{2}{*}{ Intellectual Disability } & $-0.043 * * *$ & $-0.044 * * *$ & $-0.042 * * *$ \\
\hline & $(0.012)$ & $(0.012)$ & $(0.012)$ \\
\hline \multirow[t]{2}{*}{ Difficulty in learning, remembering or concentrating } & $-0.057^{* * *}$ & $-0.043^{* * *}$ & $-0.041 * * *$ \\
\hline & $(0.006)$ & $(0.006)$ & $(0.006)$ \\
\hline \multirow[t]{2}{*}{ Psychological or emotional condition } & $-0.081 * * *$ & $-0.058 * * *$ & $-0.057 * * *$ \\
\hline & $(0.006)$ & $(0.006)$ & $(0.005)$ \\
\hline \multirow[t]{2}{*}{$\begin{array}{l}\text { Difficulty with pain, breathing or any other chronic } \\
\text { illness or condition }\end{array}$} & & $-0.005^{*}$ & $-0.005 * *$ \\
\hline & $(0.003)$ & $(0.003)$ & $(0.002)$ \\
\hline \multicolumn{4}{|l|}{ General Health (Ref: Very Good/Good): } \\
\hline \multirow[t]{2}{*}{ Fair } & & $-0.109 * * *$ & $-0.076 * * *$ \\
\hline & & $(0.003)$ & $(0.003)$ \\
\hline \multirow[t]{2}{*}{ Bad/Very Bad } & & $-0.156 * * *$ & $-0.121 * * *$ \\
\hline & & $(0.012)$ & $(0.011)$ \\
\hline \multicolumn{4}{|l|}{ Gender (Ref: Female): } \\
\hline \multirow[t]{2}{*}{ Male } & & & $-0.002 *$ \\
\hline & & & $(0.001)$ \\
\hline \multicolumn{4}{|l|}{ Age (Ref: Age 35-44): } \\
\hline \multirow[t]{2}{*}{$15-19$} & & & $-0.126 * * *$ \\
\hline & & & $(0.019)$ \\
\hline \multirow[t]{2}{*}{$20-24$} & & & $-0.014 * * *$ \\
\hline & & & $(0.005)$ \\
\hline \multirow[t]{2}{*}{$25-34$} & & & $0.007^{* * *}$ \\
\hline & & & $(0.002)$ \\
\hline \multirow[t]{2}{*}{$45-54$} & & & $-0.021 * * *$ \\
\hline & & & $(0.001)$ \\
\hline \multirow[t]{2}{*}{$55-64$} & & & $-0.087 * * *$ \\
\hline & & & $(0.002)$ \\
\hline \multicolumn{4}{|l|}{ Ethnicity (Ref: Other): } \\
\hline \multirow[t]{2}{*}{ White } & & & $0.028 * * *$ \\
\hline & & & $(0.003)$ \\
\hline
\end{tabular}


TABLE 5.29 CONTD.

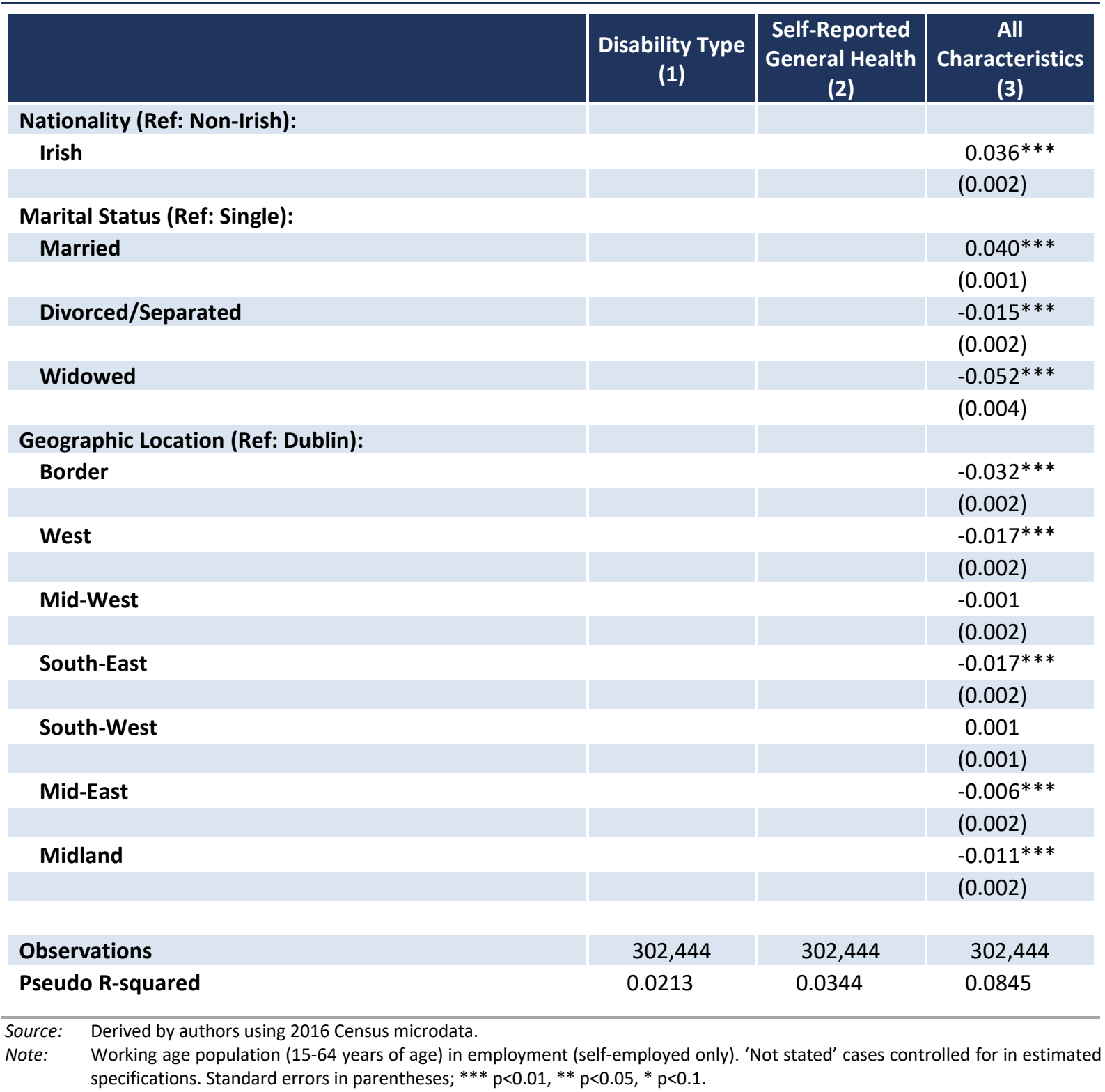


TABLE 5.30 IMPACT OF DISABILITY TYPE ON A PERSON'S PROBABILITY OF SELFEMPLOYMENT BY GENDER: 2016 (MARGINAL EFFECTS)

\begin{tabular}{|c|c|c|c|}
\hline & $\begin{array}{l}\text { All } \\
\text { (1) }\end{array}$ & $\begin{array}{l}\text { Males } \\
\text { (2) }\end{array}$ & $\begin{array}{c}\text { Females } \\
\text { (3) }\end{array}$ \\
\hline \multicolumn{4}{|l|}{ Disability Type (Ref: No Disability): } \\
\hline \multirow[t]{2}{*}{ Blindness or a serious vision impairment } & $-0.024 * * *$ & $-0.031 * * *$ & 0.004 \\
\hline & $(0.007)$ & $(0.008)$ & $(0.011)$ \\
\hline \multirow[t]{2}{*}{ Deafness or a serious hearing impairment } & $-0.015^{* * *}$ & $-0.015 * * *$ & $-0.018^{*}$ \\
\hline & $(0.004)$ & $(0.004)$ & $(0.010)$ \\
\hline \multirow[t]{2}{*}{$\begin{array}{l}\text { Difficulty with basic physical activities such as walking, } \\
\text { climbing stairs, reaching, lifting or carrying }\end{array}$} & $-0.070 * * *$ & $-0.078 * * *$ & $-0.043 * * *$ \\
\hline & $(0.005)$ & $(0.006)$ & $(0.009)$ \\
\hline \multirow[t]{2}{*}{ Intellectual Disability } & $-0.042 * * *$ & $-0.037 * * *$ & $-0.068 * *$ \\
\hline & $(0.012)$ & $(0.012)$ & $(0.034)$ \\
\hline \multirow[t]{2}{*}{ Difficulty in learning, remembering or concentrating } & $-0.041 * * *$ & $-0.040 * * *$ & $-0.040 * * *$ \\
\hline & $(0.006)$ & $(0.006)$ & $(0.013)$ \\
\hline \multirow[t]{2}{*}{ Psychological or emotional condition } & $-0.057 * * *$ & $-0.061 * * *$ & $-0.048 * * *$ \\
\hline & $(0.005)$ & $(0.007)$ & (0.009) \\
\hline \multirow[t]{2}{*}{$\begin{array}{l}\text { Difficulty with pain, breathing or any other chronic illness } \\
\text { or condition }\end{array}$} & $-0.005^{* *}$ & $-0.006 * *$ & -0.004 \\
\hline & $(0.002)$ & $(0.003)$ & $(0.005)$ \\
\hline $\begin{array}{l}\text { Derived by authors using } 2016 \text { Census microdata. } \\
\text { Working age population ( } 15-64 \text { years of age) in employment } \\
\text { nationality, marital status, geographic location, and not stated cas } \\
\text { parentheses; }{ }^{* * *} p<0.01,{ }^{* *} p<0.05,{ }^{*} p<0.1 \text {. }\end{array}$ & 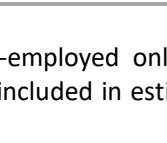 & . & $\begin{array}{l}\text { icity, } \\
\text { rrs in }\end{array}$ \\
\hline
\end{tabular}

\subsection{SUMMARY}

Based on the Census data, 11.5 per cent of the working age population reported having a disability in 2016, which was up slightly from 11 per cent in 2011. The main types of disability in both 2011 and 2016 were 'difficulty with basic physical activities such as walking, climbing stairs, reaching, lifting or carrying', a 'psychological or emotional condition' and 'difficulty in learning, remembering or concentrating'. In relation to everyday difficulties, 36 per cent of those that reported having a disability in 2016 indicated that they had difficulty undertaking work/study. This was followed by difficulty undertaking other activities (30.6 per cent), and difficulty going outside (18.7 per cent). Over a third of those people that reported having a disability in $\mathbf{2 0 1 6}$ had more than one disability.

In relation to educational attainment levels, a much lower percentage of those with disabilities had a third-level qualification in 2016. This percentage increased between 2011 and 2016, with the numbers with a primary or lower qualification decreasing. Part of the reason why those with disabilities have lower levels of educational attainment is due to their older age profile. Nevertheless, when we examined educational attainment levels by age cohort, we still found that a much smaller percentage of young people (aged 15 to 29) with disabilities had a thirdlevel qualification compared to those without, and the gap was similar to that among their older cohorts. 
There was substantial variation in educational attainment levels across disability type groups. For example, only 6 per cent of people that reported having an intellectual disability in $\mathbf{2 0 1 6}$ had a third-level qualification, which was much lower compared to those with a psychological or emotional condition (29.2 per cent), those with a hearing disability (28.6 per cent) and those that had blindness or a serious vision impairment (27.1 per cent).

Only a third of the working age people with disabilities indicated that their main economic status in 2016 was employment, which compares with two-thirds of those without. There was considerable variation in the percentages in employment by disability type. In particular, only 14.7 per cent of individuals with an intellectual disability were working in 2016. The same was true of those with 'difficulty with basic physical activities such as walking, climbing stairs, reaching, lifting or carrying' (18.1 per cent) and 'difficulty in learning, remembering or concentrating' (20.7 per cent). On the other hand, a larger proportion of those that reported having 'deafness or a serious hearing impairment' (45.7 per cent) or having 'blindness or a serious vision impairment' (34 per cent) were in employment in 2016.

We found that there was not much variation in the occupational distribution among those of working age with and without disabilities in 2016, nor was there a substantial change in this distribution between 2011 and 2016. There was, however, variation by disability type. For example, those with an intellectual disability were less likely to be managers, directors, or senior officials, or in professional occupations or associate professional and technical occupations in 2016. On the other hand, those that had deafness or a serious hearing impairment, or had blindness or a serious vision impairment were more likely to be in these positions.

We found that having a disability had a negative impact on an individual's likelihood of being in employment in both 2011 and 2016, with the negative effect being greater for being an employee than self-employed. In both instances, the negative effect was slightly larger for males.

The impact of having a disability on a person's employment chances was found to vary by disability type. Specifically, those with a psychological or emotional condition or difficulties with basic physical activities such as walking, climbing stairs, reaching, lifting or carrying were most severely impacted, in terms of either being an employee or self-employed. For all disability types, the negative effect was slightly larger among males. 



\section{CHAPTER 6}

\section{European Union Statistics on Income and Living Conditions (EU-SILC): 2018}

\section{$6.1 \quad$ INTRODUCTION}

In Chapter 3, we used the Irish SILC data to explore the relationship between disability and employment characteristics for the period 2004 to 2019. These data are a component of a European wide survey called the European Union Statistics on Income and living Conditions (EU-SILC). In this chapter we use the 2018 EU-SILC to compare the prevalence and severity of disability in Ireland with 27 other EU Member States. As mentioned in Chapter 2, the measure of disability in the EU-SILC is identical to the one in the Irish SILC data. Given, as was discussed in Chapter 2, that the SILC disability measure is subjective, the variation in the prevalence and the severity of disability across countries that is presented in this chapter could be sensitive to sociological and cultural difference across countries.

In this chapter, like in Chapter 3, we focus on the population aged 16 to 64 . We also, where the data permits, adopt a similar analysis structure to that used in Chapters 3 and 5. Specifically, we compare those aged 16-64 with and without disabilities across a range of demographic characteristics (e.g. age, gender, and education). We then explore differences in the labour market characteristics of both populations, along with how labour market outcomes vary by the severity of disability. Finally, we look at poverty exposure for people with disabilities and the role of employment status as a protective factor against poverty.

\subsection{SOCIO-DEMOGRAPHIC CHARACTERISTICS}

Figure 6.1 shows that the range of prevalence of disability across the EU28 is extremely wide. ${ }^{42}$ It goes from a low of 8 per cent in Malta to a high of 30 per cent in Estonia. At 12 per cent, Ireland has the fifth lowest prevalence of disability. While there is no clear pattern, we find the lowest levels of disabilities among a mix of Southern and Eastern European countries, while Northern European countries (except Sweden) tend to report the highest levels of disability.

Overall, only a small proportion of people have strong limitations in their daily activities ( 5 per cent). For almost half of the countries, less than 5 per cent of people have strongly limited activities: it is 3 per cent in Ireland, while for the other countries it does not reach 10 per cent. At 9 per cent, the UK has the highest value. 
It would be beyond the scope of this project to attempt to explain the level of prevalence of disabilities for each country or even by groups of countries such as a welfare regime typology (Esping-Andersen, 1999). However, we can make a few hypotheses. First it is important to highlight that the measure of disability is a subjective measure and is self-defined. As such, variation across countries could be explained by cultural differences in people's propensity to report health issues. For example, using the same SILC data, people in Ireland were found to report high levels of self-reported good health (Delaney et al., 2007; OECD/EU, 2018; Watson et al., 2015). Second, regarding the higher level of disabilities in Nordic countries, it is likely that in these countries the social health services are better resourced and more proactive in detecting disabilities and people might be more likely to report any disabilities. Another explanation based on the literature as suggested by Bratsberg et al. (2010) is that in some countries there is a 'certain degree of substitution between unemployment and disability insurance program utilization'. Indeed, Bratsberg et al. (2010) note that Nordic countries are characterised by low level of unemployment and speculated that this could explain their higher level of disabilities. Focusing on Norway, Bratsberg et al. (2010) found an association between an increase in the number of people with disabilities and a reduction in employment opportunities, and Rege et al. (2005) found also an association with plant downsizing.

On the other hand, the proportion of people reporting limited activities is much higher. This ranges from 6 per cent in Malta and Greece to a high of 24 per cent in Latvia. It is 8 per cent in Ireland. Overall, we note that there is some degree of association between the prevalence of people reporting 'strongly limited' and 'limited' activities (correlation of 0.5 ).

\section{FIGURE 6.1 PREVALENCE AND DEGREE OF DISABILITY ACROSS EU28: 2018 (\%)}

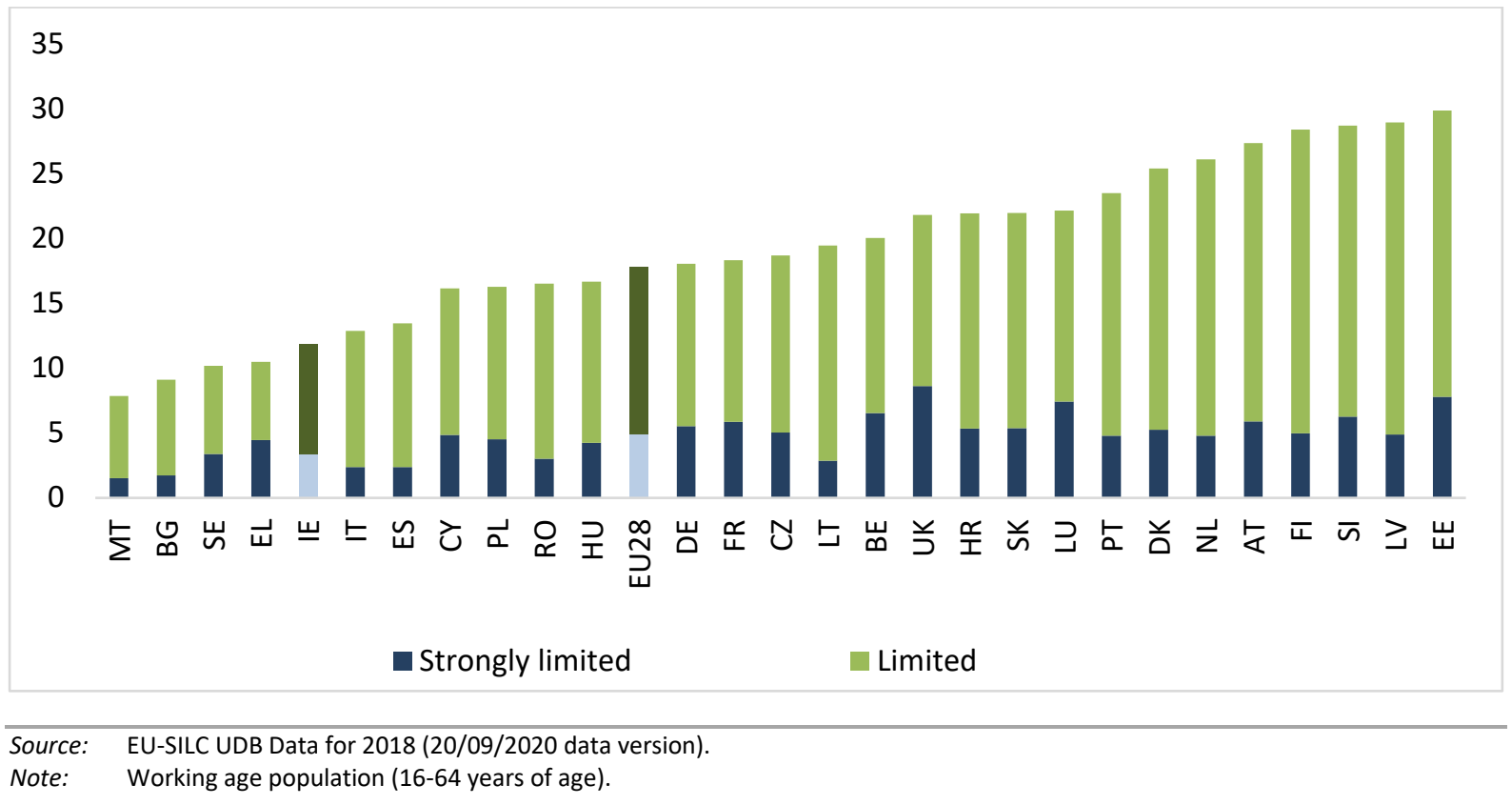


In the vast majority of countries, the prevalence of disability for men and women is quite similar (Figure 6.2), and when differences occur it is higher among women. Across the EU28, the prevalence of disability is 17 per cent for men and 19 per cent for women, and it is respectively 11 per cent and 12 per cent in Ireland. However, in a few countries the gender gap can be quite large, particularly in the Nordic countries. It is 5 percentage points higher for women in Sweden, 7 percentage points in the Netherlands and Finland, and 8 percentage points in Denmark. With the exception of Portugal, Southern European countries tend to have very low gender gaps, ranging between 1 and 2 percentage points in Cyprus, Malta, Greece, Italy, and Spain.

\section{FIGURE 6.2 PREVALENCE OF DISABILITY BY GENDER ACROSS EU28: 2018 (\%)}

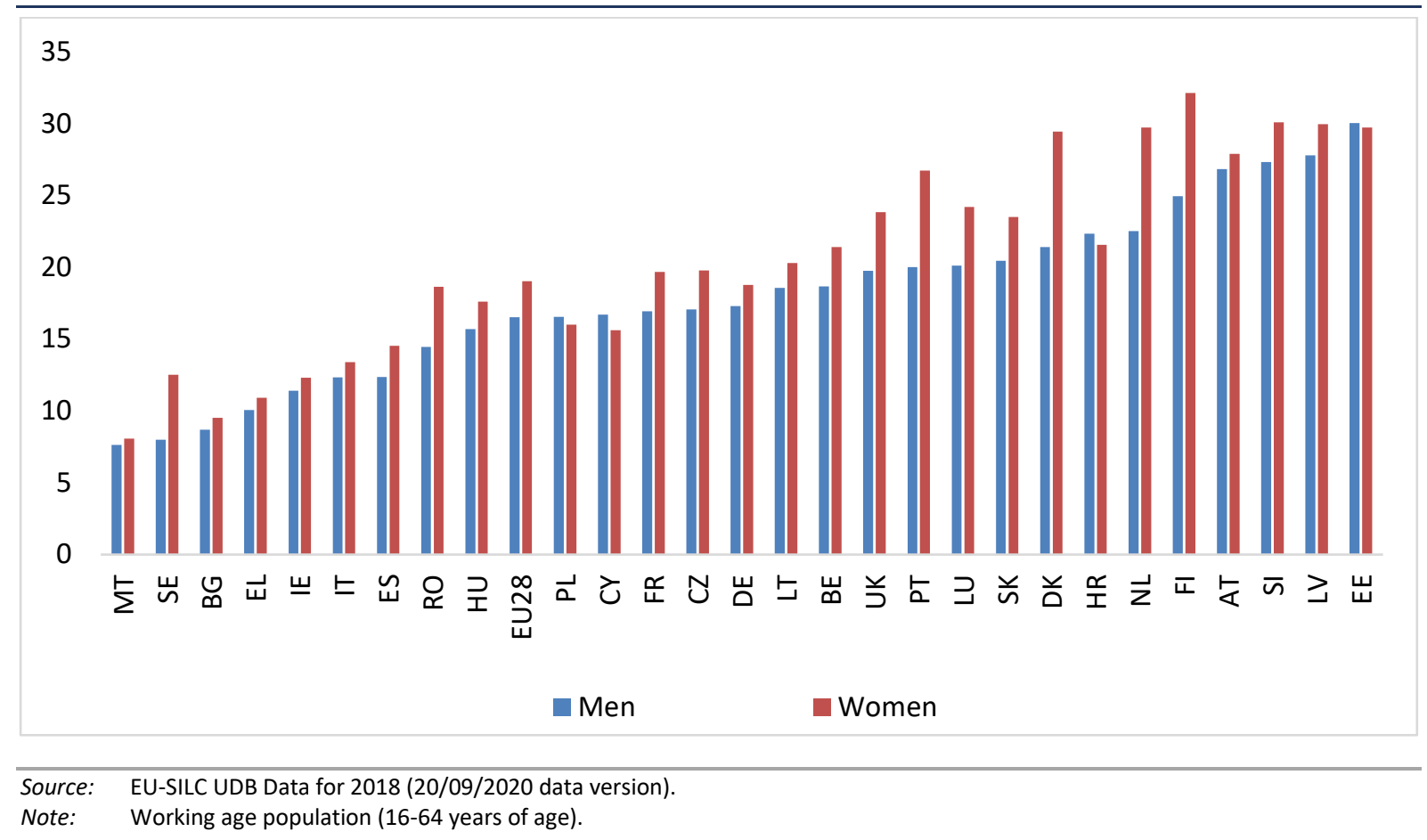

In Figure 6.3 we present the age distribution of people with disabilities: countries are sorted by ascending order of the older age group, as it is the largest age group for people with disabilities across all countries. Not surprisingly, the age composition of people with disabilities increases with age. Looking at the youngest age group first, there is a large variation across countries, ranging from a low of 11 per cent in Greece and the Czech Republic to a high of 27 per cent in Finland. It is respectively 19 per cent and 20 per cent in Ireland and the EU28. Overall, Nordic countries tend to have a higher proportion of young people with disabilities (over 24 per cent), while a few Southern European countries, such as Italy, Spain, and Greece, report the lowest proportions (11 to 13 per cent).

There is less variation across countries for the 35 to 44 age group: it varies from 13 per cent in Germany, Lithuania, and Bulgaria to the highest value of 22 per cent in Spain. At 17 per cent, Ireland is in the middle of the EU28 country distribution. The proportion of older people with disabilities increases quite substantially as we 
move to the age group of 45 to 54 , and the variation across countries narrows again for this age group. Over a quarter of people with disabilities in the EU28 are in this age group, and, at 31 per cent, it is slightly higher in Ireland.

Finally, the proportion of people with disabilities increases further for the 55 to 64 age group, as does the variation across countries. The proportion of people with disabilities aged 55 to 64 is lowest in the Northern European countries, ranging between 28 and 32 per cent ( 32 per cent in Ireland), while it is between 40 per cent and 50 per cent for ten other, mostly Eastern European, countries.

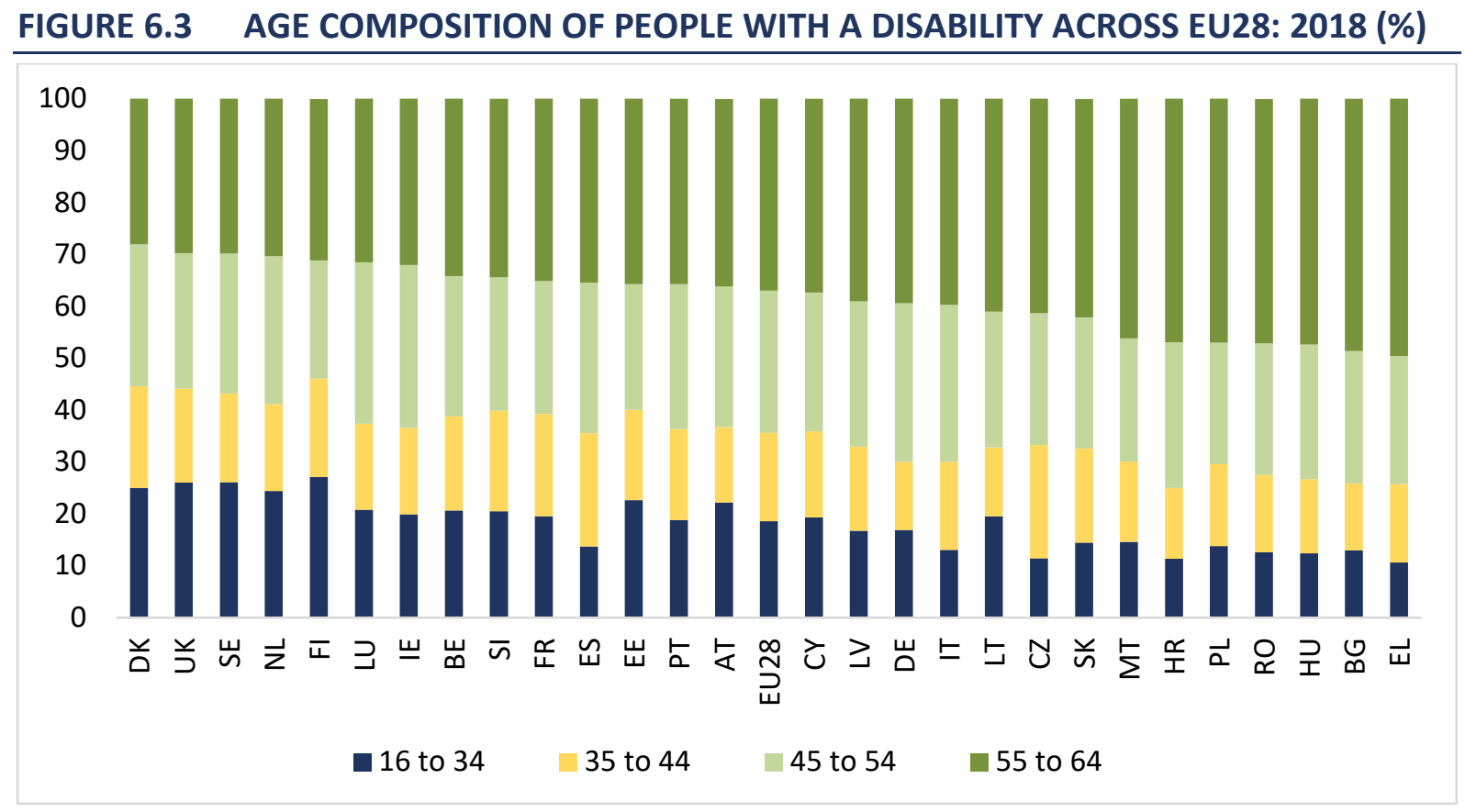

Source: EU-SILC UDB Data for 2018 (20/09/2020 data version).

Note: Working age population (16-64 years of age).

However, as disability increases with age, the age composition of people with disabilities will depend also on the age structure of the population studied. Therefore, in order to have a meaningful understanding of Figure 6.3, we report in Table 6.1 the ratio of the percentages presented in Figure 6.3 to the percentage of the age structure of the population aged 16 to 64 . A ratio equal to 1 means that there is a perfect representation of the population with disabilities to the corresponding total population. A ratio below 1 means that there is an under-representation of people with disabilities, while a ratio above 1 means that there is an over-representation of people with disabilities.

Across all countries, while the ratio increases between the age of 16-34 and 35-44, there is an under-representation of people with disabilities under the age of 45 (with the exception of France where the ratio is 1 for the age group 35-44). Among the age group 45-54, there is a slight over-representation of people with disabilities across all countries. With a ratio of 1.3 , Ireland is among the many countries with the highest ratios. The over-representation increases quite substantially among 
the older age group 55-64, and there is quite a lot of variation across countries as it goes from a low 1.5 in Denmark, Finland, the Netherlands and the UK to a high of 2.3 and 2.4 in Bulgaria, Greece and Romania. While there is no clear pattern across countries, it seems however that there is a higher over-representation of older people with disabilities in Eastern European countries, with many of these countries having more than twice the overall representation of people aged 55 to 64. At 1.7, it is much lower in Ireland, a similar level to the EU28.

TABLE 6.1 RATIO OF REPRESENTATION OF PEOPLE WITH DISABILITIES BY AGE GROUP: 2018

\begin{tabular}{|c|c|c|c|c|}
\hline & 16 to 34 & 35 to 44 & 45 to 54 & 55 to 64 \\
\hline AT & 0.6 & 0.7 & 1.2 & 1.7 \\
\hline BE & 0.6 & 0.9 & 1.2 & 1.7 \\
\hline BG & 0.4 & 0.6 & 1.2 & 2.3 \\
\hline CY & 0.4 & 0.8 & 1.4 & 2.2 \\
\hline$C Z$ & 0.3 & 0.8 & 1.2 & 2.1 \\
\hline DE & 0.5 & 0.7 & 1.2 & 1.7 \\
\hline DK & 0.7 & 0.9 & 1.2 & 1.5 \\
\hline EE & 0.6 & 0.8 & 1.2 & 1.7 \\
\hline EL & 0.3 & 0.6 & 1.0 & 2.3 \\
\hline ES & 0.4 & 0.9 & 1.2 & 1.8 \\
\hline FI & 0.7 & 0.9 & 1.1 & 1.5 \\
\hline FR & 0.5 & 1.0 & 1.3 & 1.6 \\
\hline HR & 0.3 & 0.6 & 1.3 & 2.1 \\
\hline HU & 0.4 & 0.7 & 1.1 & 2.0 \\
\hline IE & 0.5 & 0.8 & 1.3 & 1.7 \\
\hline IT & 0.4 & 0.8 & 1.2 & 1.9 \\
\hline LT & 0.5 & 0.7 & 1.2 & 1.9 \\
\hline LU & 0.6 & 0.8 & 1.3 & 1.6 \\
\hline LV & 0.5 & 0.8 & 1.3 & 1.8 \\
\hline MT & 0.4 & 0.7 & 1.3 & 2.2 \\
\hline NL & 0.7 & 0.9 & 1.2 & 1.5 \\
\hline PL & 0.4 & 0.7 & 1.3 & 2.2 \\
\hline PT & 0.6 & 0.8 & 1.2 & 1.7 \\
\hline RO & 0.4 & 0.6 & 1.1 & 2.4 \\
\hline SE & 0.7 & 0.8 & 1.2 & 1.6 \\
\hline SI & 0.6 & 0.9 & 1.2 & 1.7 \\
\hline SK & 0.4 & 0.7 & 1.3 & 2.1 \\
\hline UK & 0.7 & 0.8 & 1.2 & 1.5 \\
\hline EU28 & 0.5 & 0.8 & 1.2 & 1.7 \\
\hline
\end{tabular}

Source: EU-SILC UDB Data for 2018 (20/09/2020 data version).

Note: Working age population (16-64 years of age).

Education level is a strong predictor of employment (OECD, 2015). Specifically, people with higher qualifications and education levels have high employment rates (OECD, 2015). We report in Figure 6.4 the education level of people by disability status. Countries have been sorted by ascending order of third-level education for people without disabilities. 
In the top panel we can see that in most countries much less than 10 per cent of people without disabilities aged 16 to 64 have primary or lower education level. The exception is Portugal where this figure reaches a high of 23 per cent. At 4 per cent, it is very low in Ireland, and also in the EU28 as a whole. The corresponding figures for people with disabilities (bottom panel) shows a higher proportion with lower levels of education. However, it still remains relatively low for most of the countries, with the exception of a few. At 43 per cent, Portugal has the highest percentage of low education levels among people with disabilities, followed by Greece at 29 per cent. Five countries then have values of between 15 per cent and 29 per cent. This includes Ireland (15 per cent), while the EU28 average is 10 per cent.

Looking at the secondary level of education for people without disabilities, it ranges from 39 per cent in Ireland to a high of 78 per cent in Croatia. The EU28 average is 60 per cent. Once more, there is a much higher proportion of people with secondary level of education among people with disabilities than among those without. There are, however, a few exceptions as it is the opposite in Italy, Portugal and Greece. In Ireland, 43 per cent of people with disabilities have a second-level qualification. It is 65 per cent for the EU28 as a whole.

Across all countries, the percentage of people without disabilities with postsecondary level education is higher than among people with disabilities. For people without disabilities, it ranges from 20 per cent in Italy to 58 per cent in Lithuania. Ireland has the second highest value at 57 per cent. The corresponding figures for people with disabilities goes from 11 per cent in Croatia to 50 per cent in Lithuania. At 42 per cent, Ireland has the second highest value.

Looking at the education gap for post-secondary level education between people without disabilities and those with disabilities, the gap is very large in Sweden (18 percentage points difference) and Ireland (15 percentage points difference). The lowest gap is in Italy, mainly because the proportion of people with a postsecondary level education among those without disabilities is relatively low. The education gap is also low in Denmark and Finland, as well as among the Baltic countries. Across the EU28 as a whole, the education gap is 11 percentage points. However, regardless of disability status, the proportion of people with a postsecondary level education in Ireland is high. 

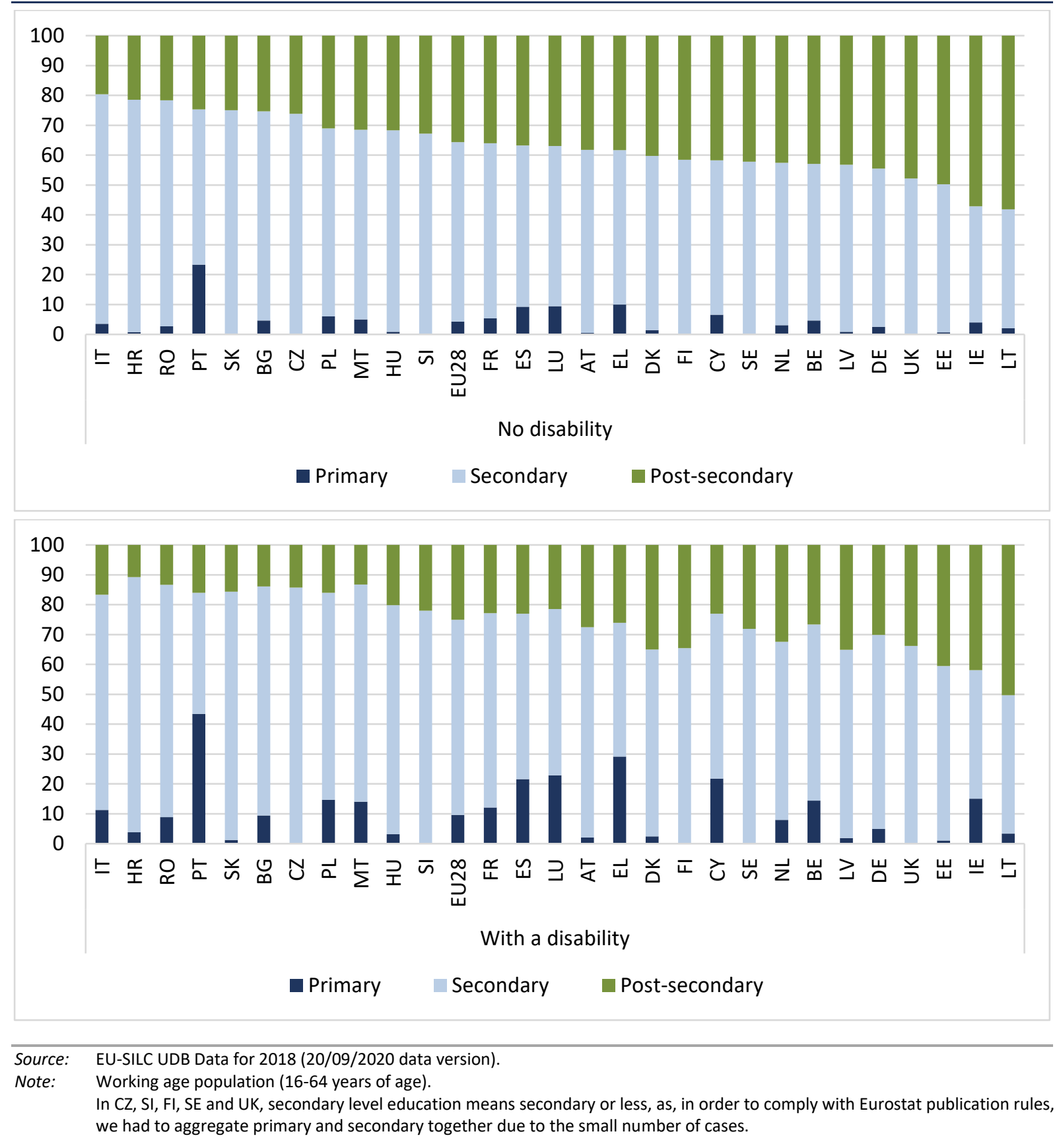

\subsection{EMPLOYMENT CHARACTERISTICS}

There is strong evidence that people's health status impacts their ability to participate in the labour market (Cai and Kalb, 2006). In Figure 6.5 we report the proportion of people aged 16 to 64 that are working by disability status across the EU28. Countries are ranked by ascending order of the employment rate of working people with disabilities. Not surprisingly, there is a much greater proportion of working people without disabilities than working people with disabilities. There is also much less variation across countries in the percentage of working people without disabilities than for working people with disabilities. For the former, it varies only from 57 per cent in Greece to 81 per cent in Estonia and the UK, while for the latter it ranges from 30 per cent in Greece to a high of 63 per cent in Estonia. In Ireland, the proportion of working people without disabilities is almost identical 
to the EU28 average: 71 per cent and 72 per cent respectively. At 36 per cent, Ireland has the fourth lowest percentage of working people with disabilities. As a consequence, Ireland has the second largest working gap after Bulgaria. At both ends of the spectrum, Greece has the lowest percentage of people at work regardless of a disability while Estonia has the highest percentage regardless of disability.

\section{FIGURE 6.5 EMPLOYMENT RATE BY DISABILITY STATUS ACROSS EU28: 2018 (\%)}

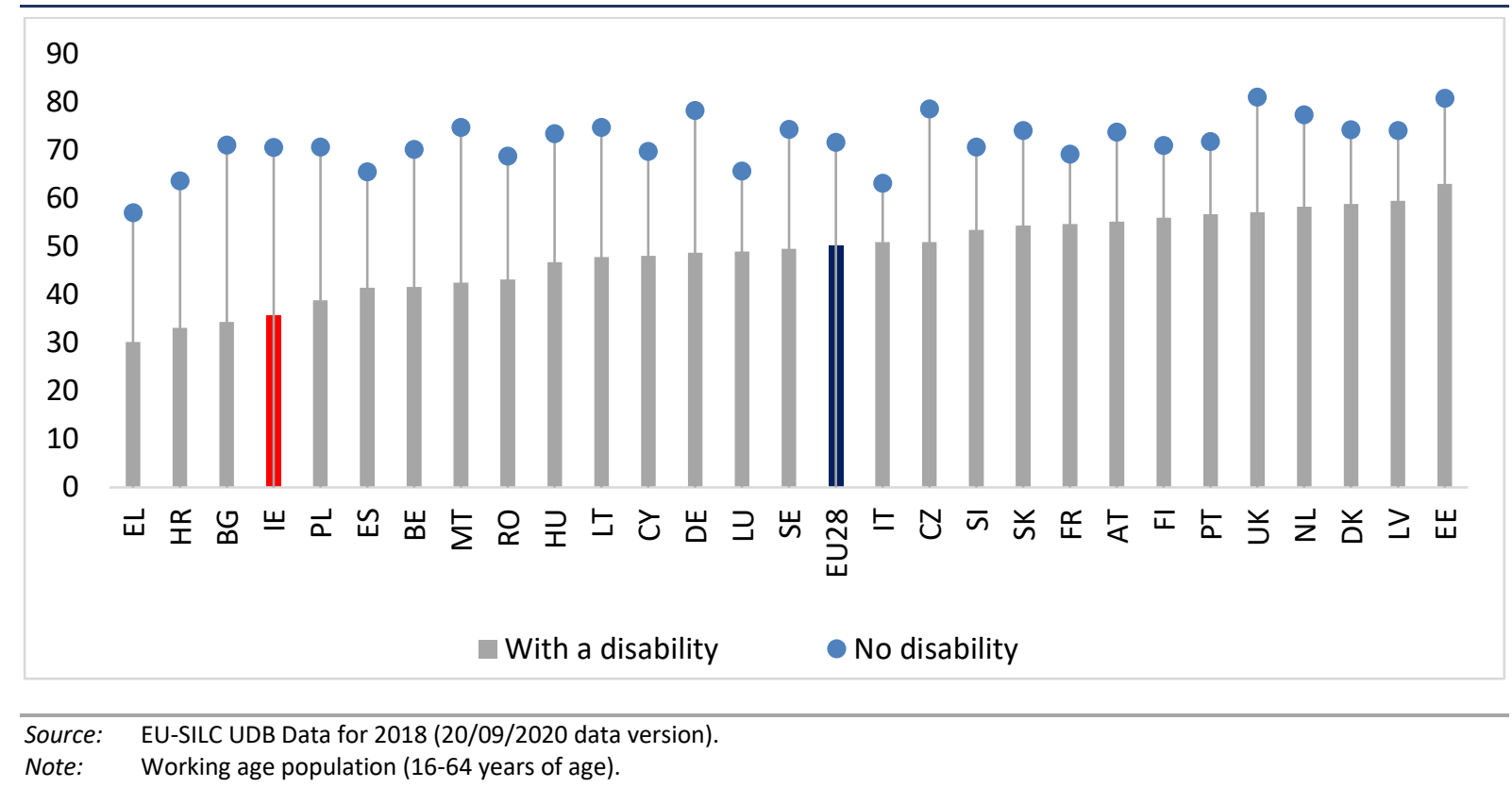

In Figure 6.6, we report the percentage of working people with disabilities by level of difficulty. Not surprisingly, across all countries the proportion of working people with strong limitations is much lower than those with less limitations. However, there is a large variation across countries in the working gap between levels of difficulty. Moreover, the range of variation is also much larger for people with strong limitations than among those with limitations 'only'. For the former, it goes from a low of 12 per cent in Romania to a high of 42 per cent in Estonia. At 28 per cent, Ireland is located in the middle of the distribution. For the latter, it ranges from 36 per cent in Greece to 73 per cent in the UK. In Ireland, the difference in the proportion of working people by limitations is quite modest as Ireland has the second lowest proportion of working people with limited activities (39 per cent). 


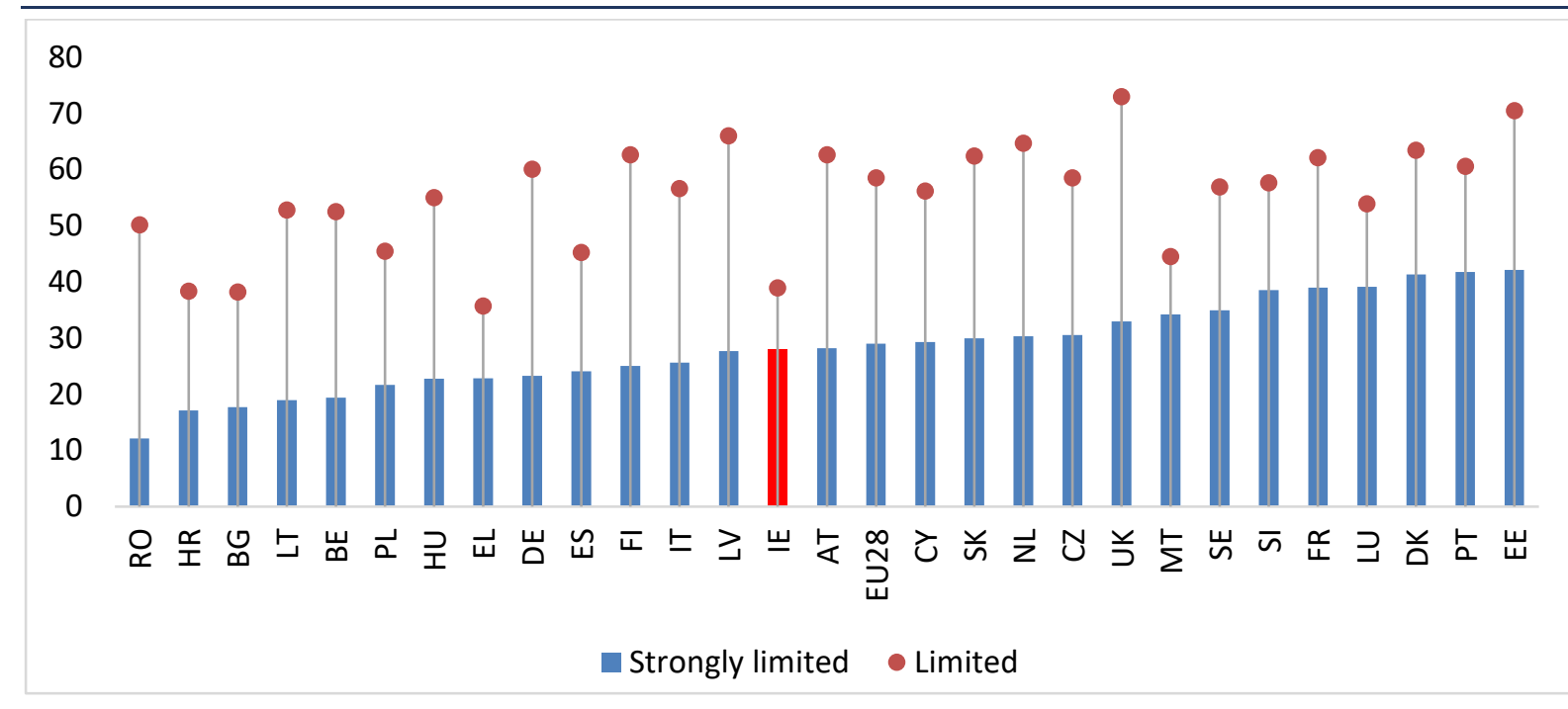

Source: EU-SILC UDB Data for 2018 (20/09/2020 data version).

Note: Working age population (16-64 years of age).

There is an extensive literature showing that people with disabilities are more likely to work part-time (Australian Bureau of Statistics, 2016; Eurostat, 2017), regardless of people's willingness to work part-time or full-time. We report in Figure 6.7 the proportion of people at work that are working full-time or part-time by disability status. ${ }^{43}$ Countries have been sorted by the ascending order of the proportion of people with disabilities that are working full-time.

In the top panel, across the EU28 countries, 83 per cent of people with no disability are working full-time: at 77 per cent, it is slightly lower in Ireland. The Netherlands has the lowest value at 59 per cent. This is partly due to the fact that a majority of women in the Netherlands work part-time (OECD, 2019). Overall, with a few exceptions, part-time work among people without disabilities in the EU15 countries is more common than among the most recently joined EU Member States.

The bottom panel shows that there is much more variation across countries in the proportion of people with disabilities working full-time than for their counterparts with no disability. Across the EU28, 74 per cent of working people with disabilities are working full-time, while, as indicated above, it is 83 per cent for those without disabilities. Ireland has the fifth lowest proportion at 66 per cent. In the Netherlands, less than half of working people with disabilities are working full-time (45 per cent).

43 The classification into full-time or part-time is self-defined by the respondent as there are variations in the weekly working hours across the EU as well as across industries. However, usually full-time would be defined as at least 30 hours per week. 
Interestingly, in the countries with the highest proportion of workers without disabilities working full-time, there is very little difference in the proportion of people with disabilities working full-time. Indeed, in the ten countries with the highest proportion of people with disabilities working full-time, the percentages range from 89 to 94 per cent, while it is from 93 to 98 per cent for their counterparts without disabilities. Most of these countries are Eastern European countries. It is important to highlight, though, that in many of these countries a smaller proportion of people with disabilities are at work (Croatia, Bulgaria). So, it is possible that in these countries there is a selection effect where working people with disabilities are more likely to work full-time as they have less severe disability. At the opposite end, some countries combine a high proportion of working people with disabilities with a high proportion of them working full-time (Latvia, Denmark, Estonia, Portugal, Slovenia).

\section{FIGURE 6.7 FULL-TIME VS PART-TIME EMPLOYMENT BY DISABILITY STATUS ACROSS} EU28: 2018 (\%)

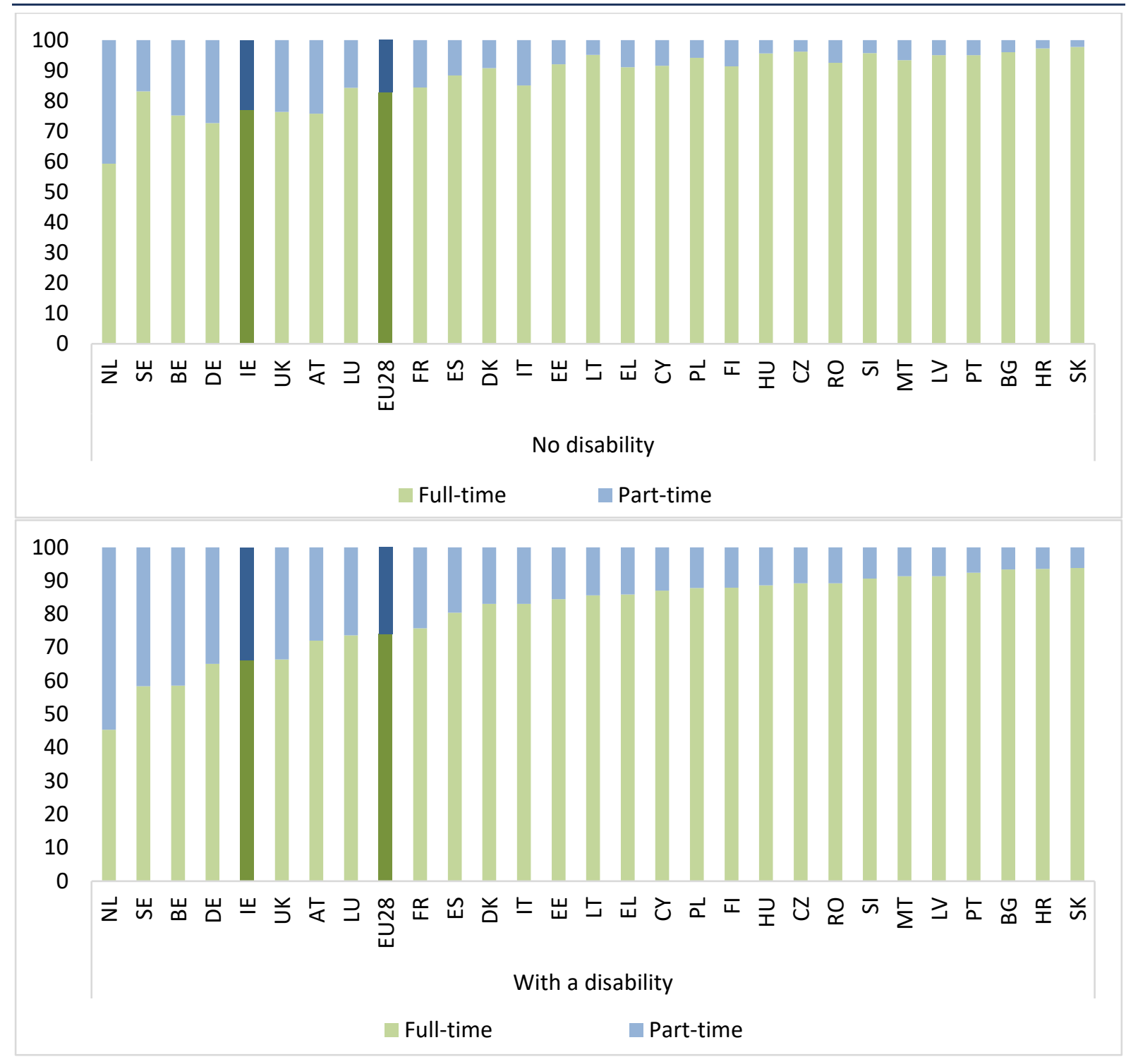

Source: EU-SILC UDB Data for 2018 (20/09/2020 data version).

Note: $\quad$ Working age population (16-64 years of age). 
Figure 6.6 showed that the severity of disability impacts on the working status of people with disabilities, and Figure 6.7 showed that people with disabilities are also less likely to work full-time than people without disabilities. We now explore in Figure 6.8 the relationship between severity of disability and full-time employment. Countries in Figure 6.8 have been sorted by ascending order of strong limitations.

As expected, people with strong limitations are less likely to work full-time than those with less limitations, but, quite surprisingly, the difference between limitations is very small and consistent across countries. There is no difference in the countries with the highest percentages of full-time workers with strong limitations (Bulgaria, Portugal, Romania, Croatia). The gap is also quite small in Ireland, as it is for the EU28 as a whole (8 percentage points).

FIGURE 6.8 FULL-TIME EMPLOYMENT BY SEVERITY OF DISABILITY ACROSS EU28: 2018 (\%)

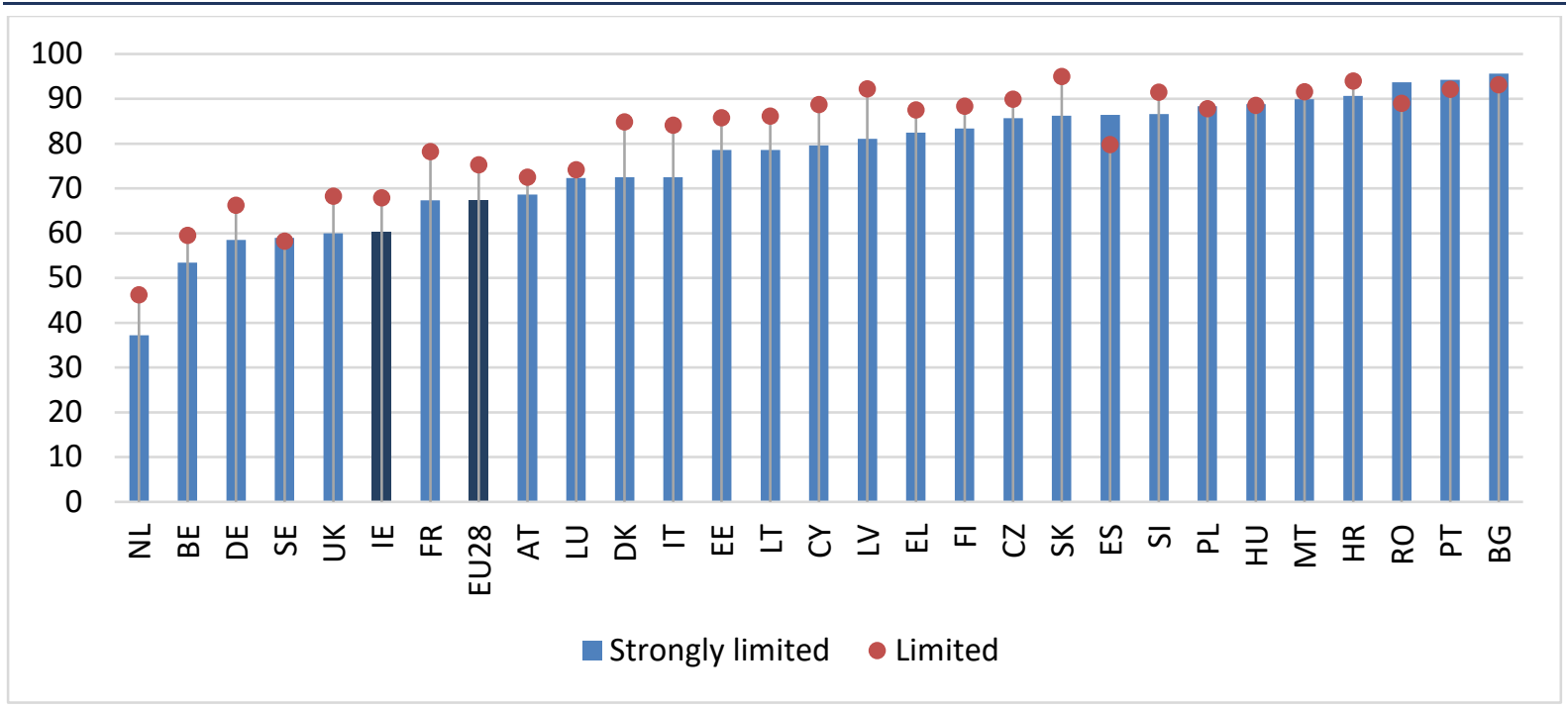

Source: EU-SILC UDB Data for 2018 (20/09/2020 data version).

Note: $\quad$ Working age population ( $16-64$ years of age).

For Bulgaria and Latvia, the figures have to be used with caution as there are between 20 and 49 observations.

In Figure 6.9 we explore the variation that exists across countries in the proportion of people in a managerial position by disability status. Regardless of disability status, there are large differences across countries in the percentage in a managerial position: it goes from 8 per cent in Romania to $43-44$ per cent in Austria. At 33 per cent, Ireland has the third highest proportion of people with disabilities in a managerial position.

In most of the countries, there is a greater proportion of people in managerial positions among those without disabilities than with disabilities. However, the differences are not large within countries. In Greece and Ireland, the proportion is even slightly greater among workers with disabilities. Compared to people with disabilities, the proportion of people without disabilities in a managerial position 
is larger in only six countries: it varies between 5 and 8 percentage points, and the

largest gap is in Sweden, Denmark and the Netherlands.

FIGURE 6.9 MANAGERIAL POSITION FOR WORKING PEOPLE BY DISABILITY ACROSS EU28: $2018(\%)$

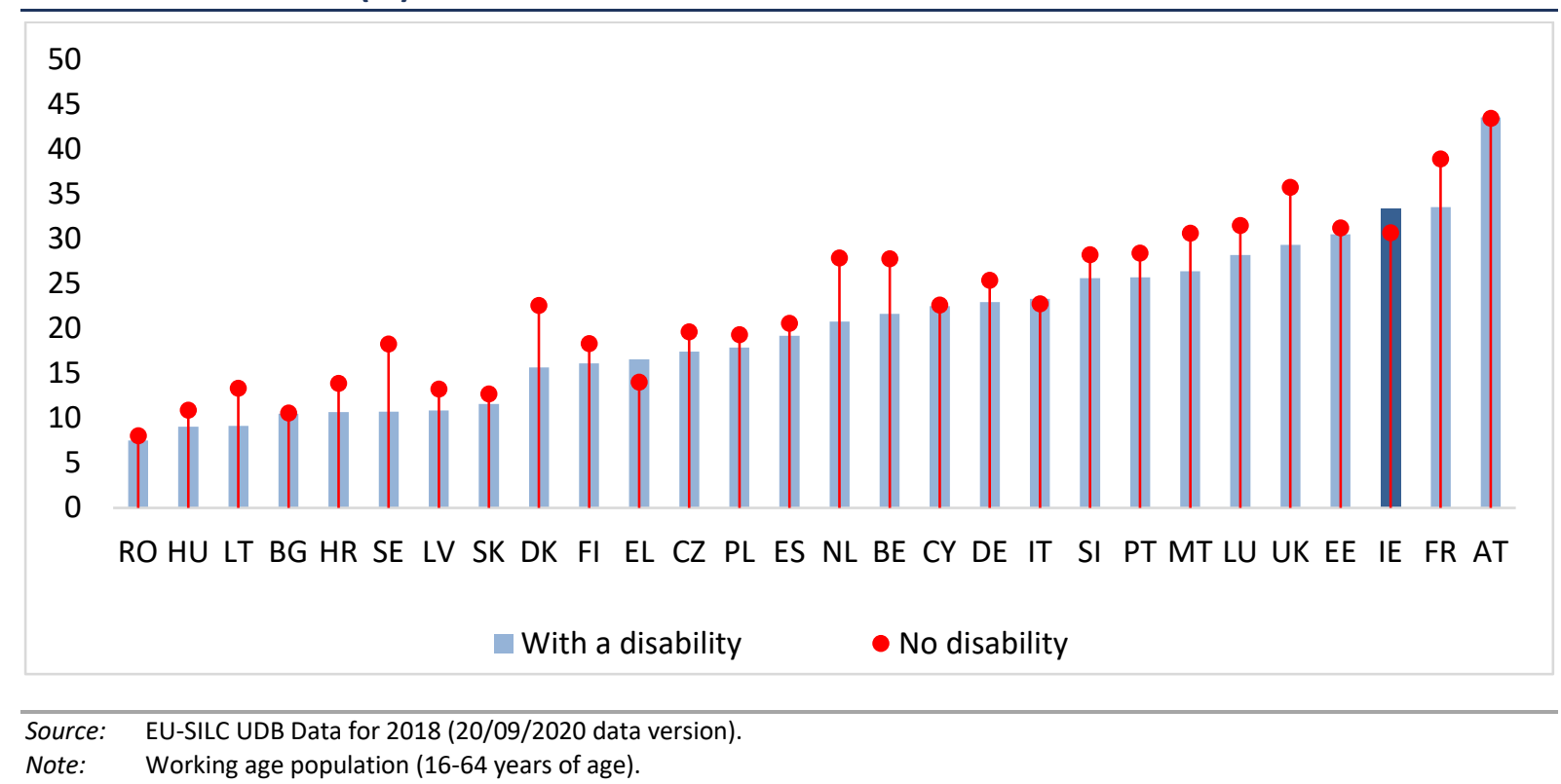

Every year, the EU-SILC survey includes an ad hoc module that collects information on a special topic. In 2018 the module was on material deprivation, well-being and housing difficulties. Among the set of questions on well-being and life satisfaction there was a question that asked about people's job satisfaction. People were asked to give a score varying from 0 (not at all satisfied) to 10 (completely satisfied). We report in Figure 6.10 the mean score on job satisfaction: the countries have been sorted by ascending order of the mean score for people with disabilities. ${ }^{44}$

All countries, regardless of disability status, have a mean score above the mid-value (5); and the variation is quite narrow for people with disabilities as it goes from a low of 5.6 in Bulgaria to a high of 7.8 in Finland. With a value of 7.8, people with disabilities in Ireland are quite satisfied with their job, which is the second highest mean score. With the exception of Germany, Northern European countries tend to have a high mean score while a few Eastern European countries, along with a few Southern European countries (Greece, Portugal, Spain, Italy), report low mean scores. In all countries people without disabilities report a higher mean score than those with disabilities, but in the vast majority of countries the gap is quite small. In Ireland, the gap is very small (7.8 vs 7.5). The largest gaps are in Lithuania, Germany, Slovenia, and Denmark. 
FIGURE 6.10 JOB SATISFACTION FOR WORKING PEOPLE BY DISABILITY ACROSS EU28: $2018(\%)$

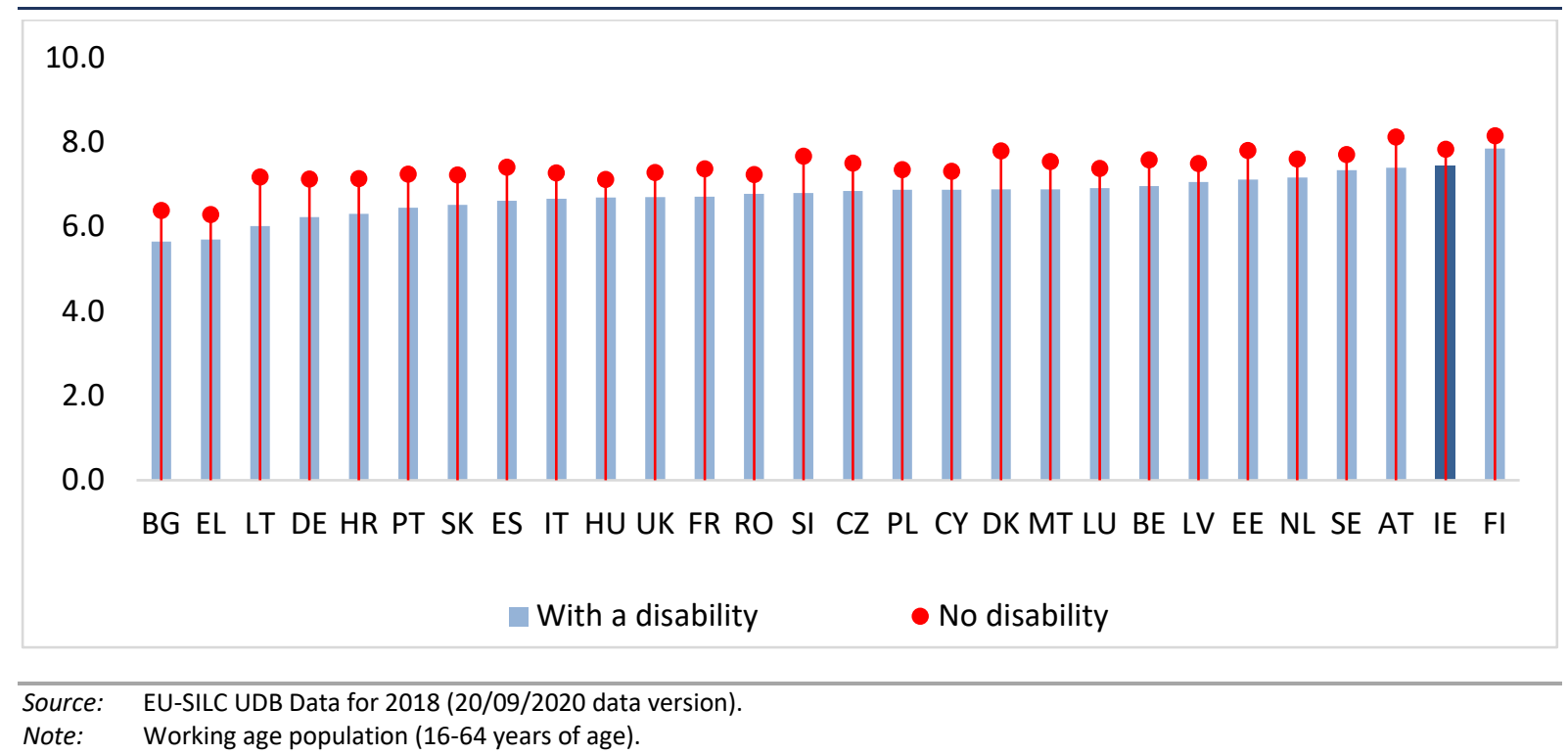

\subsection{DISABILITY AND POVERTY}

The literature on poverty shows that one of the most protective factors against poverty and social exclusion is being at work (OECD, 2009; Watson et al., 2012). The previous sections have highlighted the unequal employment characteristics by disability status, so we consider how this might impact on people's exposure to poverty in this section.

In Figure 6.11 we report the at risk of poverty (AROP) measure, which captures the percentage of people living in a households below 60 per cent of median equivalised household disposable income. ${ }^{45}$ The countries are sorted by the ascending order of the AROP measure of working people with disabilities.

Regardless of disability status, unemployed or inactive people have much higher AROP than working people. However, there are some large variations across countries by disability status and principal economic status. Data from 2018 ranges from 4 per cent in Finland to a high of 15 per cent in Romania, while it ranges for 5 per cent in Finland to 20 per cent in Romania for their disability counterparts. While Ireland is one of the countries with the lowest AROP for working people without disabilities ( 5 per cent), Ireland is in the middle of the distribution for the AROP for working people with disabilities (10 per cent). In 23 countries, the percentage point gap between the AROP of working people with and without disabilities is less than 5 per cent. However, Ireland has the fourth largest gap at almost 6 per cent. The largest gaps exist in Luxembourg, Hungary, and the UK.

45 Eurostat uses the 'Modified OECD' scale where the first adult (person aged 14 and over) gets a value of 1 , any additional adults a value of 0.5 and each child (aged less than 14) a value of 0.3 . The equivalised household income is the total disposable household income divided by the total number of 'equivalent adults'. 
Thus, while both populations of people with and without disabilities are working, the former are more exposed to poverty than the latter.

A comparison of the AROP of unemployed or inactive people with or without disability reveals much higher disparity between these groups than was the case for working people (Figure 6.11). First, the variation for unemployed or inactive people without disabilities is extremely large as it goes from a low of 18 per cent in the Czech Republic and Hungary to a high of 38 per cent in Sweden; it is 28 per cent in Ireland. The corresponding AROP for people with disabilities ranges from 22 per cent in Slovakia to 50 per cent in Estonia and Latvia, while it is 43 per cent in Ireland. Overall, the percentage gap for the AROP between unemployed or inactive people with disabilities and those without disabilities is much higher than for their working counterparts. Ireland has the fourth largest gap at 16 per cent, while the largest gap of 20 per cent is in Estonia. Once more, we find that for the same disadvantaged economic status of unemployment or inactivity, people with disabilities are much more exposed to poverty than people without disabilities.

FIGURE 6.11 AT RISK OF POVERTY BY WORK STATUS AND DISABILITY ACROSS EU28: $2018(\%)$

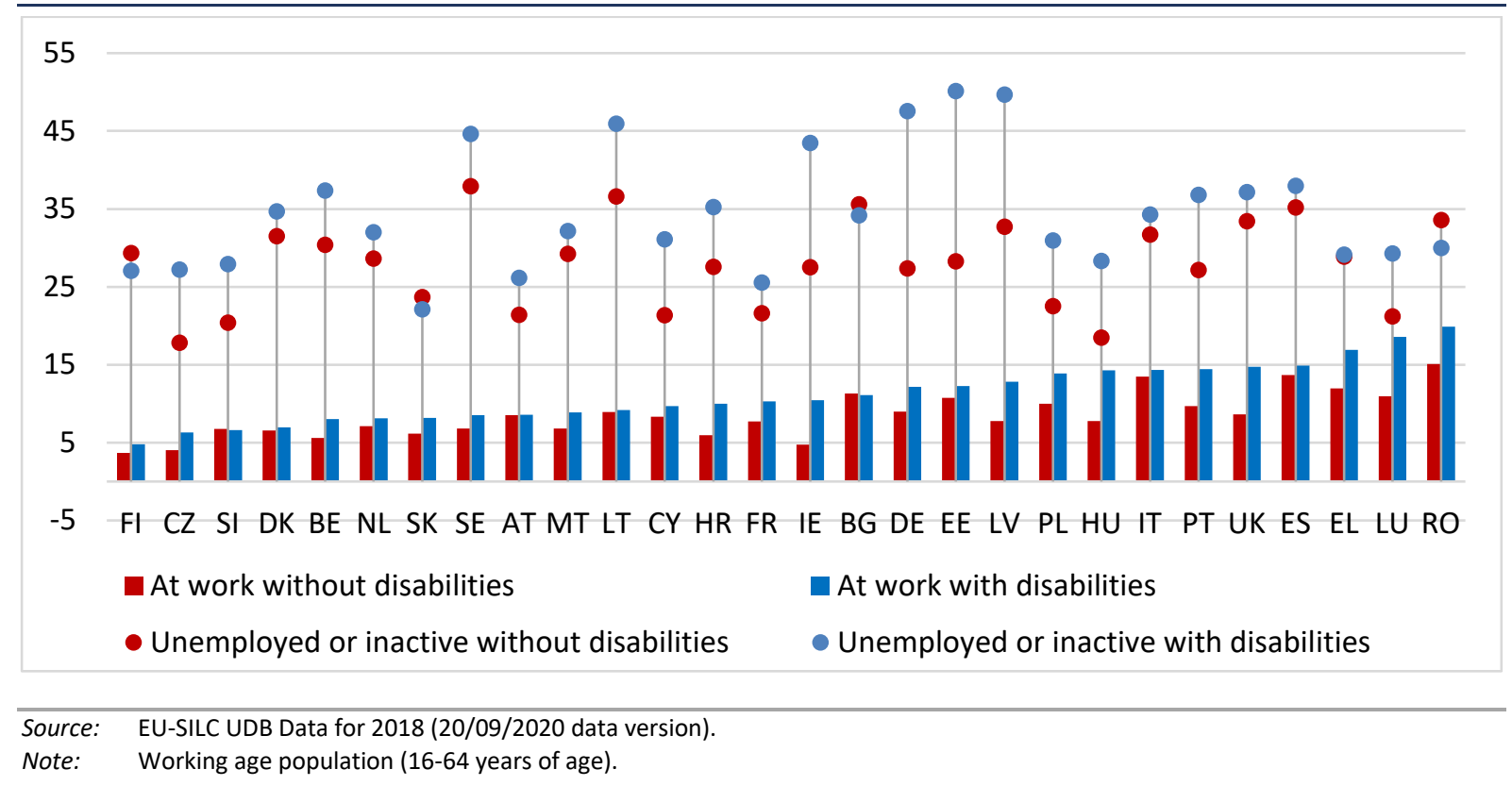

\subsection{SUMMARY}

The EU-SILC data examination provided a European comparison of people with disabilities in 2018. It was found that the prevalence of disability varies extensively across countries. At 12 per cent, Ireland had the fifth lowest prevalence of disability across the EU28 in 2018, while it was almost 30 per cent in Estonia.

A common feature across all European countries examined is a large proportion of people aged 55 to 64 among the working age population with disabilities. Nevertheless, there was still a large variation across countries in relation to this 
matter: Ireland had the seventh lowest proportion of this age group (32 per cent), while Greece had the highest value (52 per cent).

Another common feature across European countries is that there were relatively fewer people with disabilities with at least a post-secondary education level than among those without disabilities. However, Ireland was found to be again quite distinctive as it had the second highest proportion of people with disabilities with at least a post-secondary education (42 per cent), which was just after Lithuania (50 per cent). This percentage was found to be the lowest in Italy (17 per cent).

Ireland does not perform as well in relation to the working status of people with disabilities. Specifically, Ireland had the fourth lowest proportion of working people with disabilities (36 per cent), while it was the highest in Estonia (63 per cent). Ireland also had one of the largest working gaps between people without and with disabilities. Moreover, unlike most European countries, the severity of disability in Ireland is not strongly associated with working status. This suggests that in Ireland the barriers to work could be related to factors other than the severity of disability.

While Ireland was found not to be performing well in terms of work status of people with disabilities, it had the third highest proportion of people with disabilities in managerial position (33 per cent), just after Austria and France. This percentage was lowest in Romania (8 per cent).

In most European countries, working status was not found to protect people with disabilities from poverty to the same extent as those without, and the contrast can be quite sharp in some countries like Ireland. Indeed, Ireland had one of the lowest at risk of poverty rates for working people without disabilities, while, on average, it was much higher for people with disabilities. The poverty gap was even greater in Ireland, and is one of the largest across EU countries, when we compare people without disabilities and those with disabilities that are unemployed or inactive. 



\section{CHAPTER 7}

\section{Conclusions}

\section{$7.1 \quad$ INTRODUCTION}

The Comprehensive Employment Strategy 2015-2024 aims to support people with disabilities to access the labour market. The NDA identified data gaps particularly with regard to skill levels of persons with disabilities. As part of its 2013-2015 National Disability Strategy Implementation Plan, the government committed to publishing a comprehensive employment strategy (CES) for people with disabilities. This employment strategy was published in 2015 and aims to support people with disabilities to access the labour market.

Given this context, the NDA seeks insight into the workplace skills and capabilities of people with disabilities, including how this varies by disability type. In this report, we used a number of nationally representative data sources to examine the skills/ educational endowments and gaps among the working age population with disabilities compared to those without. Where feasible, we also differentiated those with disabilities by type and everyday difficulties. In addition, we examined the employment characteristics of people with disabilities, along with the impact of having a disability on a person's likelihood of being in employment. Finally, we use a comparative European dataset to compare the characteristics of people with and without disabilities in Ireland to their European counterparts.

\subsection{THE FINDINGS}

\subsubsection{Disabilities over time}

While using different datasets, years and measurement of disabilities, a common set of findings emerges from the study. Both SILC and Census of Population showed that, overall, the proportion of people with disabilities has been relatively stable over time. Within SILC, it went from 15 per cent in 2004 to 13 per cent in 2019, with very little difference by gender or by severity level.

While looking at a shorter time period, and using a different measure of disability, the proportion of people of working age with disabilities in the Census of Population was at 11 per cent and 11.5 per cent respectively in 2011 and 2016.

Using the EU-SILC 2018 data, it was found that the prevalence of disability among the working age population varied extensively across European countries. Ireland had the fifth lowest prevalence of disability (12 per cent) across the EU28 in 2018, while it was the highest in Estonia (30 per cent). It was outside of the scope of this project to explain cross-country differences in disability levels. Nevertheless, one 
possible reason for such variation may relate to the fact that in the data the measure of disability is a subjective measure and is self-defined. So, cross-country variation may be due to cultural differences in people's propensity to report health issues. Other possible reasons for the variation were outlined in Chapter 6.

The advantage of the Census of Population over the SILC is that it has very detailed information about the types of disabilities people have. The main types of disability in both 2011 and 2016 were 'difficulty with pain, breathing or any other chronic illness or condition', 'difficulty with basic physical activities such as walking, climbing stairs, reaching, lifting or carrying', and a 'psychological or emotional condition'.

In relation to everyday difficulties, 36 per cent of those that reported having a disability in 2016 indicated that they had difficulty undertaking work/study. This was followed by difficulty undertaking other activities (30.6 per cent), and difficulty going outside (18.7 per cent). Over a third of those people that reported having a disability in 2016 had more than one disability.

\subsubsection{Disabilities and education and skills}

Human capital, as measured by educational attainment, is a strong predictor of employment. Starting with adults' proficiency in key basic skills, the analysis of the 2012 OECD PIAAC survey showed that people with a permanent disability had lower average scores in literacy and numeracy than people without disabilities. For the former group the mean scores were 212 and 188 respectively, while for the latter group it was 269 and 258.

Both SILC and the Census of Population show that the education level of the population, regardless of disability status, increased over time. However, both data sources also indicated that there is a much smaller percentage of people with disabilities with a third-level qualification. While both the SILC and Census indicate that this percentage has increased over time, and that the percentage with a primary or lower qualification has decreased, the education gap between people with and without disabilities remains.

Part of the reason why people with disabilities have lower levels of educational attainment is due to their older age profile. Nevertheless, when we examined educational attainment levels by age cohort, we still found that a much smaller percentage of young people (in SILC and Census of Population) with disabilities had a third-level qualification compared to those without. In all European countries there is an over-representation of people with disabilities with lower education levels. However, as a reflection of Ireland's higher level of education overall, Ireland has the second highest proportion of people with disabilities with at least a post-secondary education ( 42 per cent) well above the EU28 average ( 25 per cent). 
While the percentage of those with a primary or lower qualification fell across all disability type groups between 2011 and 2016 (Census), and the proportion with a third-level qualification increased, there was substantial variation in educational attainment levels across disability types. Indeed, the Census 2016 showed that it varied a lot from a high percentage for those with a psychological or emotional condition (29.2 per cent), those with deafness or a serious hearing impairment (28.6 per cent), and those with blindness or a serious vision impairment (27.1 per cent) to the lowest percentage for those having an intellectual disability (6 per cent).

When we examined the fields of study pursued by people with disabilities in 2016, we found that the areas chosen were quite similar to those without disabilities. Specifically, the top fields were social sciences, business and law, engineering, manufacturing and construction, arts and humanities, and health.

\subsubsection{Disabilities and employment}

Only a third of the working age people with disabilities indicated that their main economic status in 2016 was employment (Census) as compared to two-thirds for persons without disabilities. There was considerable variation in the percentages in employment by disability types. The percentage of working people with disabilities in 2016 was the lowest among those with an intellectual disability (14.7 per cent), those with 'difficulty with basic physical activities such as walking, climbing stairs, reaching, lifting or carrying' (18.1 per cent) and those that have a 'difficulty in learning, remembering or concentrating' (20.7 per cent). The percentage was the largest for those having 'deafness or a serious hearing impairment' (45.7 per cent) or 'blindness or a serious vision impairment' (34 per cent).

The analysis of the SILC data, with a longer-term perspective, highlighted the labour market precarity and unequal exposure of people with disabilities in a situation of economic crisis. Indeed, while the proportion of people at work fell during the Great Recession regardless of disability status, the 2019 SILC figures suggest that people with disabilities did not benefit from the economic recovery to the same extent as those without as they were not back at their pre-recession employment levels by 2019.

Compared to other EU countries Ireland does not perform well in relation to the working status of people with disabilities. Specifically, Ireland has the fourth lowest employment rate for people with disabilities (36 per cent), while it is the highest in Estonia (63 per cent). The employment gap in Ireland between people without and with disabilities is also one of the largest across the EU countries. Moreover, unlike most European countries, there is also very little difference in Ireland in the employment rate by severity of disability. This suggests that in Ireland the barriers to work could be related to factors other than the severity of disability. 
Focusing on working people, the SILC analysis showed that people with disability are less likely to work full-time than those without disabilities, and Ireland has the fifth lowest proportion of people with disabilities working part-time in Europe in 2018 (EU-SILC). In addition, people with strong limitations are also found to be less likely to work full-time than those with less limitations (SILC).

The analysis of the Census showed that there is not much variation in the occupational distribution among people of working age with and without disabilities in 2016, nor is there a substantial change in this distribution between 2011 and 2016. There is, however, variation by disability type. For example, people with an intellectual disability are less likely to be managers, directors, or senior officials, or in professional occupations or associate professional and technical occupations in 2016. On the other hand, people with 'deafness or a serious hearing impairment' or with 'blindness of a serious vision impairment' are more likely to be in these positions. There is also very little discrepancy in the economic sectors that people with and without disabilities are employed in 2016, and there is also very little variation by disability type. In 2016, the main sectors of employment were retail, health, and industry.

An econometric analysis of employment using the Census data showed that having a disability had a negative impact on an individual's likelihood of being in employment in both 2011 and 2016, with the negative effect being greater for employees as compared to the self-employed. In both instances, the negative effect is slightly larger for males. The impact of having a disability on a person's employment chances varies also by disability type. Specifically, people with a 'psychological or emotional condition' or 'difficulty with basic physical activities such as walking, climbing stairs, reaching, lifting or carrying' are most severely impacted, in terms of either being an employee or self-employed. For all disability types, the negative effect is slightly larger among males.

\subsubsection{Disabilities and poverty}

The economic literature on poverty shows that the most protective factor against poverty and social exclusion is being at work, and both SILC and EU-SILC surveys provide information to explore such relationship for people without and with disabilities. Both surveys show that in Ireland and in all European countries, people with disabilities are much more likely to experience poverty and social exclusion than people without disabilities. While being employed reduces to a large extent the risk of poverty overall, employed people with disabilities are still experiencing higher poverty risks than employed people without disabilities. Again, this is true in all European countries but with some large variation across countries as the contrast can be quite sharp in some countries like Ireland. Indeed, the at risk of poverty rate in Ireland for employed people without disabilities is one of the lowest while, on average, it is much higher for people with disabilities. Also, the difference in Ireland in the at risk of poverty rate between people without disabilities and 
people with disabilities that are unemployed or inactive is one of the largest across EU countries.

\subsubsection{Limitation and further research}

In this report we explored the characteristics of people with and without disabilities, and how they might translate into employment outcomes. The analysis highlighted the education and employment gaps between people with and without disabilities. While the analysis relied on different datasets and different measures of disability, each data source highlighted the strong disadvantages experienced by people with disabilities in many areas, from education and the labour market to a greater exposure to poverty and social exclusion.

The European comparison of disabilities relies on a subjective measure of disability and cultural factors, but also the level and quality of provision of social welfare services could also affect people's willingness to report any disability. For these reasons, one has to be careful in comparing and interpreting results about disabilities across countries, as a rigorous analysis would require a good knowledge of national institutions in order to fully understand cross-country differences, which is beyond the scope of this report.

Another caveat with the examinations conducted within this report that needs to be borne in mind is the age of some of the data used, and this specifically relates to the PIAAC data which dates from 2012. There is also a strong limitation in the PIAAC survey with the way the information of disability is collected with a restrictive definition of disability implying also some notion of severity. The information about people's disability status should be collected independently to their employment and economic status with separate questions. A pilot of this survey was planned by the CSO for 2020. However, this pilot was put on hold because of COVID-19, and this continues to be the status for that survey. COVID-19 also impacted the collection of the 2021 Census. However, this is scheduled to take place in 2022. Thus, consideration should be given to updating the Census examination conducted within this report at that time point. This is so that one can identify the impact of policies that might have been implemented by the Government since the last Census was conducted in 2016 to support people with disabilities to gain employment.

The analysis highlighted the gaps in labour market outcomes between people without and with disabilities, and also poverty outcomes. A comparative analysis of the earnings and other sources of income of employed people with and without disabilities would contribute to deepening our knowledge about the various outcomes we have observed and their consequences. This would provide a good insight about earnings inequality (if any) between people without and with disabilities that share the same characteristics. This will also improve our understanding and will highlight the role that social protection can play to support 
the income of working people with disabilities, as they are exposed to much greater risk of poverty than working people without disabilities.

It would be also very useful and informative to do qualitative research in order to get a better understanding of the labour market experience of people with disabilities particularly about those trying to gain a foothold in it. Specifically, such research should engage with key stakeholders, including persons with lived experience of disability. Such research was outside of the scope of the current study, the objective of which was to examine existing secondary data sources to provide quantitative evidence on the education and labour market profiles of people with and without disabilities. Nevertheless, the combination of quantitative and qualitative research can provide valuable insights information for policymakers to develop appropriate supports needed by people with disabilities to gain employment. In addition to looking at the labour market experience of people with disabilities from qualitative research, it would be important also to include case studies with employers to better understand their needs to facilitate an increase of their employment of people with disabilities. This type of work was recently undertaken by the OECD in a study on the employment of persons with disabilities in Ireland. ${ }^{46}$

In Chapter 1 we described the progress that has been achieved within the education system to support people with disabilities over the last decade. Nevertheless, our findings in this report still highlight inequality for accessing thirdlevel qualifications for young people with disabilities compared to their counterparts with no disabilities. The lack of supports for transitions from secondlevel to further education and training or employment has been identified as a barrier by Scanlon et al. (2020). This is coupled with the lack of career guidance for many students with disabilities prior to leaving school. Work around improving transition supports is ongoing through the CES, but there is room for further qualitative research to explore some barriers more fully.

In this report we highlighted that considerable progress has been made within the education system over the last decade to support people with disabilities. Nevertheless, it is important to provide opportunities to people with disabilities as they move from the education system to the labour market. Otherwise, the full return on such investments made by the education sector will not be achieved, and this, ultimately, will be a cost borne by individuals with disabilities but as well by society overall. 


\section{REFERENCES}

Australian Bureau of Statistics (2016). Disability, ageing and careers, Australia: Summary of findings, 2015. http://www.abs.gov.au/ausstats/abs@.nsf/Lookup/4430.0main+ features202015.

Bratsberg, B., E. Fevang and K. Røed (2010). Disability in the Welfare State: An Unemployment Problem in Disguise? Bonn, Germany: Institute for the Study of Labor (IZA).

Cai L. and G. Kalb (2006). 'Health status and labour force participation: evidence from Australia', Health Economics. Mar;15(3):241-61.

CSO (2017). Census of Population 2016 - Profile 10 Education, Skills and the Irish Language, Cork.

Central Statistics Office (2013). PIAAC 2012: Survey Results for Ireland from the OECD'S Programme for the International Assessment of Adult Competencies. Dublin: CSO.

Delaney, L., P. Wall and F. O'hAodha (2007). 'Social capital and self-rated health in the Republic of Ireland: evidence from the European Social survey'. Ir Med J. Sep; 100(8): suppl 52-6.

Department of Employment Affairs and Social Protection (2020). Roadmap for social inclusion 2020-2025, Dublin: Department of Employment Affairs and Social Protection.

Department of Employment Affairs and Social Protection (DEASP) (2019). Social inclusion monitor 2017, Dublin: Department of Employment Affairs and Social Protection.

Esping-Andersen, G. (1990). The Three Worlds of Welfare Capitalism. Cambridge: Polity Press.

Eurostat (2015). 'Employment of disabled people. Statistical analysis of the 2011 Labour Force Survey ad hoc module'. Serie: Population and Working Conditions. Statistical Working Papers, Luxemburg, Publications Office of the European Union.

Eurostat (2017). 'Disability statistics'. http://ec.europa.eu/ eurostat/statistics explained/index.php?title=Disability_statistics.

Government of Ireland (2007). National Action Plan for Social Inclusion 2007-2016, Dublin: Stationery Office.

Griffin, S. and M. Shevlin (2008). Responding to Special Educational Needs, Dublin: Gill and Macmillan.

Higher Education Authority (2021). Progress Review of the National Access Plan and Priorities to 2021, Dublin: HEA. https://hea.ie/assets/uploads/2019/01/HEA-Progress-Review-2021NAP.pdf. 
Higher Education Authority (2017). Review of the Fund for Students with Disabilities. Dublin: HEA.https://hea.ie/assets/uploads/2017/10/HEAReview-of-the-Fund-for-Students-with-Disabilities.pdf.

Kenny, N., S. McCoy and M. Mihut (2020). 'Special education reforms in Ireland: Changing systems, changing schools', International Journal of Inclusive Education, 23 September 2020. https://www.tandfonline.com/doi/full/10.1080/13603116.2020.1821447 ?src=.

McCoy, S. and E. Carroll (forthcoming). Mapping the post-school pathways of young people with special educational needs. National Council for Special Education.

McCoy, S., E. Calvert, E. Smyth and M. Darmody (2010). Study on the costs of participation in higher education, Dublin: HEA. https://www.esri.ie/publications/study-on-the-costs-of-participation-inhigher-education.

McCoy, S., J. Banks and M. Shevlin (2016). 'Insights into the Prevalence of Special Educational Needs', in Williams, J., N. Nixon, E. Smyth and D. Watson (Ed.), Cherishing All the Children Equally? Ireland 100 Years on from the Easter Rising, Chapter 8, pp. 153-174. Microsoft Word - 160922 Children FINAL.docx (esri.ie).

McGinnity, F., H. Russell, D. Watson, G. Kingston and E. Kelly (2014). Winners and Losers? The Equality Impact of the Great Recession in Ireland. Dublin, The Equality Authority and the ESRI.

OECD (2009). OECD Employment Outlook 2009. Tackling the Jobs Crisis. OECD Publishing, Paris.

OECD (2015). Education at a Glance Interim Report: Update of Employment and Educational Attainment Indicators: OECD Indicators, OECD Publishing, Paris.

OECD (2019). Part-time and Partly Equal: Gender and Work in the Netherlands, OECD Publishing, Paris.

OECD (2021). Disability, Work and Inclusion in Ireland: Engaging and supporting employers, OECD Publishing, Paris.

OECD/EU (2018). Health at a Glance: Europe 2018: State of Health in the EU Cycle, OECD Publishing, Paris.

Redmond, P., B. Maître, S. McGuinness and M. Konstantina (2021). A Comparative Assessment of Minimum Wage Employment in Europe. Research Series 123. ESRI. Dublin.

Rege, M., K. Telle and M. Votruba (2005). 'The Effect of Plant Downsizing on Disability Pension Utilization'. Discussion Papers No. 435, Statistics Norway, Research Department.

Roantree, B., B. Maître, I. Privalko and A. McTague (2021). Poverty, Income Inequality and Living Standards in Ireland, Research Series, Economic and Social Research Institute (ESRI). 
Scanlon, G., Y. Barnes-Holmes, M. Shevlin and C. McGuckin (2020). Transition for pupils with special educational needs. 1st ed. Oxford: Peter Lang Ltd.

SOLAS (2020). FET in numbers 2019. Learners with disabilities. www.solas.ie/f/70398/x/a4dcab3b27/disabilities-fet-report-2019.pdf.

Stevens, P. and M. O'Moore (2009). Inclusion or Illusion? Educational Provision for Primary School Children with Mild General Learning Disabilities. Dublin: Blackhall Publishing.

Watson, D., B. Maître and C.T. Whelan (2012). Work and Poverty in Ireland: An Analysis of the CSO Survey on Income and Living Conditions 2004-2010. Social Inclusion Report No.3. ESRI and Department of Social Protection, Dublin.

Watson, D., B. Maître and H. Russell (2015). Workplace Risks and Worker Outcomes in Ireland from a Comparative Perspective: An Analysis of the European Working Conditions Survey, 2005 and 2010. Economic and Social Research Institute Research Series 46. 



\section{APPENDIX}

TABLE A.1 DEMOGRAPHIC PROFILE OF PEOPLE WITH AND WITHOUT DISABILITIES: 2011 (\%)

\begin{tabular}{|c|c|c|}
\hline & \multicolumn{2}{|c|}{2011} \\
\hline & No Disability & Disability \\
\hline \multicolumn{3}{|l|}{ Gender: } \\
\hline Male & 49.6 & 50.7 \\
\hline Female & 50.4 & 49.4 \\
\hline \multicolumn{3}{|l|}{ Age: } \\
\hline $15-19$ & 9.5 & 6.7 \\
\hline $20-24$ & 10.1 & 6.5 \\
\hline $25-34$ & 25.6 & 16.0 \\
\hline $35-44$ & 23.0 & 19.6 \\
\hline $45-54$ & 18.3 & 23.4 \\
\hline $55-64$ & 13.5 & 27.8 \\
\hline \multicolumn{3}{|l|}{ General Health: } \\
\hline Good/Very Good & 94.4 & 55.0 \\
\hline Fair & 3.6 & 34.0 \\
\hline Bad/Very Bad & 0.2 & 10.0 \\
\hline Not Stated & 1.8 & 1.0 \\
\hline \multicolumn{3}{|l|}{ Ethnicity: } \\
\hline White & 94.0 & 96.5 \\
\hline Other & 4.4 & 2.7 \\
\hline Not Stated & 1.6 & 0.8 \\
\hline \multicolumn{3}{|l|}{ Nationality: } \\
\hline Irish & 82.7 & 88.4 \\
\hline Non-Irish & 16.4 & 10.9 \\
\hline Not Stated & 1.0 & 0.7 \\
\hline \multicolumn{3}{|l|}{ Marital Status: } \\
\hline Single & 46.7 & 45.2 \\
\hline Married & 46.7 & 41.6 \\
\hline Divorced/Separated & 5.3 & 10.6 \\
\hline Widowed & 1.3 & 2.6 \\
\hline \multicolumn{3}{|l|}{ Geographic Location: } \\
\hline Border & 8.2 & 8.2 \\
\hline West & 9.7 & 9.0 \\
\hline Mid-West & 10.0 & 10.7 \\
\hline South-East & 8.6 & 9.2 \\
\hline South-West & 14.4 & 14.5 \\
\hline Dublin & 29.0 & 28.6 \\
\hline Mid-East & 14.2 & 13.5 \\
\hline Midland & 6.0 & 6.3 \\
\hline
\end{tabular}


TABLE A.2 EDUCATIONAL ATTAINMENT BY AGE COHORT: 2011 (\%)

\begin{tabular}{|l|c|c|}
\hline & \multicolumn{2}{|c|}{ 15-29 Years of Age } \\
\hline & No Disability & Disability \\
\hline Primary or lower & 3.2 & 14.6 \\
\hline Lower secondary & 10.9 & 19.3 \\
\hline Upper Secondary & 37.6 & 35.5 \\
\hline Third-level & 43.9 & 26.9 \\
\hline Not Stated & 4.4 & 3.8 \\
\hline & \multicolumn{2}{|c|}{$30-64$ Years of Age } \\
\hline Primary or lower & No Disability & Disability \\
\hline Lower secondary & 8.7 & 25.5 \\
\hline Upper Secondary & 17.4 & 22.2 \\
\hline Third-level & 29.7 & 24.7 \\
\hline Not Stated & 40.7 & 23.6 \\
\hline
\end{tabular}

Source: Derived by authors using 2011 Census microdata.

Note: Working age population (15-64 years of age) that have ceased education. 
TABLE A.3 FIELD OF STUDY: $2011(\%)$

\begin{tabular}{|c|c|c|c|c|c|c|c|c|c|}
\hline & $\begin{array}{c}\text { No } \\
\text { Disability }\end{array}$ & Disability & $\begin{array}{l}\text { Blindness or a } \\
\text { serious vision } \\
\text { impairment }\end{array}$ & $\begin{array}{c}\text { Deafness or } \\
\text { a serious } \\
\text { hearing } \\
\text { impairment }\end{array}$ & $\begin{array}{c}\text { Difficulty with basic } \\
\text { physical activities such as } \\
\text { walking, climbing stairs, } \\
\text { reaching, lifting or carrying }\end{array}$ & $\begin{array}{c}\text { Intellectual } \\
\text { Disability }\end{array}$ & $\begin{array}{l}\text { Difficulty in } \\
\text { learning, } \\
\text { remembering or } \\
\text { concentrating }\end{array}$ & $\begin{array}{l}\text { Psychological } \\
\text { or emotional } \\
\text { condition }\end{array}$ & $\begin{array}{l}\text { Difficulty with } \\
\text { pain, breathing } \\
\text { or any other } \\
\text { chronic illness } \\
\text { or condition }\end{array}$ \\
\hline Education & 8.9 & 7.7 & 6.5 & 7.9 & 7.6 & 4.3 & 5.7 & 7.3 & 8.2 \\
\hline Arts and humanities & 7.9 & 11.0 & 10.6 & 9.0 & 9.9 & 12.8 & 12.6 & 15.1 & 10.3 \\
\hline $\begin{array}{l}\text { Social sciences, business and } \\
\text { law }\end{array}$ & 29.7 & 26.3 & 28.4 & 25.4 & 24.0 & 20.5 & 21.6 & 27.5 & 26.1 \\
\hline $\begin{array}{l}\text { Science, mathematics, } \\
\text { statistics }\end{array}$ & 4.9 & 4.5 & 4.6 & 4.3 & 3.4 & 3.7 & 3.6 & 5.4 & 4.4 \\
\hline Computing & 5.1 & 5.0 & 5.7 & 4.8 & 4.5 & 5.7 & 5.1 & 5.3 & 4.9 \\
\hline $\begin{array}{l}\text { Engineering, manufacturing } \\
\text { and construction }\end{array}$ & 16.9 & 15.8 & 16.9 & 20.4 & 17.0 & 18.2 & 19.1 & 11.9 & 15.4 \\
\hline Agriculture and veterinary & 2.6 & 2.5 & 2.4 & 3.0 & 2.0 & 3.5 & 3.2 & 2.1 & 2.3 \\
\hline Health & 10.3 & 10.7 & 8.3 & 8.7 & 11.2 & 5.1 & 7.6 & 9.1 & 12.5 \\
\hline Social Services & 2.5 & 3.9 & 3.3 & 3.4 & 4.8 & 3.6 & 4.0 & 4.0 & 4.1 \\
\hline $\begin{array}{l}\text { Services (including other } \\
\text { subjects) }\end{array}$ & 6.5 & 6.6 & 5.9 & 6.3 & 7.0 & 8.2 & 9.0 & 6.6 & 6.3 \\
\hline $\begin{array}{l}\text { Not stated (including } \\
\text { unknown) }\end{array}$ & 4.8 & 6.1 & 7.3 & 6.7 & 8.7 & 14.5 & 8.5 & 5.7 & 5.4 \\
\hline
\end{tabular}

Source: Derived by authors using 2011 Census microdata.

Note: Working age population (15-64 years of age) with a third-level qualification (education ceased). 


\section{TABLE A.4 PERSONAL COMPUTER (PC) AND INTERNET ACCESS: 2011 (\%)}

\begin{tabular}{|c|c|c|}
\hline & No Disability & Disability \\
\hline \multicolumn{3}{|l|}{ PC Usage: } \\
\hline Yes & 83.1 & 69.8 \\
\hline No & 13.2 & 24.2 \\
\hline Not Stated & 3.7 & 6.0 \\
\hline \multicolumn{3}{|l|}{ Broadband Internet Access: } \\
\hline Yes & 74.1 & 61.0 \\
\hline Yes, Other than Broadband & 8.7 & 7.7 \\
\hline No & 13.5 & 25.2 \\
\hline Not Stated & 3.8 & 6.0 \\
\hline
\end{tabular}

Source: Derived by authors using 2011 Census microdata.

Note: Working age population (15-64 years of age) that have ceased education.

TABLE A.5 PERSONAL COMPUTER (PC) AND INTERNET ACCESS BY DISABILITY TYPE: 2011 (\%)

\begin{tabular}{|c|c|c|c|c|c|c|c|}
\hline & $\begin{array}{l}\text { Blindness or } \\
\text { a serious } \\
\text { vision } \\
\text { impairment }\end{array}$ & $\begin{array}{c}\text { Deafness or a } \\
\text { serious } \\
\text { hearing } \\
\text { impairment }\end{array}$ & $\begin{array}{c}\text { Difficulty with basic } \\
\text { physical activities such as } \\
\text { walking, climbing stairs, } \\
\text { reaching, lifting or carrying }\end{array}$ & $\begin{array}{c}\text { Intellectual } \\
\text { Disability }\end{array}$ & $\begin{array}{l}\text { Difficulty in } \\
\text { learning, } \\
\text { remembering or } \\
\text { concentrating }\end{array}$ & $\begin{array}{l}\text { Psychological } \\
\text { or emotional } \\
\text { condition }\end{array}$ & $\begin{array}{l}\text { Difficulty with pain, } \\
\text { breathing or any } \\
\text { other chronic illness } \\
\text { or condition }\end{array}$ \\
\hline \multicolumn{8}{|l|}{ PC Usage: } \\
\hline Yes & 65.0 & 70.5 & 63.8 & 53.5 & 61.8 & 62.9 & 71.4 \\
\hline No & 27.4 & 24.7 & 29.2 & 30.6 & 27.1 & 26.4 & 23.4 \\
\hline Not Stated & 7.6 & 4.9 & 7.0 & 15.9 & 11.1 & 10.7 & 5.2 \\
\hline \multicolumn{8}{|l|}{ Broadband Internet Access: } \\
\hline Yes & 56.6 & 61.8 & 55.2 & 45.6 & 53.1 & 54.4 & 62.6 \\
\hline Yes, other than Broadband & 7.3 & 7.6 & 7.3 & 6.0 & 7.2 & 7.0 & 7.7 \\
\hline No & 28.3 & 25.7 & 30.4 & 32.3 & 28.4 & 27.8 & 24.5 \\
\hline Not Stated & 7.8 & 5.0 & 7.1 & 16.1 & 11.3 & 10.8 & 5.3 \\
\hline
\end{tabular}

Source: Derived by authors using 2011 Census microdata.

Note: Working age population (15-64 years of age) that have ceased education 
TABLE A.6 OCCUPATIONAL DISTRIBUTION: 2011 (\%)

\begin{tabular}{|c|c|c|c|c|c|c|c|}
\hline & $\begin{array}{l}\text { Blindness or a } \\
\text { serious vision } \\
\text { impairment }\end{array}$ & $\begin{array}{l}\text { Deafness or a } \\
\text { serious hearing } \\
\text { impairment }\end{array}$ & \begin{tabular}{|c|} 
Difficulty with basic physical \\
activities such as walking, \\
climbing stairs, reaching, \\
lifting or carrying
\end{tabular} & $\begin{array}{l}\text { Intellectual } \\
\text { Disability }\end{array}$ & $\begin{array}{l}\text { Difficulty in } \\
\text { learning, } \\
\text { remembering or } \\
\text { concentrating }\end{array}$ & $\begin{array}{l}\text { Psychological } \\
\text { or emotional } \\
\text { condition }\end{array}$ & $\begin{array}{l}\text { Difficulty with } \\
\text { pain, breathing or } \\
\text { any other chronic } \\
\text { illness or condition }\end{array}$ \\
\hline $\begin{array}{l}\text { Managers, Directors, Senior } \\
\text { Officials }\end{array}$ & 7.9 & 8.0 & 6.8 & 2.6 & 5.0 & 5.9 & 8.0 \\
\hline Professional Occupations & 13.6 & 12.9 & 11.6 & 3.7 & 6.2 & 15.8 & 18.9 \\
\hline $\begin{array}{l}\text { Associate Professional and } \\
\text { Technical Occupations }\end{array}$ & 9.4 & 11.3 & 9.4 & 4.9 & 8.3 & 11.9 & 11.6 \\
\hline $\begin{array}{l}\text { Administrative and Secretarial } \\
\text { Occupations }\end{array}$ & 12.2 & 11.2 & 14.4 & 4.4 & 6.4 & 14.3 & 12.5 \\
\hline Skilled Trades Occupations & 14.7 & 17.6 & 14.2 & 11.7 & 16.4 & 9.1 & 12.5 \\
\hline $\begin{array}{l}\text { Caring, Leisure and Other } \\
\text { Service Occupations }\end{array}$ & 7.1 & 7.6 & 8.2 & 7.0 & 9.3 & 9.3 & 8.3 \\
\hline $\begin{array}{l}\text { Sales and Customer Service } \\
\text { Occupations }\end{array}$ & 9.3 & 6.3 & 7.5 & 10.4 & 9.2 & 9.0 & 7.2 \\
\hline $\begin{array}{l}\text { Process, Plant and Machine } \\
\text { Operatives }\end{array}$ & 4.5 & 8.0 & 6.8 & 6.4 & 8.5 & 5.4 & 7.0 \\
\hline Elementary Occupations & 13.1 & 11.3 & 10.8 & 20.6 & 16.2 & 9.7 & 9.0 \\
\hline Not Stated & 8.8 & 5.8 & 10.4 & 28.9 & 14.6 & 9.6 & 5.0 \\
\hline
\end{tabular}

Source: Derived by authors using 2011 Census microdata.

Note: Working age population (15-64 years of age) in employment. 
TABLE A.7 ECONOMIC SECTOR OF EMPLOYMENT (\%): 2011

\begin{tabular}{|c|c|c|c|c|c|c|c|}
\hline & $\begin{array}{l}\text { Blindness or a } \\
\text { serious vision } \\
\text { impairment }\end{array}$ & $\begin{array}{l}\text { Deafness or a } \\
\text { serious hearing } \\
\text { impairment }\end{array}$ & $\begin{array}{c}\text { Difficulty with basic physical } \\
\text { activities such as walking, } \\
\text { climbing stairs, reaching, } \\
\text { lifting or carrying }\end{array}$ & $\begin{array}{c}\text { Intellectual } \\
\text { Disability }\end{array}$ & $\begin{array}{l}\text { Difficulty in } \\
\text { learning, } \\
\text { remembering or } \\
\text { concentrating }\end{array}$ & $\begin{array}{l}\text { Psychological } \\
\text { or emotional } \\
\text { condition }\end{array}$ & $\begin{array}{l}\text { Difficulty with } \\
\text { pain, breathing or } \\
\text { any other chronic } \\
\text { illness or } \\
\text { condition }\end{array}$ \\
\hline Agriculture & 5.6 & 5.9 & 6.0 & 4.3 & 5.8 & 3.2 & 4.4 \\
\hline Industry & 10.6 & 11.9 & 8.4 & 6.3 & 8.8 & 7.9 & 9.3 \\
\hline Construction & 4.2 & 5.4 & 3.3 & 2.7 & 4.6 & 2.5 & 3.7 \\
\hline Retail & 15.0 & 13.1 & 13.0 & 15.5 & 15.5 & 13.0 & 13.1 \\
\hline Transport & 2.6 & 4.4 & 4.6 & 2.2 & 4.0 & 3.3 & 4.6 \\
\hline Hotel & 7.0 & 4.4 & 5.2 & 7.8 & 7.6 & 5.1 & 5.0 \\
\hline Communication & 4.0 & 2.9 & 2.5 & 1.5 & 2.4 & 4.3 & 4.1 \\
\hline Finance & 4.5 & 4.2 & 3.2 & 1.5 & 2.4 & 4.8 & 4.9 \\
\hline Technical & 4.5 & 4.5 & 3.4 & 1.6 & 2.6 & 4.7 & 4.8 \\
\hline Administration & 4.2 & 3.8 & 3.9 & 3.5 & 4.5 & 3.8 & 3.6 \\
\hline Public Administration & 7.5 & 8.7 & 8.1 & 3.1 & 4.9 & 7.7 & 7.2 \\
\hline Education & 7.2 & 8.3 & 9.1 & 7.3 & 6.9 & 10.4 & 10.6 \\
\hline Health & 10.5 & 11.2 & 13.2 & 13.8 & 11.0 & 13.8 & 14.0 \\
\hline Arts & 1.9 & 1.9 & 1.8 & 1.7 & 2.2 & 3.1 & 2.0 \\
\hline Other Services & 2.3 & 2.1 & 2.8 & 1.7 & 3.0 & 2.9 & 2.6 \\
\hline Not Stated & 8.5 & 7.3 & 11.6 & 25.5 & 13.8 & 9.8 & 5.9 \\
\hline
\end{tabular}

Source: Derived by authors using 2011 Census microdata.

Note: Working age population (15-64 years of age) in employment. 
TABLE A.8 IMPACT OF DISABILITY ON A PERSON'S PROBABILITY OF BEING AN EMPLOYEE: 2011 (MARGINAL EFFECTS)

\begin{tabular}{|c|c|c|c|}
\hline & $\begin{array}{l}\text { Disability } \\
\text { (1) }\end{array}$ & $\begin{array}{c}\text { Self-Report } \\
\text { General Health } \\
\text { (2) }\end{array}$ & $\begin{array}{c}\text { All Characteristics } \\
\text { (3) }\end{array}$ \\
\hline \multirow[t]{2}{*}{ Disability } & $-0.180 * * *$ & $-0.117^{* * *}$ & $-0.098 * * *$ \\
\hline & $(0.001)$ & $(0.001)$ & $(0.001)$ \\
\hline \multicolumn{4}{|c|}{ General Health (Ref: Very Good/Good): } \\
\hline \multirow[t]{2}{*}{ Fair } & & $-0.178 * * *$ & $-0.143 * * *$ \\
\hline & & $(0.002)$ & $(0.002)$ \\
\hline \multirow[t]{2}{*}{ Bad/Very Bad } & & $-0.273 * * *$ & $-0.234 * * *$ \\
\hline & & $(0.005)$ & $(0.005)$ \\
\hline \multicolumn{4}{|l|}{ Gender (Ref: Female): } \\
\hline \multirow[t]{2}{*}{ Male } & & & $-0.094 * * *$ \\
\hline & & & $(0.001)$ \\
\hline \multicolumn{4}{|l|}{ Age (Ref: Age 35-44): } \\
\hline \multirow[t]{2}{*}{$15-19$} & & & $-0.234 * * *$ \\
\hline & & & $(0.003)$ \\
\hline \multirow[t]{2}{*}{$20-24$} & & & $-0.091 * * *$ \\
\hline & & & $(0.001)$ \\
\hline \multirow[t]{2}{*}{$25-34$} & & & $0.004^{* * *}$ \\
\hline & & & $(0.001)$ \\
\hline \multirow[t]{2}{*}{$45-54$} & & & $-0.021 * * *$ \\
\hline & & & $(0.001)$ \\
\hline \multirow[t]{2}{*}{$55-64$} & & & $-0.223 * * *$ \\
\hline & & & $(0.001)$ \\
\hline \multicolumn{4}{|l|}{ Ethnicity (Ref: Other): } \\
\hline \multirow[t]{2}{*}{ White } & & & $0.068^{* * *}$ \\
\hline & & & $(0.002)$ \\
\hline \multicolumn{4}{|c|}{ Nationality (Ref: Non-Irish): } \\
\hline \multirow[t]{2}{*}{ Irish } & & & $0.016 * * *$ \\
\hline & & & $(0.001)$ \\
\hline \multicolumn{4}{|c|}{ Marital Status (Ref: Single): } \\
\hline \multirow[t]{2}{*}{ Married } & & & $0.093 * * *$ \\
\hline & & & $(0.001)$ \\
\hline \multirow[t]{2}{*}{ Divorced/Separated } & & & -0.000 \\
\hline & & & $(0.001)$ \\
\hline \multirow[t]{2}{*}{ Widowed } & & & $-0.022 * * *$ \\
\hline & & & $(0.003)$ \\
\hline \multicolumn{4}{|c|}{ Geographic Location (Ref: Dublin): } \\
\hline \multirow[t]{2}{*}{ Border } & & & $-0.080 * * *$ \\
\hline & & & $(0.001)$ \\
\hline \multirow[t]{2}{*}{ West } & & & $-0.036 * * *$ \\
\hline & & & $(0.001)$ \\
\hline \multirow[t]{2}{*}{ Mid-West } & & & $-0.055^{* * *}$ \\
\hline & & & $(0.001)$ \\
\hline
\end{tabular}


TABLE A.8 CONTD.

\begin{tabular}{|c|c|c|c|}
\hline & $\begin{array}{l}\text { Disability } \\
\text { (1) }\end{array}$ & $\begin{array}{c}\text { Self-Report } \\
\text { General Health (2) }\end{array}$ & $\begin{array}{c}\text { All Characteristics } \\
\text { (3) }\end{array}$ \\
\hline \multirow[t]{2}{*}{ South-East } & & & $-0.078 * * *$ \\
\hline & & & $(0.001)$ \\
\hline \multirow[t]{2}{*}{ South-West } & & & $-0.024 * * *$ \\
\hline & & & $(0.001)$ \\
\hline \multirow[t]{2}{*}{ Mid-East } & & & $-0.041 * * *$ \\
\hline & & & $(0.001)$ \\
\hline \multirow[t]{2}{*}{ Midland } & & & $-0.079 * * *$ \\
\hline & & & $(0.002)$ \\
\hline Observations & $1,889,146$ & $1,889,146$ & $1,889,146$ \\
\hline Pseudo R-squared & 0.0111 & 0.0194 & 0.0738 \\
\hline
\end{tabular}

Source: Derived by authors using 2011 Census microdata.

Note: $\quad$ Working age population (15-64 years of age) in employment (employees only). 'Not stated' cases controlled for in estimated specifications. 'Ref' $=$ reference category (i.e. the group against which the derived results are compared with). Standard errors in parentheses; $* * * p<0.01,{ }^{* *} p<0.05, * p<0.1$.

TABLE A.9 IMPACT OF DISABILITY ON A PERSON'S PROBABILITY OF BEING AN EMPLOYEE BY GENDER: 2011 (MARGINAL EFFECTS)

\begin{tabular}{|l|l|l|c|}
\hline & All (3) & Males (3) & Females (3) \\
\hline Disability & $-0.098^{* * *}$ & $-0.104^{* * *}$ & $-0.091^{* * *}$ \\
\hline & $(0.001)$ & $(0.002)$ & $(0.002)$
\end{tabular}

Source: Derived by authors using 2011 Census microdata.

Note: Working age population (15-64 years of age) in employment (employees only). Controls for gender, age, ethnicity, nationality, marital status, geographic location and not stated cases included in estimated specifications. 'Ref' = reference category (i.e. the group against which the derived results are compared with). Standard errors in parentheses; ${ }^{* * *} p<0.01,{ }^{* *} p<0.05,{ }^{*} p<0.1$.

TABLE A.10 IMPACT OF DISABILITY TYPE ON A PERSON'S PROBABILITY OF BEING AN EMPLOYEE: 2011 (MARGINAL EFFECTS)

\begin{tabular}{|c|c|c|c|}
\hline & $\begin{array}{l}\text { Disability Type } \\
\text { (1) }\end{array}$ & $\begin{array}{l}\text { Self-Reported } \\
\text { General Health } \\
\text { (2) }\end{array}$ & $\begin{array}{c}\text { All } \\
\text { Characteristics } \\
\text { (3) }\end{array}$ \\
\hline \multicolumn{4}{|l|}{ Disability Type: } \\
\hline \multirow[t]{2}{*}{ Blindness or a serious vision impairment } & $-0.075 * * *$ & $-0.057 * * *$ & $-0.042 * * *$ \\
\hline & $(0.005)$ & $(0.004)$ & $(0.004)$ \\
\hline \multirow[t]{2}{*}{ Deafness or a serious hearing impairment } & $-0.094 * * *$ & $-0.081 * * *$ & $-0.044 * * *$ \\
\hline & $(0.004)$ & $(0.003)$ & $(0.003)$ \\
\hline \multirow[t]{2}{*}{$\begin{array}{l}\text { Difficulty with basic physical activities such a } \\
\text { walking, climbing stairs, reaching, lifting or } \\
\text { carrying }\end{array}$} & $-0.212 * * *$ & $-0.143 * * *$ & $-0.120 * * *$ \\
\hline & $(0.003)$ & $(0.003)$ & $(0.003)$ \\
\hline \multirow[t]{2}{*}{ Intellectual Disability } & $-0.011 * *$ & $-0.009 *$ & $0.010 * *$ \\
\hline & $(0.005)$ & $(0.005)$ & $(0.004)$ \\
\hline \multirow[t]{2}{*}{$\begin{array}{l}\text { Difficulty in learning, remembering or } \\
\text { concentrating }\end{array}$} & $-0.152 * * *$ & $-0.131 * * *$ & $-0.100 * * *$ \\
\hline & $(0.004)$ & $(0.004)$ & $(0.003)$ \\
\hline \multirow[t]{2}{*}{ Psychological or emotional condition } & $-0.156 * * *$ & $-0.114 * * *$ & $-0.126 * * *$ \\
\hline & $(0.003)$ & $(0.003)$ & $(0.003)$ \\
\hline
\end{tabular}


TABLE A.10 CONTD.

\begin{tabular}{|c|c|c|c|}
\hline & $\begin{array}{l}\text { Disability Type } \\
\text { (1) }\end{array}$ & $\begin{array}{l}\text { Self-Reported } \\
\text { General Health } \\
\text { (2) }\end{array}$ & $\begin{array}{c}\text { All } \\
\text { Characteristics } \\
\text { (3) }\end{array}$ \\
\hline \multirow[t]{2}{*}{$\begin{array}{l}\text { Difficulty with pain, breathing or any other chronic } \\
\text { illness or condition }\end{array}$} & $-0.071 * * *$ & $-0.015^{* * *}$ & $-0.016 * * *$ \\
\hline & $(0.002)$ & $(0.002)$ & $(0.002)$ \\
\hline \multicolumn{4}{|l|}{ General Health (Ref: Very Good/Good): } \\
\hline \multirow[t]{2}{*}{ Fair } & & $-0.176 * * *$ & $-0.141 * * *$ \\
\hline & & $(0.002)$ & $(0.002)$ \\
\hline \multirow[t]{2}{*}{ Bad/Very Bad } & & $-0.233 * * *$ & $-0.199 * * *$ \\
\hline & & $(0.006)$ & $(0.005)$ \\
\hline \multicolumn{4}{|l|}{ Gender (Ref: Female): } \\
\hline \multirow[t]{2}{*}{ Male } & & & $-0.094 * * *$ \\
\hline & & & $(0.001)$ \\
\hline \multicolumn{4}{|l|}{ Age (Ref: Age 35-44): } \\
\hline \multirow[t]{2}{*}{$15-19$} & & & $-0.234 * * *$ \\
\hline & & & $(0.003)$ \\
\hline \multirow[t]{2}{*}{$20-24$} & & & $-0.091 * * *$ \\
\hline & & & $(0.001)$ \\
\hline \multirow[t]{2}{*}{$25-34$} & & & $0.004 * * *$ \\
\hline & & & $(0.001)$ \\
\hline \multirow[t]{2}{*}{$45-54$} & & & $-0.021 * * *$ \\
\hline & & & $(0.001)$ \\
\hline \multirow[t]{2}{*}{$55-64$} & & & $-0.223 * * *$ \\
\hline & & & $(0.001)$ \\
\hline \multicolumn{4}{|l|}{ Ethnicity (Ref: Other): } \\
\hline \multirow[t]{2}{*}{ White } & & & $0.068 * * *$ \\
\hline & & & $(0.002)$ \\
\hline \multicolumn{4}{|l|}{ Nationality (Ref: Non-Irish): } \\
\hline \multirow{2}{*}{ Irish } & & & $0.017^{* * *}$ \\
\hline & & & $(0.001)$ \\
\hline \multicolumn{4}{|l|}{ Marital Status (Ref: Single): } \\
\hline \multirow[t]{2}{*}{ Married } & & & $0.092 * * *$ \\
\hline & & & $(0.001)$ \\
\hline \multirow[t]{2}{*}{ Divorced/Separated } & & & 0.000 \\
\hline & & & $(0.001)$ \\
\hline \multirow[t]{2}{*}{ Widowed } & & & $-0.022 * * *$ \\
\hline & & & $(0.003)$ \\
\hline \multicolumn{4}{|l|}{ Geographic Location (Ref: Dublin): } \\
\hline \multirow[t]{2}{*}{ Border } & & & $-0.080 * * *$ \\
\hline & & & $(0.001)$ \\
\hline \multirow[t]{2}{*}{ West } & & & $-0.036 * * *$ \\
\hline & & & $(0.001)$ \\
\hline Mid-West & & & $-0.055^{* * *}$ \\
\hline & & & $(0.001)$ \\
\hline South-East & & & $-0.078 * * *$ \\
\hline & & & $(0.001)$ \\
\hline South-West & & & $-0.024 * * *$ \\
\hline & & & $(0.001)$ \\
\hline Mid-East & & & $-0.042 * * *$ \\
\hline & & & $(0.001)$ \\
\hline
\end{tabular}


TABLE A.10 CONTD.

\begin{tabular}{l|c|c|c}
\hline & $\begin{array}{c}\text { Disability Type } \\
\mathbf{( 1 )}\end{array}$ & $\begin{array}{c}\text { Self-Reported } \\
\text { General Health } \\
\text { (2) }\end{array}$ & $\begin{array}{c}\text { All } \\
\text { Characteristics } \\
\text { (3) }\end{array}$ \\
\hline Midland & & & $-0.079 * * *$ \\
\hline Observations & $1,889,146$ & $1,889,146$ & $(0.002)$ \\
\hline Pseudo R-squared & 0.0134 & 0.0208 & 0.0748 \\
\hline
\end{tabular}

Source: Derived by authors using 2011 Census microdata.

Note: Working age population (15-64 years of age) in employment (employees only). 'Not stated' cases controlled for in estimated specifications. 'Ref' = reference category (i.e. the group against which the derived results are compared with). Standard errors in parentheses; ${ }^{* * *} p<0.01,{ }^{* *} p<0.05, * p<0.1$.

TABLE A.11 IMPACT OF DISABILITY TYPE ON A PERSON'S PROBABILITY OF BEING AN EMPLOYEE BY GENDER: 2011 (MARGINAL EFFECTS)

\begin{tabular}{|c|c|c|c|}
\hline & $\begin{array}{l}\text { All } \\
\text { (1) }\end{array}$ & $\begin{array}{c}\text { Males } \\
\text { (2) }\end{array}$ & $\begin{array}{c}\text { Females } \\
\text { (3) }\end{array}$ \\
\hline \multicolumn{4}{|l|}{ Disability Type: } \\
\hline \multirow[t]{2}{*}{ Blindness or a serious vision impairment } & $-0.042 * * *$ & $-0.043 * * *$ & $-0.037 * * *$ \\
\hline & $(0.004)$ & $(0.006)$ & $(0.006)$ \\
\hline \multirow[t]{2}{*}{ Deafness or a serious hearing impairment } & $-0.044 * * *$ & $-0.052 * * *$ & $-0.040 * * *$ \\
\hline & $(0.003)$ & $(0.005)$ & $(0.005)$ \\
\hline \multirow[t]{2}{*}{$\begin{array}{l}\text { Difficulty with basic physical activities such as } \\
\text { walking, climbing stairs, reaching, lifting or carrying }\end{array}$} & $-0.120 * * *$ & $-0.130 * * *$ & $-0.107 * * *$ \\
\hline & $(0.003)$ & $(0.005)$ & $(0.004)$ \\
\hline \multirow[t]{2}{*}{ Intellectual Disability } & $0.010 * *$ & $0.025^{* * *}$ & -0.009 \\
\hline & $(0.004)$ & $(0.006)$ & $(0.007)$ \\
\hline \multirow[t]{2}{*}{$\begin{array}{l}\text { Difficulty in learning, remembering or } \\
\text { concentrating }\end{array}$} & $-0.100 * * *$ & $-0.108 * * *$ & $-0.088 * * *$ \\
\hline & $(0.003)$ & $(0.005)$ & $(0.005)$ \\
\hline \multirow[t]{2}{*}{ Psychological or emotional condition } & $-0.126 * * *$ & $-0.125 * * *$ & $-0.124 * * *$ \\
\hline & $(0.003)$ & $(0.005)$ & $(0.004)$ \\
\hline \multirow[t]{2}{*}{$\begin{array}{l}\text { Difficulty with pain, breathing or any other chronic } \\
\text { illness or condition }\end{array}$} & $-0.016 * * *$ & $-0.022 * * *$ & $-0.012 * * *$ \\
\hline & $(0.002)$ & $(0.003)$ & $(0.002)$ \\
\hline
\end{tabular}

Source: Derived by authors using 2011 Census microdata.

Note: Working age population (15-64 years of age) in employment (employees only). Controls for gender, age, ethnicity, nationality, marital status, geographic location and not stated cases included in estimated specifications. 'Ref' = reference category (i.e. the group against which the derived results are compared with). Standard errors in parentheses; $* * * p<0.01, * * p<0.05, * p<0.1$. 
TABLE A.12 IMPACT OF DISABILITY ON A PERSON'S PROBABILITY OF BEING AN EMPLOYEE, WITH INDIVIDUALS WITH AN INTELLECTUAL DISABILITY EXCLUDED AND CONTROLLING FOR EDUCATIONAL ATTAINMENT: 2016 (MARGINAL EFFECTS)

\begin{tabular}{|c|c|c|}
\hline & $\begin{array}{c}\text { All Characteristics: } \\
\text { Less Educational Attainment } \\
\text { (3) }\end{array}$ & $\begin{array}{l}\text { All Characteristics: } \\
\text { With Educational Attainment } \\
\text { (4) }\end{array}$ \\
\hline \multirow[t]{2}{*}{ Disability } & $-0.094 * * *$ & $-0.084^{* * *}$ \\
\hline & $(0.001)$ & $(0.001)$ \\
\hline \multicolumn{3}{|c|}{ General Health (Ref: Very Good/Good): } \\
\hline \multirow{2}{*}{ Fair } & $-0.138 * * *$ & $-0.106 * * *$ \\
\hline & $(0.001)$ & $(0.001)$ \\
\hline \multirow[t]{2}{*}{ Bad/Very Bad } & $-0.238 * * *$ & $-0.189 * * *$ \\
\hline & $(0.005)$ & $(0.005)$ \\
\hline \multicolumn{3}{|l|}{ Gender (Ref: Female): } \\
\hline \multirow[t]{2}{*}{ Male } & $-0.024 * * *$ & $-0.010 * * *$ \\
\hline & $(0.000)$ & $(0.000)$ \\
\hline \multicolumn{3}{|l|}{ Age (Ref: Age 35-44): } \\
\hline \multirow[t]{2}{*}{$15-19$} & $-0.164 * * *$ & $-0.105^{* * *}$ \\
\hline & $(0.003)$ & $(0.003)$ \\
\hline \multirow[t]{2}{*}{$20-24$} & $-0.020 * * *$ & $-0.017^{* * *}$ \\
\hline & $(0.001)$ & $(0.001)$ \\
\hline \multirow[t]{2}{*}{$25-34$} & $0.002 * * *$ & $-0.005^{* * *}$ \\
\hline & $(0.001)$ & $(0.001)$ \\
\hline \multirow[t]{2}{*}{$45-54$} & $-0.032 * * *$ & $-0.013^{* * *}$ \\
\hline & $(0.001)$ & $(0.001)$ \\
\hline \multirow[t]{2}{*}{$55-64$} & $-0.231 * * *$ & $-0.184 * * *$ \\
\hline & $(0.001)$ & $(0.001)$ \\
\hline \multicolumn{3}{|l|}{ Ethnicity (Ref: Other): } \\
\hline \multirow[t]{2}{*}{ White } & $0.084^{* * *}$ & $0.088^{* * *}$ \\
\hline & $(0.001)$ & $(0.002)$ \\
\hline \multicolumn{3}{|c|}{ Nationality (Ref: Non-Irish): } \\
\hline \multirow[t]{2}{*}{ Irish } & $0.008^{* * *}$ & $0.012^{* * *}$ \\
\hline & $(0.001)$ & $(0.001)$ \\
\hline \multicolumn{3}{|c|}{ Marital Status (Ref: Single): } \\
\hline \multirow[t]{2}{*}{ Married } & $0.083^{* * *}$ & $0.072 * * *$ \\
\hline & $(0.001)$ & $(0.001)$ \\
\hline \multirow[t]{2}{*}{ Divorced/Separated } & $0.020 * * *$ & $0.024 * * *$ \\
\hline & $(0.001)$ & $(0.001)$ \\
\hline \multirow[t]{2}{*}{ Widowed } & $-0.025^{* * *}$ & $-0.006 * * *$ \\
\hline & $(0.002)$ & $(0.002)$ \\
\hline \multicolumn{3}{|c|}{ Geographic Location (Ref: Dublin): } \\
\hline \multirow[t]{2}{*}{ Border } & $-0.060 * * *$ & $-0.041 * * *$ \\
\hline & $(0.001)$ & $(0.001)$ \\
\hline \multirow[t]{2}{*}{ West } & $-0.027 * * *$ & $-0.023 * * *$ \\
\hline & $(0.001)$ & $(0.001)$ \\
\hline
\end{tabular}


TABLE A.12 CONTD.

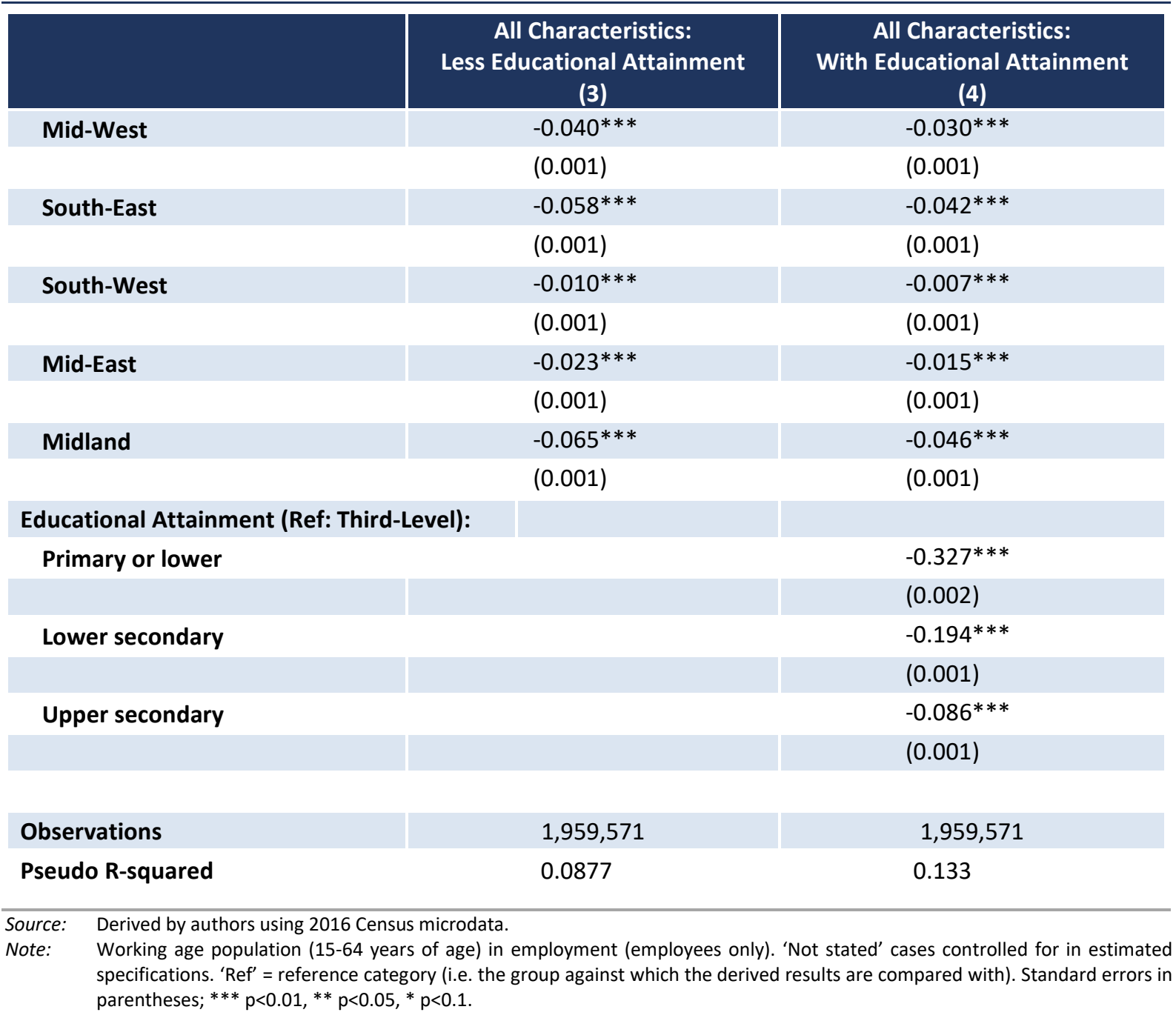


TABLE A.13 IMPACT OF DISABILITY TYPE ON A PERSON'S PROBABILITY OF BEING AN EMPLOYEE, WITH INDIVIDUALS WITH AN INTELLECTUAL DISABILITY EXCLUDED AND CONTROLLING FOR EDUCATIONAL ATTAINMENT: 2016 (MARGINAL EFFECTS)

\begin{tabular}{|c|c|c|}
\hline & $\begin{array}{l}\text { All Characteristics: } \\
\text { Less Educational } \\
\text { Attainment } \\
\text { (3) }\end{array}$ & $\begin{array}{l}\text { All Characteristics: } \\
\text { With Educational } \\
\text { Attainment } \\
\text { (4) }\end{array}$ \\
\hline \multicolumn{3}{|l|}{ Disability Type: } \\
\hline \multirow[t]{2}{*}{ Blindness or a serious vision impairment } & $-0.057 * * *$ & $-0.051 * * *$ \\
\hline & $(0.004)$ & $(0.004)$ \\
\hline \multirow[t]{2}{*}{ Deafness or a serious hearing impairment } & $-0.044 * * *$ & $-0.031 * * *$ \\
\hline & $(0.003)$ & $(0.003)$ \\
\hline \multirow[t]{2}{*}{$\begin{array}{l}\text { Difficulty with basic physical activities such as walking, } \\
\text { climbing stairs, reaching, lifting or carrying }\end{array}$} & $-0.122 * * *$ & $-0.102 * * *$ \\
\hline & $(0.003)$ & $(0.003)$ \\
\hline \multirow[t]{2}{*}{ Difficulty in learning, remembering or concentrating } & $-0.110 * * *$ & $-0.067 * * *$ \\
\hline & $(0.003)$ & $(0.003)$ \\
\hline \multirow[t]{2}{*}{ Psychological or emotional condition } & $-0.122 * * *$ & $-0.127^{* * *}$ \\
\hline & $(0.003)$ & $(0.003)$ \\
\hline \multirow[t]{2}{*}{$\begin{array}{l}\text { Difficulty with pain, breathing or any other chronic illness } \\
\text { or condition }\end{array}$} & $-0.009 * * *$ & $-0.017^{* * *}$ \\
\hline & $(0.001)$ & $(0.001)$ \\
\hline \multicolumn{3}{|l|}{ General Health (Ref: Very Good/Good): } \\
\hline \multirow[t]{2}{*}{ Fair } & $-0.135 * * *$ & $-0.103 * * *$ \\
\hline & $(0.002)$ & $(0.001)$ \\
\hline \multirow[t]{2}{*}{ Bad/Very Bad } & $-0.199 * * *$ & $-0.155^{* * *}$ \\
\hline & $(0.005)$ & $(0.005)$ \\
\hline \multicolumn{3}{|l|}{ Gender (Ref: Female): } \\
\hline \multirow[t]{2}{*}{ Male } & $-0.024 * * *$ & $-0.010^{* * *}$ \\
\hline & $(0.001)$ & $(0.000)$ \\
\hline \multicolumn{3}{|l|}{ Age (Ref: Age 35-44): } \\
\hline \multirow[t]{2}{*}{$15-19$} & $-0.163 * * *$ & $-0.105^{* * *}$ \\
\hline & $(0.003)$ & $(0.003)$ \\
\hline \multirow[t]{2}{*}{$20-24$} & $-0.020 * * *$ & $-0.017 * * *$ \\
\hline & $(0.001)$ & $(0.001)$ \\
\hline \multirow[t]{2}{*}{$25-34$} & $0.002 * * *$ & $-0.005^{* * *}$ \\
\hline & $(0.001)$ & $(0.001)$ \\
\hline \multirow[t]{2}{*}{$45-54$} & $-0.032 * * *$ & $-0.014^{* * *}$ \\
\hline & $(0.001)$ & $(0.001)$ \\
\hline \multirow[t]{2}{*}{$55-64$} & $-0.231 * * *$ & $-0.185^{* * *}$ \\
\hline & $(0.001)$ & $(0.001)$ \\
\hline \multicolumn{3}{|l|}{ Ethnicity (Ref: Other): } \\
\hline \multirow[t]{2}{*}{ White } & $0.084 * * *$ & $0.089 * * *$ \\
\hline & $(0.001)$ & $(0.002)$ \\
\hline
\end{tabular}


TABLE A.13 CONTD.

\begin{tabular}{|c|c|c|}
\hline & $\begin{array}{l}\text { All Characteristics: } \\
\text { Less Educational } \\
\text { Attainment } \\
\text { (3) }\end{array}$ & $\begin{array}{l}\text { All Characteristics: } \\
\text { With Educational } \\
\text { Attainment } \\
\text { (4) }\end{array}$ \\
\hline \multicolumn{3}{|c|}{ Nationality (Ref: Non-Irish): } \\
\hline \multirow[t]{2}{*}{ Irish } & $0.008 * * *$ & $0.013^{* * *}$ \\
\hline & $(0.001)$ & $(0.001)$ \\
\hline \multicolumn{3}{|c|}{ Marital Status (Ref: Single): } \\
\hline \multirow{2}{*}{ Married } & $0.082 * * *$ & $0.071 * * *$ \\
\hline & $(0.001)$ & $(0.001)$ \\
\hline \multirow[t]{2}{*}{ Divorced/Separated } & $0.020 * * *$ & $0.024 * * *$ \\
\hline & $(0.001)$ & $(0.001)$ \\
\hline \multirow[t]{2}{*}{ Widowed } & $-0.025^{* * *}$ & $-0.007^{* * *}$ \\
\hline & $(0.002)$ & $(0.002)$ \\
\hline \multicolumn{3}{|c|}{ Geographic Location (Ref: Dublin): } \\
\hline \multirow[t]{2}{*}{ Border } & $-0.060 * * *$ & $-0.041 * * *$ \\
\hline & $(0.001)$ & $(0.001)$ \\
\hline \multirow[t]{2}{*}{ West } & $-0.027^{* * *}$ & $-0.023 * * *$ \\
\hline & $(0.001)$ & $(0.001)$ \\
\hline \multirow[t]{2}{*}{ Mid-West } & $-0.040 * * *$ & $-0.030 * * *$ \\
\hline & $(0.001)$ & $(0.001)$ \\
\hline \multirow[t]{2}{*}{ South-East } & $-0.058 * * *$ & $-0.042 * * *$ \\
\hline & $(0.001)$ & $(0.001)$ \\
\hline \multirow[t]{2}{*}{ South-West } & $-0.010 * * *$ & $-0.007 * * *$ \\
\hline & $(0.001)$ & $(0.001)$ \\
\hline \multirow[t]{2}{*}{ Mid-East } & $-0.023^{* * *}$ & $-0.015^{* * *}$ \\
\hline & $(0.001)$ & $(0.001)$ \\
\hline \multirow[t]{2}{*}{ Midland } & $-0.065 * * *$ & $-0.046 * * *$ \\
\hline & $(0.001)$ & $(0.001)$ \\
\hline \multicolumn{3}{|c|}{ Educational Attainment (Ref: Third-Level): } \\
\hline \multirow[t]{2}{*}{ Primary or lower } & & $-0.326 * * *$ \\
\hline & & $(0.002)$ \\
\hline \multirow[t]{2}{*}{ Lower secondary } & & $-0.194 * * *$ \\
\hline & & $(0.001)$ \\
\hline \multirow[t]{4}{*}{ Upper secondary } & & $-0.086 * * *$ \\
\hline & & $(0.001)$ \\
\hline & & $-0.137^{* * *}$ \\
\hline & & $(0.002)$ \\
\hline Observations & $1,959,571$ & $1,959,571$ \\
\hline Pseudo R-squared & 0.0897 & 0.134 \\
\hline
\end{tabular}

Source: Derived by authors using 2016 Census microdata.

Note: Working age population (15-64 years of age) in employment (employees only). 'Not stated' cases controlled for in estimated specifications. Standard errors in parentheses; ${ }^{* * *} p<0.01,{ }^{* *} p<0.05,{ }^{*} p<0.1$. 
TABLE A.14 IMPACT OF NUMBER OF DISABILITIES ON A PERSON'S PROBABILITY OF EMPLOYMENT: 2016 (MARGINAL EFFECTS)

\begin{tabular}{|c|c|c|}
\hline & Employee & Self-Employment \\
\hline \multicolumn{3}{|c|}{ Disability Number (Ref: None): } \\
\hline \multirow[t]{2}{*}{ One } & $-0.070 * * *$ & $-0.034 * * *$ \\
\hline & $(0.001)$ & $(0.002)$ \\
\hline \multirow[t]{2}{*}{ Two } & $-0.143 * * *$ & $-0.068 * * *$ \\
\hline & $(0.003)$ & $(0.006)$ \\
\hline \multirow[t]{2}{*}{ Three } & $-0.214 * * *$ & $-0.128 * * *$ \\
\hline & $(0.007)$ & $(0.015)$ \\
\hline \multirow[t]{2}{*}{ Four } & $-0.251 * * *$ & $-0.156 * * *$ \\
\hline & $(0.012)$ & $(0.032)$ \\
\hline \multirow[t]{2}{*}{ Five or more } & $-0.219 * * *$ & $-0.107 * * *$ \\
\hline & $(0.017)$ & $(0.038)$ \\
\hline \multicolumn{3}{|c|}{ General Health (Ref: Very Good/Good): } \\
\hline \multirow[t]{2}{*}{ Fair } & $-0.138 * * *$ & $-0.076 * * *$ \\
\hline & $(0.001)$ & $(0.003)$ \\
\hline \multirow[t]{2}{*}{ Bad/Very Bad } & $-0.225^{* * *}$ & $-0.138 * * *$ \\
\hline & $(0.005)$ & $(0.011)$ \\
\hline \multicolumn{3}{|l|}{ Gender (Ref: Female): } \\
\hline \multirow[t]{2}{*}{ Male } & $-0.025^{* * *}$ & $-0.002 *$ \\
\hline & $(0.001)$ & $(0.001)$ \\
\hline \multicolumn{3}{|l|}{ Age (Ref: Age 35-44): } \\
\hline \multirow[t]{2}{*}{$15-19$} & $-0.163 * * *$ & $-0.127 * * *$ \\
\hline & $(0.003)$ & $(0.019)$ \\
\hline \multirow[t]{2}{*}{$20-24$} & $-0.020 * * *$ & $-0.014 * * *$ \\
\hline & $(0.001)$ & $(0.005)$ \\
\hline \multirow[t]{2}{*}{$25-34$} & $0.002^{* * *}$ & $0.007^{* * *}$ \\
\hline & $(0.001)$ & $(0.002)$ \\
\hline \multirow[t]{2}{*}{$45-54$} & $-0.032 * * *$ & $-0.021 * * *$ \\
\hline & $(0.001)$ & $(0.001)$ \\
\hline \multirow[t]{2}{*}{$55-64$} & $-0.230 * * *$ & $-0.087^{* * *}$ \\
\hline & $(0.001)$ & $(0.002)$ \\
\hline \multicolumn{3}{|l|}{ Ethnicity (Ref: Other): } \\
\hline \multirow[t]{2}{*}{ White } & $0.084^{* * *}$ & $0.029 * * *$ \\
\hline & $(0.002)$ & $(0.003)$ \\
\hline \multicolumn{3}{|c|}{ Nationality (Ref: Non-Irish): } \\
\hline \multirow[t]{2}{*}{ Irish } & $0.007^{* * *}$ & $0.036 * * *$ \\
\hline & $(0.001)$ & $(0.002)$ \\
\hline \multicolumn{3}{|c|}{ Marital Status (Ref: Single): } \\
\hline \multirow[t]{2}{*}{ Married } & $0.083^{* * *}$ & $0.040 * * *$ \\
\hline & $(0.001)$ & $(0.001)$ \\
\hline \multirow[t]{2}{*}{ Divorced/Separated } & $0.020 * * *$ & $-0.015^{* * *}$ \\
\hline & $(0.001)$ & $(0.002)$ \\
\hline \multirow[t]{2}{*}{ Widowed } & $-0.025 * * *$ & $-0.052 * * *$ \\
\hline & $(0.002)$ & $(0.004)$ \\
\hline
\end{tabular}


TABLE A.14 CONTD.

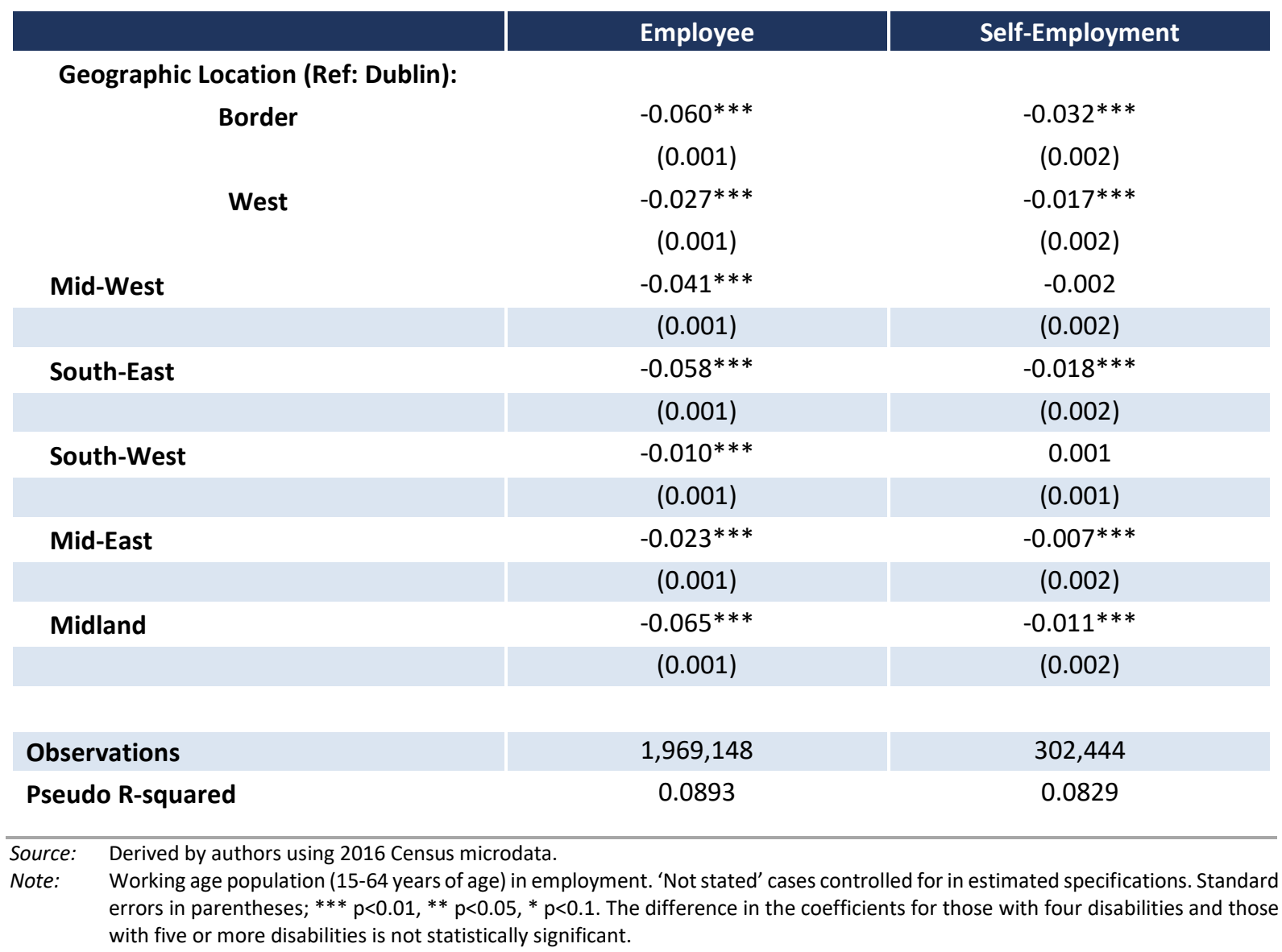


TABLE A.15 IMPACT OF DISABILITY ON A PERSON'S PROBABILITY OF BEING AN EMPLOYEE BY AGE COHORT: 2016 (MARGINAL EFFECTS)

\begin{tabular}{|c|c|c|c|c|c|c|c|}
\hline & All & $\begin{array}{l}\text { Aged } \\
15-19\end{array}$ & $\begin{array}{l}\text { Aged } \\
20-24\end{array}$ & $\begin{array}{l}\text { Aged } \\
25-34\end{array}$ & $\begin{array}{l}\text { Aged } \\
35-44\end{array}$ & $\begin{array}{l}\text { Aged } \\
45-54\end{array}$ & $\begin{array}{l}\text { Aged } \\
55-64\end{array}$ \\
\hline \multirow[t]{2}{*}{ Disability } & $-0.099 * * *$ & $-0.127 * * *$ & $-0.113^{* * *}$ & $-0.097 * * *$ & $-0.081 * * *$ & $-0.089 * * *$ & $-0.128 * * *$ \\
\hline & $(0.001)$ & $(0.012)$ & $(0.005)$ & $(0.002)$ & $(0.002)$ & $(0.002)$ & $(0.003)$ \\
\hline \multicolumn{8}{|c|}{ General Health (Ref: Very Good/Good): } \\
\hline \multirow[t]{2}{*}{ Fair } & $-0.139 * * *$ & $-0.170 * * *$ & $-0.128 * * *$ & $-0.124 * * *$ & $-0.119 * * *$ & $-0.144 * * *$ & $-0.167 * * *$ \\
\hline & $(0.001)$ & $(0.020)$ & $(0.007)$ & $(0.003)$ & $(0.003)$ & $(0.003)$ & $(0.003)$ \\
\hline \multirow[t]{2}{*}{$\begin{array}{l}\text { Bad/ } \\
\text { Very Bad }\end{array}$} & $-0.239 * * *$ & $-0.271 * * *$ & $-0.194 * * *$ & $-0.192 * * *$ & $-0.214 * * *$ & $-0.260 * * *$ & $-0.274 * * *$ \\
\hline & $(0.005)$ & $(0.057)$ & $(0.026)$ & $(0.012)$ & $(0.009)$ & $(0.010)$ & $(0.009)$ \\
\hline \multicolumn{8}{|c|}{ Gender (Ref: Female): } \\
\hline \multirow[t]{2}{*}{ Male } & $-0.025 * * *$ & 0.008 & $-0.029 * * *$ & $-0.022 * * *$ & $-0.019 * * *$ & $-0.038 * * *$ & $-0.022 * * *$ \\
\hline & $(0.001)$ & $(0.006)$ & $(0.002)$ & $(0.001)$ & $(0.001)$ & $(0.001)$ & $(0.002)$ \\
\hline \multicolumn{8}{|c|}{ Age (Ref: Age 35-44): } \\
\hline \multirow[t]{2}{*}{$15-19$} & $-0.164 * * *$ & & & & & & \\
\hline & $(0.003)$ & & & & & & \\
\hline \multirow[t]{2}{*}{$20-24$} & $-0.020 * * *$ & & & & & & \\
\hline & $(0.001)$ & & & & & & \\
\hline \multirow[t]{2}{*}{$25-34$} & $0.002 * *$ & & & & & & \\
\hline & $(0.001)$ & & & & & & \\
\hline \multirow[t]{2}{*}{$45-54$} & $-0.032 * * *$ & & & & & & \\
\hline & $(0.001)$ & & & & & & \\
\hline \multirow[t]{2}{*}{$55-64$} & $-0.231 * * *$ & & & & & & \\
\hline & $(0.001)$ & & & & & & \\
\hline \multicolumn{8}{|c|}{ Ethnicity (Ref: Other): } \\
\hline \multirow[t]{2}{*}{ White } & $0.084 * * *$ & $0.114^{* * *}$ & $0.078 * * *$ & $0.085^{* * *}$ & $0.085^{* * *}$ & $0.074 * * *$ & $-0.014 * *$ \\
\hline & $(0.002)$ & $(0.017)$ & $(0.006)$ & $(0.003)$ & $(0.002)$ & $(0.003)$ & $(0.007)$ \\
\hline \multicolumn{8}{|c|}{ Nationality (Ref: Non-Irish): } \\
\hline \multirow[t]{2}{*}{ Irish } & $0.008 * * *$ & $-0.086 * * *$ & $-0.043 * * *$ & $-0.007 * * *$ & $0.016 * * *$ & $0.021 * * *$ & $0.020 * * *$ \\
\hline & $(0.001)$ & $(0.008)$ & $(0.003)$ & $(0.001)$ & $(0.001)$ & $(0.002)$ & $(0.003)$ \\
\hline \multicolumn{8}{|c|}{ Marital Status (Ref: Single): } \\
\hline \multirow[t]{2}{*}{ Married } & $0.084 * * *$ & $-0.174 * * *$ & $-0.206 * * *$ & $0.039 * * *$ & $0.097 * * *$ & $0.121 * * *$ & $0.098 * * *$ \\
\hline & $(0.001)$ & $(0.027)$ & $(0.008)$ & $(0.001)$ & $(0.001)$ & $(0.001)$ & $(0.003)$ \\
\hline \multirow[t]{2}{*}{$\begin{array}{l}\text { Divorced/ } \\
\text { Separated }\end{array}$} & $0.020 * * *$ & $-0.396 * * *$ & $-0.255^{* * *}$ & $-0.033 * * *$ & $0.019 * * *$ & $0.022 * * *$ & $0.061 * * *$ \\
\hline & $(0.001)$ & $(0.116)$ & $(0.031)$ & $(0.004)$ & $(0.001)$ & $(0.001)$ & $(0.003)$ \\
\hline \multirow[t]{2}{*}{ Widowed } & $-0.025 * * *$ & $0.147^{*}$ & $-0.095 * *$ & $-0.152 * * *$ & $-0.044 * * *$ & $-0.012 * * *$ & $-0.036 * * *$ \\
\hline & $(0.002)$ & $(0.079)$ & $(0.038)$ & $(0.014)$ & $(0.006)$ & $(0.004)$ & $(0.004)$ \\
\hline \multicolumn{8}{|c|}{ Geographic Location (Ref: Dublin): } \\
\hline \multirow[t]{2}{*}{ Border } & $-0.060 * * *$ & $-0.044 * * *$ & $-0.070 * * *$ & $-0.068 * * *$ & $-0.050 * * *$ & $-0.057 * * *$ & $-0.062 * * *$ \\
\hline & $(0.001)$ & $(0.012)$ & $(0.005)$ & $(0.002)$ & $(0.002)$ & $(0.002)$ & $(0.003)$ \\
\hline \multirow[t]{2}{*}{ West } & $-0.027 * * *$ & $-0.037 * * *$ & $-0.035 * * *$ & $-0.032 * * *$ & $-0.016 * * *$ & $-0.026 * * *$ & $-0.026 * * *$ \\
\hline & $(0.001)$ & $(0.012)$ & $(0.004)$ & $(0.002)$ & $(0.002)$ & $(0.002)$ & $(0.003)$ \\
\hline Mid-West & $-0.041 * * *$ & $-0.051 * * *$ & $-0.064 * * *$ & $-0.058 * * *$ & $-0.031 * * *$ & $-0.030 * * *$ & $-0.027 * * *$ \\
\hline & $(0.001)$ & $(0.011)$ & $(0.004)$ & $(0.002)$ & $(0.002)$ & $(0.002)$ & $(0.003)$ \\
\hline South-East & $-0.058 * * *$ & $-0.045^{* * *}$ & $-0.067 * * *$ & $-0.062 * * *$ & $-0.046 * * *$ & $-0.049 * * *$ & $-0.072 * * *$ \\
\hline & $(0.001)$ & $(0.011)$ & $(0.004)$ & $(0.002)$ & $(0.002)$ & $(0.002)$ & $(0.003)$ \\
\hline
\end{tabular}


TABLE A.15 CONTD.

\begin{tabular}{|c|c|c|c|c|c|c|c|}
\hline & All & $\begin{array}{l}\text { Aged } \\
15-19\end{array}$ & $\begin{array}{l}\text { Aged } \\
20-24\end{array}$ & $\begin{array}{l}\text { Aged } \\
25-34\end{array}$ & $\begin{array}{l}\text { Aged } \\
35-44\end{array}$ & $\begin{array}{l}\text { Aged } \\
45-54\end{array}$ & $\begin{array}{l}\text { Aged } \\
55-64\end{array}$ \\
\hline \multirow[t]{2}{*}{ South-West } & $-0.010 * * *$ & 0.010 & $-0.011 * * *$ & $-0.014 * * *$ & $-0.003 * *$ & $-0.007 * * *$ & $-0.017 * * *$ \\
\hline & $(0.001)$ & (0.010) & $(0.003)$ & $(0.002)$ & (0.001) & $(0.002)$ & $(0.003)$ \\
\hline \multirow[t]{2}{*}{ Mid-East } & $-0.023 * * *$ & -0.013 & $-0.033^{* * *}$ & $-0.030 * * *$ & $-0.020 * * *$ & $-0.018 * * *$ & $-0.018 * * *$ \\
\hline & $(0.001)$ & $(0.009)$ & $(0.003)$ & $(0.002)$ & $(0.001)$ & $(0.002)$ & $(0.003)$ \\
\hline \multirow[t]{2}{*}{ Midland } & $-0.065 * * *$ & $-0.091 * * *$ & $-0.097 * * *$ & $-0.081 * * *$ & $-0.052 * * *$ & $-0.053^{* * *}$ & $-0.048 * * *$ \\
\hline & $(0.001)$ & $(0.013)$ & $(0.005)$ & $(0.003)$ & $(0.002)$ & $(0.003)$ & $(0.004)$ \\
\hline Observations & $1,969,148$ & 26,147 & 140,001 & 524,451 & 553,427 & 414,745 & 310,377 \\
\hline $\begin{array}{l}\text { Pseudo } \\
\text { R-squared }\end{array}$ & 0.0893 & 0.0271 & 0.0345 & 0.0342 & 0.0730 & 0.0827 & 0.0388 \\
\hline
\end{tabular}

Source: Derived by authors using 2016 Census microdata.

Note: Working age population (15-64 years of age) in employment (employees only). 'Not stated' cases controlled for in estimated specifications. 'Ref' = reference category (i.e. the group against which the derived results are compared with). Standard errors in parentheses; *** $\mathrm{p}<0.01,{ }^{* *} \mathrm{p}<0.05, * \mathrm{p}<0.1$.

TABLE A.16 IMPACT OF AGE ON A PERSON'S PROBABILITY OF BEING IN EMPLOYMENT BY DISABILITY STATUS: 2016 (MARGINAL EFFECTS)

\begin{tabular}{|c|c|c|c|c|}
\hline & \multicolumn{2}{|c|}{ Employee } & \multicolumn{2}{|c|}{ Self-Employment } \\
\hline & No Disability & Disability & No Disability & Disability \\
\hline \multicolumn{5}{|c|}{ General Health (Ref: Very Good/Good): } \\
\hline \multirow[t]{2}{*}{ Fair } & $-0.142 * * *$ & $-0.174 * * *$ & $-0.082 * * *$ & $-0.100 * * *$ \\
\hline & $(0.002)$ & $(0.003)$ & $(0.003)$ & $(0.006)$ \\
\hline \multirow[t]{2}{*}{ Bad/Very Bad } & $-0.250 * * *$ & $-0.295 * * *$ & $-0.154 * * *$ & $-0.222 * * *$ \\
\hline & $(0.010)$ & $(0.006)$ & $(0.023)$ & $(0.016)$ \\
\hline \multicolumn{5}{|c|}{ Gender (Ref: Female): } \\
\hline \multirow[t]{2}{*}{ Male } & $-0.021 * * *$ & $-0.069 * * *$ & -0.001 & $-0.024 * * *$ \\
\hline & $(0.000)$ & $(0.002)$ & $(0.001)$ & $(0.006)$ \\
\hline \multicolumn{5}{|c|}{ Age (Ref: Age 35-44): } \\
\hline \multirow[t]{2}{*}{$15-19$} & $-0.162 * * *$ & $-0.186 * * *$ & $-0.118 * * *$ & $-0.241 * * *$ \\
\hline & $(0.003)$ & $(0.011)$ & $(0.020)$ & $(0.075)$ \\
\hline \multirow[t]{2}{*}{$20-24$} & $-0.020 * * *$ & $-0.015^{* * *}$ & $-0.014 * * *$ & -0.008 \\
\hline & $(0.001)$ & $(0.006)$ & (0.005) & $(0.026)$ \\
\hline \multirow[t]{2}{*}{$25-34$} & 0.001 & $0.013^{* * *}$ & $0.007 * * *$ & 0.011 \\
\hline & (0.001) & $(0.004)$ & $(0.002)$ & (0.010) \\
\hline \multirow[t]{2}{*}{$45-54$} & $-0.030 * * *$ & $-0.057 * * *$ & $-0.021 * * *$ & $-0.027 * * *$ \\
\hline & (0.001) & $(0.004)$ & (0.001) & (0.008) \\
\hline \multirow[t]{2}{*}{$55-64$} & $-0.227 * * *$ & $-0.270 * * *$ & $-0.085^{* * *}$ & $-0.119 * * *$ \\
\hline & (0.001) & $(0.004)$ & $(0.002)$ & $(0.008)$ \\
\hline \multicolumn{5}{|c|}{ Ethnicity (Ref: Other): } \\
\hline \multirow[t]{2}{*}{ White } & $0.081 * * *$ & $0.100 * * *$ & $0.027 * * *$ & $0.053 * * *$ \\
\hline & (0.002) & (0.007) & (0.003) & (0.016) \\
\hline
\end{tabular}


TABLE A.16 CONTD.

\begin{tabular}{|c|c|c|c|c|}
\hline & \multicolumn{2}{|c|}{ Employee } & \multicolumn{2}{|c|}{ Self-Employment } \\
\hline & No Disability & Disability & No Disability & Disability \\
\hline \multicolumn{5}{|c|}{ Nationality (Ref: Non-Irish): } \\
\hline \multirow[t]{2}{*}{ Irish } & $0.009 * * *$ & $-0.025 * * *$ & $0.035 * * *$ & $0.048 * * *$ \\
\hline & $(0.001)$ & $(0.004)$ & $(0.002)$ & $(0.009)$ \\
\hline \multicolumn{5}{|c|}{ Marital Status (Ref: Single): } \\
\hline \multirow[t]{2}{*}{ Married } & $0.077^{* * *}$ & $0.156 * * *$ & $0.038 * * *$ & $0.074 * * *$ \\
\hline & $(0.001)$ & $(0.003)$ & $(0.001)$ & $(0.007)$ \\
\hline \multirow[t]{2}{*}{ Divorced/ Separated } & $0.018 * * *$ & $0.039 * * *$ & $-0.013 * * *$ & $-0.045 * * *$ \\
\hline & $(0.001)$ & $(0.004)$ & $(0.002)$ & (0.009) \\
\hline \multirow[t]{2}{*}{ Widowed } & $-0.021 * * *$ & $-0.072 * * *$ & $-0.043 * * *$ & $-0.158 * * *$ \\
\hline & $(0.002)$ & $(0.008)$ & $(0.004)$ & $(0.021)$ \\
\hline \multicolumn{5}{|c|}{ Geographic Location (Ref: Dublin): } \\
\hline \multirow[t]{2}{*}{ Border } & $-0.057 * * *$ & $-0.098 * * *$ & $-0.031 * * *$ & $-0.053 * * *$ \\
\hline & $(0.001)$ & $(0.005)$ & $(0.002)$ & $(0.011)$ \\
\hline \multirow[t]{2}{*}{ West } & $-0.025^{* * *}$ & $-0.043 * * *$ & $-0.016 * * *$ & $-0.025^{* *}$ \\
\hline & $(0.001)$ & $(0.005)$ & $(0.002)$ & $(0.010)$ \\
\hline \multirow[t]{2}{*}{ Mid-West } & $-0.038^{* * *}$ & $-0.068 * * *$ & -0.000 & $-0.028 * * *$ \\
\hline & $(0.001)$ & $(0.005)$ & $(0.002)$ & $(0.010)$ \\
\hline \multirow[t]{2}{*}{ South-East } & $-0.054 * * *$ & $-0.092 * * *$ & $-0.015^{* * *}$ & $-0.051 * * *$ \\
\hline & $(0.001)$ & $(0.005)$ & $(0.002)$ & $(0.011)$ \\
\hline \multirow[t]{2}{*}{ South-West } & $-0.009 * * *$ & $-0.025 * * *$ & 0.002 & -0.013 \\
\hline & $(0.001)$ & $(0.004)$ & $(0.001)$ & $(0.009)$ \\
\hline \multirow[t]{2}{*}{ Mid-East } & $-0.023^{* * *}$ & $-0.025 * * *$ & $-0.006 * * *$ & $-0.018^{* *}$ \\
\hline & $(0.001)$ & $(0.004)$ & $(0.002)$ & (0.009) \\
\hline \multirow[t]{2}{*}{ Midland } & $-0.061 * * *$ & $-0.104 * * *$ & $-0.010 * * *$ & -0.013 \\
\hline & $(0.001)$ & $(0.006)$ & $(0.002)$ & $(0.012)$ \\
\hline Observations & $1,814,598$ & 154,550 & 280,539 & 21,905 \\
\hline Pseudo R-squared & 0.0690 & 0.0950 & 0.0664 & 0.0793 \\
\hline
\end{tabular}

Source: Derived by authors using 2016 Census microdata.

Note: Working age population (15-64 years of age) in employment. 'Not stated' cases controlled for in estimated specifications. 'Ref' = reference category (i.e. the group against which the derived results are compared with).

Standard errors in parentheses; ${ }^{* * *} p<0.01, * * p<0.05, * p<0.1$. 
TABLE A.17 IMPACT OF DISABILITY ON A PERSON'S PROBABILITY OF SELF-EMPLOYMENT: 2011 (MARGINAL EFFECTS)

\begin{tabular}{|c|c|c|c|}
\hline & $\begin{array}{c}\text { Disability } \\
\text { (1) }\end{array}$ & $\begin{array}{l}\text { Self-Reported } \\
\text { General Health } \\
\text { (2) }\end{array}$ & $\begin{array}{c}\text { All } \\
\text { Characteristics } \\
\text { (3) }\end{array}$ \\
\hline \multirow[t]{2}{*}{ Disability } & $-0.115^{* * *}$ & $-0.070 * * *$ & $-0.062 * * *$ \\
\hline & $(0.003)$ & $(0.003)$ & $(0.003)$ \\
\hline \multicolumn{4}{|c|}{ General Health (Ref: Very Good/Good): } \\
\hline \multirow[t]{2}{*}{ Fair } & & $-0.114 * * *$ & $-0.088 * * *$ \\
\hline & & $(0.003)$ & $(0.003)$ \\
\hline \multirow[t]{2}{*}{ Bad/Very Bad } & & $-0.207 * * *$ & $-0.174 * * *$ \\
\hline & & $(0.013)$ & $(0.012)$ \\
\hline \multirow[t]{2}{*}{ Not Stated } & & $-0.030 * * *$ & $-0.020 * *$ \\
\hline & & $(0.008)$ & $(0.008)$ \\
\hline \multicolumn{4}{|l|}{ Gender (Ref: Female): } \\
\hline \multirow[t]{2}{*}{ Male } & & & $-0.045^{* * *}$ \\
\hline & & & $(0.001)$ \\
\hline \multicolumn{4}{|l|}{ Age (Ref: Age 35-44): } \\
\hline \multirow[t]{2}{*}{$15-19$} & & & $-0.159 * * *$ \\
\hline & & & $(0.026)$ \\
\hline \multirow[t]{2}{*}{$20-24$} & & & $-0.023^{* * *}$ \\
\hline & & & $(0.006)$ \\
\hline \multirow[t]{2}{*}{ 25-34 } & & & $-0.014^{* * *}$ \\
\hline & & & $(0.002)$ \\
\hline \multirow[t]{2}{*}{$45-54$} & & & 0.002 \\
\hline & & & $(0.002)$ \\
\hline \multirow[t]{2}{*}{$55-64$} & & & $-0.058^{* * *}$ \\
\hline & & & $(0.002)$ \\
\hline \multicolumn{4}{|l|}{ Ethnicity (Ref: Other): } \\
\hline \multirow[t]{2}{*}{ White } & & & $-0.008^{* *}$ \\
\hline & & & $(0.004)$ \\
\hline \multicolumn{4}{|c|}{ Nationality (Ref: Non-Irish): } \\
\hline \multirow[t]{2}{*}{ Irish } & & & $0.060 * * *$ \\
\hline & & & $(0.002)$ \\
\hline \multicolumn{4}{|c|}{ Marital Status (Ref: Single): } \\
\hline \multirow[t]{2}{*}{ Married } & & & $0.046^{* * *}$ \\
\hline & & & $(0.002)$ \\
\hline \multirow[t]{2}{*}{ Divorced/Separated } & & & $-0.047^{* * *}$ \\
\hline & & & $(0.003)$ \\
\hline \multirow[t]{2}{*}{ Widowed } & & & $-0.066 * * *$ \\
\hline & & & $(0.006)$ \\
\hline \multicolumn{4}{|c|}{ Geographic Location (Ref: Dublin): } \\
\hline \multirow[t]{2}{*}{ Border } & & & $-0.059 * * *$ \\
\hline & & & $(0.003)$ \\
\hline \multirow[t]{2}{*}{ West } & & & $-0.032 * * *$ \\
\hline & & & $(0.002)$ \\
\hline
\end{tabular}


TABLE A.17 CONTD.

\begin{tabular}{|l|c|c|c|}
\hline & Disability & $\begin{array}{c}\text { Self-Reported } \\
\text { General Health } \\
\text { (2) }\end{array}$ & $\begin{array}{c}\text { All } \\
\text { Characteristics } \\
\text { (3) }\end{array}$ \\
\hline Mid-West & & -0.003 \\
\hline South-East & & $(0.002)$ \\
\hline South-West & & $-0.037^{* * *}$ \\
\hline Mid-East & & $(0.003)$ \\
\hline Midland & & $-0.005^{* *}$ \\
\hline & & & $(0.002)$ \\
\hline & & $-0.027^{* * *}$ \\
\hline Observations & & & $(0.002)$ \\
\hline Pseudo R-squared & 322,045 & 322,045 & $-0.022^{* * *}$ \\
\hline
\end{tabular}

Source: Derived by authors using 2011 Census microdata.

Note: Working age population (15-64 years of age) in employment (self-employed only).

'Not stated' cases controlled for in estimated specifications.

Standard errors in parentheses; ${ }^{* * *} \mathrm{p}<0.01,{ }^{* *} \mathrm{p}<0.05,{ }^{*} \mathrm{p}<0.1$.

TABLE A.18 IMPACT OF DISABILITY ON A PERSON'S PROBABILITY OF SELF-EMPLOYMENT BY GENDER: 2011 (MARGINAL EFFECTS)

\begin{tabular}{|l|c|c|c|}
\hline & All & Males & Females \\
& $(\mathbf{3})$ & $(\mathbf{3})$ & $\mathbf{( 3 )}$ \\
\hline Disability & $-0.062 * * *$ & $-0.066 * * *$ & $-0.050^{* * *}$ \\
\hline
\end{tabular}

Source: Derived by authors using 2011 Census microdata.

Note: $\quad$ Working age population (15-64 years of age) in employment (self-employed only).

Controls for gender, age, ethnicity, nationality, marital status, geographic location and not stated cases included in estimated specifications.

Standard errors in parentheses; ${ }^{* * *} p<0.01, * * p<0.05, * p<0.1$. 
TABLE A.19 IMPACT OF DISABILITY TYPE ON A PERSON'S PROBABILITY OF SELFEMPLOYMENT: 2011 (MARGINAL EFFECTS)

\begin{tabular}{|c|c|c|c|}
\hline & $\begin{array}{l}\text { Disability } \\
\text { Type } \\
\text { (1) }\end{array}$ & $\begin{array}{l}\text { Self-Reported } \\
\text { General Health } \\
\text { (2) }\end{array}$ & $\begin{array}{c}\text { All } \\
\text { Characteristics } \\
\text { (3) }\end{array}$ \\
\hline \multicolumn{4}{|l|}{ Disability Type: } \\
\hline \multirow[t]{2}{*}{ Blindness or a serious vision impairment } & $-0.069 * * *$ & $-0.060 * * *$ & $-0.050 * * *$ \\
\hline & $(0.010)$ & $(0.010)$ & $(0.009)$ \\
\hline \multirow[t]{2}{*}{ Deafness or a serious hearing impairment } & $-0.068 * * *$ & $-0.062 * * *$ & $-0.048 * * *$ \\
\hline & $(0.007)$ & $(0.006)$ & $(0.006)$ \\
\hline \multirow[t]{2}{*}{$\begin{array}{l}\text { Difficulty with basic physical activities such as walking, } \\
\text { climbing stairs, reaching, lifting or carrying }\end{array}$} & $-0.131 * * *$ & $-0.083^{* * *}$ & $-0.070 * * *$ \\
\hline & $(0.007)$ & $(0.006)$ & $(0.006)$ \\
\hline \multirow[t]{2}{*}{ Intellectual Disability } & $-0.059 * * *$ & $-0.053^{* * *}$ & $-0.044 * * *$ \\
\hline & $(0.016)$ & $(0.016)$ & $(0.015)$ \\
\hline \multirow[t]{2}{*}{ Difficulty in learning, remembering or concentrating } & $-0.084 * * *$ & $-0.067 * * *$ & $-0.060 * * *$ \\
\hline & $(0.008)$ & $(0.008)$ & $(0.007)$ \\
\hline \multirow[t]{2}{*}{ Psychological or emotional condition } & $-0.129 * * *$ & $-0.098 * * *$ & $-0.094 * * *$ \\
\hline & $(0.008)$ & $(0.008)$ & $(0.008)$ \\
\hline \multirow[t]{2}{*}{$\begin{array}{l}\text { Difficulty with pain, breathing or any other chronic } \\
\text { illness or condition }\end{array}$} & $-0.046 * * *$ & $-0.007^{*}$ & $-0.010 * * *$ \\
\hline & $(0.004)$ & $(0.003)$ & $(0.003)$ \\
\hline \multicolumn{4}{|l|}{ General Health (Ref: Very Good/Good): } \\
\hline \multirow[t]{2}{*}{ Fair } & & $-0.114 * * *$ & $-0.088 * * *$ \\
\hline & & $(0.003)$ & $(0.003)$ \\
\hline \multirow[t]{2}{*}{ Bad/Very Bad } & & $-0.184 * * *$ & $-0.154 * * *$ \\
\hline & & $(0.013)$ & $(0.012)$ \\
\hline \multicolumn{4}{|l|}{ Gender (Ref: Female): } \\
\hline \multirow[t]{2}{*}{ Male } & & & $-0.044 * * *$ \\
\hline & & & $(0.001)$ \\
\hline \multicolumn{4}{|l|}{ Age (Ref: Age 35-44): } \\
\hline \multirow[t]{2}{*}{$15-19$} & & & $-0.157^{* * *}$ \\
\hline & & & $(0.026)$ \\
\hline \multirow[t]{2}{*}{$20-24$} & & & $-0.023^{* * *}$ \\
\hline & & & $(0.006)$ \\
\hline \multirow[t]{2}{*}{$25-34$} & & & $-0.014 * * *$ \\
\hline & & & $(0.002)$ \\
\hline \multirow[t]{2}{*}{$45-54$} & & & 0.002 \\
\hline & & & $(0.002)$ \\
\hline \multirow[t]{2}{*}{$55-64$} & & & $-0.058 * * *$ \\
\hline & & & $(0.002)$ \\
\hline \multicolumn{4}{|l|}{ Ethnicity (Ref: Other): } \\
\hline \multirow[t]{2}{*}{ White } & & & $-0.008^{* *}$ \\
\hline & & & $(0.004)$ \\
\hline
\end{tabular}


TABLE A.19 CONTD.

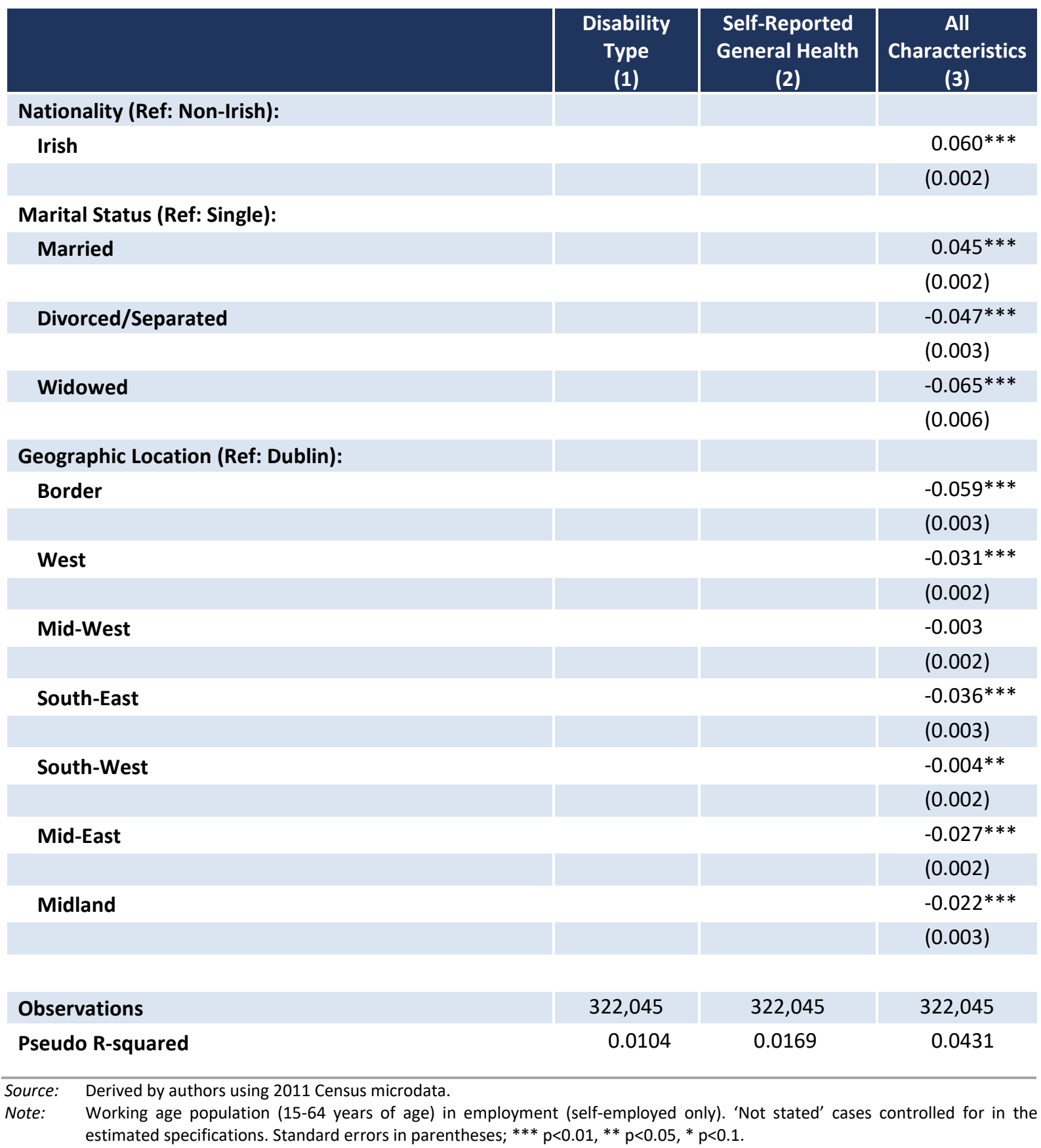


TABLE A.20 IMPACT OF DISABILITY TYPE ON A PERSON'S PROBABILITY OF SELFEMPLOYMENT BY GENDER: 2011 (MARGINAL EFFECTS)

\begin{tabular}{|c|c|c|c|}
\hline & $\begin{array}{l}\text { All } \\
(1)\end{array}$ & $\begin{array}{l}\text { Males } \\
\text { (2) }\end{array}$ & $\begin{array}{l}\text { Females } \\
\text { (3) }\end{array}$ \\
\hline \multicolumn{4}{|l|}{ Disability Type: } \\
\hline \multirow[t]{2}{*}{ Blindness or a serious vision impairment } & $-0.050 * * *$ & $-0.047 * * *$ & $-0.070 * * *$ \\
\hline & (0.009) & $(0.010)$ & $(0.022)$ \\
\hline \multirow[t]{2}{*}{ Deafness or a serious hearing impairment } & $-0.048 * * *$ & $-0.053 * * *$ & $-0.039 * * *$ \\
\hline & $(0.006)$ & $(0.007)$ & $(0.014)$ \\
\hline \multirow[t]{2}{*}{$\begin{array}{l}\text { Difficulty with basic physical activities such as } \\
\text { walking, climbing stairs, reaching, lifting or carrying }\end{array}$} & $-0.070 * * *$ & $-0.073 * * *$ & $-0.056 * * *$ \\
\hline & $(0.006)$ & $(0.007)$ & $(0.011)$ \\
\hline \multirow[t]{2}{*}{ Intellectual Disability } & $-0.044 * * *$ & $-0.050 * * *$ & 0.005 \\
\hline & $(0.015)$ & $(0.017)$ & $(0.031)$ \\
\hline \multirow[t]{2}{*}{ Difficulty in learning, remembering or concentrating } & $-0.060 * * *$ & $-0.068 * * *$ & $-0.030 * *$ \\
\hline & $(0.007)$ & $(0.008)$ & $(0.014)$ \\
\hline \multirow[t]{2}{*}{ Psychological or emotional condition } & $-0.094 * * *$ & $-0.089 * * *$ & $-0.113 * * *$ \\
\hline & $(0.008)$ & $(0.009)$ & $(0.015)$ \\
\hline \multirow[t]{2}{*}{$\begin{array}{l}\text { Difficulty with pain, breathing or any other chronic } \\
\text { illness or condition }\end{array}$} & $-0.010 * * *$ & $-0.012 * * *$ & $-0.070 * * *$ \\
\hline & $(0.003)$ & $(0.004)$ & $(0.022)$ \\
\hline
\end{tabular}

Source: Derived by authors using 2011 Census microdata.

Note: Working age population (15-64 years of age) in employment (employees only). Controls for gender, age, ethnicity, nationality, marital status, geographic location, and not stated cases included in the estimated specifications. Standard errors in parentheses; ${ }^{* * *} \mathrm{p}<0.01,{ }^{* *} \mathrm{p}<0.05, * \mathrm{p}<0.1$.

TABLE A.21 IMPACT OF DISABILITY ON A PERSON'S PROBABILITY OF SELF-EMPLOYMENT, WITH INDIVIDUALS WITH AN INTELLECTUAL DISABILITY EXCLUDED AND CONTROLLING FOR EDUCATIONAL ATTAINMENT: 2016 (MARGINAL EFFECTS)

\begin{tabular}{|l|c|c|}
\hline & $\begin{array}{c}\text { All Characteristics: Less } \\
\text { Educational Attainment (3) }\end{array}$ & $\begin{array}{c}\text { All Characteristics: With } \\
\text { Educational Attainment (4) }\end{array}$ \\
\hline Disability & $-0.044^{* * *}$ & $-0.043^{* * *}$ \\
\hline General Health (Ref: Very Good/Good): & $(0.002)$ & $(0.002)$ \\
\hline Fair & $-0.078^{* * *}$ & $-0.068^{* * *}$ \\
\hline Bad/Very Bad & $(0.003)$ & $(0.003)$ \\
\hline Gender (Ref: Female): & $-0.149 * * *$ & $-0.133^{* * *}$ \\
\hline Male & $(0.011)$ & $(0.011)$ \\
\hline Age (Ref: Age 35-44): & $-0.002^{*}$ & $0.006^{* * *}$ \\
\hline 15-19 & $(0.001)$ & $(0.001)$ \\
\hline 20-24 & & $-0.090^{* * *}$ \\
\hline $\mathbf{2 5 - 3 4}$ & $-0.129 * * *$ & $(0.017)$ \\
\hline
\end{tabular}


TABLE A.21 CONTD.

\begin{tabular}{|c|c|c|}
\hline & $\begin{array}{c}\text { All Characteristics: Less } \\
\text { Educational Attainment (3) }\end{array}$ & $\begin{array}{l}\text { All Characteristics: With } \\
\text { Educational Attainment (4) }\end{array}$ \\
\hline \multirow[t]{2}{*}{$45-54$} & $-0.021^{* * *}$ & $-0.017 * * *$ \\
\hline & $(0.001)$ & $(0.001)$ \\
\hline \multirow[t]{2}{*}{$55-64$} & $-0.087 * * *$ & $-0.074 * * *$ \\
\hline & $(0.002)$ & $(0.002)$ \\
\hline \multicolumn{3}{|l|}{ Ethnicity (Ref: Other): } \\
\hline \multirow[t]{2}{*}{ White } & $0.029 * * *$ & $0.026 * * *$ \\
\hline & $(0.003)$ & $(0.003)$ \\
\hline \multicolumn{3}{|c|}{ Nationality (Ref: Non-Irish): } \\
\hline \multirow[t]{2}{*}{ Irish } & $0.036 * * *$ & $0.040 * * *$ \\
\hline & $(0.002)$ & $(0.002)$ \\
\hline \multicolumn{3}{|c|}{ Marital Status (Ref: Single): } \\
\hline \multirow[t]{2}{*}{ Married } & $0.040 * * *$ & $0.038^{* * *}$ \\
\hline & $(0.001)$ & $(0.001)$ \\
\hline \multirow[t]{2}{*}{ Divorced/Separated } & $-0.015 * * *$ & $-0.015 * * *$ \\
\hline & $(0.002)$ & $(0.002)$ \\
\hline \multirow[t]{2}{*}{ Widowed } & $-0.053 * * *$ & $-0.045^{* * *}$ \\
\hline & $(0.004)$ & $(0.004)$ \\
\hline \multicolumn{3}{|c|}{ Geographic Location (Ref: Dublin): } \\
\hline \multirow[t]{2}{*}{ Border } & $-0.033 * * *$ & $-0.021 * * *$ \\
\hline & $(0.002)$ & $(0.002)$ \\
\hline \multirow[t]{2}{*}{ West } & $-0.017 * * *$ & $-0.010 * * *$ \\
\hline & $(0.002)$ & $(0.002)$ \\
\hline \multirow[t]{2}{*}{ Mid-West } & -0.001 & $0.003 * *$ \\
\hline & $(0.002)$ & $(0.002)$ \\
\hline \multirow[t]{2}{*}{ South-East } & $-0.017 * * *$ & $-0.011 * * *$ \\
\hline & $(0.002)$ & $(0.002)$ \\
\hline \multirow[t]{2}{*}{ South-West } & 0.001 & $0.005^{* * *}$ \\
\hline & $(0.001)$ & $(0.001)$ \\
\hline \multirow[t]{2}{*}{ Mid-East } & $-0.007 * * *$ & $-0.003^{*}$ \\
\hline & $(0.002)$ & $(0.001)$ \\
\hline \multirow[t]{2}{*}{ Midland } & $-0.011 * * *$ & $-0.004^{*}$ \\
\hline & $(0.002)$ & $(0.002)$ \\
\hline \multicolumn{3}{|c|}{ Educational Attainment (Ref: Third-Level): } \\
\hline \multirow[t]{2}{*}{ Primary or lower } & & $-0.087 * * *$ \\
\hline & & $(0.003)$ \\
\hline \multirow[t]{2}{*}{ Lower secondary } & & $-0.044 * * *$ \\
\hline & & $(0.002)$ \\
\hline \multirow[t]{2}{*}{ Upper secondary } & & $-0.024 * * *$ \\
\hline & & $(0.001)$ \\
\hline Observations & 301,917 & 301,917 \\
\hline Pseudo R-squared & 0.0817 & 0.0943 \\
\hline
\end{tabular}

Source: Derived by authors using 2016 Census microdata.

Note: $\quad$ Working age population (15-64 years of age) in employment (self-employed only). 'Not stated' cases controlled for in estimated specifications. 'Ref' = reference category (i.e. the group against which the derived results are compared with). Standard errors in parentheses; ${ }^{* * *} p<0.01,{ }^{* *} p<0.05,{ }^{*} p<0.1$. 
TABLE A.22 IMPACT OF DISABILITY TYPE ON A PERSON'S PROBABILITY OF SELFEMPLOYMENT, WITH INDIVIDUALS WITH AN INTELLECTUAL DISABILITY EXCLUDED AND CONTROLLING FOR EDUCATIONAL ATTAINMENT: 2016 (MARGINAL EFFECTS)

\begin{tabular}{|c|c|c|}
\hline & $\begin{array}{l}\text { All Characteristics: } \\
\text { Less Educational } \\
\text { Attainment } \\
\text { (3) }\end{array}$ & $\begin{array}{l}\text { All Characteristics: } \\
\text { With Educational } \\
\text { Attainment } \\
\text { (4) }\end{array}$ \\
\hline \multicolumn{3}{|l|}{ Disability Type: } \\
\hline \multirow[t]{2}{*}{ Blindness or a serious vision impairment } & $-0.030 * * *$ & $-0.029 * * *$ \\
\hline & $(0.007)$ & $(0.007)$ \\
\hline \multirow[t]{2}{*}{ Deafness or a serious hearing impairment } & $-0.017^{* * *}$ & $-0.015^{* * *}$ \\
\hline & $(0.004)$ & $(0.004)$ \\
\hline \multirow[t]{2}{*}{$\begin{array}{l}\text { Difficulty with basic physical activities such as walking, } \\
\text { climbing stairs, reaching, lifting or carrying }\end{array}$} & $-0.070 * * *$ & $-0.065^{* * *}$ \\
\hline & $(0.005)$ & $(0.005)$ \\
\hline \multirow[t]{2}{*}{ Difficulty in learning, remembering or concentrating } & $-0.045^{* * *}$ & $-0.034 * * *$ \\
\hline & $(0.006)$ & $(0.005)$ \\
\hline \multirow[t]{2}{*}{ Psychological or emotional condition } & $-0.061 * * *$ & $-0.065^{* * *}$ \\
\hline & $(0.006)$ & $(0.006)$ \\
\hline \multirow[t]{2}{*}{$\begin{array}{l}\text { Difficulty with pain, breathing or any other chronic illness } \\
\text { or condition }\end{array}$} & $-0.005^{* *}$ & $-0.008 * * *$ \\
\hline & $(0.002)$ & $(0.002)$ \\
\hline \multicolumn{3}{|l|}{ General Health (Ref: Very Good/Good): } \\
\hline \multirow[t]{2}{*}{ Fair } & $-0.075^{* * *}$ & $-0.066 * * *$ \\
\hline & $(0.003)$ & $(0.003)$ \\
\hline \multirow[t]{2}{*}{ Bad/Very Bad } & $-0.121 * * *$ & $-0.107^{* * *}$ \\
\hline & $(0.011)$ & $(0.010)$ \\
\hline \multicolumn{3}{|l|}{ Gender (Ref: Female): } \\
\hline \multirow[t]{2}{*}{ Male } & $-0.002 *$ & $0.006 * * *$ \\
\hline & $(0.001)$ & $(0.001)$ \\
\hline \multicolumn{3}{|l|}{ Age (Ref: Age 35-44): } \\
\hline \multirow[t]{2}{*}{$15-19$} & $-0.126 * * *$ & $-0.089 * * *$ \\
\hline & $(0.019)$ & $(0.017)$ \\
\hline \multirow[t]{2}{*}{$20-24$} & $-0.014 * * *$ & $-0.011^{* *}$ \\
\hline & $(0.005)$ & $(0.005)$ \\
\hline \multirow[t]{2}{*}{$25-34$} & $0.007^{* * *}$ & $0.006 * * *$ \\
\hline & $(0.002)$ & $(0.002)$ \\
\hline \multirow[t]{2}{*}{$45-54$} & $-0.021 * * *$ & $-0.017 * * *$ \\
\hline & $(0.001)$ & $(0.001)$ \\
\hline \multirow[t]{2}{*}{$55-64$} & $-0.087 * * *$ & $-0.074 * * *$ \\
\hline & $(0.002)$ & $(0.002)$ \\
\hline \multicolumn{3}{|l|}{ Ethnicity (Ref: Other): } \\
\hline \multirow[t]{2}{*}{ White } & $0.029 * * *$ & $0.026^{* * *}$ \\
\hline & $(0.003)$ & $(0.003)$ \\
\hline \multicolumn{3}{|l|}{ Nationality (Ref: Non-Irish): } \\
\hline \multirow[t]{2}{*}{ Irish } & $0.036 * * *$ & $0.040 * * *$ \\
\hline & $(0.002)$ & $(0.002)$ \\
\hline
\end{tabular}


TABLE A.22 CONTD.

\begin{tabular}{|c|c|c|}
\hline & $\begin{array}{l}\text { All Characteristics: } \\
\text { Less Educational } \\
\text { Attainment } \\
\text { (3) }\end{array}$ & $\begin{array}{l}\text { All Characteristics: } \\
\text { With Educational } \\
\text { Attainment } \\
\text { (4) }\end{array}$ \\
\hline \multicolumn{3}{|c|}{ Marital Status (Ref: Single): } \\
\hline \multirow[t]{2}{*}{ Married } & $0.039 * * *$ & $0.037 * * *$ \\
\hline & $(0.001)$ & $(0.001)$ \\
\hline \multirow[t]{2}{*}{ Divorced/Separated } & $-0.015^{* * *}$ & $-0.015^{* * *}$ \\
\hline & $(0.002)$ & $(0.002)$ \\
\hline \multirow[t]{2}{*}{ Widowed } & $-0.052 * * *$ & $-0.045^{* * *}$ \\
\hline & $(0.004)$ & $(0.004)$ \\
\hline \multicolumn{3}{|c|}{ Geographic Location (Ref: Dublin): } \\
\hline \multirow[t]{2}{*}{ Border } & $-0.032 * * *$ & $-0.021 * * *$ \\
\hline & $(0.002)$ & $(0.002)$ \\
\hline \multirow[t]{2}{*}{ West } & $-0.017 * * *$ & $-0.010 * * *$ \\
\hline & $(0.002)$ & $(0.002)$ \\
\hline \multirow[t]{2}{*}{ Mid-West } & -0.001 & $0.003^{* *}$ \\
\hline & $(0.002)$ & $(0.002)$ \\
\hline \multirow[t]{2}{*}{ South-East } & $-0.017^{* * *}$ & $-0.011 * * *$ \\
\hline & $(0.002)$ & $(0.002)$ \\
\hline \multirow[t]{2}{*}{ South-West } & 0.001 & $0.005^{* * *}$ \\
\hline & $(0.001)$ & $(0.001)$ \\
\hline \multirow[t]{2}{*}{ Mid-East } & $-0.007^{* * *}$ & $-0.003^{*}$ \\
\hline & $(0.002)$ & $(0.001)$ \\
\hline \multirow[t]{2}{*}{ Midland } & $-0.011 * * *$ & $-0.004^{*}$ \\
\hline & $(0.002)$ & $(0.002)$ \\
\hline \multicolumn{3}{|c|}{ Educational Attainment (Ref: Third-Level): } \\
\hline \multirow[t]{2}{*}{ Primary or lower } & & $-0.086 * * *$ \\
\hline & & $(0.003)$ \\
\hline \multirow[t]{2}{*}{ Lower secondary } & & $-0.044 * * *$ \\
\hline & & $(0.002)$ \\
\hline \multirow[t]{2}{*}{ Upper secondary } & & $-0.024 * * *$ \\
\hline & & $(0.001)$ \\
\hline Observations & 301,917 & 301,917 \\
\hline Pseudo R-squared & 0.0838 & 0.0961 \\
\hline
\end{tabular}

Source: Derived by authors using 2016 Census microdata.

Note: $\quad$ Working age population (15-64 years of age) in employment (self-employed only). 'Not stated' cases controlled for in estimated specifications. 'Ref' = reference category (i.e. the group against which the derived results are compared with). Standard errors in parentheses; ${ }^{* * *} p<0.01,{ }^{* *} p<0.05,{ }^{*} p<0.1$. 
TABLE A.23 COUNTRY ABBREVIATIONS IN EU-SILC

\begin{tabular}{|c|c|}
\hline Country abbreviation & Country name \\
\hline AT & Austria \\
\hline BE & Belgium \\
\hline BG & Bulgaria \\
\hline $\mathrm{CY}$ & Cyprus \\
\hline CZ & Czech Republic \\
\hline DE & Germany \\
\hline DK & Denmark \\
\hline EE & Estonia \\
\hline EL & Greece \\
\hline ES & Spain \\
\hline FI & Finland \\
\hline FR & France \\
\hline HR & Croatia \\
\hline HU & Hungary \\
\hline IE & Ireland \\
\hline IT & Italy \\
\hline LT & Lithuania \\
\hline LU & Luxembourg \\
\hline LV & Latvia \\
\hline MT & Malta \\
\hline NL & The Netherlands \\
\hline PL & Poland \\
\hline PT & Portugal \\
\hline RO & Romania \\
\hline SE & Sweden \\
\hline SI & Slovenia \\
\hline SK & Slovakia \\
\hline UK & United Kingdom \\
\hline
\end{tabular}


Whitaker Square,

Sir John Rogerson's Quay,

Dublin 2

Telephone +35318632000

Email admin@esri.ie

Web www.esri.ie

Twitter @ESRIDublin 